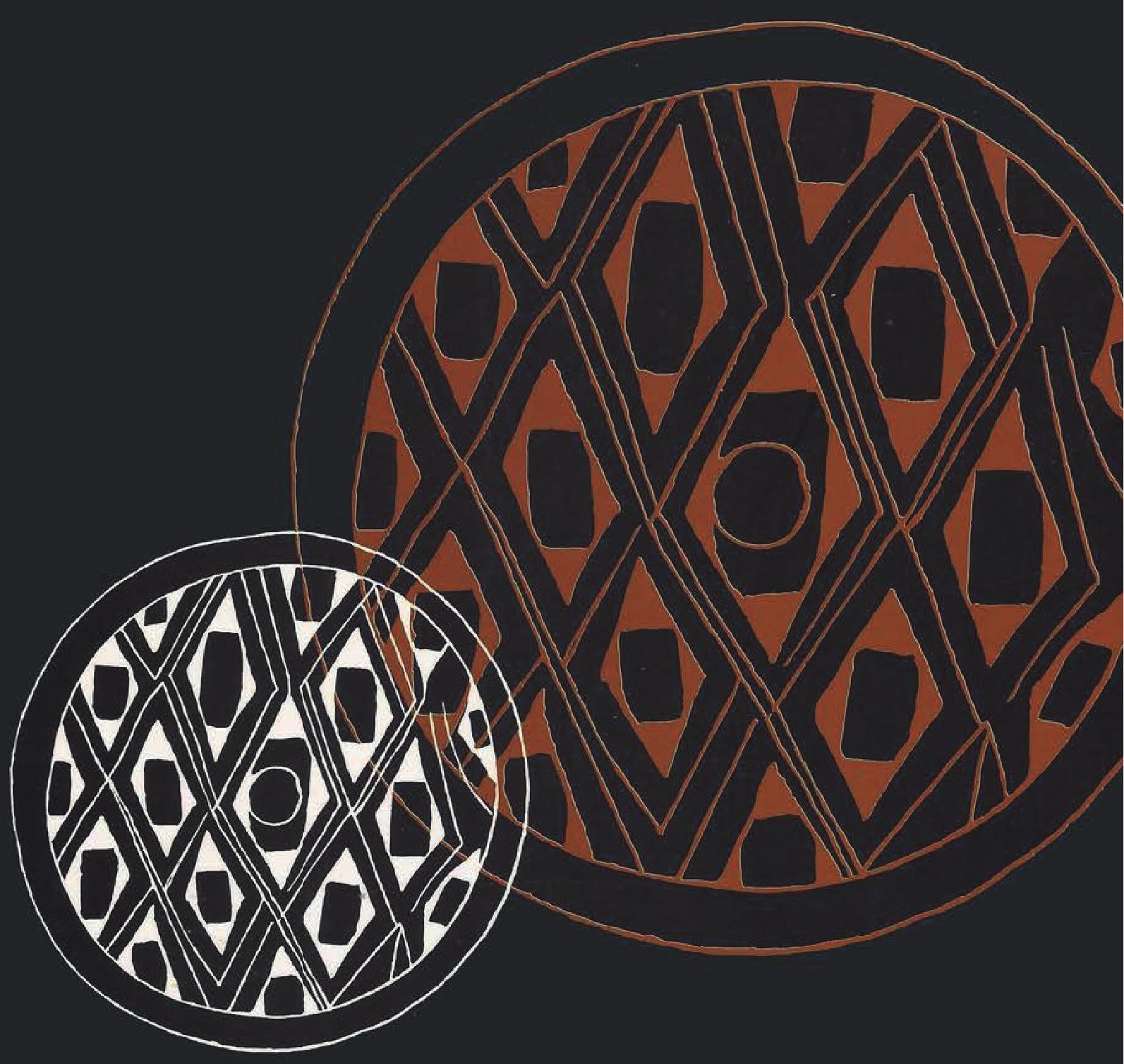

Demografia dos
Povos Indigenas no Brasil

Heloísa Pagliaro

Marta Maria Azevedo

Ricardo Ventura Santos

organizadores

cbep 


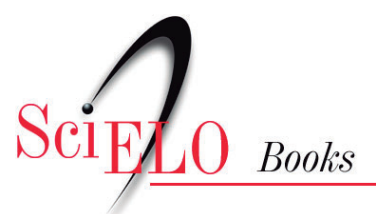

\title{
Demografia dos povos indígenas no Brasil
}

\author{
Heloísa Pagliaro \\ Marta Maria Azevedo \\ Ricardo Ventura Santos \\ (orgs.)
}

PAGLIARO, H., AZEVEDO, MM., and SANTOS, RV., comps. Demografia dos povos indígenas no Brasil [online]. Rio de Janeiro: Editora FIOCRUZ, 2005. 192 p. Saúde dos Povos Índigenas collection. ISBN: 978-85-7541-254-1. https://doi.org/10.7476/9788575412541.

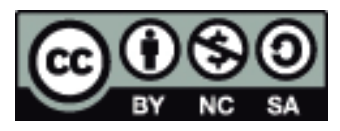

All the contents of this work, except where otherwise noted, is licensed under a Creative Commons Attribution-Non Commercial-ShareAlike 3.0 Unported.

Todo o conteúdo deste trabalho, exceto quando houver ressalva, é publicado sob a licença Creative Commons Atribuição - Uso Não Comercial - Partilha nos Mesmos Termos 3.0 Não adaptada.

Todo el contenido de esta obra, excepto donde se indique lo contrario, está bajo licencia de la licencia Creative Commons Reconocimento-NoComercial-Compartirlgual 3.0 Unported. 

Demografia dos Povos Indígenas no Brasil 


\section{FUNDAÇÃO OSWALDO CRUZ \\ Presidente \\ Paulo Marchiori Buss}

Vice-Presidente de Ensino, Informação e Comunicação

Maria do Carmo Leal

\section{EDITORA FIOCRUZ}

Coordenadora

Maria do Carmo Leal

Conselho Editorial

Carla Macedo Martins

Carlos E. A. Coimbra Jr.

Charles Pessanha

Gilberto Hochman

Jaime L. Benchimol

José da Rocha Carvalheiro

José Rodrigues Coura

Luis David Castiel

Luiz Fernando Ferreira

Maria Cecília de Souza Minayo

Miriam Struchiner

Paulo Amarante

Paulo Gadelha

Vanize Macêdo

Coordenador Executivo

João Carlos Canossa P. Mendes

Coleção Saúde dos Povos Indígenas

Editores Responsáveis: Ricardo Ventura Santos

Carlos E. A. Coimbra Jr. 


\section{Demografia dos Povos Indígenas no Brasil}

Heloísa Pagliaro Marta Maria Azevedo

Ricardo Ventura Santos organizadores 
Copyright (c) 2005 dos autores

Todos os direitos desta edição reservados à

FUNDAÇÃO OSWALDO CRUZ/ EDITORA FIOCRUZ E ASSOCIAÇÃO BRASILEIRA DE ESTUDOS POPULACIONAIS (ABEP)

ISBN: 85-7541-056-3

Capa

Danowski Design

Ilustração de capa

Tortual dos mehinakú com motivos mereschu, do livro de Karl von den Steinen Entre os Aborígenes do Brasil Central, Departamento de Cultura, São Paulo, 1940

Projeto gráfico e editoração eletrônica Angélica Mello e Daniel Pose Vazquez

Preparação de originais, copidesque e revisão

Jorge Luís Ferreira Martins Correa

Revisão final

Marcionílio Cavalcanti de Paiva

Esta publicação foi possível através de apoio do Fundo de População das Nações Unidas (Fnuap), concedido através da Associação Brasileira de Estudos Populacionais (Abep), e da Fundação Ford, por meio do projeto Saúde Indígena em Rondônia (convênio Centro de Estudos em Saúde do Índio de Rondônia - Cesir - Universidade Federal de Rondônia/Escola das Nações Unidas

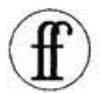

Fundaçāo Ford Nacional de Saúde Pública - Fundação Oswaldo Cruz).

Catalogação-na-fonte

Centro de Informação Científica e Tecnológica

Biblioteca da Escola Nacional de Saúde Pública Sergio Arouca

P138d Pagliaro, Heloísa (org.)

Demografia dos Povos Indígenas no Brasil/Heloísa Pagliaro, Marta Maria Azevedo e Ricardo Ventura Santos (Orgs.). Rio de Janeiro: Editora Fiocruz e Associação Brasileira de Estudos Populacionais/Abep, 2005.

192p., tab., gráf., mapas

1.Índios sul-americanos. 2.Demografia. I.Azevedo, Marta Maria (org.). II.Santos, Ricardo Ventura (org.). III.Título.

CDD - 20.ed. -980.41

2005

EDITORA FIOCRUZ

Av. Brasil, $4036-1^{\circ}$ andar - sala 112 - Manguinhos

21040-361 - Rio de Janeiro - RJ

Tels.: (21) 3882-9039 e 3882-9041/ Telefax: (21) 3882-9006

e-mail: editora@fiocruz.br

http://www.fiocruz.br/editora

ASSOCIAÇĀO BRASILEIRA DE ESTUDOS POPULACIONAIS - ABEP

Caixa postal 6166 - 13083-970 - Campinas - SP

Tels: (19) 3788-5910/Fax: (19) 3788-5900

e-mail: secretaria@abep.org.br

http//:www.abep.org

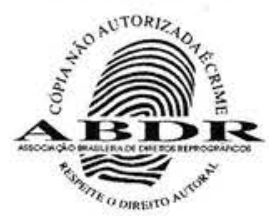


Autores

Candido Procópio Ferreira de Camargo foi professor na Escola de Sociologia e Política de São Paulo. Em 1966 criou o Centro de Estudos de Dinâmica Populacional (Cedip), do qual foi presidente. Em 1970 tornou-se professor da Universidade de São Paulo. Foi fundador e diretor-presidente do Centro Brasileiro de Análise e Planejamento (Cebrap).

Carlos E. A. Coimbra Jr. é biólogo e Ph.D. em Antropologia pela Indiana University (EUA). É professor na Escola Nacional de Saúde Pública Sergio Arouca da Fundação Oswaldo Cruz, Rio de Janeiro. Desenvolve pesquisas sobre saúde dos povos indígenas na Amazônia desde a década de 1980, particularmente em Mato Grosso e Rondônia, com os Tupí-Mondé e os Xavánte.

Carmen Junqueira é doutora em Antropologia pela Unicamp e professora titular e emérita do Depto. de Antropologia da Faculdade de Ciências Sociais da Pontifícia Universidade Católica de São Paulo (PUC-SP). Estudou povos indígenas dos estados de São Paulo, Acre, Rondônia e Mato Grosso. Pesquisa os Kamaiurá, do Parque do Xingu, desde 1965.

Heloísa Pagliaro (Organizadora) é socióloga e demógrafa, com doutorado em Saúde Pública pela Universidade de São Paulo (USP). Ensina Demografia no Programa de Pós-Graduação em Epidemiologia da Universidade Federal de São Paulo (Unifesp). Desenvolve pesquisa demográfica junto a povos indígenas desde 1992.

John Early é professor aposentado do Departamento de Antropologia da Florida Atlantic University, Flórida (EUA). Obteve seu Ph.D. pela Harvard University, tendo realizado pesquisas sobre os Maias no México. Posteriormente desenvolveu pesquisas demográficas sobre os Maias na Guatemala, sobre os Yanomami no Brasil e sobre os Agta nas Filipinas. 
Marília Brasil é economista, com mestrado em Demografia pelo Centro de Desenvolvimento e Planejamento Regional (Cedeplar/UFMG). Trabalhou na Fundação Joaquim Nabuco e também na Universidade Federal do Amazonas (Ufam). Atualmente é pesquisadora visitante no Centro de Pesquisa Leônidas G Maria Deane da Fundação Oswaldo Cruz (Manaus).

Marta Maria Azevedo (Organizadora) é antropóloga com doutorado em Demografia pela Universidade Estadual de Campinas (Unicamp). Trabalhou com os Guarani / Kaiowá do Mato Grosso do Sul. Atualmente desenvolve pesquisas sobre nupcialidade e fecundidade com os povos indígenas no Rio Negro/AM. É coordenadora de projetos no Instituto Socioambiental (ISA).

Nancy May Flowers é antropóloga, tendo obtido seu doutorado pela City University of New York (Cuny). Desenvolve pesquisas em Antropologia, Ecologia Humana e Demografia com os Xavánte desde a década de 1970. Leciona no Hunter College da City University of New York, nos Estados Unidos.

Nilza de Oliveira Martins Pereira é estatística, com pós-graduação em Demografia e Educação. É pesquisadora do Instituto Brasileiro de Geografia e Estatística (IBGE). Atualmente exerce o cargo de Gerente de Análises Estruturais e Espaciais da População da Coordenação de População e Indicadores Sociais do IBGE.

Paulo Campanário é cientista social e Ph.D. em Demografia na Universidade de Montreal, Canadá. Trabalhou no Centro Latinoamericano de Demografia (Celade-Costa Rica), no Inec (Nicarágua), na UFPB (Campina Grande), no Fnuap (Angola, Moçambique e São Tomé e Príncipe), na Fundação Seade e no IMS/Uerj. Atualmente, atua como consultor no campo da demografia.

Pery Teixeira é matemático, com doutorado em Demografia pelo Centro de Desenvolvimento e Planejamento Regional (Cedeplar/UFMG). É professor da Universidade Federal do Amazonas. Anteriormente trabalhou na Fundação Joaquim Nabuco, no Fundo de População das Nações Unidas - Fnuap (Angola) e no Unicef (Angola).

Ricardo Ventura Santos (Organizador) é biólogo e Ph.D. em Antropologia Biológica pela Indiana University, EUA. Trabalha com saúde e demografia de povos indígenas, particularmente em Rondônia e Mato Grosso. É professor do Departamento de Antropologia do Museu Nacional/UFRJ e pesquisador da Escola Nacional de Saúde Pública Sergio Arouca, Fundação Oswaldo Cruz, Rio de Janeiro. 
1. Demografia dos Povos Indígenas no Brasil: um panorama crítico Heloísa Pagliaro, Marta Maria Azevedo e Ricardo Ventura Santos

2. Povos Indígenas no Alto Rio Negro: um estudo de caso de nupcialidade 33 Marta Maria Azevedo

3. Demografia, Epidemias e Organização Social: os Xavánte de Pimentel Barbosa (Etéñitépa), Mato Grosso 59 Ricardo Ventura Santos, Nancy M. Flowers e Carlos E.A. Coimbra Jr.

4. A Revolução Demográfica dos Povos Indígenas: a experiência dos Kaiabi do Parque Indígena do Xingu, Mato Grosso 79 Heloísa Pagliaro

5. Estimativas de Fecundidade e de Mortalidade de Populações de Pequena Escala Através de um Modelo Demográfico 103 Paulo Campanário

6. Reflexões Acerca do Mundo Cultural e do Comportamento Reprodutivo dos Kamaiurá Ontem e Hoje 119 Cândido Procópio F. de Camargo, Carmen Junqueira e Heloísa Pagliaro

7. Estudo Demográfico dos Sateré-Mawé: um exemplo de censo participativo .135 Pery Teixeira e Marília Brasil 
8. Perfil Demográfico e Socioeconômico das Pessoas que se Autodeclararam 'Indígenas' nos Censos Demográficos de 1991 e 2000 155 Nilza de Oliveira M. Pereira, Ricardo Ventura Santos e Marta Maria Azevedo

9. A Dinâmica Demográfica dos Mucajaí Yanomami: uma entrevista com John Early 167 Ricardo Ventura Santos, Heloísa Pagliaro e Marta Maria Azevedo 
Apresentação

Este volume é o resultado do esforço do Comitê de Demografia dos Povos Indígenas da Associação Brasileira de Estudos Populacionais (Abep) na direção da ampliação e articulação de estudos que permitam avançar no conhecimento da dinâmica demográfica indígena e suas implicações.

Como apontam Heloísa Pagliaro, Marta Maria Azevedo e Ricardo Ventura Santos, os organizadores de Demografia dos Povos Indígenas no Brasil, é de certo modo surpreendente que, apesar da centralidade dos fenômenos e processos vitais nas disciplinas antropológica e demográfica, estes processos tenham sido objeto de reduzido esforço e cooperação interdisciplinar no que diz respeito a povos indígenas no Brasil.

O Comitê de Demografia dos Povos Indígenas da Abep, reunindo especialistas de distintas áreas, é mais um passo no sentido de superar obstáculos e preencher lacunas no conhecimento das sociedades indígenas. A precariedade e dispersão das informações disponíveis, a importância de dados consistentes para a realização de diagnósticos adequados acerca das necessidades dessas populações e a potencialidade da colaboração interdisciplinar para o entendimento da dinâmica social indígena, são aspectos a destacar nas contribuições reunidas neste volume.

A expectativa da Abep é a de que os trabalhos aqui trazidos a público possam contribuir para um aprofundamento do debate acerca da questão indígena, reafirmando o caráter plural da sociedade brasileira.

Maria Coleta A. Ferreira de Oliveira Núcleo de Estudos de População Universidade Estadual de Campinas 



\section{Demografia dos Povos Indígenas no Brasil: um panorama crítico}

\section{Introdução}

São ainda muito pouco conhecidas as mais diversas dimensões da dinâmica demográfica - seja natalidade, mortalidade ou migração - dos povos indígenas no Brasil contemporâneo. Se essa assertiva se aplica plenamente ao conjunto dos povos indígenas, torna-se ainda mais contundente em face da diversidade dessas sociedades. São mais de 200 povos, falantes de aproximadamente 180 línguas, distribuídos em praticamente todo o território nacional, em áreas rurais e urbanas, com características sociais e culturais, bem como com trajetórias históricas, econômicas e políticas, as mais diversas. Quanto à população total dos povos indígenas no país, a depender da fonte, soma entre 350 e 715 mil pessoas, mas não ultrapassando $0,5 \%$ da população nacional. ${ }^{1}$ Como é bem conhecida, a dinâmica demográfica de uma dada população resulta da confluência de uma multiplicidade de fatores históricos, antropológicos, sociais e econômicos. Assim sendo, em vista da sociodiversidade indígena no país, ao se abordar a demografia desses povos, menos que refletir no singular, devemos nos pautar em dimensões plurais.

Duas décadas atrás, por ocasião do IV Encontro da Associação Brasileira de Estudos Populacionais (Abep), que aconteceu em Águas de São Pedro (SP), foi realizada uma sessão na qual foram apresentados trabalhos relativos à demografia dos povos indígenas. Na ocasião, observou-se que:

O conhecimento do contingente, estrutura e dinâmica populacional dos diversos povos indígenas no Brasil fornecerá, a curto prazo, base [de informações] para projetos econômicos, educacionais e de assistência médica, além de, por meio de projeções, prever problemas futuros, viabilizando a adoção de medidas preventivas. Para tanto, surge a necessidade da existência de censos populacionais indígenas regulares e um sistema de registro atualizados. ...[Sabe-se] que a carência de estatísticas de populações indígenas é preocupante. Os dados existentes, geralmente, não vão além de simples contagens de indivíduos; portanto, maiores inferências quanto às dinâmicas destas populações. Exceto 
alguns trabalhos de pesquisadores... inexiste qualquer tentativa de medir níveis de fecundidade, mortalidade, movimentos migratórios etc. (...) (Penna, 1984)

Passados vinte anos, a situação dos povos indígenas modificou-se em muitos aspectos. Desse modo, houve um fortalecimento do movimento indígena e maior visibilidade política da questão indígena nas últimas décadas. Além disso, no plano demográfico, ficou evidente que, ao invés de uma tendência de descenso, sua população total vem crescendo em ritmo pronunciado, superando inclusive as médias nacionais. ${ }^{2}$ Foram também implementadas iniciativas de coleta e sistematização de dados demográficos sobre os povos indígenas no país, destacandose a inclusão da categoria 'indígena' na variável cor ou raça do censo decenal, a partir de 1991, e a estruturação de um sistema de informação sobre saúde indígena de abrangência nacional, a partir de 1999, que envolve um componente demográfico. Não menos importante, nos últimos anos, é que antropólogos e demógrafos vêm realizando em crescente número pesquisas de campo em comunidades indígenas, o que tem gerado um acervo de estudos de caso de grande relevância para o conhecimento acerca da diversidade de experiências demográficas desses povos. Conhecimentos gerados por essas várias iniciativas podem prover subsídios importantes para o planejamento, implementação e monitoramento de políticas públicas nas áreas de educação, saúde, etnodesenvolvimento, entre outras, bem como trazer novas reflexões para o campo da demografia propriamente dita.

Como reflexo desse cenário, as contribuições desta coletânea apontam para a vitalidade que a demografia dos povos indígenas alcançou nos últimos anos. Foi concebida de modo a retratar a diversidade de abordagens teóricas e metodológicas que as pesquisas sobre o comportamento demográfico dos povos indígenas apresentam no presente, tanto quanto fornecer uma síntese do estado atual do conhecimento sobre o tema. Por certo, como diagnosticado duas décadas atrás, ainda se está muito distante de um conhecimento suficientemente detalhado do comportamento demográfico dos povos indígenas. Contudo, é inegável que atualmente dispomos de um volume de informações, de uma variedade de abordagens e de um aprimoramento teórico-metodológico de que não se dispunha até um passado recente.

\section{Demografia antropológica e os povos indígenas no Brasil}

Poderíamos apontar diversas razões para o pouco desenvolvimento da área da demografia dos povos indígenas no Brasil até recentemente. Por um lado, a antropologia no Brasil, com larga tradição de estudos em sociedades indígenas, é de ênfase eminentemente qualitativa, com os etnólogos pouco familiarizados e treinados em métodos quantitativos. Logo, mesmo que temas como nascimento, 
estágio e ciclo de vida, morte, regras de casamento e mobilidade, entre outros, todos de grande interesse para a demografia, sejam rotineiramente abordados nas etnografias, em larga medida não são tratados com a dimensão quantitativa demandada pelas análises conduzidas por demógrafos. Por outro lado, a temática indígena nunca chegou a se constituir em questão de interesse específico da comunidade de demógrafos no país.

Se particularidades disciplinares influenciaram a consolidação do campo de pesquisa da demografia indígena, há um aspecto mais geral que deve ser destacado, qual seja, a dificuldade enfrentada para realizar os estudos propriamente ditos, centrada fundamentalmente na obtenção e no tratamento dos dados. Sem pretender elaborar uma lista exaustiva, vale chamar a atenção para algumas dificuldades mais comuns.

Por exemplo, para a quase totalidade das comunidades indígenas, com raríssimas exceções, não há séries históricas documentadas de nascimentos, óbitos e eventos de migração. Uma alternativa que tem sido implementada é a de realizar pesquisas em profundidade, entrevistando os indivíduos de modo a recuperar os eventos demográficos. Porém, além do tempo necessário para tal abordagem e a pouca profundidade temporal possível de ser recuperada, há a questão de que as linguagens matemáticas dos povos indígenas ainda são pouco pesquisadas e desconhecidas dos antropólogos e demógrafos, situação que dificulta a comunicação entre o nosso sistema numérico e a enorme variedade de sistemas numéricos desses povos. Além disso, cada povo indígena possui sua própria maneira de classificar a idade das pessoas. Acrescentem-se ainda as proscrições quanto a falar sobre os mortos presentes em várias culturas, fato que dificulta a realização de entrevistas acerca da mortalidade, fecundidade e outros eventos demográficos. Por fim, sem exaurir a pauta das questões metodológicas, há dificuldades no cálculo e na interpretação dos indicadores demográficos ante o reduzido contingente populacional dos povos indígenas. Ao serem analisadas as séries históricas, por exemplo, nem sempre é discernível se as variações observadas derivam de mudanças efetivas no comportamento demográfico ou se são decorrentes de variações aleatórias em virtude dos pequenos números presentes nos numeradores e denominadores.

A qualidade das fontes de dados sobre os povos indígenas, que sempre foram muito precárias, traduz uma dificuldade ímpar para fins dos estudos demográficos. Além dos históricos recenseamentos pouco confiáveis dos governos provinciais, censos periódicos e registros de eventos vitais do Serviço de Proteção aos Índios (SPI), conta-se com dados sobre algumas populações, levantadas pela Fundação Nacional do Índio (Funai). Essas informações podiam oscilar, ao longo do tempo, de acordo com os interesses políticos dos governos provinciais e do SPI/Funai e de acordo com a existência de postos indígenas em diferentes regiões 
do Brasil. ${ }^{3}$ Nos Postos Indígenas mais antigos, como aqueles criados entre as décadas de 1930 e 1960, verificava-se a prática de preencher os livros oficiais de certidão de nascimento, casamento e óbito. Para algumas regiões e povos, esses registros são de grande relevância; todavia, nem todos os eventos demográficos eram registrados e parte deles o foram tardiamente. A Funai tem feito levantamentos populacionais parciais, segundo suas administrações regionais, que alimentam um banco de dados com informações sobre população total por aldeia/comunidade, etnia e Terra Indígena.

Quanto aos recenseamentos periódicos, o primeiro censo nacional que levantou informações sobre as populações indígenas foi o de 1991, que incluiu a categoria indígena na variável 'cor ou raça'. ${ }^{4} \mathrm{Na}$ ocasião, foram recenseados somente índios moradores de missões religiosas, postos indígenas da Funai ou áreas urbanas, ignorando um grande contingente de indígenas que habitavam áreas onde o órgão não mantinha, até aquele ano, postos instalados (Azevedo, 1994). Já o censo de 2000 teve uma cobertura maior, estendendo-se a todas as Terras Indígenas do país, bem como às demais áreas rurais e urbanas, deixando, no entanto, de levantar a filiação étnica específica dos indivíduos recenseados. ${ }^{5}$

Mais recentemente, com a transferência da política de assistência à saúde dos povos indígenas da Funai para a Fundação Nacional de Saúde (Funasa), que ocorreu em 1999, foram implantados os chamados Distritos Sanitários Especiais Indígenas (DSEI). No presente, são 34 DSEI, distribuídos nas diversas regiões do país. Com o intuito de subsidiar o subsistema de atenção à saúde indígena com informações demográficas, epidemiológicas e de utilização de serviços, foi criado o Sistema de Informação da Atenção à Saúde Indígena (Siasi). Infelizmente, o Siasi não vem gerando e disponibilizando de forma ampla os dados produzidos pelos DSEI, de modo que a caracterização do perfil demográfico dos povos indígenas com base nessa fonte está aquém do que seria esperado em face dos investimentos direcionados para a criação desse sistema de informação (ver Garnelo, Macedo G Brandão, 2003; Santos G Coimbra Jr., 2003).

Além das fontes de dados oficiais, podem ser mencionadas várias iniciativas de sistematização de dados demográficos por parte de instituições religiosas, de saúde e organizações não-governamentais e organizações de povos indígenas existentes atualmente.

Levantamentos realizados em comunidades específicas por antropólogos durante trabalhos de campo, em determinado ano ou período de tempo, continuam sendo fontes importantes de dados demográficos. Nesse âmbito, vale frisar a iniciativa do antigo 'Programa Povos Indígenas' do Centro Ecumênico de Documentação e Informação (Cedi), incorporado pelo Instituto Socioambiental (ISA), que desde a década de 1980 cataloga e disponibiliza dados sobre tamanho populacional de povos indígenas nas Terras Indígenas. As publicações mais 
recentes nessa linha são Povos Indígenas no Brasil 1991/1995 e Povos Indígenas no Brasil 1996/2000, ambas com quadros que compilam estimativas de população segundo povo e terra indígena (Ricardo, 1996, 2000). Ainda que os dados ali apresentados não possibilitem análises mais detalhadas (geralmente não havia sequer informação de composição por sexo e idade), sempre tiveram grande relevância perante a carência de informações, por muito tempo constituindo quase que a totalidade do que se conhecia sobre a população dos povos indígenas no país.

O programa de atenção à saúde dos povos do Parque Indígena do Xingu (PIX) da Escola Paulista de Medicina (EPM), atual Universidade Federal de São Paulo (Unifesp), que teve início em 1966 e se estende até o presente, instituiu uma ficha médica com o registro de dados do exame clínico ao lado de informações demográficas e de elementos que permitem tanto a identificação individual, quanto familiar e étnica do indivíduo examinado. A alimentação contínua desse sistema de informações e a sua cobertura ao universo dos povos do PIX asseguram o acompanhamento demográfico e epidemiológico efetivo dessas populações ao longo de um período de 38 anos, propiciando, inclusive, a oportunidade de realizar estudos longitudinais, pouco freqüentes no Brasil (Baruzzi, Marcopito G Iunes, 1978). Recentemente, a introdução dessas fichas num banco de dados, contendo arquivos por povo, aldeia e família, facilitou não apenas a alimentação do sistema, como a realização de pesquisas (ver Pagliaro, neste volume e Junqueira et al., neste volume).

Outra iniciativa foi aquela da Federação das Organizações Indígenas do Rio Negro (Foirn), criada em 1986, que realizou em 1992 um recenseamento das populações da região, em conjunto com associações indígenas filiadas (Azevedo, 1994). Este censo foi feito com o objetivo de complementar um laudo antropológico que estava sendo realizado nessa época com o fito de apoiar os esforços pela demarcação das terras indígenas da região do alto rio Negro.

Mais recentemente, uma parceria entre as organizações indígenas SateréMawé, o Instituto de Estudos sobre a Amazônia da Fundação Joaquim Nabuco do Amazonas, a Universidade Federal do Amazonas (Ufam), o Fundo das Nações Unidas para a Infância (Unicef), o Fundo de População das Nações Unidas (Fnuap), a Funai, a Funasa e outras instituições regionais realizou, no ano de 2003, um diagnóstico sociodemográfico da população Sateré-Mawé das áreas indígenas Andirá-Marau e Koatá-Laranjal, e das áreas urbanas de Parintins, Barreirinha, Maués e Nova Olinda do Norte, registrando 8.378 indivíduos (Teixeira G Brasil, neste volume).

Esses censos, realizados com as populações do rio Negro e Sateré-Mawé, respectivamente, contaram com a participação ativa dos povos envolvidos, no pressuposto de que a formulação, a coleta e a apropriação de seus resultados 
constituem dimensões importantes para os povos indígenas refletirem sobre sua situação atual e pensarem seus projetos de futuro.

\section{Demografia dos povos indígenas no Brasil}

Sem pretender realizar uma revisão exaustiva da literatura, mencionamse a seguir alguns estudos que contemplaram análises demográficas de sociedades indígenas no Brasil ou que relacionaram aspectos demográficos a dimensões de suas culturas.

Uma temática que desde longa data vem atraindo a atenção de antropólogos e historiadores diz respeito às estimativas do contingente populacional indígena presente nas Américas por ocasião da chegada dos europeus no século XV-XVI. Conforme sumarizam Kennedy G Perz (2000), valendo-se de uma compilação dessas estimativas sobre os povos indígenas no Brasil em 1500, as cifras variam largamente, entre 800 mil e 5 milhões, a depender do autor e dos critérios utilizados. Dentre as várias tentativas de estimar a população indígena no passado (no Brasil e na América do Sul), é ilustrativo mencionar aquelas de Julian Steward e de William Denevan, pois apontam para algumas das dificuldades envolvidas.

Steward (1949) buscou estimar o tamanho da população indígena da América do Sul em 1500, baseando seus pressupostos em extrapolações a partir de valores de densidades populacionais segundo grandes áreas do continente, para tal utilizando uma tipologia fortemente influenciada pelo evolucionismo cultural corrente à época. Por exemplo, a região central do Brasil, ocupada por sociedades Jê, é referida como a de 'tribos marginais', já que se considerava que, em comparação com outros povos, eram tecnologicamente pouco desenvolvidos. Ressaltando as dificuldades metodológicas envolvidas, Steward chegou a um valor de aproximadamente 9,1 milhões de indígenas na América do Sul em 1500, que teria decrescido para 6,9 milhões em 1940. Doenças, guerras, perseguições e rupturas econômicas e sociais são apontadas como as principais causas responsáveis pela redução populacional. Para a área relativa ao Brasil, o autor estimou que era habitada por 1,1 milhão de indígenas em 1500, tendo decrescido para 500 mil em 1940. Um aspecto que chama a atenção nas estimativas de Steward é que, para 1940 , ele sugere que os indígenas equivaleriam a $11 \%$ da população total do Brasil (Steward, 1949:666).

Denevan (1976) procurou estimar o contingente populacional indígena do que chama de Grande Amazônia, que em sua definição engloba a área a leste e sul dos Andes, ao norte do Trópico de Capricórnio, excetuando a região do Chaco (portanto, surpreendentemente, inclui o Nordeste brasileiro). Esse autor também se apóia em extrapolações a partir de densidades populacionais. Contudo, de uma 
forma ainda mais proeminente que Steward, baseia-se em parâmetros ecológicoculturais, como a densidade populacional máxima possível a depender da capacidade de suporte conferida pelas formas de subsistência praticadas nos diferentes hábitats amazônicos. Denevan considera que as estimativas de Steward foram conservadoras e que, somente para a 'Grande Amazônia', a população indígena em 1500 atingiria 6,8 milhões de pessoas. ${ }^{6}$

Durante as décadas de 1940 a 1970 foram realizados alguns estudos para avaliar os efeitos da depopulação sobre a organização social das sociedades indígenas, provocados pelos contatos com as diferentes frentes de expansão. Charles Wagley (1942) inaugurou este campo no Brasil, com a análise das mudanças sociais advindas do contato dos Tapirapé, povo Tupi do Brasil Central, com as frentes expansionistas. Seguiu-se um outro estudo do mesmo autor, sobre as influências dos padrões culturais de duas populações de língua Tupi (os Tapirapé e os Tenetehara), mostrando a influência das instituições sociais e valores culturais sobre o tamanho destas populações após os contatos com as frentes de expansão (Wagley, 1951). Wagley apontou para a relativa estabilidade populacional alcançada pelos Tenetehara, que não conheciam certas práticas de restrição voluntária da natalidade e puderam, com elevadas taxas de natalidade, superar os altos níveis de mortalidade a que estavam sujeitos e continuar crescendo. Por outro lado, os Tapirapé, conhecedores de práticas reguladoras dos nascimentos, especialmente o aborto, teriam anulado seu potencial de crescimento ao experimentarem altas taxas de mortalidade em momentos de contato com a sociedade nacional.

Esses estudos deixaram fortes marcas na produção de Darcy Ribeiro que, aproximadamente no mesmo período, se dedicou à avaliação do impacto provocado pelas epidemias de doenças infecciosas sobre a demografia e a organização social dos povos indígenas, o que chamou de "efeitos dissociativos da depopulação". Ribeiro (1956) abordou um conjunto de estudos de casos sobre a ocorrência de epidemias de doenças infecciosas e parasitárias e as crises que se seguiram (freqüentemente agravadas pela fome em razão do colapso dos sistemas de subsistência), procurando documentar as reações das comunidades em vista das suas concepções socioculturais e as conseqüências sobre os padrões de organização social (ver também Ribeiro, 1957). Por intermédio dos vários casos analisados, o antropólogo também enfatizou que características internas próprias às diversas sociedades tinham o potencial de influenciar a trajetória demográfica no período subseqüente à crise populacional. Em linhas gerais, seu argumento é que há uma íntima associação entre características socioculturais e comportamento demográfico. ${ }^{7}$

Mais tarde, retomando alguns dos argumentos desenvolvidos em seu clássico estudo Convívio e Contaminação, de 1956, Darcy Ribeiro buscou correlacionar a depopulação experimentada pelos povos indígenas às diferentes situações de contato com a sociedade nacional (Ribeiro, 1977). Para tanto, elaborou 
uma classificação que se baseava em categorias de 'graus de integração' das sociedades indígenas (isoladas, em contato intermitente, em contato permanente e integradas) e nos tipos de frentes econômicas da sociedade nacional (extrativista, agrícola e pastoril). Os seus resultados apontaram para maiores perdas populacionais entre os povos que tiveram contato com frentes agrícolas, seguidos dos que se defrontaram com as expansões extrativistas e pastoris. Ribeiro conclui seu estudo com prognósticos bastante negativos quanto ao futuro dos povos indígenas, prevendo uma redução progressiva de sua população à medida que "passem de condição de isolamento à de integração" (Ribeiro, 1977:445), com a possibilidade de alguma recuperação populacional, asseguradas condições adequadas e uma vez integrados.

Laraia (1963), em artigo sobre os Suruí do Pará, demonstra como essa sociedade teve que produzir novos arranjos matrimoniais por causa das perdas populacionais que geraram um desequilíbrio entre os sexos. Assim sendo, os Suruí, que tradicionalmente praticavam a poliginia, passaram a praticar casamentos poliândricos, algo incomum entre as sociedades indígenas no Brasil.

Roberto Cardoso de Oliveira (1958) descreveu a estrutura demográfica dos Terêna da aldeia Cachoeirinha, que se localiza no que é o atual estado de Mato Grosso do Sul. Baseou-se em recenseamentos realizados pelo SPI entre 1919 e 1954 e em dados que coletou em 1957. O autor relacionou padrões de estrutura demográfica, de casamentos (intra e interétnicos) e reprodutivos às mudanças processadas na aldeia ante o contexto regional.

Uma linha de estudos relacionando aspectos genéticos e demográficos dos povos indígenas foi desenvolvida entre as décadas de sessenta e noventa pelos grupos de pesquisa coordenados pelos geneticistas Francisco Mauro Salzano e James Neel. Pela coleta de dados sobre a composição por idade e sexo, padrões de casamento, migração e outros aspectos demográficos, o interesse principal dessa linha de investigação é o de compreender a dinâmica micro-evolucionária e de produção da variabilidade biológica dos povos indígenas. Revisões detalhadas acerca dessas pesquisas podem ser encontradas em Salzano G Callegari-Jacques (1988) e Salzano G Bortolini (2002).

Estudos demográficos baseados em modelos de simulação computacional, visando reproduzir sistemas de parentesco em sociedades indígenas, desenvolveram-se a partir do início da década de setenta. MacCluer, Neel G Chagnon (1971) testaram um desses modelos na estimativa da estrutura da população Yanomami do Brasil e da Venezuela, com base em informações sobre as relações de parentesco. Numa perspectiva metodológica similar, Pozzobon (1994) investigou o tamanho mínimo de população necessário para fazer funcionar um sistema de parentesco de metades exogâmicas. Segundo o autor, o funcionamento desse sistema requer que o número de indivíduos pertencentes a cada metade não seja muito 
diferente. Em situação de desequilíbrio, os membros dessas populações teóricas recorrem a casamentos poligâmicos ou procuram cônjuges nas populações vizinhas ou ainda desobedecem às regras de casamento. $\mathrm{O}$ autor concluiu que o mínimo esperado para o funcionamento do sistema é de 500 indivíduos, distribuídos numa estrutura por idades e sexo estável.

No início da década de setenta, Frikel G Cortez (1972) analisaram o comportamento demográfico de três grupos Karib, localizados na missão franciscana do Alto Paru do Oeste (Pará e Amapá), os Ewarhoyána, Kaxúyana e Tiriyó. Os três grupos haviam sido submetidos a um drástico processo de depopulação antes de migrarem para a missão e, em 1970, se encontravam no curso de um significativo processo de recuperação populacional, possuindo, respectivamente, populações de 13, 64 e 222 indivíduos. Este estudo mostrou como é possível fazer avaliações demográficas de momento, extremamente detalhadas e precisas, apesar do reduzido número de indivíduos de determinados grupos indígenas.

Werner (1983a) conduziu uma análise antropológica e demográfica na qual procurou interpretar variações na fecundidade de mulheres Mekranoti-Kayapó, povo localizado no Pará, ao longo da então história recente do grupo, aproximadamente entre as décadas 1930 e 1970. Seus resultados indicaram que houve uma redução da taxa de fecundidade total (TFT) no período de contato (19551964), que foi de 5,6 filhos por mulher, em comparação à fase anterior (TFT=6,5) e posterior ( $\mathrm{TFT}=8,5$ ). Interessado em identificar os determinantes próximos da variação na fecundidade, Werner sugeriu que uma das principais razões foi o desequilíbrio na composição por sexo entre adultos no período de contato. Isso porque muitos homens morreram por conta de conflitos e doenças, deixando um grande contingente de mulheres adultas sem parceiros.

Em outro estudo, teórica e metodologicamente menos abrangente, Werner (1983b) comparou alguns indicadores de fecundidade e de mortalidade dos Xokleng do Posto Indígena Ibirama, localizado em Santa Catarina, com aqueles de não indígenas de uma comunidade próxima. Como esperado, os níveis de mortalidade dos indígenas mostraram-se bem mais elevados. Um achado que chama atenção é a elevadíssima taxa de fecundidade total reportada para as mulheres xokleng no período 1975-1983, de 11,0 filhos por mulher, mais que o dobro daquela das mulheres não-indígenas investigadas (5,3 filhos).

Na década de 1970, Junqueira e Camargo realizaram investigação sobre o comportamento reprodutivo das mulheres Kamaiurá, índios Tupi do Alto Xingu (MT). Os autores discutiram os preceitos teóricos que envolvem os fatores constitutivos das variáveis intermediárias da fecundidade, propostos por Davis e Blake. Esse trabalho, que na época não foi publicado, é parte da contribuição de Junqueira et al. para este volume. 
No início da década de oitenta, a Abep já manifestava o interesse em inserir em sua pauta de discussões temas relativos à demografia dos povos indígenas. Neste sentido, o programa de seu III Encontro Nacional, realizado em Vitória (ES), contou com uma sessão temática dedicada à 'Demografia dos Grupos Étnicos Minoritários', na qual foram discutidos quatro trabalhos. Fígoli (1982) apresentou um estudo sobre identidade e etnicidade em áreas urbanas, enfocando a imigração de indígenas da região do Rio Negro para Manaus, com uma avaliação acerca do volume dessa população segundo áreas de emigração, condições de deslocamento e rotas migratórias. Romano (1982) abordou aspectos relicionados às condições de vida e inserção no mercado de trabalho de indígenas Sateré-Mawé moradores da cidade de Manaus. Salzano (1982) apresentou algumas tendências demográficas observadas em um conjunto de povos indígenas, sobretudo no que tange a níveis de mortalidade, de fecundidade e padrões de uniões, dados esses coletados ao longo de duas décadas de investigações no campo da genética de populações. Finalmente, Lux Vidal, coordenadora da sessão, apresentou um balanço das dificuldades encontradas para estimar a evolução demográfica dos povos indígenas no Brasil, numa perspectiva histórica ou mesmo atual, decorrente da precariedade e irregularidade das informações quantitativas disponíveis. Já naquele momento a antropóloga propunha a implementação de um projeto de estudos sobre demografia indígena e a reformulação da coleta e tratamento dos dados dos recenseamentos oficiais.

O IV Encontro Nacional da Abep, realizado em Águas de São Pedro (SP) em 1984, também contemplou o tema, pela inclusão em sua programação de uma sessão sobre Etnia e População, coordenada por Laura Wong. A discussão levantou questões sobre o tamanho das populações e das terras indígenas, as migrações para áreas urbanas, a realização de um censo indígena e a criação de um sistema de estatísticas contínuas para garantir as informações necessárias à realização de estudos demográficos (Wong, 1984). Os trabalhos apresentados versaram ainda sobre padrões de uniões matrimoniais e endogamia de 18 grupos indígenas (Salzano, 1984); informaçöes sobre o número de filhos tidos, nascidos vivos e mortos, de mulheres Cinta Larga de Rondônia e Mato Grosso, no período 1979 e 1984 (Junqueira, 1984); e reflexões gerais sobre a demografia indígena, quando foram colocadas em discussão as contribuições que esses estudos podem trazer à demografia e vice-versa (Penna, 1984).

Nos anos seguintes, a discussão aberta pela Abep estimulou a realização de diversos estudos de modelo transversal. Wong (1986) analisou a dinâmica demográfica dos Kaigang, Terena e Guarani, moradores de áreas indígenas do estado de São Paulo, estimando níveis de mortalidade, fecundidade e migração, com informações dos anos de 1976 e 1985. Meireles (1988) comparou os padrões reprodutivos de três sociedades indígenas, os Karitiana, Tupi da família Arikên, os 
Gaviões, Tupi da família Mondé, e os Pakaas-Novos, da família Txapakura. Fundamentada na aplicação de um modelo que pressupõe que diferenças na organização social das populações resultam em variações de seus padrões de fecundidade, a autora conclui que a ocorrência de mudanças sociais afetou a fecundidade desses grupos no sentido de um notável aumento.

Vale destacar a publicação de um fascículo temático do periódico South American Indian Studies sobre demografia em 1994 (Adams G Price, 1994). Os trabalhos que o compõem dedicam-se à analise demográfica e etnológica de 'sociedades de pequena escala', com foco no diálogo entre o comportamento demográfico e cultural. A tônica de algumas contribuições é o debate de idéias neomaltusianas (ver, por exemplo, Adams G Price, 1994 e Picchi, 1994), considerando a recuperação demográfica no período pós-contato, suas implicações para a sobrevivência diante da escassez de recursos alimentares e ambientais e os problemas de saúde associados. Para fins de ilustração, podem ser mencionados alguns estudos específicos: Greene G Crocker (1994), sobre o comportamento demográfico dos Canela moradores da região do Escalvado (MA), baseado em dados coletados em diversos momentos do período 1970 a 1988, associados às informações sobre o sistema de parentesco, relações entre grupos familiares, padrões de residência, estado matrimonial e algumas histórias reprodutivas, com uma discussão sobre a relação entre os níveis de fecundidade e a existência de uniões poligâmicas; Price (1994), sobre o comportamento demográfico de alguns grupos Nambiquara (MT), com informações sobre nascimentos e óbitos entre 1943 e 1969, extraídos do registro civil do posto indígena do SPI, dados do próprio autor, de missionários religiosos e agentes indígenas de saúde, coletados em diferentes momentos do período 1969-1986; Picchi (1994), sobre os Bakairi (MT), com informações sobre domicílios, composição por idade e sexo, casamento, mortalidade e fecundidade e algumas variáveis intermediárias, para o período 1979-1989; Flowers (1994) sobre o comportamento demográfico dos Xavánte de Pimentel Barbosa (MT), com dados do período 1976-1990, relativos a eventos vitais, histórias reprodutivas, saúde infantil, consumo alimentar, produtividade agrícola e de caça. A autora avaliou o tamanho, crescimento, taxas de fecundidade e alguns de seus determinantes próximos pela construção de coortes de mulheres, taxas de mortalidade e probabilidades de sobrevivência.

A pesquisa de Early G Peters (1990) consiste de um detalhado estudo transversal e longitudinal a respeito da dinâmica demográfica dos Yanomama moradores do rio Mucajai, na região Norte do Brasil, próximo à fronteira da Venezuela, com dados de observação de um período de 27 anos. Posteriormente, esses autores expandiram suas pesquisas demográficas para outros grupos Yanomama (Early G Peters, 2000). Tais investigações estão dentre as mais 
detalhadas análises demográficas já realizadas sobre os povos indígenas no Brasil, como atesta a entrevista com John Early (neste volume).

Sobre os Waiãpi, um grupo Tupi-Guarani residente no Amapá, os resultados de Azevedo (1996) mostram uma população com altos níveis de fecundidade e baixa mortalidade, que cresceu a um ritmo de 4,1\% entre 1980 e 1996 e com expectativa de duplicação em 17 anos. Em outro estudo sobre este mesmo grupo indígena, Medeiros (2000) estima a média de idade da mãe ao nascimento do primeiro filho e os intervalos intergenésicos de nascimentos observados em 1985 e 1998.

O estudo de Souza G Santos (2001) sobre os Xavánte de Sangradouro Volta Grande analisa o comportamento demográfico de sete aldeias, com base em censos anuais e registros de eventos vitais do período 1993-1997. Estimam-se taxas de natalidade, de fecundidade e de mortalidade geral e infantil que são associadas às mudanças sociais e padrões culturais. Uma ênfase do trabalho é a interpretação das informações demográficas e de mortalidade em particular à luz de discussões no campo da saúde pública. Entre outros aspectos, os autores mostram que não somente os óbitos estão desproporcionalmente concentrados em crianças, como o nível de mortalidade infantil é muito superior à média nacional, o que aponta para as precárias condições de saneamento e inadequado serviço de atenção à saúde dos Xavánte.

O livro de Carlos Coimbra Jr., Nancy Flowers, Francisco M. Salzano e Ricardo Ventura Santos, intitulado The Xavánte in Transition, é um estudo sobre a comunidade de Pimentel Barbosa (ou Etéñitépa), abordando aspectos ligados à saúde, ecologia humana e antropologia biológica em estreito diálogo com dados etnológicos e históricos, com o intuito de compreender processos de mudanças sociais, econômicas, políticas e epidemiológicas numa perspectiva diacrônica (Coimbra Jr. et al., 2002). Um componente explorado pelos autores diz respeito à dinâmica demográfica no período compreendido aproximadamente entre 1940 e 1990, com ênfase nas inter-relações entre o contato com a sociedade nacional e seus impactos sobre a dinâmica demográfica, incluindo padrões de mortalidade, fecundidade e nupcialidade (ver Santos et al., neste volume).

Gomes (2002) apresenta uma reconstrução histórica da demografia Tenetehara nos últimos quatrocentos anos. Segundo esse autor, a tendência de crescimento dos Tenetehara começou a se esboçar no início da década de 1950, atingindo níveis próximos a 5\% ao ano entre 1975 e 1994, após um longo período de descenso populacional. A sensível queda da mortalidade infantil e as modificações nas regras de tabus sexuais pós-parto, que reduziram o espaçamento entre os nascimentos, são apontadas como fatores prováveis do crescimento registrado nesse período. A diminuição e estabilização do ritmo de crescimento a partir de 1994, quando são registrados índices em torno de $3 \%$ ao ano, refletiriam 
as dificuldades em aumentar a produção de alimentos, o recrudescimento de doenças infecciosas e crônicas, a deterioração da assistência à saúde e a provável retomada de tabus sexuais após o nascimento dos filhos. Para melhor avaliar o crescimento observado, Gomes estima níveis de mortalidade infantil e na infância e níveis de fecundidade, por meio de um inquérito realizado com amostra extraída entre as mulheres casadas com idades entre 16 e 73 anos. Esta observação permitiu ao autor inferir sobre o aumento da média de filhos tidos nascidos vivos e a diminuição dos intervalos intergenésicos.

A partir de 1992, o programa de saúde do Parque Indígena do Xingu, Unifesp/EPM, através de sua Unidade de Saúde e Meio Ambiente (Usma), deu início a uma linha de pesquisas sobre demografia. Ao longo da última década, utilizando os dados do registro contínuo da população, avaliou-se a dinâmica demográfica de seis povos com ênfase nas relações entre padrões demográficos e culturais. O primeiro estudo estimou o tamanho, crescimento, estrutura por idade e sexo, padrões de mortalidade e esperança de vida dos Panará (Kren-akrore) para o período 1973-1993, quando estes ainda moravam no Parque Indígena do Xingu (Baruzzi et al., 1994). O segundo, sobre os Waurá, reuniu dados de 1970 a 1999 , para analisar a dinâmica populacional e o comportamento da fecundidade deste grupo, que teve seu crescimento aumentado de 3 para $5 \%$ ao ano (Pagliaro et al., 2001). A seguir foram estudados três dos quatro grupos Tupi moradores do Parque, os Kaiabi (Pagliaro, 2002 e neste volume), Juruna (Pagliaro et al., 2003), Kamaiurá (Pagliaro et al., 2004), restando apenas os Aweti, em fase de elaboração. Atualmente, está sendo desenvolvida uma investigação sobre os Txikão (Maia et al., 2004).

Por esse breve levantamento da literatura sobre demografia dos povos indígenas no Brasil fica evidente que o interesse pelo tema iniciou-se há várias décadas, com a participação de pesquisadores trabalhando com várias vertentes teóricas e metodológicas. Daí resulta ser difícil gerar uma síntese sobre a demografia dos povos indígenas, já que os estudos são bastante diversificados.

Não obstante, há um eixo temático que, de certo modo já presente nos primórdios das pesquisas voltadas para questões demográficas, como aquelas desenvolvidas por Charles Wagley, Darcy Ribeiro e outros autores nas décadas 1940 e 1950, vem-se consolidando como vertente analítica proeminente na demografia dos povos indígenas no período mais recente. Estamos nos referindo aos estudos que, privilegiando análises pautadas em um conhecimento detalhado da história e etnologia dos povos investigados, tratam das repercussões sobre o comportamento demográfico resultante das múltiplas formas de interação com a sociedade nacional envolvente, sejam eles sobre as dinâmicas de mortalidade, fecundidade, migração ou nupcialidade, sejam eles sobre outros aspectos. Ressaltese que surge na safra mais recente de estudos uma clara sinalização de que as análises do comportamento demográfico dos povos indígenas precisam 
necessariamente levar em conta a organização social que, como bem demonstrado, é amplamente diversificada. Este tipo de estudo, conhecido por demografia antropológica, antropodemografia, etnodemografia, entre outras denominações que recebe, vem buscando estabelecer a complexa relação entre modelos culturais e padrões demográficos.

No plano da metodologia, a revisão da literatura também delineia um quadro relativamente claro. As deficiências das estatísticas sobre os povos indígenas no Brasil não oferecem mais do que avaliações conjunturais do estado destas populações em determinados momentos do tempo. Por outro lado, as pesquisas baseadas em registros contínuos de informações, de modelo longitudinal e que demandam dados coletados durante longos períodos de tempo, são ainda raras. Estes tipos de estudo permitem observar as variações dos padrões de fecundidade e de mortalidade ao longo do tempo, de difícil detecção em inferências transversais ou de momento.

\section{Desdobramentos recentes}

Em março de 2002, por iniciativa da Abep, foi criado o Comitê de Demografia dos Povos Indígenas, reunindo demógrafos e antropólogos interessados em estudar a articulação entre os processos demográficos e a organização social das sociedades indígenas no Brasil, de forma a preencher a lacuna existente neste campo de estudos. A sua estruturação foi gestada em agosto de 2001, por ocasião da XXIV Conferência Geral de População da International Union of Scientific Studies of Population (Iussp), realizada em Salvador, com base na demanda de um grupo de associados da Abep interessados neste campo de estudos e dispostos a enfrentar o desafio que representa estimar indicadores demográficos para as "populações de pequena escala" e interpretá-los à luz de informações sobre a cultura desses povos.

O Comitê buscou definir alguns eixos de trabalho, sobre os quais deveriam versar as discussões iniciais, que resultaram em duas sessões temáticas e uma mesa-redonda realizadas no XIII Encontro da Abep, que teve lugar em Ouro Preto, em 2002, a saber: 1) Comportamento demográfico e organização social dos povos indígenas no Brasil; 2) Indicadores de saúde e sociodemográficos para essas populações. Em 2003, o Comitê organizou um seminário, que contou com o apoio da Abep, da Unifesp e do Fnuap, reunindo pesquisadores com produção na área, com a participação de John Early, professor da Florida Atlantic University e autor em conjunto com John Peters dos relevantes estudos sobre os Yanomami (ver Early neste volume). Vale também mencionar a interação do Comitê com o Grupo de Trabalho sobre Saúde dos Povos Indígenas da Associação Brasileira de Pós-Graduação em Saúde Coletiva (Abrasco), pois, por causa dela, foi realizada durante o 
VII Congresso Brasileiro de Saúde Coletiva, que aconteceu em Brasília, em agosto de 2003, uma mesa sobre 'Demografia e Saúde dos Povos Indígenas'.

Os capítulos que constituem esta coletânea foram apresentados em sessões organizadas pelo Comitê de Demografia dos Povos Indígenas no período 2002-2004. Abordam aspectos variados do comportamento demográfico dos povos indígenas no Brasil, sobretudo acerca de padrões de mortalidade, fecundidade, nupcialidade e migração. Uma outra característica importante é o estreito diálogo que os autores desenvolvem com teorias e métodos de disciplinas próximas da demografia, incluindo antropologia, história e saúde coletiva, para destacar algumas das áreas mais proeminentes.

Marta Maria Azevedo trata das análises dos tipos de casamentos existentes entre os povos habitantes da região do alto rio Negro, noroeste do estado do Amazonas, tendo como fonte de dados o censo indígena autônomo do rio Negro implementado em 1992 pela Federação das Organizações Indígenas do Rio Negro. Para isso a região enfocada foi subdividida em cinco sub-regiões, tendo como critérios a ocupação da área pelos diferentes povos indígenas e sua delimitação geográfica. Na primeira parte do trabalho, são resumidas as formulações teóricas, elaboradas por diferentes antropólogos, sobre os tipos de casamento rio-negrino. A seguir, são analisados os dados oriundos do referido censo, a partir dos quais a autora demonstra que confirmam em grande parte as teorias previamente discutidas.

Ricardo Ventura Santos, Nancy Flowers e Carlos E. A. Coimbra Jr. apresentam um estudo de caso sobre os Xavánte de Pimentel Barbosa, ou Etéñitépa, no qual buscam caracterizar a crise demográfica nas décadas que se seguiram ao contato da década de 1940. A crise resultou de níveis mais elevados de mortalidade, devido tanto a epidemias como à violência, e de uma queda da fecundidade. A partir da década 70, decresceu a mortalidade, e a população iniciou um período de rápido crescimento. A crise demográfica foi influenciada não somente por fatores externos, mas também por aspectos ligados à organização social do grupo. Adicionalmente, o caso dos Xavánte de Etéñitépa indica que o impacto das epidemias envolve mais que a redução da população, influenciando dinâmicas sociais, como as práticas matrimoniais, mesmo décadas após a crise.

Heloisa Pagliaro analisa a dinâmica demográfica dos Kaiabi do Parque Indígena do Xingu (PIX) durante um período de 1970 a 1999, mostrando como a imigração deste povo, da região do Alto Teles Pires para o PIX, contribuiu para a sua sobrevivência e recuperação populacional. Para o elevado crescimento populacional observado no período, alguns fatores podem ter sido decisivos, tais como: a cessação de conflitos com as frentes expansionistas, a menor exposição às epidemias, a melhoria das condições de saúde, a garantia do território, além do desejo e da decisão de crescer. $\mathrm{O}$ trabalho evidencia como um sistema de registro 
contínuo de eventos vitais e de mobilidade espacial pode permitir a construção de indicadores demográficos por meio de modelos de análise transversal e longitudinal.

Paulo Campanário descreve um modelo demográfico para estimar a mortalidade e a fecundidade de populações de 'pequena escala', usando como exemplo para a aplicação de seu modelo a população Kaiabi. Os resultados do exercício apontam a estreita concordância com as análises realizadas por Pagliaro (neste volume), que se basearam em métodos diretos. O trabalho mostra ainda como a aplicação do modelo a outras populações indígenas, sem registro de eventos demográficos, valendo-se de simples contagens populacionais para um determinado ano ou período de tempo, pode resultar em construções de séries temporais e projeções que permitem análises diacrônicas. Portanto, trata-se de uma ferramenta particularmente útil no caso dos povos indígenas no Brasil, visto a já citada carência de informações demográficas.

Cândido Procópio Ferreira de Camargo, Carmen Junqueira e Heloísa Pagliaro apresentam reflexões sobre o comportamento reprodutivo das mulheres Kamaiurá do Alto Xingu. O capítulo encontra-se estruturado em duas partes. Na primeira, está reproduzido um texto original de Junqueira e Camargo, escrito na década de 1970, em que os autores analisam o comportamento reprodutivo das mulheres kamaiurá (Alto Xingu) e discutem os preceitos teóricos que envolvem os fatores constitutivos das variáveis intermediárias da fecundidade; na segunda, são apresentadas reflexões acerca de aspectos culturais e demográficos, registrados em visita recente aos Kamaiurá, que apontam para um aumento da média de filhos por mulher e, em particular, um substancial incremento na média de filhos sobreviventes nos primeiros anos de vida em virtude da melhoria das condições de saúde.

Pery Teixeira e Marília Brasil apresentam os resultados, procedendo a uma análise sobre o Diagnóstico Sociodemográfico Participativo da População SateréMawé, um povo localizado no estado do Amazonas. Essa pesquisa surgiu a partir da convergência de interesses de um grupo de instituições e organizações indígenas e não-indígenas, governamentais e não-governamentais, objetivando conhecer as condições de vida e de sustentabilidade dos povos indígenas da Amazônia Brasileira. Os dados apresentados referem-se ao volume dos efetivos populacionais SateréMawé, sua distribuição espacial e a composição por sexo e idade. Além disso, a natalidade e a fecundidade são tratadas do ponto de vista comparativo entre as diferentes áreas habitadas pelos Sateré-Mawé, inclusive entre as terras indígenas e as áreas urbanas.

Nilza de Oliveira Martins Pereira, Ricardo Ventura Santos e Marta Maria Azevedo apresentam um perfil demográfico e socioeconômico das pessoas que se autodeclararam 'indígenas' nos Censos de 1991 e 2000. Um aspecto relevantíssimo que emerge da comparação dos dois censos é o crescimento expressivo no número de indivíduos que se autodeclararam como 'indígenas' 
(294 mil em 1991 e 734 mil em 2000). São discutidos, também, aspectos relacionados à composição etária e por sexo, distribuição geográfica e por região (urbana e rural), componentes da dinâmica demográfica e algumas características sociais e econômicas. Além de frisar quanto aos desafios interpretativos no tocante aos indivíduos que se autodeclararam 'indígenas', os autores enfatizam que a formulação do quesito sobre cor/raça em censos futuros precisa ser aperfeiçoada.

A última contribuição desta coletânea é uma entrevista com o professor John Early, antropólogo e demógrafo, com vários trabalhos publicados sobre os Yanomami, bem como com contribuições para a demografia antropológica de povos nativos de outras regiões do mundo. Early discorre na entrevista sobre as várias etapas de seu trabalho com os Yanomami, realizado juntamente com o antropólogo John Peters, incluindo as dificuldades metodológicas enfrentadas, as diversas fontes de informações consultadas, as estratégias para os cálculos de idade, entre outros aspectos. Early chama atenção para o fato de que este trabalho com os Yanomami, que cobre sete décadas de informações populacionais, mostra que a combinação de dados históricos, etnográficos e demográficos resulta em uma análise mais fina e profunda.

1 A Fundação Nacional do Índio (Funai) estima que em 2004 "vivem no Brasil cerca de 345 mil índios, distribuídos entre 215 sociedades indígenas, que perfazem cerca de $0,2 \%$ da população brasileira. Cabe esclarecer que este dado populacional considera tão-somente aqueles indígenas que vivem em aldeias, havendo estimativas de que, além destes, há entre 100 e 190 mil vivendo fora das terras indígenas, inclusive em áreas urbanas. Há também indícios da existência de mais ou menos 53 grupos ainda não contatados, além de existirem grupos que estão requerendo o reconhecimento de sua condição indígena junto ao órgão federal indigenista" (http://www.funai.gov.br, acessado em 13/08/2004). O Instituto Brasileiro de Geografia e Estatística (IBGE), por sua vez, estima que em 2000 viviam no Brasil 715 mil pessoas, que se autodeclaram indígenas para o censo demográfico (ver Pereira et al., neste volume).

2 O rápido crescimento populacional dos povos indígenas não é um fenômeno que se limita ao Brasil, mas vem acontecendo também em vários outros países da América Latina, como demonstra o recente estudo comparativo de McSweeney 6 . Arps (2005).

3 Sobre os povos indígenas nos censos brasileiros, consultar Azevedo (2000) e Oliveira (1997).

4 Em 1940 o censo demográfico, ao pesquisar línguas faladas, acabou chegando a um grande número de pessoas falantes de língua 'Tupi' e outras línguas indígenas. Esses dados, potencialmente informativos acerca das populações indígenas, permanecem inexplorados (Azevedo, 1997).

5 Há ainda poucas análises sobre os dados sobre indígenas dos Censo de 1991 e 2000 (ver, por exemplo, Pereira, 2002; Pereira G Azevedo, 2004; Pereira et al., neste volume; Kennedy G 
Perz, 2000). Enfocando os indígenas, Azevedo (2000), Kennedy G Perz (2000), Santos G Coimbra Jr. (2003) e Silva (1994) apresentam comentários críticos quanto aos procedimentos empregados nos levantamentos censitários e como podem ter influenciado as estimativas de tamanho e de distribuição geográfica, entre outros aspectos demográficos.

6 A partir da década de 1990, a questão do tamanho populacional e da complexidade da organização social dos povos indígenas na Amazônia no passado voltou a ser tema de grande interesse na antropologia, com contribuições significativas de etnólogos e arqueólogos. Vários estudos apontam que, de fato, os contingentes populacionais indígenas deveriam ser expressivos, chamando-se a atenção para as limitações de projeções que tomem os povos indígenas no presente como referência (ver Fausto, 2001; Roosevelt, 1994; Viveiros de Castro, 1996). Um exemplo ilustrativo é o estudo de caso de Heckenberger $(2001,2005)$ que, apoiando-se em evidências arqueológicas e etno-históricas, discute a construção do pluralismo xinguano ao longo dos séculos e também aborda o colapso populacional no Alto Xingu a partir do século XIX.

7 Para uma discussão sobre as inter-relações entre epidemias de doenças infecciosas, depopulação e organização social em povos indígenas no Brasil, ver Coimbra Jr. (1987), cujo trabalho recupera alguns dos argumentos de Ribeiro (1956). Um debate abordado por Coimbra Jr. refere-se à contribuição diferencial de fatores biológicos (i.e., hipótese de uma maior suscetibilidade biológica dos povos indígenas às epidemias devido a características genéticas próprias) vis-à-vis sociocomportamentais (i.e., colapso social, associado à desestruturação das atividades de subsistência, levando a situações de penúria, fome e debilidade orgânica) na explicação quanto aos altos níveis de mortalidade observados em povos indígenas frente às epidemias. Esse debate acerca dos determinantes da depopulação perante as epidemias permanece corrente (Black, 1994, 2004; Hurtado et al., 2004).

Referências Bibliográficas

ADAMS, K. G PRICE, D. Introduction. The demography of small scale societies: case studies from Lowland South America. South American Indian Studies, 4:1-4, 1994.

AZEVEDO, M. Demografia dos povos indígenas do Alto Rio Negro. Revista Brasileira de Estudos de População, 11:235-244, 1994.

AZEVEDO, M. Análise Demográfica da População Waiâpi - anos 1980.a 1985. Campinas: Núcleo de Estudos de População/Universidade Estadual de Campinas, 1996. (Mimeo.)

AZEVEDO, M. Censos demográficos e "os índios": dificuldades para reconhecer e contar. In: RICARDO, C. A. (Org.) Povos Indígenas no Brasil 1996/2000. São Paulo: Instituto Socioambiental, 2000. p.79-83.

BARUZZI, R. G.; MARCOPITO, L. F. G IUNES, M. Programa médico-preventivo da Escola Paulista de Medicina no Parque Nacional do Xingu. Revista de Antropologia, 21:155$170,1978$.

BARUZZI, R. G. et al. Os índios Panará: a busca pela sobrevivência. Anais do Encontro Nacional de Estudos Populacionais, 2:225-243, Caxambu: Associação Brasileira de Estudos Populacionais - Abep, 1994. 
BLACK, F. L. Infecção, mortalidade e populações indígenas: homogeneidade biológica como possível razão para tantas mortes. In: SANTOS, R. V. G COIMBRA Jr., C. E. A. (Orgs.) Saúde G Povos Indígenas. Rio de Janeiro: Ed. Fiocruz, 1994. p.63-87.

BLACK, F. L. Disease susceptibility among New World peoples. In: SALZANO, F. M. G HURTADO, A. M. (Orgs.) Lost Paradises and the Ethics of Research and Publication. Oxford: Oxford University Press, 2004. p.146-163.

COIMBRA Jr., C. E. A. O sarampo entre sociedades indígenas brasileiras e algumas considerações sobre a prática da saúde pública entre essas populações. Cadernos de Saúde Pública, 3:22-37, 1987.

COIMBRA Jr., C. E. A. et al. The Xavánte in Transition: health, ecology and bioanthropology in Central Brazil. Ann Arbor: University of Michigan Press, 2002.

DENEVAN, W. M. The aboriginal population of Amazonia. In: DENEVAN, W. M. (Org.) The Native Population of the Americas in 1492, Madison: University of Wisconsin Press, 1976. p.205-234.

EARLY, J. D. G PETERS, J. F. The Population Dynamics of the Macujaí Yanomama. New York: Academic Press, 1990.

EARLY, J. D. G PETERS, J. F. The Xilixana Yanomami of the Amazon. Gainesville: University Press of Florida, 2000.

FAUSTO, C. Os Índios Antes do Brasil. Rio de Janeiro: J. Zahar, 2001.

FIGOLI, L. H. G. Migração indígena a Manaus. Anais do III Encontro Nacional de Estudos Populacionais, p.397-398. Vitória: Associação Brasileira de Estudos Populacionais - Abep, 1982.

FLOWERS, N. M. Crise e recuperação demográfica: os Xavánte de Pimentel Barbosa, Mato Grosso. In: SANTOS, R. V. G COIMBRA Jr., C. E. A. (Orgs.) Saúde G Povos Indígenas. Rio de Janeiro: Ed. Fiocruz, 1994. p.213-242.

FRIKEL, P. G CORTEZ, R. Elementos Demográficos do Alto Paru de Oeste, Tumucumaque Brasileiro. Índios Ewarhoyána, Kaxúyana e Tiriyó. Publicações Avulsas do Museu Paraense Emílio Goeldi, n.19, 1972. 107p.

GARNELO, L.; MACEDO, G. G BRANDÃO, L. C. Os Povos Indígenas e a Construção da Política de Saúde no Brasil. Brasília: Organização Pan-Americana da Saúde, 2003.

GOMES, M. P. O Índio na História: o povo Tenetehara em busca da liberdade. Petrópolis: Vozes, 2002.

GREENE, M. E. G CROCKER, W. H. Some demografic aspects of the Canela indians of Brazil. South American Indian Studies, 4:47-62, 1994.

HECKENBERGER, M. Epidemias, índios bravos e brancos: contato cultural e etnogênese no Alto Xingu. In: FRANCHETTO, B. G HECKENBERGER, M. (Orgs.) Os Povos do Alto Xingu: história e cultura. Rio de Janeiro: Ed. da UFRJ, 2001. p.77-110.

HECKENBERGER, M. The Ecology of Power: culture, place and personhood in the Southern Amazon, Ad 1000-2000. London: Routledge, 2005.

HURTADO, A. M., HURTADO, I. G HILL, K. Public health and adaptive immunity among natives of South America. In: SALZANO, F. M. G HURTADO, A. M. (Orgs.) Lost 
Paradises and the Ethics of Research and Publication. Oxford: Oxford University Press, 2004. p.164-190.

JUNQUEIRA, C. Alguns dados sobre a população Cinta Larga. Anais do IV Encontro Nacional de Estudos Populacionais, 3:1585-1587, Águas de São Pedro: Associação Brasileira de Estudos Populacionais - Abep, 1984.

KENNEDY, D. P. G PERZ, S. G. Who are Brazil's Indígenas? Contributions of census data analysis to anthropological demography of indigenous populations. Human Organization, 59:311-324, 2000.

LARAIA, R. Arranjos poliândricos na sociedade suruí. Revista do Museu Paulista, Nova Série, XIV:71-75, 1963.

MACCLUER, J. W.; NEEL, J. V. G CHAGNON, N. Demographic structure of a primitive population: A simulation. American Journal of Physical Anthropology, 35:193207, 1971.

MAIA, S. F. et al. A recuperação populacional dos Txicão (Ikpeng), Parque Indígena do Xingu (1970-1999). Trabalho apresentado no XIV Encontro Nacional de Estudos Populacionais, disponível em http://www.abep.org.br, Caxambu: Associação Brasileira de Estudos Populacionais - Abep, 2004.

MCSWEENEY, K. G ARPS, S. A "demographic turnaround": the rapid growth of indigenous populations in lowland Latin America. Latin American Research Review, 40:3-29, 2005.

MEDEIROS, L. Population Dynamics of the Waiãpi of Brazil: demographic insights on the changing reproductive behavior of a indigenous culture. Trabalho de conclusão de bacharelado em Estudos Ambientais, Chicago: Universidade de Chicago, 2000.

MEIRELES, D. M. Sugestões para uma análise comparativa da fecundidade em populações indígenas. Revista Brasileira de Estudos Populacionais, 51:1-20, 1988.

OLIVEIRA, J. P. Pardos, mestiços ou caboclos: os índios nos censos nacionais no Brasil (1872-1980). Horizontes Antropológicos, 3:60-83, 1997.

OLIVEIRA, R. C. Aspectos demográficos e ecológicos de uma comunidade Terêna. Boletim do Museu Nacional, 18:1-17, 1958.

PAGLIARO, H. A Revolução Demográfica dos Povos Indígenas no Brasil: a experiência dos Kaiabi do Parque Indígena do Xingu, Mato Grosso (1970-1999), 2002. Tese de Doutorado, São Paulo: Faculdade de Saúde Pública, Universidade de São Paulo.

PAGLIARO, H. et al. Comportamento demográfico dos índios Waurá no final do século XX. Proceedings of the XXIV $V^{\text {h }}$ General Population Conference, p.1583-1594, Salvador: International Union of Scientific Studies of Population - Iussp, 2001.

PAGLIARO, H. et al. Comportamento demográfico dos índios Kamaiurá, Parque Indígena do Xingu (1970-1999). Trabalho apresentado no XIV Encontro Nacional de Estudos Populacionais, disponível em http://www.abep.org.br. Caxambu: Associação Brasileira de Estudos Populacionais - Abep, 2004.

PENNA, T. C. F. Por que demografia indígena brasileira. Anais do IV Encontro Nacional de Estudos Populacionais, 3:1571-1583, Águas de São Pedro: Associação Brasileira de Estudos Populacionais - Abep, 1984. 
PICCHI, D. Observations about a Central Brazilian indigenous population: The Bakairi. South American Indian Studies, 4:37-46, 1994.

POZZOBON, J. O mínimo demográfico de um sistema de metades exogâmicas (uma simulação em computador). Revista Brasileira de Estudos de População, 11:139$154,1994$.

PRICE, D. Notes on Nambiquara demography. South American Indian Studies, 4:63-76, 1994.

RIBEIRO, D. Convívio e contaminação. Efeitos dissociativos da depopulação provocada por epidemias em grupos indígenas. Sociologia, 18:3-50, 1956.

RIBEIRO, D. Culturas e línguas indígenas do Brasil. Educação e Ciências Sociais, II(6):4102, 1957.

RIBEIRO, D. Os Índios e a Civilização: a integração das populações indígenas no Brasil moderno. Rio de Janeiro: Vozes, 1977.

RICARDO, C. A. (Org.) Povos Indígenas no Brasil 1991/1995. São Paulo: Instituto Socioambiental, 1996.

RICARDO, C. A. (Org.) Povos Indígenas no Brasil 1996/2000. São Paulo: Instituto Socioambiental, 2000.

ROMANO, J. O. Etnicidad y proletarización. Anais do III Encontro Nacional de Estudos Populacionais, p.399-401, Vitória: Associação Brasileira de Estudos Populacionais - Abep, 1982.

RoOsevelt, A., (Org.) Amazonian Indians: From Prehistory to the Present. Tucson: University of Arizona Press, 1994.

SALZANO, F. M. Fertilidade, mortalidade, migração e miscigenação em 14 Tribos indígenas da América do Sul. Anais do III Encontro Nacional de Estudos Populacionais, p.15651570. Vitória: Associação Brasileira de Estudos Populacionais - Abep, 1982.

SALZANO, F. M. Migração, etnia e casamento de indígenas sul-americanos. Anais do IV Encontro Nacional de Estudos Populacionais, 3:1565-69, Águas de São Pedro: Associação Brasileira de Estudos Populacionais - Abep, 1984.

SAlZANO, F. M. G CALlEGARI-JACQUES, S. M. South American Indians: A Case Study in Human Evolution. Oxford: Clarendon Press, 1988.

SAlZANO, F. M. G BORTOLINI, M. C. The Evolution and Genetics of Latin American Populations. Cambridge: Cambridge University Press, 2002.

SANTOS, R. V. G COIMBRA Jr., C. E. A. Cenários e tendências da saúde e da epidemiologia dos povos indígenas no Brasil. In: COIMBRA Jr., C. E. A., SANTOS, R. V. G ESCOBAR, A. L. (Orgs.) Epidemiologia e Saúde dos Povos Indígenas no Brasil. Rio de Janeiro: Ed. Fiocruz/Associação Brasileira de Saúde Coletiva - Abrasco, 2003. p.13-47.

SILVA, M. F. A demografia e os povos indígenas no Brasil. Revista Brasileira de Estudos de População, 11:261-264, 1994.

SOUZA, L. G. G SANTOS, R. V. Perfil demográfico da população indígena Xavánte de Sangradouro - Volta Grande, Mato Grosso (1993-1997), Brasil. Cadernos de Saúde Pública, 17:355-366, 2001. 
STEWARD, J. H. The native population of South America. In: STEWARD, J. H. (Org.) Handbook of South American Indians. Washington: Government Printing Office, 1949. v.5. p.655-668.

VIDAL, L. Demografía dos grupos étnicos minoritários: Índios. Anais do III Encontro Nacional de Estudos Populacionais, p.405-407, Vitória: Associação Brasileira de Estudos Populacionais - Abep, 1982.

VIVEIROS DE CASTRO, E. B. Images of nature and society in Amazonian ethnology. Annual Review of Anthropology, 25:179-200, 1996.

WAGLEY, C. Os efeitos do despovoamento sobre a organização social entre os índios Tapirapé. Sociologia, IV:407-411, 1942.

WAGLEY, C. Cultural influences on population: a comparison of two Tupi tribes. Revista do Museu Paulista, 5:95-104, 1951.

WERNER, D. Fertility and pacification among the Mekranoti of Central Brazil. Human Ecology, 11:227-245, 1983a.

WERNER, D. Mudanças demográficas no Posto Indígena Ibirama. Anais do Museu de Antropologia da Universidade Federal de Santa Catarina, 15:24-33, 1983b.

WONG, L. R. Resumo das discussões sobre o tema "Etnia e População". Anais do IV Encontro Nacional de Estudos Populacionais, 3:1561-1563, Águas de São Pedro: Associação Brasileira de Estudos Populacionais - Abep, 1984.

WONG, L. R. A Dinâmica Demográfica dos Índios no Interior do Estado de São Paulo. [Relatório de pesquisa realizado com o auspício do Programa de Bolsas de Pesquisa da Associação Brasileira de Estudos Populacionais]. São Paulo: Associação Brasileira de Estudos Populacionais, 1986. (Mimeo.) 


\section{Povos Indígenas no Alto Rio Negro: um estudo de caso de nupcialidade}

\section{Introdução}

Diversos estudos sobre a demografia dos povos indígenas no Brasil relacionam componentes demográficos à estrutura social desses povos, como o de Pagliaro (2002), sobre os Kaiabi do Parque Indígena do Xingu, onde a autora relaciona os tipos de casamentos existentes com a organização social e a migração do grupo para o Xingu, demonstrando que muitas vezes constrangimentos demográficos podem causar rearranjos nos sistemas tradicionais de escolhas matrimoniais. Ao descrever os casamentos realizados entre homens kaiabi e mulheres juruna, suiá, trumai e txicão nos primeiros anos de permanência do grupo no Parque Indígena do Xingu, a autora avalia "... como estas uniões foram absorvidas pelo grupo, para que a reposição populacional não fosse ameaçada, mostrando como um problema demográfico pode modificar temporariamente arranjos familiares e culturais" (Pagliaro, 2002:153). Ainda sobre rearranjos matrimoniais, Laraia (1963) observa que entre os Suruí, após um longo período de depopulação causado por epidemias, uma mulher poderia estar casada com mais de um homem ao mesmo tempo, o que não era o comportamento tradicional deste grupo. O autor observa também que, na época em que trabalhou com os Suruí, muitas mulheres mantinham relações sexuais freqüentes com outros homens na ausência de seus maridos. A definição da paternidade social das crianças geradas a partir desses rearranjos variou, mas não o pertencimento aos clãs, que seguiu sendo pela via do marido da mãe, e não dos seus eventuais parceiros sexuais.

Trabalhos como os de Pozzobon (1994) sobre o mínimo populacional necessário para que uma determinada estrutura social possa se reproduzir, ou como o de Adams (1994), já relacionavam os padrões demográficos de nupcialidade aos tipos de organização social. Pozzobon descreve como uma população teórica, com uma estrutura social fundamentada em metades exogâmicas e determinada terminologia de parentesco, pode se reproduzir, e qual o número mínimo de pessoas necessário para esta reprodução. Adams em seu trabalho sobre os Caribe do rio 
Baráma, da Guiana Inglesa, discorre sobre rearranjos matrimoniais decorrentes de pressões demográficas causadas por questões econômicas e deslocamentos populacionais. Outro trabalho, como o de Coimbra Jr. et al. (2002) sobre a dinâmica demográfica dos Xavánte, relaciona as conseqüências de crises demográficas causadas pelo contato com os não-índios a fatores relativos à organização social deste povo.

A região do alto rio Negro, no lado brasileiro, é atualmente habitada por 21 povos indígenas ${ }^{1}$ falantes de línguas das famílias Tukano, Aruak e Maku. Faz fronteira com a Colômbia e Venezuela, e, em 1998, teve cinco terras indígenas (T.I.) homologadas: Alto Rio Negro, Médio Rio Negro I, Médio Rio Negro II, Apapóris e Tea. A região compreende o município de São Gabriel da Cachoeira e trechos do município de Santa Isabel e o de Japurá, localizados no estado do Amazonas. Apesar dos quase dois séculos de contato com a população não-índia, seus habitantes são majoritariamente indígenas e permanecem identificando-se como tais. Estima-se que a população atual desses povos seja cerca de 30 mil pessoas distribuídas por 600 comunidades/aldeias.

Motivada pelo processo de luta pela demarcação das terras indígenas, em 1992 a Federação das Organizações Indígenas do Rio Negro (Foirn), realizou um levantamento censitário das comunidades e populações da região. O Censo Indígena Autônomo do Rio Negro (Ciarn) levantou informações populacionais de 314 comunidades e da cidade de São Gabriel da Cachoeira, contabilizando 16.897 pessoas.

Aqui, são analisados os tipos de casamentos contabilizados pelo Ciarn, procurando testar as hipóteses sobre a exogamia lingüística e a proximidade geográfica, formuladas pelos estudos etnológicos sobre essa região.

\section{Casamento no alto rio Negro}

Os trabalhos antropológicos sobre casamento enfocam as trocas matrimoniais enquanto sistemas operados por categorias sociais definidas no interior de cada sociedade. As escolhas matrimoniais dos cônjuges são feitas com base em um sistema de parentesco, em que a própria terminologia já determina os círculos de parentes consangüíneos e afins. Dado que o Ciarn não pesquisou o parentesco mais amplo entre os diferentes grupos domésticos e entre os habitantes de diferentes comunidades, ${ }^{2}$ inviabilizando um estudo aprofundado de trocas matrimoniais, o presente texto descreve apenas os tipos de casamentos contabilizados, buscando dialogar com algumas hipóteses formuladas pelas teorias antropológicas sobre a região, especificamente aquelas relacionadas a alguns princípios da estrutura social e da proximidade geográfica, e analisar as relações entre estes dois princípios, em cada sub-região estudada. 
Na região do alto rio Negro o grupo lingüístico é interpretado em termos nativos como um conjunto de parentes agnáticos descendentes de um grupo de irmãos ancestrais míticos, e é este grupo lingüístico que na região é interpretado como povo ou tribo. ${ }^{3}$ Para todas as etnias dessa região, o casamento, do ponto de vista do homem, deve ocorrer com sua prima cruzada bilateral ${ }^{4}$ (filha da irmã do seu pai ou do irmão de sua mãe), caracterizando-se assim por uma terminologia de parentesco do tipo dravidiano. A regra de descendência é patrilinear, vale dizer, o pertencimento ao grupo lingüístico ou etnia, e conseqüentemente ao sib e fratria, ocorre por intermédio do pai. O casamento deve ocorrer ainda entre unidades sociológicas exogâmicas, isto é, existe na região uma ideologia que prescreve o casamento fora de seu grupo de origem.

As unidades sociais exogâmicas variam de acordo com as famílias lingüísticas. Para todos os povos da região, a mulher depois de casada deve residir na comunidade do marido, obedecendo à regra de virilocalidade. Apenas entre os povos falantes de línguas maku (Hupdë, Yupdë e Dow, no lado brasileiro) o casamento deve ocorrer valendo-se de uma ideologia endogâmica; mas, neste caso, dentro de um mesmo grupo lingüístico, a saber, preferencialmente um homem hupdë deve casar com uma mulher hupdë, ou quando não houver mulheres para se casar no seu grupo deve procurar por uma que seja de outra etnia maku.

Para os Tukano ${ }^{5}$ o casamento preferencial se dá com sua prima cruzada bilateral e que preferencialmente resida em comunidades próximas. Muitos autores que estudaram os povos dessa região chamaram a atenção para as alianças matrimoniais que incluem, além das regras de parentesco e exogamia, princípios geográficos. Århem (1989), que trabalhou com os Makuna (grupo tukano), enfatiza o casamento como estruturador de relações sociais e políticas importantes, demonstrando que este grupo se casa com afins próximos e estabelece com eles relações de aliança política, econômica e ritual. Goldman (1963), que estudou os Kubeo, frisa, ainda, o ambiente social multilíngüe dessa região, definido pela regra de exogamia lingüística e pelo mito de origem dos grupos tukano, que permite a inclusão de diferentes povos falantes de línguas distintas, fato que constituiria, segundo esse autor, um ambiente "aberto". Cabalzar $(1995,2000)$, que trabalha na região com os Tuyuka (grupo tukano), chama a atenção para o fato de que o casamento deve também ocorrer entre comunidades próximas. Este autor tece considerações sobre o conceito de "nexos regionais", que seriam microrregiões formadas por diversos grupos locais (que geralmente coincidem com as comunidades) conectados por relações políticas, rituais e econômicas (Cabalzar, 2000). Analisando o espaço social das comunidades tuyuka, Cabalzar dialoga com os trabalhos de Århem (1989), que formula a idéia de "grupos de aliança local" e Goldman (1963) que postula a fratria como um ambiente mais amplo, onde se difundem os mecanismos de exogamia. Goldman (1963) descreve o casamento kubeo como o 
único caso de endogamia lingüística entre todos os grupos tukano, mas a prescrição de exogamia segue existindo, sendo para este povo uma ocorrência entre fratrias, que seriam, cada uma delas, um grupo de sibs originários de irmãos ancestrais. $\mathrm{O}$ caso kubeo coincidiria, portanto, com o caso dos Baniwa (povo aruak). Este autor chama atenção para o fato de que a regra geográfica define uma certa proibição de casar-se dentro de uma mesma comunidade, mesmo no caso de haverem mulheres elegíveis. Porém, o casamento deve sempre ocorrer entre comunidades próximas, e a geografia pode definir a identidade da fratria, ou seja, quando um grupo pertencente a uma determinada fratria se muda de região, pode não ser mais identificado como pertencente à fratria original.

Sobre a relação entre o princípio da proximidade geográfica de comunidades de afins, Chernela (1983) chama a atenção para os limitantes ecológicos como definidores de regiões onde se poderiam estabelecer e permanecer diversas comunidades, o que faria, segundo a autora, com que as regras de casamento também estivessem condicionadas a esses fatores ecológicos. Outra autora que enfatiza o princípio geográfico da proximidade do casamento é C. HughJones (1979), que trabalhou com os Barasana e afirma que, sendo as comunidades tukano ribeirinhas, os trechos de rio formariam nexos sociológicos de comunidades de afins. A autora pondera ainda que, possivelmente, os grupos periféricos, ou seja, aqueles cujas comunidades se localizam em regiões mais distantes do rio Uaupés, são mais instáveis, podendo a unidade local ou o grupo lingüístico não coincidirem com as unidades exogâmicas. Nesse caso, as unidades exogâmicas poderiam ser mais inclusivas, pois numa mesma região geográfica existiria uma diversidade maior de povos e sibs. Jackson (1984), em estudo sobre os Bará, discorre sobre seu modelo que inclui diferentes grupos lingüísticos ou etnias em uma mesma fratria. Essa autora afirma que um Bará não deve se casar com um Tukano, apesar de serem etnias diferentes, porque pertenceriam a uma mesma fratria. Seria, como diz C. Hugh-Jones (1979), uma unidade exogâmica composta. Outra autora que faz referência ao princípio da proximidade geográfica é Buchillet (1992), que observou a tendência entre os Desana do rio Papuri de estabelecerem laços matrimoniais com comunidades vizinhas.

Entre os Baniwa e Coripaco, povos de línguas aruak, o casamento deve ser exogâmico, isto é, além de um homem casar com sua prima cruzada bilateral, ele deve casar fora de seu grupo social. A unidade exogâmica, porém, não é, como no caso dos tukano, o grupo lingüístico, mas a fratria. Baniwa é uma denominação que define um grupo lingüístico, considerado povo ou tribo na região e englobando os Coripaco, falantes de uma língua semelhante, em um nível sociopolítico mais amplo; logo, sem definir uma unidade exogâmica. As fratrias baniwa (denominadas Hohodene, Dzawinai, Waliperi Dakenai etc.) identificam grupos descendentes de irmãos ancestrais comuns e-são compostas por três ou mais sibs patrilineares. 
Esses sibs são ordenados hierarquicamente dentro de uma mesma fratria de acordo com a ordem de nascimento de seus irmãos ancestrais, da mesma maneira que para os tukano. O nome da fratria coincide com o nome do sib de mais alto grau na hierarquia, isto é, o grupo de indivíduos que descendem do irmão mais velho ancestral (Wright, 1981 e Buchillet, 1992)

As fratrias baniwa reconhecem um território comum, um trecho de rio onde as comunidades se localizam, e uma origem geográfica mítica comum; por exemplo, os Hohodene identificam a região da cachoeira do Uapuí, no alto rio Aiari, como seu lugar de origem. Esses trechos de rio são também compartilhados com as outras fratrias afins, vale dizer, comunidades de 'cunhados'.

Para os grupos falantes de línguas da família maku, cada grupo lingüístico divide-se em dois grupos patrilineares exogâmicos, não nomeados, e ligados entre si por laços de afinidade. E cada um desses grupos, por sua vez, subdividem-se em clãs patrilineares. Esses clãs encontram-se geograficamente dispersos em vários grupos locais, que são formados não por um grupo de irmãos como nas outras etnias, mas por grupos afins (Silverwood-Cope, 1990). Esses grupos locais são basicamente caçadores e coletores e habitam as cabeceiras e os intercursos dos rios e igarapés. Um grupo local em geral é constituído por um casal, cujo homem mais velho é a referência política do grupo, seus filhos solteiros e filhas casadas com seus esposos. O homem depois de casado, contrariamente aos outros grupos da região, deve residir temporariamente com seu sogro, obedecendo à regra de uxorilocalidade. Esses grupos locais são formados por vários grupos de fogos, ${ }^{6}$ unidos entre si por laços de afinidade, e sua composição não é estável, pode mudar por fusão com outro grupo local ou por fissão (Silverwood-Cope, 1990). Os povos maku são tradicionalmente endógamos, casam-se dentro de um mesmo grupo lingüístico ou com uma pessoa pertencente a uma outra etnia falante de língua maku.

De uma maneira geral, as comunidades dessa região do alto rio Negro são sempre localizadas nas margens dos $\operatorname{rios}^{7}$ e formadas por famílias conjugais (nucleares), chefiadas por membros do grupo local de descendência, geralmente pertencente a um mesmo sib de uma etnia. Por conseguinte, a comunidade é formada basicamente por homens irmãos casados, seus filhos e filhas solteiras. As mulheres vivem primeiramente com seus agnatas e depois do casamento vão morar com seus afins.

As comunidades geralmente trocam mulheres com outras comunidades identificadas localmente por "cunhados". ${ }^{8} \mathrm{O}$ casamento de um filho homem é preferencialmente acompanhado pelo de uma filha mulher, ou seja, a comunidade da família que casa um filho homem recebe uma mulher (sua esposa), e, ao mesmo tempo, entrega uma filha mulher para aquela comunidade de "cunhados" que entregou uma esposa para seu filho. Sendo assim, o casamento de um filho é acompanhado pela perda de uma filha. Desse modo, o casamento se dá preferencialmente por "pares" (Lasmar, 2002). 
Isso posto, os casamentos representam tanto um processo de fissão da família conjugal original quanto um processo de estabelecimento de alianças com outras comunidades. Cabalzar (1995:45) relata que no mito de origem tuyuka,

a transformação da 'Cobra de Pedra' em seres humanos; tornam-se freqüentes as referências às separações entre os diferentes povos qúe vieram do 'Lago do Leite', ao surgimento de línguas diferentes, e o que é mais importante, ao aparecimento da relação entre cunhados.

O casamento, portanto, representa uma força que pode desagregar o grupo de irmãos e agregar grupos de afins aliados políticos e rituais (Lasmar, 2002).

Nas análises feitas neste trabalho, são testadas as hipóteses da exogamia lingüística, para os Tukano, ${ }^{9}$ e da proximidade geográfica por trecho de rio e subregião. ${ }^{10}$ No caso dos povos baniwa e coripaco, não foi testada a hipótese de exogamia entre as diferentes fratrias, sendo apenas descritos os casamentos que ocorrem entre estes e outros povos ou internamente nestas mesmas etnias. São feitas análises por origem (nascimento) dos cônjuges e por sua residência no ano do Ciarn (1992). Para os povos de línguas maku não é feita distinção de etnia, pois estes estão identificados no Ciarn apenas como Maku, que é a maneira pela qual os Tukano identificam todas estas etnias. ${ }^{11}$ No caso dos Baré e Werekena, as duas outras etnias aruak, os casamentos também devem preferencialmente ocorrer dentro de seu próprio povo, sendo feita uma análise dos tipos de casamento por etnia e origem geográfica dos cônjuges.

Para efeito dessa pesquisa, a região do alto rio Negro foi dividida em cinco diferentes sub-regiões que foram delimitadas segundo critérios geográficos e sociológicos: Iauaretê, Tiquié/Uaupés, Içana, Negro Acima e Negro Abaixo.

A análise a seguir refere-se a 2.742 casais, distribuídos entre as subregiões conforme segue: 673 casais de Iauaretê; 565 do Tiquié/Uaupés; 587 do Içana; 375 do Negro Acima e 542 do Negro Abaixo. As comunidades de residência e de origem (nascimento) dos cônjuges foram classificadas conforme as sub-regiões e seus diferentes trechos de rios. As etnias são designadas por códigos que constam do Anexo I.

Será descrita a freqüência com que ocorrem as uniōes entre cônjuges de diferentes povos, ou seja, casos de exogamia lingüística, para as sub-regiões de Iauaretê e do Tiquié/Uaupés, prescrita para os povos tukano, tradicionais ocupantes dessas áreas. Para a região do Içana, de ocupação baniwa, são analisados os casamentos que ocorrem internamente à etnia e com outros povos. Nas subregiões do Negro Acima e Negro Abaixo, sendo a primeira de ocupação baré e werekena e a segunda de ocupação baré e região de destino de outros povos, são analisados os casamentos entre esses dois povos aruak, entre eles e os tukano, e entre os próprios tukano. 


\section{Mapa 1 - Sub-regiões no alto rio Negro}

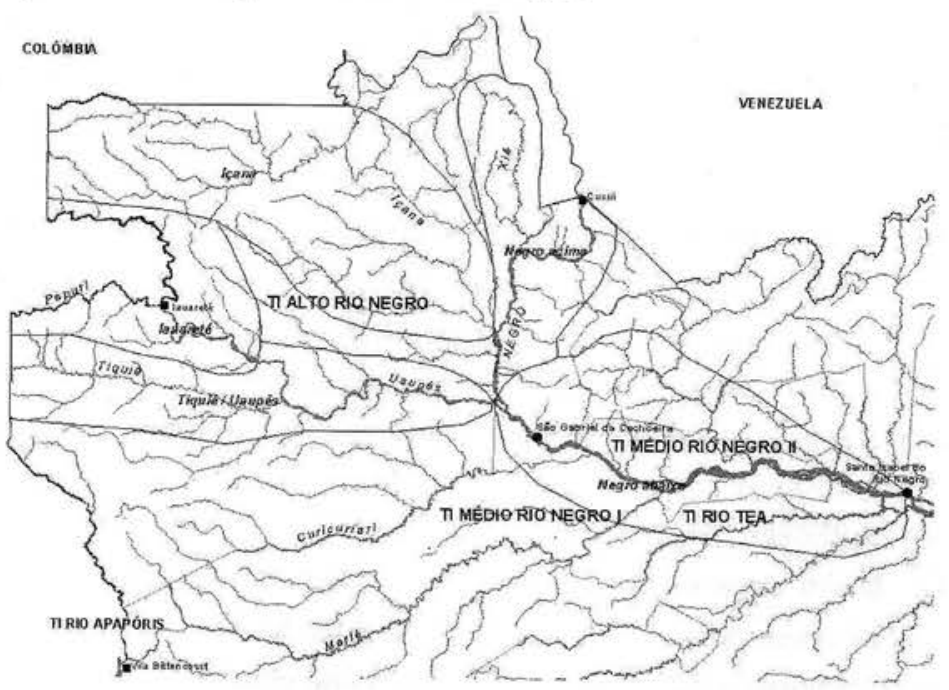

Para testar as hipóteses formuladas sobre o princípio da proximidade geográfica, as cinco sub-regiões foram subdivididas em trechos de rios ou centros missionários, conforme o Anexo II. Estes trechos de rios são contíguos e as microrregiões onde se localizam as comunidades que trocam cônjuges muitas vezes estão situadas nos limites entre os diferentes trechos de rios. Desta forma, nem todas as 'microrregiões de troca' 12 foram delimitadas e demonstradas, seria preciso fazer estudos por comunidade e geo-referenciar as informações de casamento. Estão também identificados os países vizinhos, Colômbia e Venezuela, como lugares de origem dos cônjuges nascidos em comunidades vizinhas, dado que se trata de uma região de fronteira, ocupada por povos indígenas de áreas localizadas nestes dois países. Para identificar os cônjuges nascidos em sub-regiões distintas daquela estudada, utiliza-se o termo genérico 'fora'. Somente no caso das análises por origem geográfica da sub-região do Negro Abaixo são identificadas cada uma das outras sub-regiões como de origem dos cônjuges, por ser esta uma região de destino de migrações.

\section{Casamentos por etnia}

\section{- Sub-região de Iauaretê}

Iauaretê é habitada tradicionalmente pelos Tariana desde o trecho mais alto do rio Uaupés, até o começo do Papuri, encontrando-se ainda comunidades deste povo do médio rio Uaupés até a comunidade de Urubuquara. Os outros povos que ocupam a região e que estabelecem redes de trocas, das quais os casamentos fazem parte, são os Tukano, Piratapuia, Desana, Kubeo e outros falantes de línguas tukano. 
No momento da realização do Ciarn (1992), a maioria dos homens tariana estava casada com mulheres tukano; seguindo-se as uniões com mulheres piratapuia, além do pequeno número de uniões com mulheres de outros grupos tukano (Tabela 1). Chama-se a atenção para o fato de que os povos majoritários nas duas sub-regiões habitadas pelos tukano (Iauaretê e Tiquié/Uaupés) casam-se com mulheres pertencentes a um número maior de etnias. Porém, sempre ocorre uma preferência por duas ou três etnias, fato que fica demonstrado pelo elevado número de homens tariana casados com mulheres tukano ou piratapuia.

Os homens tukano, segunda etnia em tamanho nesta sub-região e uma das mais populosas da região do rio Negro, casam-se em maior número com mulheres tariana, seguindo-se a preferência por mulheres desana. A maioria dos Desana casa-se com mulheres tukano e wanana.

Os Maku casam-se entre si, confirmando a regra da preferência de casamento para estes povos. Os Kubeo também estão em sua maioria casados com mulheres pertencentes a esta etnia, com exceção de cinco homens que estão casados com mulheres wanana, povo que vive em comunidades próximas, e três casados com mulheres tariana e desana, sendo estas, provavelmente, habitantes de comunidades mais distantes geograficamente. A regra de casamento kubeo descrita por Goldman (1963) é observada nestes casos relatados.

Os casamentos endogâmicos não prescritos referem-se a cinco homens tariana casados com mulheres desta mesma etnia, e a cinco tukano e três wanana casados com mulheres consideradas parentes.

O esquema apresentado na Figura 1 procura descrever as trocas havidas entre etnias, sempre tomando como referência os homens. Deve-se ler da seguinte maneira: um homem tariana (TA) casa-se majoritariamente (flecha mais grossa em direção aos TU) com mulheres tukano, e em segundo lugar casa-se com mulheres piratapuia (flecha mais fina em direção aos PI). A direção da flecha neste esquema indica os homens indo se casar com mulheres das outras etnias. Pode-se notar que os Tariana são os que mais trocam mulheres, casando-se preferencialmente com os Tukano e Piratapuia, e 'doando' mulheres para muitos outros grupos diferentes. A Tabela 1 mostra que os Tariana são o povo que se casa com um maior número de etnias, seguidos dos Tukano. No caso dos Tariana, possivelmente se estabelecem as trocas duplas relatadas na literatura antropológica, pois tanto recebem mulheres tukano e piratapuia, quanto enviam mulheres tariana para estes povos.

Poderíamos dizer que, entre os povos tukano, os casamentos das etnias que tradicionalmente habitam uma determinada região serão formados por alianças com um número maior de etnias, estabelecendo relações sociais, políticas, econômicas e rituais com um maior número de comunidades. Os casamentos desta sub-região são quase todos exogâmicos, entre etnias diferentes, com exceção dos Maku e Kubeo, mas a exogamia lingüística é relativizada pela preferência por uma determinada 
proximidade geográfica, o que se comprova com o casamento de homens do Uaupés Acima com mulheres da região do Aiari ou Içana (Baniwa ou Coripaco).

Figura 1 - Trocas interétnicas em Iauaretê

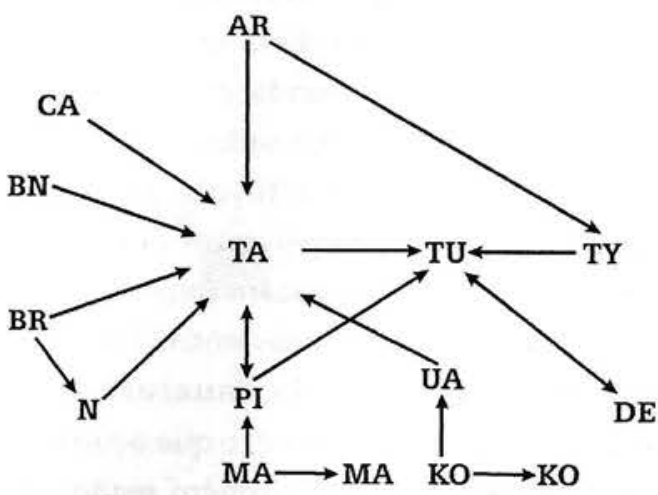

Tabela 1 - Casamentos por etnia, dos residentes na sub-região de Iauaretê

\begin{tabular}{|c|c|c|c|c|c|c|c|c|c|c|c|c|c|c|c|c|c|c|}
\hline \multirow[b]{2}{*}{ Homens } & \multicolumn{18}{|c|}{ Mulheres } \\
\hline & AR & BS & $\mathrm{BN}$ & $\mathrm{BR}$ & $\mathrm{CA}$ & $\mathrm{CO}$ & $\mathrm{DE}$ & JU & KO & MA & MI & $\mathrm{N}$ & PI & TA & TU & TY & UA & Total \\
\hline $\mathrm{AR}$ & - & - & - & - & - & - & 1 & - & - & - & - & - & - & 15 & 9 & - & - & 25 \\
\hline $\mathrm{BN}$ & - & - & - & - & - & - & - & - & - & - & - & - & - & 2 & - & - & - & 2 \\
\hline BR & - & - & - & - & - & - & - & - & - & - & - & 1 & - & 1 & - & - & - & 2 \\
\hline $\mathrm{CA}$ & - & - & - & - & - & - & - & - & - & - & - & - & - & 1 & - & - & - & 1 \\
\hline $\mathrm{DE}$ & 1 & - & - & 1 & - & - & - & 1 & - & - & - & - & 6 & 2 & 23 & - & 9 & 43 \\
\hline KO & - & - & 1 & - & - & 1 & 3 & - & 12 & - & - & - & - & 3 & - & 1 & 5 & 26 \\
\hline MA & - & - & - & - & - & - & - & - & - & 78 & - & - & 3 & & - & - & - & 81 \\
\hline $\mathrm{N}$ & - & - & - & - & - & - & - & - & - & - & - & 1 & 1 & 5 & - & - & 1 & 8 \\
\hline PI & - & - & - & - & - & - & 16 & 1 & 1 & 2 & - & - & - & 32 & 18 & - & 2 & 72 \\
\hline $\mathrm{TA}$ & 10 & 1 & 2 & 4 & 2 & - & 5 & 1 & 5 & - & 1 & 1 & 59 & 5 & 83 & 3 & 14 & 196 \\
\hline TU & 8 & 1 & - & - & 1 & - & 30 & 1 & - & 3 & - & - & 15 & 57 & 5 & 12 & 7 & 140 \\
\hline TY & - & 1 & - & - & - & - & 1 & - & - & - & - & - & - & 1 & 9 & - & - & 12 \\
\hline UA & 1 & - & 6 & 1 & 1 & 1 & 12 & - & 9 & - & - & - & - & 20 & 8 & 3 & 3 & 65 \\
\hline Total & 20 & 3 & 9 & 6 & 4 & 2 & 68 & 4 & 27 & 83 & 1 & 3 & 84 & 144 & 155 & 19 & 41 & 673 \\
\hline
\end{tabular}

endogamia considerada incesto endogamia permitida

Fonte: Ciarn. 
- Sub-região do Tiquié/Uaupés

Esta sub-região é habitada majoritariamente pelos Tukano, Desana e Tuyuka. No momento de realização do Ciarn, os Tukano da região estavam casados, em sua maioria, com mulheres desana, seguindo-se as mulheres tuyuka, principalmente no trecho do alto rio Tiquié. Os casamentos tuyuka também ocorrem em maior número com mulheres tukano. Essa grande freqüência de casamentos tuyuka com tukano foi largamente analisada por Cabalzar (2000), conforme já mencionado anteriormente, e os dados analisados na Tabela 2 vêm confirmar que os Tukano são os cunhados preferenciais dos Tuyuka, pelo menos do lado brasileiro. A Figura 2 representa as trocas de mulheres entre os diferentes povos desta subregião, e mostra que as duas etnias que trocam majoritariamente mulheres entre si são Tukano e Desana, seguidas pelas trocas entre Tuyuka e Tukano.

Assim como na sub-região de Iauaretê, os Desana casam-se majoritariamente com os Tukano (e vice-versa), o que ocorre também na sub-região do Negro Abaixo, onde estes dois povos também estão presentes. Os Tariana, presentes em número pequeno nesta sub-região, aqui também se casam com mulheres tukano e piratapuia, repetindo o tipo de casamento encontrado em Iauaretê.

Os Maku, habitantes tradicionais dos intercursos dos rios e de comunidades situadas em igarapés afluentes do Tiquié, estão representados por 114 homens e 116 mulheres. Entre os homens, apenas um está casado com uma mulher tukano, e entre as mulheres, somente três casaram-se com homens desana. Assim como na sub-região de Iauaretê, no Tiquié/Uaupés também se confirma a regra de casamento preferencial dos Maku com povos falantes desta família lingüística.

Os únicos casos de endogamia lingüística tukano, ou seja, de uniões consideradas incestuosas pela regra tradicional, são os de 14 homens casados com mulheres tukano, três homens desana casados com mulheres desana e 1 homem mirititapuia casado com uma mulher da mesma etnia.

No esquema (Figura 2), as possíveis trocas duplas se dão entre os Tukano e Desana, os Tuyuka e Tukano e os Desana e Tukano. Existe também um pequeno número de trocas entre os Tuyuka e Desana. Estes casamentos podem ser considerados como geograficamente próximos, visto que estas etnias estão localizadas, principalmente, em comunidades do Tiquié. 
Tabela 2 - Casamentos por etnia, dos residentes na sub-região do Tiquié/Uaupés.

\begin{tabular}{|c|c|c|c|c|c|c|c|c|c|c|c|c|c|c|c|c|c|c|}
\hline \multirow[b]{2}{*}{ Homens } & \multicolumn{18}{|c|}{ Mulheres } \\
\hline & $\mathrm{AR}$ & $\mathrm{BN}$ & BR & BS & $\mathrm{CA}$ & $\mathrm{CO}$ & $\mathrm{DE}$ & KO & MA & MI & MK & $\mathrm{N}$ & PI & TA & $\mathrm{TU}$ & TY & UA & Total \\
\hline AR & - & - & - & - & - & - & 1 & - & - & - & - & - & - & - & 1 & - & - & 2 \\
\hline BA & - & - & - & - & - & - & 2 & - & - & - & - & - & - & - & 1 & - & - & 3 \\
\hline BR & - & 1 & - & - & - & - & 1 & - & - & - & - & - & - & - & 1 & - & - & 3 \\
\hline BS & - & - & - & - & - & - & - & - & - & - & - & - & - & - & - & 1 & - & 1 \\
\hline $\mathrm{CA}$ & - & - & - & - & - & - & 2 & - & - & - & - & - & - & - & - & - & - & 2 \\
\hline $\mathrm{DE}$ & 2 & - & - & - & - & - & 3 & - & 3 & 5 & 2 & - & 5 & 2 & 77 & 10 & - & 109 \\
\hline MA & - & - & - & - & - & - & - & - & 113 & - & - & - & - & - & 1 & - & - & 114 \\
\hline MI & - & - & - & - & 1 & - & 2 & - & - & 1 & - & - & - & 1 & 12 & 2 & - & 19 \\
\hline MK & - & - & - & - & - & - & 1 & - & - & - & 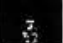 & - & - & - & - & 4 & - & 5 \\
\hline N & - & - & - & - & - & - & 1 & - & - & - & - & - & 1 & - & 1 & - & - & 3 \\
\hline PI & & 1 & & & & & 5 & & & & & & - & 5 & 13 & & & 24 \\
\hline TA & 2 & - & - & - & - & 1 & 3 & - & - & - & - & - & 4 & - & 6 & 3 & 2 & 21 \\
\hline $\mathrm{TU}$ & 3 & 1 & 1 & - & - & - & 76 & 1 & 2 & 8 & - & 1 & 15 & 21 & 14 & 59 & 2 & 204 \\
\hline TY & - & - & - & 6 & - & - & 5 & - & 3 & 2 & 2 & - & 2 & - & 35 & - & - & 55 \\
\hline Total & 7 & 3 & 1 & 6 & 1 & 1 & 102 & 1 & 121 & 16 & 4 & 1 & 27 & 29 & 162 & 79 & 4 & 565 \\
\hline
\end{tabular}

endogamia considerada incesto endogamia permitida

Fonte: Ciarn.

Figura 2 - Trocas matrimoniais entre etnias na sub-região do Tiquié/ Uaupés.

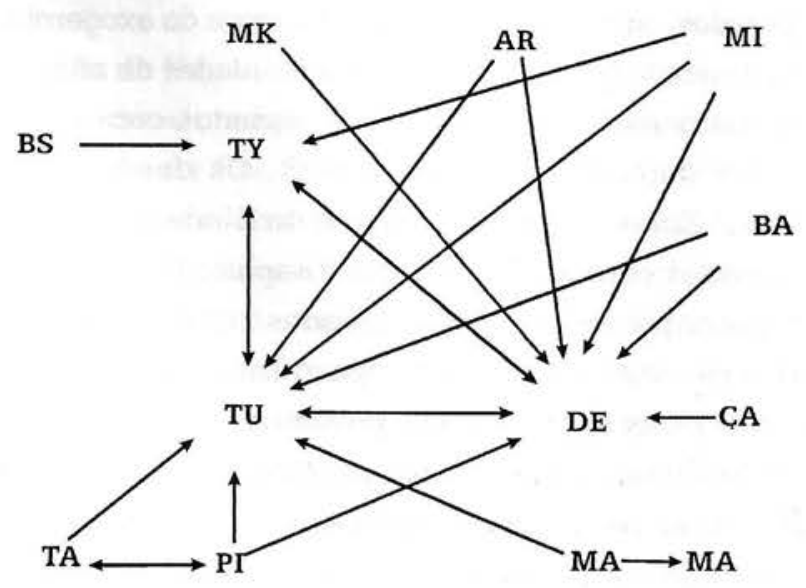


De uma maneira geral, nestas duas sub-regiões analisadas, onde tradicionalmente vivem os povos tukano, a exogamia lingüística é estritamente observada, ocorrendo poucos casos de endogamia não permitida. Observa-se ainda que cada povo tem um maior número de ocorrências de casamentos com alguns outros povos, o que se demonstra nos esquemas quando as flechas estão nas duas direções. Podemos concluir, ainda, que as etnias majoritárias em termos de tamanho de população, que habitam tradicionalmente cada uma destas duas sub-regiões, casam-se com um maior número de diferentes etnias, ampliando assim seu leque de alianças políticas, econômicas e rituais.

É interessante notar que nessas duas sub-regiões, Iauaretê e Tiquié/ Uaupés, o casamento entre etnias que se consideram 'parentes' ou como pertencendo a uma grande fratria (Jackson, 1984) ou como unidades exogâmicas compostas (Hugh-Jones, 1979) não ocorre de maneira expressiva.

- Sub-região do Içana

Trata-se da região onde estão localizadas as comunidades baniwa, que se estendem pelos rios Içana, Aiari, Cuiari e também estão presentes na sub-região do Negro Abaixo, tendo migrado até às cidades de Santa Isabel e Barcelos.

Os povos baniwa e coripaco são os mais populosos dessa região do alto rio Negro, estando presentes também na Colômbia e Venezuela. Os Coripaco habitam as comunidades do alto rio Içana, e predominam na Colômbia. Falam uma língua muito semelhante ao Baniwa, com algumas variações dialetais. O casamento desses dois povos deve ocorrer no interior das etnias, sendo a exogamia prescrita no nível das fratrias, segundo já foi explicado antes. Os Baniwa casam-se também com os Kubeo e Wanana, em virtude da proximidade geográfica de suas comunidades localizadas no trecho do rio Uaupés acima de Iauaretê. Conforme já mencionado, esses casamentos, ainda que não esperados, caso se conside apenas a regra da exogamia, acontecem pela preferência da proximidade geográfica entre comunidades de afins.

Dos 444 homens baniwa, 388 estão casados com mulheres da mesma etnia, conforme fica demonstrado na Tabela 3. Os demais estão casados com Coripaco, Werekena, Kubeo e Wanana, restando ainda um pequeno número de homens baniwa casados com as Tariana, Mirititapuia, Desana, Arapaso, Tukano e não-índio. Os Coripaco, por sua vez, estão casados, maciçamente, com mulheres da mesma etnia. Há, além disso, homens coripaco casados com mulheres baniwa, e vice-versa. Os homens das demais etnias presentes na sub-região são casados em grande parte com mulheres baniwa, salvo os Baré, majoritariamente casados com mulheres de sua própria etnia. Os 20 homens werekena presentes na sub-região, estão casados com mulheres baniwa, possibilitando dessa maneira a criação de uma rede de relações de troca com a etnia majoritária desta sub-região. 
Como nas duas sub-regiões anteriores, são os Baniwa que se casam com um maior número de etnias, 10 etnias distintas, excluindo-se eles próprios e os não-índios. Os Coripaco, outro povo tradicional desta sub-região, casam-se apenas entre si ou com os Baniwa, encontrando-se apenas um homem coripaco que está casado com uma mulher kubeo.

Tabela 3 - Casamentos por etnia, dos residentes na sub-região do Içana

\begin{tabular}{cccccccccccccc} 
& \multicolumn{10}{c}{ Mulheres } \\
\hline Homens & AR & BN & BR & CO & DE & KO & MI & N & TA & TU & UA & EU & Total \\
\hline BN & 1 & 388 & 8 & 16 & 1 & 10 & 2 & 1 & 7 & 1 & 8 & 13 & 456 \\
BR & - & 6 & 7 & 1 & - & - & - & - & 1 & - & - & 3 & 18 \\
CA & - & 1 & - & - & - & - & - & - & - & - & - & - & 1 \\
CO & - & 16 & - & 43 & - & 1 & - & - & - & - & - & - & 60 \\
DE & - & 4 & - & - & - & - & - & - & - & 1 & 2 & - & 7 \\
KO & - & 3 & - & 1 & - & 1 & - & - & - & - & - & - & 5 \\
N & - & - & - & 1 & 1 & - & - & - & - & - & - & - & 2 \\
TA & - & 3 & 1 & - & - & - & - & - & - & - & - & 3 & 7 \\
TU & - & 4 & - & - & - & - & - & - & - & - & 1 & - & 5 \\
TY & - & 1 & - & - & - & - & - & - & - & 1 & - & - & 2 \\
UA & - & 3 & - & - & - & - & - & - & - & 1 & - & - & 4 \\
UE & - & 15 & 1 & - & - & 1 & - & - & 2 & - & - & 1 & 20 \\
\hline Total & 1 & 444 & 17 & 62 & 2 & 13 & 2 & 1 & 10 & 4 & 11 & 20 & 587 \\
\hline
\end{tabular}

endogamia considerada incesto

endogamia permitida

Fonte: Ciarn.

- Sub-região do Negro Acima

As comunidades situadas nas margens do rio Negro, desde a fronteira com a Venezuela até a região da Ilha das Flores, cerca da foz do Uaupés, são em sua maioria habitadas pelos Baré. Essa sub-região é a única dentre as estudadas que possui um trecho do rio Negro (que vai desde a comunidade de Vista Alegre, até a fronteira com a Venezuela) fora das terras indígenas demarcadas (margem esquerda do rio Negro, ver Mapa 1). Os Baré tradicionalmente falavam uma língua aruak, que foi paulatinamente sendo substituída pelo nheengatu, língua geral introduzida pelos missionários e falada também pelos Werekena, que mantêm sua língua original.

Por ocasião da realização do Ciarn, os Baré estavam majoritariamente casados entre si (Tabela 4), seguindo-se os casamentos com mulheres werekena na região do baixo rio Xié, e com mulheres baniwa, na região do baixo Içana. Os homens werekena estavam majoritariamente casados com mulheres da mesma 
etnia, seguindo-se as uniões com os Baré e os Baniwa. Portanto, nesta sub-região, os casamentos também ocorrem de acordo com a prescrição, vale dizer, os dois povos majoritários preferencialmente devem se casar com mulheres falantes da mesma língua. Os Baniwa aí residentes seguem a mesma tendência de casamento observada na sua sub-região de ocupação tradicional, casando-se preferencialmente entre si.

Vale notar que, como ocorre nas outras três sub-regiões, a etnia predominante nesta região - os Baré - é a que se casa com um maior número de povos distintos.

Tabela 4 - Casamentos por etnia, dos residentes na sub-região do Negro Acima

\begin{tabular}{cccccccccccccc}
\hline & \multicolumn{10}{c}{ Mulheres } \\
\cline { 2 - 12 } Homens & AR & BN & BR & CO & DE & PI & TA & TU & TY & UA & EU & Total \\
\hline AR & - & - & - & - & 2 & 1 & 2 & 4 & - & - & - & 9 \\
BN & - & 18 & 12 & 1 & - & - & 2 & 2 & - & - & 6 & 41 \\
BR & 1 & 16 & 185 & 3 & 1 & - & - & 5 & - & 1 & 18 & 230 \\
CO & - & 2 & 1 & - & - & - & - & 1 & - & - & - & 4 \\
DE & - & - & 1 & - & - & 1 & - & 3 & - & - & - & 5 \\
N & - & 1 & 10 & - & - & - & 1 & - & - & - & - & 12 \\
PI & - & - & 2 & - & 1 & - & - & 1 & - & - & - & 4 \\
TA & 1 & 2 & 2 & - & - & 1 & - & 1 & - & - & 1 & 8 \\
TU & 2 & 1 & - & - & - & 1 & 2 & 2 & 1 & - & 3 & 12 \\
TY & - & 1 & - & - & - & - & - & - & - & - & - & 1 \\
UE & 1 & 8 & 8 & 1 & - & - & 1 & 2 & - & - & 28 & 49 \\
\hline Total & 5 & 49 & 221 & 5 & 4 & 4 & 8 & 21 & 1 & 1 & 56 & 375 \\
\hline
\end{tabular}

endogamia considerada incesto endogamia permitida

Fonte: Ciarn.

\section{- Sub-região do Negro Abaixo}

Esta sub-região é onde se localiza a cidade de São Gabriel da Cachoeira, sede do município, e região de destino de migração de muitas famílias indígenas, sejam tukano, ou aruak. Assim como a sub-região do Negro Acima é área de ocupação tradicional dos Baré, etnia ainda preponderante, por mais que exista um número expressivo de índios de outras etnias vivendo em comunidades desta subregião, e na cidade de São Gabriel da Cachoeira.

Os Baré desta região estavam casados na sua maioria com mulheres deste mesmo povo (Tabela 5); todavia, diferentemente do que ocorre na sub-região do Negro Acima, os homens baré se casam em segundo lugar com mulheres tukano e desana (e não com Werekena), estabelecendo alianças com mulheres oriundas das 
famílias destes povos que migraram para esta região. Os Tukano estão casados majoritariamente com mulheres desana, assim como já visto na sub-região do Tiquié/Uaupés. Este casamento também é muito expressivo em Iauaretê, apenas antecedido pelo casamento de homens tukano com mulheres tariana. Os Tariana também seguem o mesmo tipo de preferência de casamento de sua região tradicional, isto é, com mulheres tukano ou piratapuia, além de ocorrerem casamentos com outros grupos, incluindo seis casos de casamentos com Arapaso, situação igualmente observada em Iauaretê. Nesse sentido, é possível supor que os Tukano, que não são originários desta sub-região, tenham se casado antes de migrar ou continuem obedecendo às mesmas regras de preferência de casamento. A regra da exogamia lingüística parece permanecer operante, apesar de existir um número maior de homens tukano casados com mulheres desta mesma etnia.

Da mesma forma que nas outras quatro sub-regiões estudadas, a etnia prevalecente é que se casa com um maior número de povos distintos. Neste caso são os Baré, que estão casados com 12 povos diferentes, excluindo-se os não-índios.

Tabela 5 - Casamentos por etnia, dos residentes na sub-região do Negro Abaixo

\begin{tabular}{|c|c|c|c|c|c|c|c|c|c|c|c|c|c|c|c|c|c|}
\hline \multirow[b]{2}{*}{ Homens } & \multicolumn{17}{|c|}{ Mulheres } \\
\hline & AR & $\mathrm{BN}$ & BR & $\mathrm{CA}$ & $\mathrm{CO}$ & $\mathrm{DE}$ & KO & MA & MI & $\mathrm{N}$ & PI & $\mathrm{TA}$ & TU & TY & UA & UE & Total \\
\hline AR & - & 1 & - & - & - & 2 & - & - & - & - & - & 1 & 3 & - & - & - & 7 \\
\hline BN & 2 & 37 & 5 & - & 1 & 4 & 1 & - & - & - & - & 1 & 2 & 1 & - & - & 54 \\
\hline$B R$ & 1 & 8 & 99 & 1 & 1 & 17 & 2 & - & - & 3 & 5 & 8 & 30 & 1 & 2 & - & 178 \\
\hline $\mathrm{CA}$ & - & - & - & - & - & 1 & - & - & - & - & - & - & - & - & - & - & 1 \\
\hline $\mathrm{DE}$ & 1 & 10 & 7 & - & - & 1 & - & 1 & - & 1 & 11 & 7 & 34 & 1 & - & 1 & 75 \\
\hline JU & - & - & - & 1 & - & - & - & - & - & - & - & - & - & - & - & - & 1 \\
\hline KO & - & - & - & - & - & 1 & - & - & - & - & - & - & - & - & - & - & 1 \\
\hline MA & - & - & - & - & - & - & - & 15 & - & - & - & - & - & - & - & - & 15 \\
\hline $\mathrm{N}$ & 2 & 2 & 3 & - & - & - & - & - & - & 2 & - & - & 2 & 1 & - & - & 12 \\
\hline PI & 1 & 2 & 2 & - & - & 5 & - & - & - & - & 3 & 9 & 12 & 1 & - & - & 35 \\
\hline TA & 6 & 2 & 4 & - & - & 3 & - & - & - & 1 & 6 & 3 & 11 & 1 & - & - & 37 \\
\hline $\mathrm{TU}$ & 7 & 8 & 6 & 2 & - & 23 & - & 2 & 2 & - & 18 & 21 & 22 & 2 & - & - & 113 \\
\hline TY & - & - & - & - & - & 2 & - & - & - & - & - & - & 4 & - & - & - & 6 \\
\hline UA & - & 3 & 1 & - & - & 2 & - & - & - & - & - & - & 1 & - & - & - & 7 \\
\hline Total & 20 & 73 & 127 & 4 & 2 & 61 & 3 & 18 & 2 & 7 & 43 & 50 & 121 & 8 & 2 & 1 & 542 \\
\hline
\end{tabular}

endogamia considerada incesto endogamia permitida

Fonte: Ciarn. 


\section{Casamentos por microrregiões}

- Sub-região de Iauaretê

Os 673 casais da sub-região estão distribuídos por trecho de rio de nascimento, denominado por origem geográfica (Tabela 6). A maior parte dos 611 homens que reside nesta sub-região é originária da área. As mulheres nascidas na Colômbia ou fora, residentes na sub-região, são mais numerosas do que os homens dessas localidades. A maioria é originária da sub-região de Iauaretê. Na Tabela 6 é possível observar que a maior parte dos homens originários dos trechos de rios desta sub-região está casada com mulheres desses mesmos trechos de rio. A única exceção é em Iauaretê Centro, onde a maior parte dos homens está casada com mulheres do Papuri.

Esse tipo de análise possibilitou também avaliar a proporção de homens e mulheres que após o casamento continuam na sub-região de residência. No trecho de rio do Uaupés, $75 \%$ dos homens e $58 \%$ das mulheres permanecem na região onde residiam antes do casamento. Estas proporções variam por trecho de rio; contudo, a tendência se mantém favorável ao sexo masculino. A foz deste rio no Uaupés possivelmente forma outra microrregião de trocas matrimoniais, que se sobrepõe ao trecho de rio Uaupés. A existência de casamentos fora das microrregiões de troca indica que elas se sobrepõem. A Colômbia pode ser considerada no caso dos trechos dos rios Uaupés Acima e Papuri como parte das microrregiões de troca, uma vez que a margem direita do Uaupés e a esquerda do Papuri, já neste país, são ocupadas por comunidades que fazem parte das redes de trocas com as comunidades localizadas do lado brasileiro.

Tabela 6 - Sub-região de Iauaretê - casamentos por origem geográfica dos cônjuges

\begin{tabular}{cccccccc}
\hline & \multicolumn{9}{c}{ Mulheres } \\
\cline { 2 - 8 } Homens & $\begin{array}{c}\text { Iauareté } \\
\text { Centro }\end{array}$ & Uaupés & $\begin{array}{c}\text { Uaupés } \\
\text { Acima }\end{array}$ & Colômbia & Papuri & fora & Total \\
\hline $\begin{array}{c}\text { Iauareté } \\
\text { Centro }\end{array}$ & 8 & 15 & 15 & 7 & 16 & 6 & 67 \\
$\begin{array}{c}\text { Uaupés } \\
\text { Uaupés } \\
\text { Acima }\end{array}$ & 14 & 80 & 14 & 12 & 35 & 21 & 176 \\
Colômbia & 2 & 12 & 67 & 23 & 30 & 29 & 167 \\
Papuri & 14 & 29 & 20 & 36 & 86 & 16 & 201 \\
fora & 2 & 11 & 3 & 3 & 12 & 14 & 45 \\
\hline Total & 46 & 149 & 122 & 87 & 182 & 87 & 673 \\
\hline
\end{tabular}

casamento fora da microrregião casamento dentro da microrregião

Fonte: Ciarn. 
O caso dos três centros missionários e da área urbana de São Gabriel da Cachoeira é distinto dos diferentes trechos de rios. Os casamentos contabilizados pelo Ciarn, em 1992, estavam organizados de maneira a continuar com os mesmos tipos de trocas entre as diferentes etnias, mantendo-se a diferença entre a proporção de homens que nascem e ficam nestes centros missionários/urbanos e mulheres que se casam e acabam se mudando de lugar. Situação análoga foi observada por Jackson (1984) em seu trabalho sobre os Bará, indivíduos originários de centros missionários, por serem locais de migração de famílias oriundas de distintas comunidades, não mantinham a preferência pela proximidade geográfica de casamento. Iauaretê Centro é originário de uma missão salesiana, instalada em uma área de ocupação tradicional dos Tariana, onde duas grandes aldeias deste povo existiam, e ainda se mantêm como bairros deste povoado.

- Sub-região do Tiquié/Uaupés

Nesta sub-região residem 565 casais, distribuídos por três trechos de rios e dois povoados. A maior parte dos homens é nascida na sub-região, e os restantes são 53 homens nascidos em outras sub-regiões, e sete homens nascidos em comunidades vizinhas na Colômbia.

Na Tabela 7, é possível verificar que os homens nascidos no Alto Tiquié e Pari Cachoeira Centro são casados majoritariamente com mulheres deste mesmo trecho de rio. Nos outros dois trechos de rio, Baixo Tiquié e Uaupés, os homens se casam com mulheres do Alto Tiquié e de fora, respectivamente. Na Tabela 7, estão marcados com cinza os casamentos próximos e com preto os que podem ser considerados casamentos distantes.

Tabela 7 - Sub-região do Tiquié/Uaupés - casamentos de residentes por origem geográfica dos cônjuges

\begin{tabular}{ccccccccc}
\hline & \multicolumn{7}{c}{ Mulheres } \\
\cline { 2 - 10 } Homens & $(1)$ & $(2)$ & $(3)$ & $(4)$ & $(5)$ & $(6)$ & $(7)$ & Total \\
\hline Uaupés (1) & 15 & 1 & 11 & 5 & 2 & 26 & 2 & 62 \\
Baixo Tiquié (2) & 2 & 13 & 21 & 1 & 1 & 3 & 2 & 43 \\
Alto Tiquié (3) & 8 & 17 & 244 & 27 & 2 & 25 & 15 & 338 \\
Pari Cachoeira Centro (4) & 2 & - & 27 & 6 & - & 5 & 1 & 41 \\
Taracuá Centro (5) & 4 & 4 & 3 & 1 & 1 & 6 & 2 & 21 \\
fora (6) & 9 & 4 & 16 & 2 & 3 & 18 & 1 & 53 \\
Colômbia (7) & - & - & 3 & - & - & 1 & 3 & 7 \\
\hline Total & 40 & 39 & 325 & 42 & 9 & 84 & 26 & 565 \\
\hline
\end{tabular}

casamento fora da microrregião casamento dentro da microrregião

Fonte: Ciarn. 
Em todos os trechos de rios do Tiquié e do Uaupés os homens permanecem residindo na sua microrregião de origem em uma proporção de aproximadamente 80 a $90 \%$; as mulheres numa proporção de cerca de $50 \%$.

- Sub-região do Içana

Esta sub-região é tradicionalmente ocupada pelos povos baniwa e coripaco, e no baixo rio Içana existem ainda algumas comunidades baré. A maior parte dos homens e mulheres aí nascidos continua a residir nesta mesma sub-região após o casamento. Entre os homens e mulheres não-naturais dessa sub-região, a maioria vem de outras sub-regiões do Brasil, e uma pequena parcela vem da Colômbia e Venezuela. Pode-se observar, na Tabela 8, que os homens naturais dos três trechos de rios desta sub-região estão casados com mulheres naturais destas mesmas microrregiões; somente o centro missionário de Assunção é que foge à regra.

Da mesma forma que nas outras duas sub-regiões anteriormente analisadas, os homens permanecem em proporção de quase $90 \%$ no seu trecho de rio de origem, e as mulheres permanecem em uma proporção de cerca de $50 \%$. Em Assunção do Içana, centro missionário de formação mais recente do que Iauaretê e Pari Cachoeira, os casais estudados são em sua maioria naturais do baixo Içana e Aiari; nesse caso, também os homens originários desse centro permanecem na sub-região em proporção maior do que as mulheres.

Tabela 8 - Sub-região do Içana - casamentos dos residentes por origem geográfica dos cônjuges

\begin{tabular}{ccccccccc}
\hline & \multicolumn{7}{c}{ Mulheres } \\
\cline { 2 - 9 } Homens & $(1)$ & $(2)$ & $(3)$ & $(4)$ & $(5)$ & $(6)$ & $(7)$ & Total \\
\hline Assunção Centro (1) & 1 & 2 & 1 & - & 1 & - & - & 5 \\
Aiari (2) & 6 & 90 & 9 & 37 & 14 & 4 & - & 160 \\
Baixo Içana (3) & 4 & 10 & 125 & 14 & 20 & 1 & - & 174 \\
Alto Içana (4) & 1 & 27 & 14 & 142 & 4 & 5 & 1 & 194 \\
fora (5) & 4 & 9 & 14 & 7 & 6 & 1 & - & 41 \\
Colômbia (6) & - & 1 & 3 & 7 & 1 & - & - & 12 \\
Venezuela (7) & - & 1 & - & - & - & - & - & 1 \\
\hline Total & 16 & 140 & 166 & 207 & 46 & 11 & 1 & 587 \\
\hline
\end{tabular}

casamento fora da microrregião casamento dentro da microrregião

Fonte: Ciarn. 
- Sub-região do Negro Acima

Esta sub-região é tradicionalmente ocupada pelos Baré e Werekena, existindo também comunidades baniwa na foz do rio Içana. A maior parte dos homens e mulheres naturais desta sub-região continua na mesma área após o casamento. Pode-se constatar que os homens naturais desse trecho do rio Negro e do rio Xié estão casados com mulheres naturais das mesmas microrregiões.

Tabela 9 - Sub-região do Negro Acima - casamentos dos residentes por oriçem geográfica dos cônjuges

\begin{tabular}{cccccccc}
\hline & \multicolumn{7}{c}{ Mulheres } \\
\cline { 2 - 8 } Homens & $(1)$ & $(2)$ & $(3)$ & $(4)$ & $(5)$ & $(6)$ & Total \\
\hline Negro (1) & 118 & 1 & 5 & 31 & 2 & 1 & 158 \\
Cucuí (2) & 16 & 13 & - & 6 & 1 & - & 36 \\
Xié (3) & 3 & - & 57 & 15 & 1 & - & 76 \\
fora (4) & 22 & 4 & 11 & 56 & 1 & 1 & 95 \\
Colômbia (5) & - & - & 2 & 5 & - & - & 7 \\
Venezuela (6) & 1 & - & 2 & - & - & - & 3 \\
\hline Total & 160 & 18 & 77 & 113 & 5 & 2 & 375 \\
\hline
\end{tabular}

casamento fora da microrregião

casamento dentro da microrregião

Fonte: Ciarn.

Tanto no rio Xié, quanto nesse trecho do rio Negro, após o casamento, os homens e mulheres permanecem residindo em suas microrregiões de origem em proporções quase iguais, o que é um pouco diferente do que ocorre nas outras sub-regiões.

Cucuí é um pequeno centro urbano localizado no trecho do rio Negro desta sub-região do Negro Acima. Faz fronteira com a Venezuela e Colômbia, e possui uma escola de ensino fundamental, e um pelotão de fronteira do exército. O povoado se originou de uma comunidade baré, população majoritária deste centro urbano ainda atualmente. De todos os homens e mulheres naturais deste centro urbano (36 e 18, respectivamente) todas as mulheres e 35 homens permanecem neste mesmo local. Este é o único caso em que não foi possível observar a tendência da maior permanência dos homens. Dos 35 homens naturais e residentes em Cucuí, 15 deles estão casados com mulheres do Negro, 13 com mulheres de Cucuí mesmo, e seis com mulheres de fora; apenas um homem está casado com uma mulher da Colômbia. 
- Sub-região do Negro Abaixo

Esta sub-região é tradicionalmente ocupada pelos Baré e é onde está localizada a cidade de São Gabriel da Cachoeira, sede do município. Esta sub-região vem recebendo há muitos anos famílias indígenas oriundas de outras sub-regiões, e já em 1992, ano do Ciarn, existiam vários bairros indígenas na cidade. No trecho do rio Negro que vai desde São Gabriel até Santa Isabel existem muitas comunidades ocupadas por famílias tukano. As análises feitas desta sub-região se diferenciam das outras: nos outros casos as pessoas nascidas em sub-regiões distintas daquelas estudadas estão classificadas como originárias de 'fora'. Nesta sub-região as pessoas foram classificadas por sub-região de origem, para dar uma idéia melhor da composição dos adultos por origem geográfica, dado que se trata de uma região de destino de migração. As pessoas classificadas como naturais de 'fora' na Tabela 10 são procedentes de outros municípios, sobretudo de Barcelos.

São 542 casais aí residentes; destes, 292 são homens naturais desta sub-região e 250 naturais de outras áreas, incluindo Colômbia, Venezuela e fora. Das outras quatro sub-regiões estudadas, é de Iauaretê que se origina o maior número de homens aí residentes, seguida pelas sub-regiões do Tiquié/Uaupés, Negro Acima e Içana.

Os homens naturais do trecho do rio Negro residentes nesta sub-região estão casados com mulheres naturais desta mesma microrregião (Tabela 10). Dentre os homens naturais e residentes em São Gabriel da Cachoeira, a maioria está casada com mulheres desta cidade, o que não é o padrão observado nos outros centros urbanos.

Tabela 10 - Sub-região do Negro Abaixo - casamentos dos residentes por origem geográfica dos cônjuges

\begin{tabular}{ccccccccc}
\hline & \multicolumn{8}{c}{ Mulheres } \\
\cline { 2 - 9 } Homens & $(1)$ & $(2)$ & $(3)$ & $(4)$ & $(5)$ & $(6)$ & $(7)$ & Total \\
\hline Sáo Gabriel (1) & 16 & 8 & 6 & - & 4 & 2 & - & 36 \\
Negro (2) & 8 & 165 & 22 & 23 & 24 & 11 & 3 & 256 \\
Iauareté (3) & 2 & 19 & 38 & 3 & 21 & 4 & 3 & 90 \\
Içana (4) & 1 & 9 & 2 & 27 & 1 & - & - & 40 \\
Tiquié/Uaupés (5) & 2 & 12 & 14 & 1 & 32 & 2 & - & 63 \\
Negro Acima (6) & 7 & 4 & 2 & 5 & 5 & 22 & - & 45 \\
Colômbia (7) & - & 1 & - & 1 & 1 & 1 & 1 & 5 \\
Venezuela (8) & - & 1 & - & - & - & - & - & 1 \\
fora (9) & - & 4 & 1 & - & 1 & - & - & 6 \\
\hline Total & 36 & 223 & 85 & 60 & 89 & 42 & 7 & 542 \\
\hline
\end{tabular}

casamento fora da microrregião casamento dentro da microrregião Fonte: Ciarn. 
De todos os homens e mulheres naturais deste trecho do rio Negro (256 e 223 , respectivamente), $76 \%$ dos homens e $80 \%$ das mulheres continuam residindo nesta mesma microrregião. Esta é uma tendência não constatada nos diferentes trechos de rios das outras sub-regiões; entretanto, é a tendência do centro urbano de Cucuí.

É interessante notar também que dos homens naturais das outras subregiões estudadas, os de Iauaretê estão casados com mulheres de lá mesmo ou do Tiquié/Uaupés; os do Içana e do Tiquié/Uaupés estão casados em sua maioria com mulheres das mesmas regiões; e entre os homens do Negro Acima metade está casada com mulheres de lá, e os outros $50 \%$ com mulheres das outras sub-regiões.

As análises feitas por etnia mostram o que já havia sido relatado pelos diferentes antropólogos especialistas no noroeste amazônico, ou seja, que existe de fato uma permanência da regra da exogamia lingüística para os povos tukano, e da endogamia de povo, para os povos aruak e maku. Pode-se observar ainda que os Tukano têm um maior número de casamentos registrados com os povos tariana, desana e tuyuka e que os Tariana têm um maior número de casamentos com os Tukano e Pira-tapuia. Nota-se ainda que os povos majoritários em suas sub-regiões de origem casam-se com um número maior de etnias diferentes, podendo, assim, estabelecer alianças políticas, econômicas e rituais mais amplas.

Do ponto de vista das trocas por origem geográfica dos cônjuges, confirmase nesta análise que as microrregiões de origem se articulam por intermédio dos casamentos, e nos centros urbanos/missionários não se observou a formação dessas unidades de troca matrimonial. Talvez este fato confirme a hipótese formulada por Goldman (1963) de que o princípio da proximidade geográfica envolve também uma preferência por não casar dentro de sua própria comunidade, sendo imprescindível estabelecer alianças com outras unidades geográficas. Apenas na cidade de São Gabriel pudemos verificar um grande número de casamentos ocorridos neste mesmo centro urbano. É relevante notar que as associações indígenas locais da região, geralmente possuem uma referência geográfica, e não étnica. A maior parte dessas associações representa um trecho de rio, e suas diretorias muitas vezes são compostas por um grupo de irmãos e cunhados.

ANEXO I - Relação de povos e respectivas siglas

Povos de línguas tukano:
AR: Arapaso
BA: Bará
BS: Barasiana
CA: Karapanã 
DE: Desana

JU: Yurutí

KO: Kubeo

MK: Makuna

MI: Mirititapuia

PI: Piratapuia

TA: Tariana ${ }^{13}$

TU: Tukano

TY: Tuyuka

UA: Wanana

Povos de línguas aruak:

$\mathrm{BN}$ : Baniwa

BR: Baré

CO: Coripaco

UE: Werekena

Povos de línguas maku:

MA: $\mathrm{Maku}^{14}$

Outros:

d: desconhecida

N: não-índio

\section{Anexo II - Subdivisão dos trechos de rios ou centros missionários das cinco sub-regiões estudadas}

Sub-região de Iauaretê:

- Papuri - margem direita desse rio ou nos igarapés dessa margem;

- Uaupés Acima - margem esquerda do Uaupés acima do povoado de Iauaretê;

- Uaupés - as duas margens desse rio, abaixo do povoado de Iauaretê e até a comunidade de Urubuquara, logo acima da cachoeira de Ipanoré;

- Iauaretê Centro - povoado originado de uma missão salesiana do início do século XX, que hoje em dia conta com 2.800 pessoas. 


\section{Sub-região do Tiquié/Uaupés:}

- Alto Tiquié - desde a fronteira com a Colômbia até as comunidades de São Tomé e Taracuá;

- Baixo Tiquié - desde as comunidades de Cunuri e Tapira Ponta até a foz do Tiquié no Uaupés;

-Uaupés - desde Ipanoré, no médio curso desse rio, logo abaixo da cachoeira do mesmo nome, até a sua foz no rio Negro;

- Taracuá Centro - centro missionário salesiano (como Iauaretê, Assunção do Içana e Pari Cachoeira), formando um povoado em torno de um hospital e uma escola de ensino fundamental;

- Pari Cachoeira Centro - originário também de uma missão salesiana, hoje em dia um povoado que conta com uma escola de ensino fundamental completo; é o segundo maior povoado da região do alto rio Negro, depois de Iauaretê Centro.

Sub-região do Içana:

- Alto Içana - da fronteira com a Colômbia até Tunuí Cachoeira (inclusive);

- Baixo Içana - de Tunuí Cachoeira (exclusive) até a foz deste rio no Negro, incluindo aí as comunidades do rio Cubate;

- Aiari - afluente do Içana, desde sua foz até as cabeceiras, região próxima do trecho de rio Uaupés Acima, localizado na sub-região de Iauaretê;

- Assunção Centro - centro missionário de tamanho semelhante ao de Taracuá.

\section{Sub-região do Negro Acima:}

- Negro - desde a fronteira com a Colômbia e Venezuela (exclusive o povoado de Cucuí) até antes da comunidade de Bauari;

- Xié - inclui as comunidades das margens desse rio, afluente do Negro;

- Cucuí - centro urbano situado na margem do rio Negro, na fronteira com a Colômbia e Venezuela.

\section{Sub-região do Negro Abaixo:}

- Negro - desde Bauari até a comunidade de Uábada, município vizinho de Santa Isabel;

- São Gabriel da Cachoeira - centro urbano sede do município, onde foram recenseadas as famílias indígenas. 
1 Trata-se do que Ribeiro (1995) chama de "área cultural do rio Negro"; excluiu-se, portanto, os Yanomami. Os povos de língua tukano (todos do grupo tukano oriental) são os seguintes: Barasana, Juruti, Kubeo (Cubeo), Arapaso, Wanana (Uanano), Desana, Karapanã, Piratapuia, Tukano, Mirititapuia, Bara, Carapanã e Tuyuka. Os de língua maku são: Hupdë, Dow e Yuhupdë. Os de língua aruak são: Baniwa, Coripaco, Bare, Werekena e Tariana.

2 Não existe informação, por exemplo, sobre a relação entre irmãos chefes de domicílios numa mesma comunidade, o que seria fundamental para uma análise mais acurada das trocas matrimoniais.

3 Neste trabalho, os termos grupo lingüístico, etnia, povo e tribo são utilizados como sinônimos.

4 Os primos paralelos se distinguem dos primos cruzados por serem filhos de irmãos do mesmo sexo dos seus genitores, isto é, a prima paralela de um homem é a filha da irmã de sua mãe ou do irmão de seu pai.

5 A palavra tukano, guando grafada em itálico, indica todas as etnias falantes de línguas pertencentes ao Tukano Oriental.

6 Entende-se por grupos de fogos a unidade social mínima, geralmente composta por famílias nucleares.

7 A exceção para essa regra é o caso das comunidades maku, como já mencionado.

8 Aqui se faz referência ao mito de origem das diferentes etnias da região, quando a cobra grande, ou anaconda, em cada parada que fazia ao subir ou descer os rios 'paria' o primeiro homem do grupo lingüístico, sua mulher e seu cunhado.

9 Incluem-se aqui os Tariana, uma vez que, apesar de serem falantes de uma língua aruak, estão inseridos há muito tempo no sistema de trocas matrimoniais dos tukano.

10 O Ciarn não pesquisou o sib nem a fratria de cada pessoa, apenas a origem (nascimento) de cada cônjuge e o seu pertencimento a uma determinada etnia.

11 É importante lembrar que o censo foi levado a efeito pela Foirn e suas organizações filiadas em 1992.

12 Neste trabalho é utilizada a idéia de nexo regional formulada por Cabalzar (2000) para explorar o que denominei microrregiões de trocas matrimoniais. Estas microrregiões ou trechos de rios, delimitados para efeito destas análises, são maiores geograficamente do que o conceito de nexo regional e não se interseccionam.

13 Os Tariana falam uma língua aruak; porém, hoje em dia, a maioria fala somente o tukano, convivem e se casam com povos de língua tukano, por isso estão assim classificados.

14 Os Maku foram todos identificados pela família lingüística, pois assim os classificaram os recenseadores na maioria dos casos. 


\section{Referências Bibliográficas}

ADAMS, K. Demographic change and marriage choices in one Carib family. South American Indian Studies, 4:5-10, 1994.

ÅRHEM, K. The Makú, the Makuna and the Guiana System: transformation of social structure in northern Lowland South America. Ethnos, 1-2:5-22, 1989.

BUCHILLET, D. Os índios da região do alto rio Negro. História, etnografia e situação das terras. Laudo elaborado para a demarcação das Terras Indígenas da região, posteriormente revisto para o anticontraditório, 1992. (Mimeo.)

CABALZAR, A. Organização Social Tuyuka, 1995. Dissertação de Mestrado, São Paulo, Departamento de Antropologia, Programa de Pós-Graduação em Antropologia Social: Universidade de São Paulo.

CABALZAR, A. Descendência e aliança no espaço tuyuka. A noção de nexo regional no noroeste amazônico. Revista de Antropologia, 43:61-88, 2000.

CHERNELA, J. M. Estrutura social no Uaupés. Anuário Antropológico 1981, pp. 59-70, Fortaleza e Rio de Janeiro: Universidade Federal do Ceará e Tempo Brasileiro, 1983.

COIMBRA Jr., C. E. A. et al. The Xavánte in Transition: Health, Ecology and Bioanthropology in Central Brazil. Ann Arbor: University of Michigan Press, 2002.

GOLDMAN, I. The Cubeo Indians of the Northwest Amazon. Urbana: University of Illinois Press, 1963.

HUGH-JONES, C. From the Milk River: Spatial and Temporal Processes in Northwest Amazonia. Cambridge: Cambridge University Press, 1979.

JACKSON, J. Vaupés marriage practices. In: KENSINGER, K. M. (Org.) Marriage Practices in Lowland South America. Urbana: University of Illinois Press, 1984. p.156-179.

LARAIA, R. Arranjos poliândricos na sociedade suruí. Revista do Museu Paulista, XIV:7175, 1963. (Nova Série)

LASMAR, C. De Volta ao Lago do Leite: a experiência da alteridade em São Gabriel da Cachoeira (alto rio Negro), 2002. Tese de Doutorado, Rio de Janeiro: Programa de Pós-Graduação em Antropologia Social, Universidade Federal do Rio de Janeiro.

PAGLIARO, H. A Revolução Demográfica dos Povos Indígenas: a experiência dos Kaiabi do Parque Indígena do Xingu, Mato Grosso (1970-1999), 2002. Tese de Doutorado, São Paulo: Faculdade de Saúde Pública, Universidade de São Paulo.

POZZOBON, J. O mínimo demográfico de um sistema de metades exogâmicas (uma simulação.em computador). Revista Brasileira de Estudos de População, 11:139154, 1994.

RIBEIRO, B. G. Os Índios das Águas Pretas. São Paulo: Companhia das Letras/Edusp, 1995.

SILVERWOOD-COPE, P. L. Os Makú: povo caçador do noroeste amazônico. Brasília: UnB, 1990.

WRIGHT, R. The History and Religion of the Baniwa Peoples of the Upper Rio Negro Valley, 1981. Tese de Doutorado, Ann Arbor: University Microfilms. 



\section{Demografia, Epidemias e Organização Social: os Xavánte de Pimentel Barbosa (Etéñitépa), Mato Grosso ${ }^{1}$}

\section{Introdução}

No livro Os Índios e a Civilização, Darcy Ribeiro (1977) escreveu um longo capítulo sobre as epidemias e suas conseqüências sobre os povos indígenas. Nele, cujo título é 'Convívio e contaminação', o antropólogo afirma que "bacilos e vírus" foram importantes "armas de conquista", tendo contribuído sobremaneira para o processo de subjugação das sociedades indígenas em face do expansionismo ocidental. Inovador para sua época (o texto foi originalmente escrito na década de 1950), a descrição de Ribeiro sobre "os efeitos dissociativos da depopulação e do debilitamento por eles provocados" (1977:273) beira o senso comum nos dias atuais, algo amplamente conhecido em virtude de sua recorrência histórica.

Sabemos que, em seus determinantes e conseqüências, o quadro esboçado por Ribeiro não é uma particularidade do Brasil. Muito pelo contrário. Se, por um lado, os povos indígenas das Américas, do Ártico ao extremo sul da América do Sul (somente no Brasil são atualmente em torno de 220 povos, falantes de cerca de 180 línguas diferentes), apresentam grande diversidade histórica, social e cultural, por outro, compartilham de uma devastadora experiência: a ocorrência de severas crises demográficas, que resultaram em acentuadas reduções populacionais e extinção de inúmeras sociedades a partir da chegada dos colonizadores. Embora antropólogos, demógrafos e historiadores estejam longe de um consenso acerca da intensidade da depopulação ocorrida desde o século XV (alguns chegam a afirmar que foi da ordem de $80 \%$ ou mais), não há dúvidas de que as principais causas da elevada mortalidade foram epidemias de doenças infecciosas e parasitárias (Crosby, 1972; Dobyns, 1983; Hemming, 1987; Gomes, 1988; Denevan, 1992; Cook, 1998).

Apesar de sua recorrência e da potencial ameaça à sobrevivência biológica e cultural dos povos indígenas, as dinâmicas dessas crises demográficas são pouco conhecidas. Um aspecto especialmente importante é compreender como as estruturas sociais das sociedades indígenas podem ter sido afetadas pelas epidemias e pela conseqüente depopulação. Esse ponto recebeu atenção de alguns 
antropólogos, como o próprio Ribeiro, que apresenta em seu livro uma série de exemplos das "profundas mudanças na distribuição e nas inter-relações dos vários grupos locais, no sistema associativo, na forma de família, de casamento, de todas as instituições tribais". Algo bem menos explorado na literatura etnológica é a recíproca, qual seja, como as características sociais de uma dada sociedade podem influenciar o curso da crise e a eventual recuperação demográfica subseqüente. A parca literatura acerca do modo como a estrutura social das sociedades indígenas pode ter sido afetada pelas epidemias e pela conseqüente depopulação (e viceversa) é particularmente surpreendente diante da longa tradição de pesquisas em etnologia indígena no Brasil.

O estudo de caso sobre os Xavánte que se aborda neste trabalho tem dois objetivos: primeiro, por meio da análise de dados de fecundidade e de mortalidade, documenta-se a crise demográfica que atingiu o grupo no período pós-contato, a partir da década de 1940; segundo, busca-se argumentar como certos aspectos da organização social Xavánte foram cruciais, afetando não apenas o modo como a crise evoluiu, como também a recuperação demográfica que se seguiu.

\section{Os Xavánte}

Os Xavánte, que no início da década de 1990, quando esta investigação foi realizada, totalizavam cerca de 8 mil indivíduos, vivem em seis Terras Indígenas (T.I.) no leste do estado de Mato Grosso (há uma sétima em processo de desocupação e demarcação, Marãiwasede). A pesquisa foi realizada na T.I. Pimentel Barbosa, onde está localizada a comunidade de Etéñitépa.

No início do século XVIII, quando ocorreram os primeiros contatos com não-índios, os Xavánte localizavam-se no que atualmente é o estado de Goiás, a leste da região que ocupam no presente. Cartas dos governadores coloniais a Lisboa descreviam 'problemas com os índios', demonstrando que os Xavánte e outros grupos resistiam à invasão de suas terras, atacando minas e investindo contra o gado e as plantações dos colonos. O governo da colônia conseguiu 'pacificar' e fixar uma série de grupos, incluindo os Xavánte, em grandes assentamentos de missões. As doenças e a fome reduziram drasticamente seus números. Ao final do século XVIII, a maior parte das missões encontrava-se abandonada. No século e meio segúinte, os Xavánte continuaram a resistir à expansão da colonização, movendose na direção oeste. A autonomia Xavánte foi irreversivelmente quebrada na década de 1940, quando o governo empreendeu esforços para 'desenvolver' as regiões centrais do Brasil.

Em 1946, um subgrupo Xavánte liderado por um chefe chamado Apowe tornou-se o primeiro a estabelecer contato permanente com os agentes do SPI (Serviço de Proteção aos Índios). Membros deste subgrupo e seus descendentes 
vivem atualmente na T.I. Pimentel Barbosa. No início dos anos 90, encontravamse assentados em uma aldeia principal, denominada Etéñitépa, e em duas menores (Caçula e Tanguro).

Durante os dez primeiros anos após o contato permanente (1946-1956), os Xavánte de Etéñitépa permaneceram relativamente isolados e independentes. Continuavam a praticar uma estratégia de subsistência baseada na caça e na coleta, com a agricultura ocupando um plano secundário. Durante os quinze anos seguintes, de 1957 a 1971, sofreram os devastadores efeitos do contato, com muitas epidemias e mudanças nas estratégias de subsistência. Aumentou então sua dependência da agricultura. As décadas de 1970 e 1980 foram períodos de recuperação demográfica. Foi também um tempo de intensos esforços para garantirem seus direitos às terras. No final da década de 70 e início da de 80 , os Xavánte participaram de um projeto governamental de rizicultura mecanizada voltado para o mercado regional. O projeto fracassou e a produção intensiva do arroz foi logo abandonada. Os limites da reserva foram finalmente demarcados e garantidos durante a década de 80 . Como um todo, os dados indicam um período de crise pós-contato durante a década de 60 , seguidos por uma recuperação demográfica. A longo prazo, tem-se observado uma tendência em direção à intensificação das relações com o mercado regional. Para maiores informações acerca da história Xavánte, ver particularmente Coimbra Jr. et al. (2002), Garfield (2001), Graham (1995), Lopes da Silva (1992) e Santos et al. (1997).

\section{Fontes e coleta de dados}

Os dados demográficos analisados neste trabalho derivam de diversos recenseamentos e de histórias reprodutivas de mulheres Xavánte, registrados por Flowers ao longo de 14 meses de pesquisa em Etéñitépa, entre 1976/1977. Na década de 90, quando esta equipe realizou trabalho de campo em Etéñitépa em diversas ocasiões, dados demográficos foram novamente coletados.

Informações disponibilizadas por pesquisadores que trabalharam entre os Xavánte em períodos anteriores foram muito úteis para as análises. As genealogias registradas por Maybury-Lewis (1967:317-342), publicadas em sua monografia Akwe-Shavante Society, forneceram os nomes dos adultos e as relações entre aqueles que viviam na comunidade à época de sua pesquisa, entre 1958 e 1962. O geneticista Jámes V. Neel gentilmente forneceu-nos cópias de suas anotações de campo, contendo os nomes e as idades estimadas dos indivíduos examinados durante seu trabalho de campo em 1962 (Neel et al., 1964).

Todos aqueles que coletaram dados demográficos em sociedades sem escrita sabem que um dos objetivos mais difíceis de se alcançar, embora essencial, é estabelecer, com a maior precisão possível, as idades dos indivíduos (ver Black et al., 1978; Howell, 1979; Chagnon, 1983; Early G Peters, 1990, 2000; Early G Headland, 
1998; Hill G Hurtado, 1996, entre outros). Em 1977, um dos instrumentos utilizados por Flowers para estimar as idades foi um calendário de eventos, que se mostrou especialmente útil para se perguntar aos pais quanto às datas de nascimento de seus filhos. Exemplos destes eventos são quando os Xavánte tiveram seu primeiro contato pacífico com funcionários do governo (em 1946); quando o antropólogo Maybury-Lewis e sua família viveram entre eles (em 1958); quando o grupo mudouse para a sua atual localização, Etéñitépa (em 1972), e assim por diante. Quando a data de nascimento aproximada podia ser determinada para uma criança, as idades relativas de seus irmãos e irmãs podiam ser estimadas.

A sociedade Xavánte apresenta algumas características que facilitaram nossas investigações demográficas. Diferentemente de outros grupos das terras baixas sul-americanas, como os Suruí (Coimbra Jr., 1989), os Xavánte não possuem proibições quanto a falar a respeito dos mortos. Se isso houvesse ocorrido, recuperar dados demográficos por meio de entrevistas teria sido ainda mais difícil. A estimativa das idades foi ainda facilitada pela existência de um sistema de classes de idade (ver adiante). Os próprios Xavánte usam este sistema, afirmando, por exemplo, que este ou aquele evento ocorreram quando meninos filiados a uma classe de idade determinada ocupavam a casa destinada aos rapazes solteiros (hö).

\section{O ciclo de vida Xavánte}

A organização social dos Xavánte é marcadamente complexa. A relação entre os sistemas de categorias de idade e de classes de idade é exemplar neste sentido. Enquanto as categorias de idade referem-se aos estágios de vida para homens e mulheres (crianças pequenas, adolescentes, jovens adultos e adultos maduros), o sistema de classes de idade é composto por oito classes nomeadas que se alternam em um ciclo de 40-50 anos.

Os meninos entre oito e treze anos de idade tornam-se wapté. Deixam então suas casas e passam a viver em grupo no hö, ou 'casa dos solteiros'. especialmente construída para este fim em uma das extremidades da aldeia. $O$ menino passa a integrar uma classe de idade quando vai residir no hö, onde permanecerá por aproximadamente cinco anos, quando então sua classe será iniciada e poderá casar-se. Os meninos que vivem no hö não são isolados da vida da aldeia. Podem visitar suas casas e trabalhar com seus pais nas roças familiares. O sistema de classes de idade também se aplica às mulheres. Há, contudo, importantes diferenças. As jovens da mesma classe de idade dos wapté não são separadas de suas famílias.

Os sistemas de clãs e de linhagens são duas outras dimensões fundamentais da organização social Xavánte. Os Xavánte possuem um sistema de 
clãs patrilineares (i.e., a criança pertencerá ao clã de seu pai). Três clãs são reconhecidos pelos Xavánte: Poridza'õno, Öwawe e Topdató.

Ainda que o clã seja a unidade fundamental da organização social Xavánte, tendendo a permanecer estável ao longo do tempo, o sistema político opera principalmente através das linhagens. Cada um dos clãs é constituído de várias linhagens: Poridza'õno (Wamãri e Tebe); Öwawe (Uhö e Dzutsi) e Topdató (Aiuté'mañãri e Wahi) (Figura 1). As relações entre as linhagens tendem a ser conflitantes, uma vez que "... estão em eterna disputa por poder e prestígio..." (Maybury-Lewis, 1967:190).

Os Xavánte consideram incestuoso o casamento entre membros dos clãs Öwawe e Topdató. Os casamentos preferenciais são aqueles entre os membros do clã Poridza'õno e os dois outros. Assim, pode-se afirmar que os Xavánte possuem "um sistema de metades exogâmicas, com dois clãs em uma metade e um na outra" (Maybury-Lewis, 1967:75). Flowers observou, em 1976/1977, que essas regras encontravam-se operantes em Etéñitépa.

Figura 1 - Composição dos clãs (em maiúsculas) e linhagens Xavánte, com as setas indicando o padrão de exogamia prescrita

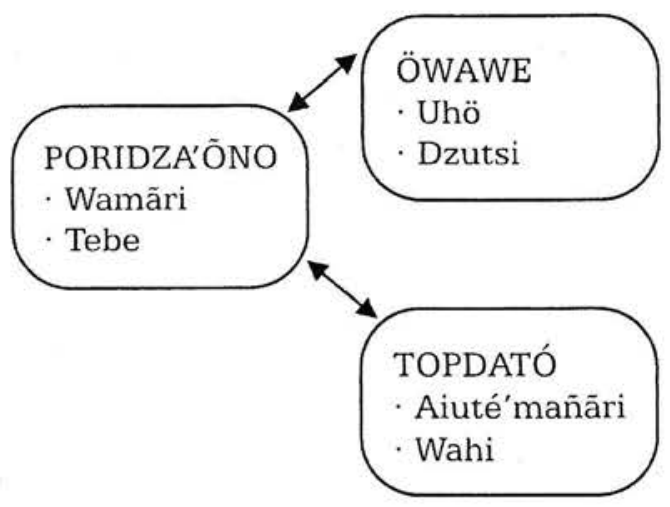

Os Xavánte praticam a poliginia. Entre eles a poliginia é largamente sororal, isto é, se um homem jovem busca uma esposa em um domicílio onde há irmãs, ele pode se casar inicialmente com a mais velha, e a seguir com a irmã ou irmãs mais jovens, à medida que elas atingem a idade apropriada. Alguns homens, após anos de casamento ou após a morte da primeira esposa, podem casar-se com uma mulher muito mais jovem. A poliginia leva a uma situação de constante escassez de mulheres para os homens jovens. Os homens Xavánte não podem casar-se até que sua classe de idade seja iniciada, quando a maior parte deles encontra-se entre os 15 e 18 anos. É ao final da iniciação que cada rapaz irá desposar uma jovem, filiada ao clã apropriado. No entanto, pode se passar um longo tempo antes 
da consumação do casamento, já que os rapazes freqüentemente desposam meninas muito jovens e vários anos são necessários para que elas cheguem à puberdade.

\section{Demografia e mudanças}

Aqui, a análise da demografia dos Xavánte de Etéñitépa será baseada em três períodos: até 1956, de 1957 a 1971 e de 1972 a 1990. Escolheu-se o ano de 1957 como ponto de corte porque a partir desse momento houve importantes mudanças nos padrões de interação entre os Xavánte e os não-índios. MayburyLewis (1967:27-29) demonstra que a segunda metade da década de 50 constituiu um momento decisivo para o grupo. Referiu-se aos Xavánte, nesse período, como "o mais poderoso, o mais numeroso e o menos aculturado" subgrupo Xavánte (1967:27). Quando o antropólogo retornou em 1962, percebeu que grandes mudanças haviam tido lugar, como a diminuição da população graças às epidemias e às disputas políticas. Assim, as evidências etnográficas sugerem que o período que vai de 1957 a 1971 foi sobremodo estressante para os Xavánte. O ano de 1972 foi escolhido como outro ponto de corte, uma vez que foi então que o grupo transferiu a aldeia para sua atual localização (Etéñitépa). As epidemias, que atingiram os Xavánte na década anterior, haviam então retrocedido. Durante as décadas de 70 e 80, ocorreram grandes mudanças nas estratégias de subsistência, o que inclui um estilo de vida mais sedentário e mesmo o cultivo de produtos para o mercado regional. $\mathrm{O}$ contato permanente com o mundo exterior tornou-se uma rotina.

\section{Tamanho populacional}

A comparação de dados sobre tamanho da população em Pimentel Barbosa coletados em 1990 com outros obtidos em décadas anteriores mostra tendências bastante claras. A Figura 2 indica os tamanhos populacionais em cinco momentos entre 1958 e 1990. Nas décadas de 1950 e 1960, o tamanho da população manteve-se estável, notando-se um ligeiro decréscimo populacional. A partir de 1969, nota-se um franco crescimento: a população aumentou de aproximadamente 200 para quase 450 pessoas em 1990. Aconteceu, também, alteração na composição etária. Em 1962, Neel et al. (1964:92) observaram que $39 \%$ da população eram compostas de menores de 15 anos. Em 1990, a percentagem havia crescido para $54 \%$, situação que resultou de uma queda da mortalidade e de um aumento da fecundidade, como se verá adiante. 
Figura 2 - Tamanho da população dos Xavánte de Pimentel Barbosa em diferentes períodos

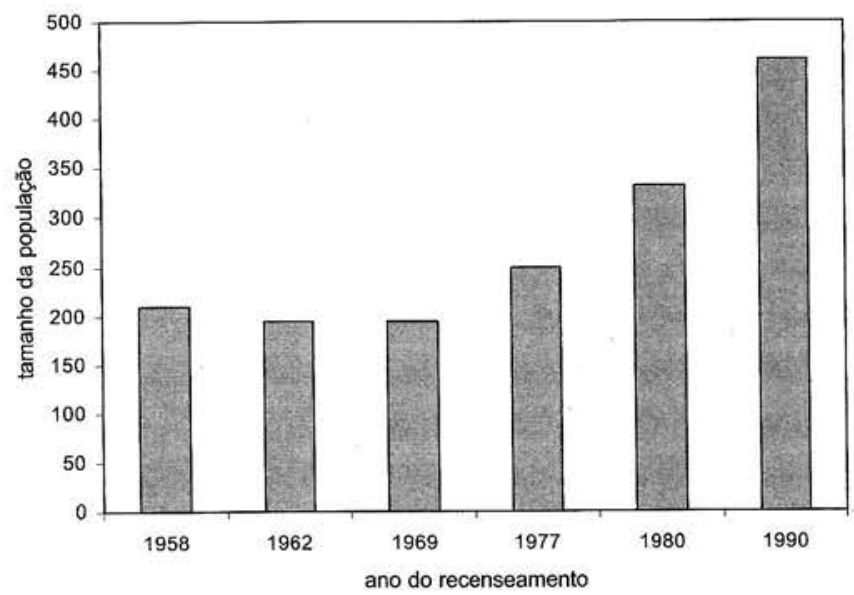

Fonte: Coimbra Jr. et al., 2002.

\section{Tendências da mortalidade em crianças}

Durante as entrevistas com as mulheres Xavánte em 1976/1977 e 1990, perguntou-se não somente quantos filhos elas haviam tido, mas também quais crianças haviam falecido e quando isso ocorrera. Com base nesses dados, caracterizouse a experiência de mortalidade e sobrevivência das crianças menores de dez anos para os três períodos. Os dados apresentados combinam meninos e meninas. Quando foram conduzidas as análises para cada um dos sexos nos três períodos, não se verificou um padrão consistente de maior mortalidade segundo sexo.

Os resultados demonstram claramente que a sobrevivência até os dez anos era muito menor de 1957 a 1971 (43\%) que nos demais períodos. De 1927 a 1956, aproximadamente $73 \%$ dos nascidos chegavam aos dez anos de idade, e de 1972 a 1990 , cerca de $83 \%$ (Tabela 1).

As crianças menores de um ano foram as que apresentaram a maior taxa de mortalidade nos três períodos. Quando as taxas de sobrevivência foram as mais baixas (de 1957 a 1971), mais de $20 \%$ das crianças não chegavam a completar um ano de idade (Tabela 1). Nos demais períodos, as taxas observadas foram também maiores entre os menores de um ano.

As epidemias de doenças infecciosas constituíram provavelmente a principal causa do aumento das taxas de mortalidade entre 1957 e 1971. Infelizmente, são escassas as informações acerca da etiologia das mortes que ocorreram nesse período. Além dos relatos de Neel et al. (1964) e de Maybury- 
Lewis (1967), que se referem ao período anterior a 1963, não foi possível obter informações adicionais sobre a situação da comunidade durante a década de 60 .

Tabela 1 - Mortalidade e sobrevivência de crianças Xavánte 0-10 anos, sexos combinados, em diferentes períodos

\begin{tabular}{|c|c|c|c|c|c|c|c|c|c|c|c|c|}
\hline \multirow[b]{2}{*}{$\begin{array}{l}\text { Idade } \\
\text { (anos) }\end{array}$} & \multicolumn{4}{|c|}{$1927-1956$} & \multicolumn{4}{|c|}{$1957-1971$} & \multicolumn{4}{|c|}{$1972-1990$} \\
\hline & n. de crianças & n. de óbitos & $\begin{array}{c}\text { Probabalidade } \\
\text { de óbito } \\
\text { (nqx) }\end{array}$ & $\begin{array}{l}\text { Sobreviventes } \\
\text { (Ix) }\end{array}$ & n. de crianças & n. de óbitos & $\begin{array}{l}\text { Probabililiade } \\
\text { de óbito } \\
\text { (nq̣x) }\end{array}$ & $\begin{array}{l}\text { Sobreviventes } \\
\text { (lx })\end{array}$ & n. de crianças & n. de óbitos & $\begin{array}{l}\text { Probabilidade } \\
\text { de óbito } \\
\text { (nqx) }\end{array}$ & $\begin{array}{c}\text { Sobreviventes } \\
\text { (1x) }\end{array}$ \\
\hline 0 & 56 & $\infty 6$ & 0,089 & 1000 & 128 & 26 & 0,203 & 1000 & 294 & 30 & 0.102 & 1000 \\
\hline 1 & 47 & 03 & 0.043 & 911 & 94 & 08 & 0,085 & 797 & 245 & 10 & 0.041 & 898 \\
\hline 2 & 40 & $\infty 2$ & 0.075 & 872 & 71 & 07 & 0,099 & 729 & 219 & 00 & 0.000 & 861 \\
\hline 3 & 36 & 01 & 0,028 & 807 & 57 & 04 & 0.070 & 657 & 199 & 01 & 0,005 & 861 \\
\hline 4 & 32 & 01 & 0,031 & 784 & 46 & 04 & 0.087 & 611 & 188 & 01 & 0,005 & 857 \\
\hline 5 & 30 & 01 & 0,033 & 760 & 37 & 04 & 0,108 & 558 & 170 & 01 & 0,006 & 852 \\
\hline 6 & 27 & 00 & 0,000 & 734 & 30 & 02 & 0,067 & 498 & 158 & 01 & 0.006 & 847 \\
\hline 7 & 26 & 00 & 0.000 & 734 & 23 & 00 & 0,000 & 464 & 134 & 01 & 0,007 & 842 \\
\hline 8 & 22 & 00 & 0,000 & 734 & 19 & 00 & 0,000 & 464 & 125 & 01 & 0,008 & 836 \\
\hline 9 & 21 & 00 & 0.000 & 734 & 14 & 01 & 0.071 & 464 & 106 & 00 & 0.000 & 829 \\
\hline 10 & & & & 734 & & & & 431 & & & & 829 \\
\hline
\end{tabular}

As epidemias de doenças infecciosas freqüentemente precedem ou se seguem imediatamente ao estabelecimento de contato permanente (Ribeiro, 1956; Early G Peters, 1990; Santos G Coimbra Jr., 1998, entre outros). Os Xavánte de Etéñitépa foram o primeiro subgrupo a estabelecer contato pacífico com agentes governamentais, em 1946. Maybury-Lewis (1967:275-276) menciona que, já em 1957, quando caçadores Xavánte seguiram em direção ao rio Araguaia, contraíram gripe em um acampamento de índios Karajá, que mantinham contato freqüente com não-índios. Isto está de acordo com nossos dados demográficos, que sugerem que os Xavánte começaram a experimentar uma elevada mortalidade a partir da segunda década de contato (de 1956 a 1971), e não nos anos que se seguiram imediatamente ao contato. Uma possível razão pela qual a mortalidade veio a aumentar apenas algum tempo após o contato pode ser o fato de que somente em 1953 os Xavánte estabeleceram-se em uma aldeia próxima ao Posto Indígena, construído em um local denominado São Domingos (Maybury-Lewis, 1967:27; Graham, 1995:34). Até então, mesmo que os Xavánte fossem regularmente até o Posto, ainda eram relativamente independentes. A partir do final da década, ficaram muito mais assíduos os contatos com não-índios, fato que pode haver facilitado a introdução de doenças contagiosas. Sob tais condições, é provável que tenham existido colapsos na produção de alimentos, afetando de modo especial as crianças.

No período mais recente (de 1972 a 1990), os níveis de mortalidade entre crianças foram muito mais baixos que aqueles observados entre $1957 \mathrm{e}$ 1971 (Tabela 1). O local em que se encontra atualmente sua aldeia, para onde se 
deslocaram em 1972, é o mesmo que haviam ocupado na década de 40 e no início da década seguinte. Os Xavánte afirmam que retornaram para Etéñitépa porque o consideram um lugar 'saudável' e onde a terra é boa para a agricultura, o que implica que pode haver melhorado o estado nutricional do grupo. Nas décadas de 70 e 80 , embora não regularmente, os Xavánte também recebiam as vacinas fornecidas pelo Ministério da Saúde (BCG, antipólio, anti-sarampo e tríplice), o que pode haver exercido algum efeito sobre a mortalidade.

\section{Tendências da fecundidade}

A Tabela 2 apresenta as taxas específicas de fecundidade (TEF) e as taxas de fecundidade total (TFT) para as mulheres Xavánte, segundo os três períodos.

Para 1972-1990, quando é maior a amostra, observa-se que a fecundidade eleva-se cedo, aos 10-14 anos, atingindo o maior valor aos 20-24 anos, com declínio posterior. Por mais que as mulheres Xavánte comecem a ter filhos já no início da segunda década de vida (correntemente em torno dos 13-14 anos), a TEF da faixa etária de 10-14 anos é muito baixa. As gestações também parecem cessar relativamente cedo, já que a fecundidade das mulheres com idade entre 40-44 anos é próxima de zero.

Tabela 2 - Taxas específicas de fecundidade (TEF) e taxas de fecundidade total (TFT) para mulheres Xavánte, entre 10-44 anos, em diferentes períodos

\begin{tabular}{cccc}
\hline Idade (anos) & $1942-1956$ & $1957-1971$ & $1972-1990$ \\
\hline $10-14$ & 0,056 & 0,068 & 0,050 \\
$15-19$ & 0,339 & 0,359 & 0,356 \\
$20-24$ & 0,263 & 0,240 & 0,412 \\
$25-29$ & 0,300 & 0,232 & 0,323 \\
$30-34$ & 0,438 & 0,143 & 0,246 \\
$35-39$ & 0,100 & 0,135 & 0,183 \\
$40-44$ & 0,125 & 0,000 & 0,000 \\
\hline TFT & 8,01 & 5,88 & 7,86 \\
\hline
\end{tabular}

Os,resultados evidenciam que a fecundidade Xavánte alcançou seu nível mais baixo entre 1957 e 1971 (TFT=5,88). Logo, o final da década de 50 e a década seguinte foram não apenas um período de elevada mortalidade, mas também de queda da fecundidade. Um período marcado pela ruptura social, o que possivelmente resultou em um aumento da instabilidade dos casamentos e também em viuvez precoce para algumas mulheres. Pelas histórias reprodutivas, observa-se 
que onze mulheres, embora com idades próximas de vinte anos, separaram-se de seus esposos ou tornaram-se viúvas na década de 60, havendo um período sem nascimentos até que se casassem novamente. Apesar de os Xavánte serem poligínicos, algumas mulheres podem permanecer sozinhas após a viuvez ou a separação. Ainda que nesta situação possam ter mais um ou dois filhos, é de se esperar que sua fecundidade seja mais baixa que a de mulheres que se encontram em uniões estáveis durante seu período reprodutivo. Em 1976-1977, quando Flowers permaneceu em Etéñitépa, todas as mulheres na faixa dos vinte anos estavam casadas.

A fecundidade das mulheres Xavánte entre 1957 e 1972 (TFT=5,88) foi cerca de $25 \%$ mais baixa, quando comparada aos dois outros períodos. Algumas mulheres afirmaram que, vendo tantas de suas crianças morrerem, incluindo algumas que já não eram mais tão pequenas, "perderam a vontade de ter filhos". Entre os Bororo, outro grupo do Brasil Central, uma mortalidade infantil muito elevada e a redução dos nascimentos redundaram em um declínio acentuado da população; as mulheres constantemente declaravam seu desejo de não ter mais filhos, justificandose com a frase "Eu não quero ver a criança morrer!" (Crocker, 1985:47).

As mulheres Xavánte, contudo, apesar da gravidade da crise que o grupo enfrentava, ainda davam à luz em média a seis crianças. Uma razão para isto pode ter sido uma crescente interação mortalidade-fecundidade durante o período. Em uma revisão sobre a fecundidade nas chamadas 'populações antropológicas', Wood (1990:233-234) afirma que uma das questões mais significativas a serem ainda abordadas na literatura diz respeito às interações entre fecundidade e mortalidade. Segundo esse autor, existem crescentes evidências de que um importante fator de regulação dos níveis de fecundidade em sociedades pré-industriais não é a reprodução em si, mas a mortalidade. O que nos interessa do argumento de Wood é a interação entre a mortalidade infantil e a fecundidade, a que ele se refere como "compensação reprodutiva". Afirma: "quando um bebê morre, a lactação é interrompida e a mãe volta a ovular mais cedo do que ocorreria normalmente" (Wood, 1990:233). Assim, paradoxalmente, em uma situação de elevada mortalidade infantil, a TFT de um determinado grupo de mulheres pode até mesmo aumentar em função de uma redução dos intervalos interpartais. Esta, por sua vez, está associada à interrupção antecipada da lactação e ao conseqüente retorno da ovulação.

Os dados coletados não possibilitam afirmações conclusivas com relação à influência da mortalidade infantil na fecundidade Xavánte; porém, o período entre 1957 e 1971 foi por certo uma época em que este tipo de interação pode haver ocorrido mais corriqueiramente. As probabilidades de óbito nos dois primeiros anos de vida, de 1957 a 1971 (0,203), foram pelo menos duas vezes maior que nos dois outros períodos $(0,089$ e 0,102$)$ (Tabela 1$)$. Isto é, proporcionalmente, as mães Xavánte estavam então perdendo mais crianças que ainda eram amamentadas. 
Parece razoável argumentar que, com a morte de um crescente número de bebês, e com a diminuição do período em que permaneciam amamentando, as mulheres Xavánte apresentavam, naquela época, uma probabilidade maior de engravidar. Durante aqueles anos, as mulheres Xavánte podem ter tido mais filhos, pois com a morte precoce de seus bebês ocorria uma redução dos períodos de infertilidade em virtude da lactação.

Entre 1974 e 1976, o responsável pelo posto indígena que vivia em Etéñitépa registrou as datas dos nascimentos e das mortes. Flowers fez o mesmo durante sua estada na aldeia em 1976-1977. Esses dados, ainda que de fontes diversas, mostram uma associação entre a ocorrência de óbitos infantis e a duração dos intervalos entre os nascimentos. Durante 33 meses de cuidadosos registros, 42 das 65 mulheres com idades entre 15 e 44 anos deram à luz pelo menos uma vez (contando-se apenas os nascidos vivos). Durante este período, catorze mulheres tiveram dois filhos, e apenas uma mulher pariu três. O intervalo interpartal médio foi igual a 20,9 meses entre as mulheres cujos bebês viveram pelo menos até a idade de um ano, e de 16,6 meses entre aquelas cujos bebês haviam morrido antes disso.

Portanto, o declínio da fecundidade nas mulheres não revela na mesma magnitude, se comparada à mortalidade, a dimensão da crise enfrentada pelos Xavánte de Etéñitépa no período pós-contato, talvez em função dos efeitos da compensação reprodutiva.

\section{Epidemias, demografia e ordem social}

Nem todas as mortes ocorridas durante as epidemias pós-contato estão diretamente ligadas a doenças. Quando uma enfermidade estranha e debilitante atinge uma comunidade, a população pode ficar assustada e desorientada, e os laços que normalmente unem indivíduos aparentados podem entrar em colapso. As mulheres que adoecem podem não conseguir alimentar e cuidar de seus filhos (Neel, 1982). O estado nutricional do grupo pode sofrer um impacto adicional, caso a doença impeça os homens de saírem para caçar ou obste as mulheres da coleta de alimentos silvestres e da ida às roças (McGrath, 1991).

À proporção que o aumento da mortalidade ocasiona acusações de feitiçaria e mortes por vingança, uma importante causa indireta de morte entre adultos pode ser a punição de 'bodes expiatórios' (Ross, 1984; Early G Peters, 1990:80; Ferguson, 1990). Em algumas sociedades amazônicas, 'causas naturais' (como doenças) nunca são aceitas como motivos para as mortes (Wagley, 1977:171-172; Seeger, 1981:219-220; Crocker, 1985:36-37). Outras distinguem de diversas maneiras as mortes ocorridas graças às 'causas naturais' daquelas cuja origem 
encontra-se no mundo espiritual ou em feitiços enviados por indivíduos 'maléficos' (ver Buchillet, 1992:216; Crocker G Crocker, 1994:170; Langdon, 1992b:50).

Fundamentando-se em suas observações etnográficas sobre os Xavánte nas décadas de 50 e 60, Maybury-Lewis registrou:

Eles possuem alguma compreensão do contágio e estão conscientes, por exemplo, de que quando entram em contato com um brasileiro que tem tosse, estão sujeitos a contraí-la. E, caso adoeçam, não acreditarão que foram enfeitiçados, a menos que tenham uma boa razão para isso. (1967:274)

Mas o intenso faccionalismo que sempre ameaça a sociedade Xavánte foi exacerbado pelo número não usual de mortes, freqüentemente de homens proeminentes, como veremos.

Quase todas as sociedades amazônicas possuem especialistas espirituais, indivíduos que afirmam poder comunicar-se com os espíritos e influenciar o destino humano curando doenças ou, ao contrário, fazendo o mal (Langdon, 1992a:3-5). Estes especialistas, quase sempre referidos na literatura como xamãs, normalmente não são líderes de facções ou do grupo; em lugar disso, seu poder vem do modo como podem usar seu conhecimento espiritual para o bem ou para o mal. Um mesmo indivíduo que cura como um xamã pode ser suspeito de feitiçaria quando aumenta o número de mortes inexplicadas, chegando eventualmente a ser executado (Wagley, 1977:186-189; Seeger, 1981:86-88, 174; Crocker G Crocker, 1994:112-113). A concentração das suspeitas sobre um indivíduo que acreditam possuir poderes xamãnicos e sua eventual eliminação da sociedade pode, assim, limitar a agitação social que caracteriza tais momentos.

Os Xavánte não vêem a feitiçaria como um atributo de certos indivíduos que possuem tal poder.

Eles acreditam que um Xavánte só pode infligir doença ou morte a outro através do poder de certos rituais que envolvem a manipulação de substâncias ou implementos mágicos. Estas substâncias são pós, que podem ser usados tanto ofensiva como defensivamente. (Maybury-Lewis, 1967:276)

Somente os homens são suspeitos de praticá-la. Quando um homem proeminente adoece ou morre, as suspeitas recaem sobre aqueles que possivelmente teriam mais a ganhar com sua morte. Um evento desta natureza pode desencadear uma disputa em que os homens da facção mais fraca são mortos ou expulsos da aldeia. Como Maybury-Lewis (1967:188-189) assinala, um caso de feitiçaria é uma questão política, já que "todos as questões Xavánte constituem essencialmente questões entre grupos, e não disputas entre indivíduos". Em lugar de se concentrar sobre um único indivíduo, a culpa recai sobre toda a facção ou linhagem. 
Para Maybury-Lewis, nos anos que se seguiram ao contato, ao final da década de 40, o líder Apowe e sua família mantiveram sua influência, por intermédio da distribuição de 'presentes' dados pelos agentes do SPI e também pelo antropólogo (Maybury-Lewis, 1967:28, 171). A introdução de bens manufaturados afetou a comunidade, acirrando a disputa entre as linhagens, a ponto de membros da linhagem Wamâri mobilizarem-se para eliminar outras facções, de modo a assegurarem o controle sobre a distribuição de bens de consumo.

Uma epidemia de gripe que teve lugar em meados de 1960 (MayburyLewis, 1967:176) aparentemente desencadeou uma série de acusações de feitiçaria que, unida à própria doença, reduziu ainda mais a população. Os detalhes do que, de verdade, aconteceu são difíceis de esclarecer.

Alguns membros da linhagem Wamări morreram em uma epidemia de gripe. A facção responsabilizou o clã Topdató e assassinou alguns de seus integrantes... Eu nunca pude determinar quantos Topdató foram mortos, já que os inimigos dos Wamãri veementemente atribuíam todas as mortes ocorridas desde a minha última visita à ferocidade da facção dominante. Os Wamări asseguraram-me, por outro lado, que nenhum Topdató fora morto por eles. Insistiam em que os membros deste clã haviam sofrido ainda mais intensamente os efeitos da epidemia do que os Wamãri. Parece certo, entretanto, que alguns Topdató foram de fato assassinados, embora alguns possam haver morrido de gripe. (Maybury-Lewis, 1967:176)

No início da década de 60 já começava a ficar nítido que as disputas em São Domingos (o local onde os Xavánte viveram até 1962, antes de se mudarem para Etéñitépa) estavam produzindo efeitos visíveis sobre a composição social do grupo:

À época de minha segunda visita [em 1962]... Os Wamãri ainda estavam firmemente estabelecidos como a linhagem dominante, pois havia poucos que pudessem se opor a eles. As únicas linhagens ainda representadas na aldeia eram, respectivamente, os Uhö e os Dzutsi, ambas consideravelmente incompletas... São Domingos era uma das mais homogêneas aldeias que eu havia visitado, em termos de faç̧ōes. (1967:177)

• $\quad$ Crise demográfica e organização social

$\mathrm{Na}$ parte final deste texto, serão exploradas algumas relações entre disputas políticas, violência e mortes por causa das epidemias, e serão investigados seus impactos sobre aspectos específicos da demografia e da dinâmica social Xavánte. Ver-se-á que, a longo prazo, a quase completa eliminação de certos clãs e linhagens levou a desequilíbrios sociais que vieram a afetar os arranjos de casamentos. 
Em 1976/1977, Flowers coletou dados genealógicos detalhados, incluindo informações sobre filiação a clãs e linhagens dos residentes de Etéñitépa. A comparação dos dados da década de 70 com os censos e genealogias registrados por Maybury-Lewis em 1958 e 1962 fornece fortes evidências das relações entre crise demográfica e disputas políticas, e dos impactos a longo prazo que daí resultam sobre a organização social Xavánte.

Conduziu-se uma análise comparativa quanto ao número de homens e mulheres adultos Xavánte dos três clãs e das várias linhagens registradas por Maybury-Lewis, no final da década de 50 e início da de 60, com aqueles presentes em Etéñitépa em 1976-1977. Buscou-se investigar o que havia acontecido com aqueles que não se encontravam mais na aldeia (o número de indivíduos que havia falecido, mudado de aldeia etc.). $\mathrm{O}$ achado mais marcante é que já não havia homens integrantes das linhagens Poridza'ôno Tebe, Topdató Aiuté'mañãri e Topdató Wahi em Etéñitépa na década de 1970. Isto é, o grupo estava ainda mais homogêneo, no que se refere às facções, do que nas décadas anteriores.

Com o objetivo de revelar este padrão de modo mais claro, foram reunidos os dados em dois grupos: homens e mulheres da linhagem dominante (Poridza'õno Wamãri) e homens e mulheres das demais linhagens (Tabela 3). De um total de 23 homens e 23 mulheres Wamãri registrados nas genealogias e censos de MayburyLewis, mais da metade dos homens (17 indivíduos, ou 74\%) e das mulheres (12 indivíduos, ou 52\%) ainda viviam em Etéñitépa em 1976/1977. Para as demais linhagens, a redução foi muito maior, particularmente no caso dos homens. Somente $28 \%$ dos homens e $42 \%$ das mulheres não Wamãri registrados por Maybury-Lewis ainda viviam em Etéñitépa na década de 70. Mais marcante é o fato de que a maior causa de redução populacional entre os homens não Wamãri foi a morte, responsável por $56 \%$ da diminuição do número de indivíduos. Apenas $18 \%$ dos homens Wamãri vieram a morrer entre os períodos de 1958-1962 e 1976/1977. Como é improvável que diferentes linhagens vivendo na mesma aldeia experimentem distintas taxas de mortalidade em virtude das epidemias, é mais cabível que a redução nas linhagens não dominantes deveu-se a disputas políticas.

Os Wamãri foram, inquestionavelmente, a força política dominante em Etéñitépa na década de 70. Com base nos dados genealógicos e censitários, Flowers verificou que, em 1977, dos 28 homens com idade acima de 30 anos, 19 eram Wamãri. Curiosamente, apesar de esta linhagem haver alcançado um controle político quase total, seus membros foram forçados a enfrentar alguns problemas de ordem social, ocasionados pelo desequilíbrio entre os clãs. Segundo as regras matrimoniais Xavánte, os Wamãri, filiados ao clã Poridza'õno, supostamente deveriam tomar como esposas mulheres pertencentes aos outros dois clãs. Todavia, tantos homens Öwawe e Topdató morreram na década de 60, que poucas filhas que os Wamãri pudessem desposar foram geradas. 
Tabela 3 - Destino dos adultos Xavánte presentes em São Domingos em 1958/1962 no ano de 1977, de acordo com sexo e linhagem

\begin{tabular}{|c|c|c|c|c|c|c|}
\hline \multirow{2}{*}{ Linhagens } & \multicolumn{2}{|c|}{ Homens } & \multicolumn{2}{|c|}{ Mulheres } & \multicolumn{2}{|c|}{ Ambos os Sexos } \\
\hline & $\begin{array}{l}\text { Poridza'óno } \\
\text { Wamâri }\end{array}$ & $\begin{array}{c}\text { Demais } \\
\text { linhagens }\end{array}$ & $\begin{array}{l}\text { Poridza'óno } \\
\text { Wamâri }\end{array}$ & $\begin{array}{l}\text { Demais } \\
\text { linhagens }\end{array}$ & $\begin{array}{c}\text { Poridza'ôno } \\
\text { Wamâri }\end{array}$ & $\begin{array}{c}\text { Demais } \\
\text { linhagens }\end{array}$ \\
\hline $\begin{array}{l}\text { Vivendo em } \\
\text { São Domingos } \\
\text { em 1958/1962 }\end{array}$ & $\begin{array}{c}23 \\
(100 \%)\end{array}$ & $\begin{array}{c}25 \\
(100 \%)\end{array}$ & $\begin{array}{c}23 \\
(100 \%)\end{array}$ & $\begin{array}{c}43 \\
(100 \%)\end{array}$ & $\begin{array}{c}46 \\
(100 \%)\end{array}$ & $\begin{array}{c}68 \\
(100 \%)\end{array}$ \\
\hline $\begin{array}{l}\text { Faleceram entre } \\
1958 / 1962 \text { e } 1977\end{array}$ & $\begin{array}{c}04 \\
(17 \%)\end{array}$ & $\begin{array}{c}14 \\
(56 \%)\end{array}$ & $\begin{array}{c}07 \\
(30 \%)\end{array}$ & $\begin{array}{c}17 \\
(40 \%)\end{array}$ & $\begin{array}{c}11 \\
(24 \%)\end{array}$ & $\begin{array}{c}31 \\
(46 \%)\end{array}$ \\
\hline $\begin{array}{l}\text { Mudaram-se entre } \\
1958 / 1962 \text { e } 1977\end{array}$ & $\begin{array}{c}02 \\
(9 \%)\end{array}$ & $\begin{array}{c}02 \\
(8 \%)\end{array}$ & $\begin{array}{c}01 \\
(4 \%)\end{array}$ & $\begin{array}{c}02 \\
(5 \%)\end{array}$ & $\begin{array}{c}03 \\
(7 \%)\end{array}$ & $\begin{array}{c}04 \\
(6 \%)\end{array}$ \\
\hline $\begin{array}{c}\text { Destino } \\
\text { desconhecido entre } \\
1958 / 1962 \text { e } 1977\end{array}$ & $\tilde{\mathrm{N}}$ & $\begin{array}{c}02 \\
(8 \%)\end{array}$ & $\begin{array}{c}03 \\
(13 \%)\end{array}$ & $\begin{array}{c}06 \\
(14 \%)\end{array}$ & $\begin{array}{c}03 \\
(7 \%)\end{array}$ & $\begin{array}{c}08 \\
(12 \%)\end{array}$ \\
\hline $\begin{array}{l}\text { Vivendo em } \\
\text { Etéñitépa em } 1977\end{array}$ & $\begin{array}{c}17 \\
(74 \%)\end{array}$ & $\begin{array}{c}07 \\
(28 \%)\end{array}$ & $\begin{array}{c}12 \\
(52 \%)\end{array}$ & $\begin{array}{c}18 \\
(42 \%)\end{array}$ & $\begin{array}{c}29 \\
(63 \%)\end{array}$ & $\begin{array}{c}25 \\
(37 \%)\end{array}$ \\
\hline
\end{tabular}

Nota: Informaçóes sobre 1958/1962 derivadas de genealogias e recenseamentos conduzidos por Maybury-Lewis (1967:317-342).

Em 1976/1977, havia 11 jovens Wamãri do sexo masculino, com idade entre 15 e 25 anos, que já haviam sido iniciados. Tinham, portanto, o direito de se casar, buscando suas esposas, segundo as regras Xavánte de exogamia entre os clãs, entre as mulheres Öwawe e Topdató. Flowers observou que apenas três desses jovens conseguiram encontrar esposas. Embora houvesse sete moças Öwawe com idades entre 10 e 20 anos, três delas se casaram com homens mais velhos, e uma quarta foi destinada a um jovem que se encontrava fora da aldeia. Logo, havia apenas três moças disponíveis para o casamento, enquanto eram 11 os jovens Wamâri. Enquanto isso, a situação dos jovens Öwawe era muito diferente. Dos nove jovens deste clã entre os 15 e os 25 anos de idade, sete já estavam casados, três deles com mais de uma esposa. Havia uma tal 'abundância' de jovens mulheres Poridza'ôno Wamãri para os rapazes Öwawe desposarem, que quatro jovens homens pertencentes a este clã mudaram-se de outras aldeias para Etéñitépa e lá se casaram.

Na década de 70 , Flowers previu uma tendência de aumento do clá Öwawe, já que os homens que o integravam estavam tendo mais acesso às mulheres. Ela afirmou: "Os jovens Öwawe casaram-se com mulheres no auge de sua fecundidade e estavam claramente tendo mais filhos que os Wamãri de sua idade" (Flowers, 1983:179). A comparação dos dados dos censos de 1976/1977 e 1990 demonstra que, de fato, durante todo este período, reduziu-se o tamanho relativo dos Poridza'óno Wamãri (de $55 \%$ para $48 \%$ da população). O aumento da presença de indivíduos não Wamãri se deve, sobretudo, ao grande número de menores de 
15 anos, nascidos de 1975 a 1990, e filhos de homens Öwawe. Da década de 1970 até a de 1990, a proporção de indivíduos não Wamãri menores de quinze anos cresceu de $44 \%$ para $58 \%$.

A análise anterior demonstra que, devido a um mecanismo construído dentro da estrutura de parentesco, ou seja, à medida que os Xavánte evitem os casamentos intraclânicos, é impossível para uma linhagem crescer indefinidamente sem que tenha de lidar com algumas conseqüências adversas, originadas pela sua própria dominação política e hegemonia demográfica.

\section{Considerações finais}

Os Xavánte de Pimentel Barbosa passaram por uma severa crise demográfica nas décadas que se seguiram ao contato com a sociedade nacional brasileira nos idos de 1940. A crise foi resultado de níveis mais elevados de mortalidade, em virtude tanto das epidemias de doenças infecciosas quanto da violência, além de uma queda da fecundidade. Combinados, tais fatores ameaçaram, durante a década de 60 , a sobrevivência biológica do grupo. A partir da década de 70 , decresceu a mortalidade e aumentou a fecundidade, e a população iniciou um período de rápido crescimento.

A crise demográfica Xavánte pode não diferir muito daquelas que tiveram lugar em centenas de outros povos indígenas do Novo Mundo, desde o século XV, e que resultaram num colapso demográfico de dimensões continentais (Crosby, 1972; Ribeiro, 1977; Dobyns, 1983; Hemming, 1987; Denevan, 1992; Cook, 1998; Santos G Coimbra Jr., 2003). A literatura etnológica amazônica é repleta de relatos que descrevem a ocorrência de crises demográficas pós-contato. No entanto, essas crises só foram detalhadamente documentadas, por intermédio de dados demográficos, em um pequeno número de sociedades indígenas (Black et al., 1978; Werner, 1983; Early G Peters, 1990, 2000; Adams G Price, 1994; Flowers, 1994; Pagliaro, 2002). Para muitos deles, amazônicos ou não, a crise foi de tal modo severa, que o declínio populacional tornou-se irreversível, redundando em sua extinção biológica.

No caso Xavánte, a crise demográfica foi influenciada não somente por fatores externos, mas também por aspectos ligados à organização social. Durante o período de epidemias, acusações de feitiçaria tornaram-se mais freqüentes, exacerbando disputas intragrupais. Evidências etnográficas, assim como dados demográficos, mostram que a violência atingiu, sobretudo, os homens das facções politicamente mais fracas. O exemplo Xavánte demonstra que, embora as crises demográficas tenham sido uma experiência quase universal na história dos povos indígenas, os efeitos podem variar de acordo com características socioculturais específicas. Adicionalmente, o caso dos Xavánte indica que o impacto das epidemias 
envolve mais que a redução da população, influenciando dinâmicas sociais, como as práticas matrimoniais, mesmo décadas após a crise propriamente dita.

Apesar de todas as adversidades, os povos indígenas estão em franco crescimento no Brasil, com taxas que superam as médias nacionais. Num dado momento, nas décadas de 50 e 60, antevia-se que o futuro dos povos indígenas seria ou o desaparecimento físico e cultural ou a assimilação na sociedade envolvente, vaticínios que felizmente não se confirmaram. Nessa trajetória, as crises do contato fazem parte do passado de praticamente todos os grupos que sobreviveram (sequer sabemos quantos se extinguiram). Registrá-las e resgatálas, etnográfica e também demograficamente, contribui para uma melhor compreensão da história recente desses povos, especialmente no bojo do expansionismo ocidental. São exemplos de sofridas e íntimas, mas também, com certeza, fascinantes vinculações entre história, cultura, sociedade e demografia, como bem evidencia o processo vivido pelos Xavánte.

Agradecimentos

A pesquisa foi financiada pela Wenner-Gren Foundation, pela MacArthur Foundation e pela Fundação Oswaldo Cruz. Agradecemos também ao Conselho Nacional para o Desenvolvimento Científico e Tecnológico (CNPq) e à Comissão Fullbright. Os autores são especialmente gratos aos Xavánte, e às mulheres em particular, por sua paciência em responder a todas as suas perguntas.

1 Uma versão mais extensa e detalhada deste trabalho encontra-se como capítulo no livro The Xavánte in Transition: health, ecology and bioanthropology in Central Brazil (Coimbra Jr. et al., 2002).

\section{Referências Bibliográficas}

ADAMS, K. G PRICE, D. (Orgs.) The demography of small-scale societies: case studies from lowland South America. South American Indian Studies, 4, 1994.

BLACK, F. L. et al. Birth and survival patterns in numerically unstable proto agricultural societies in the Brazilian Amazonia. Medical Anthropology, 2:95-127, 1978. 
BUCHILLET, D. Nobody is there to hear: Desana therapeutic lamentations. In: LANGDON, E. J. M. G BAER, G. (Orgs.) Portals of Power: shamanism in South America. Albuquerque: University of New Mexico Press, 1992. p.211-230.

CHAGNON, N. A. Yanomamo: the fierce people. 3.ed. New York: Holt, Rinehart and Winston, 1983.

COIMBRA Jr., C. E. A. From Shifting Cultivation to Coffee Farming: the impact of change on the health and ecology of the suruí indians in the Brazilian Amazon, 1989. Ph.D. Dissertation, Bloomington: Indiana University.

COIMBRA Jr., C. E. A. et al. The Xavánte in Transition: health, ecology and bioanthropology in Central Brazil. Ann Arbor: University of Michigan Press, 2002.

COOK, N. D. Born to Die: disease and new world conquest, 1492-1650. Cambridge; Cambridge University Press, 1998.

CROCKER, J. C. Vital Souls: Bororo cosmology, natural symbolism, and shamanism. Tucson: The University of Arizona Press, 1985.

CROCKER, W. G CROCKER, J. The Canela: bonding through kinship, ritual, and sex. Fort Worth: Harcourt Brace, 1994.

CROSBY, A. W. The Columbian Exchange: biological and cultural consequences of 1492 . Westport: Greenwood Press, 1972.

DENEVAN, W. M. (Org.) The Native Populations of the Americas in 1492. 2.ed. Madison: University of Wisconsin Press, 1992.

DOBYNS, H. F. Their Numbers Become Thinned: native American Population dynamics in Eastern North America. Knowville: University of Tennessee Press, 1983.

EARLY, J. D. G PETERS, J. F. The Population Dynamics of the Mucajai Yanomama. San Diego: Academic Press, 1990.

EARLY, J. D. G PETERS, J. F. The Xilixana Yanomami of the Amazon. Gainesville: University Press of Florida, 2000.

EARLY, J. D. G HEADLAND, T. N. Population Dynamics of a Philippine Rain Forest People. Gainesville: University Press of Florida, 1998.

FERGUSON, R. B. Blood of the Leviathan: Western contact and warfare in Amazonia. American Ethnologist, 17:237-257, 1990.

FLOWERS, N. M. Forager-Farmers: the Xavánte indians of Central Brazil, 1983. Ph.D. Dissertation, New York: City University of New York.

GARFIELD, S. W. Indigenous Struggle at the Heart of Brazil: state policy, frontier expansion, . and the Xavante indians, 1937-1988. Durham: Duke University Press, 2001.

GOMES, M. P. Os Índios e o Brasil: ensaio sobre um holocausto e sobre uma nova possibilidade de convivência. Petrópolis: Vozes, 1988.

GRAHAM, L. R. Performing Dreams: discourses of immortality among the Xavánte of Central Brazil. Austin: University of Texas Press, 1995. 
HEMMING, J. Amazon Frontier: the defeat of the Brazilian indians. Cambridge: Cambridge University Press, 1987.

HILL, K. G HURTADO, A. M. Ache Life History: the ecology and demography of a foraging people. Hawthorne: Aldine de Gruyter, 1996.

HOWELL, N. Demography of the Dobe !Kung. New York: Academic Press, 1979.

LANGDON, E. J. M. Shamanism and anthropology. In: LANGDON, E. J. M. G BAER, G. (Orgs.) Portals of Power: shamanism in South America. Albuquerque: University of New Mexico Press, 1992a. p.1-21.

LANGDON, E. J. M. Shamanic power in Siona religion and medicine. In: LANGDON, E. J. M. G BAER, G. (Orgs.) Portals of Power: shamanism in South America. Albuquerque: University of New Mexico Press, 1992b. p.41-61.

LOPES DA SILVA, A. Dois séculos e meio de história Xavante. In: Cunha, M. C. (Org.) História dos Índios no Brasil. São Paulo: Companhia das Letras, 1992. p.357-378.

MAYBURY-LEWIS, D. Akwe-Shavante Society. Oxford: Clarendon Press, 1967.

MCGRATH, J. W. Biological impact of social disruption resulting from epidemic disease. American Journal of Physical Anthropology, 84:407-419, 1991.

NEEL, J. V. Infectious disease among Amerindians. Medical Anthropology, 6:47-55, 1982.

NEEL, J. V. et al. Studies on the Xavante Indians of the Brazilian Mato Grosso. American Journal of Human Genetics, 16:52-140, 1964.

PAgLIARO, H. A Revolução Demográfica dos Povos Indígenas: a experiência dos Kaiabi do Parque Indígena do Xingu, Mato Grosso (1970-1999), 2002. Tese de Doutorado, São Paulo: Faculdade de Saúde Pública, Universidade de São Paulo.

RIBEIRO, D. Convívio e contaminação: efeitos dissociativos da depopulação provocada por epidemias em grupos indígenas. Sociologia, 18:3-50, 1956.

RIBEIRO, D. Os Índios e a Civilização: a integração das populações indígenas no Brasil moderno. 2.ed. Petrópolis: Vozes, 1977.

ROSS, J. B. Effects of contact on revenge hostilities among the Achuara Jivaro. In: FERGUSON, R. B. (Org.) Warfare, Culture and Environment. Orlando: Academic Press, 1984. p.83-109.

SANTOS, R. V. et al. Tapirs, tractors and tapes: The changing ecology and economy of the Xavánte Indians from Central Brazil. Human Ecology, 25:545-566, 1997.

SANTOS, R. V. G COIMBRA Jr., C. E. A. On the (un)natural history of the Tupí-Mondé Indians: Bioanthropology and change in the Brazilian Amazonia. In: GOODMAN, A. H. G LEATHERMAN, T. (Orgs.) Building a New Biocultural Synthesis: politicaleconomic perspectives on human biology. Ann Arbor: University of Michigan Press, 1998. p.269-294.

SANTOS, R. V. G COIMBRA Jr., C. E. A. Cenários e tendências da saúde e da epidemiologia dos povos indígenas no Brasil. In: COIMBRA Jr., C. E. A.; SANTOS, R. V. G ESCOBAR, A. L. (Orgs.) Epidemiologia e Saúde dos Povos Indígenas no Brasil. Rio de Janeiro: Ed. Fiocruz/Associação Brasileira de Saúde Coletiva - Abrasco, 2003. p.13-47. 
SEEGER, A. Nature and Society in Central Brazil: the Suya indians of Mato Grosso. Cambridge: Harvard University Press, 1981.

WAGLEY, C. Welcome of Tears: the Tapirapé indians of Central Brazil. New York: Oxford University Press, 1977.

WERNER, D. W. Fertility and pacification among the Mekranoti of Central Brazil. Human Ecology, 11:227-245, 1983.

WOOD, J. W. Fertility in anthropological populations. Annual Review of Anthropology, 19:211-242, 1990. 


\section{A Revolução Demográfica dos Povos Indígenas: a experiência dos Kaiabi do Parque Indígena do Xingu, Mato Grosso}

\section{Introdução}

Evidências de que as populações indígenas no Brasil voltaram a crescer nas últimas décadas do século XX vêm sendo apresentadas em trabalhos recentes, contrariando as previsões de declínio apontadas por Ribeiro (1957 e 1991).

Entre a chegada dos europeus ao Brasil e o início do século XX a população indígena decresceu continuamente, reduzindo-se a cerca de 230 grupos tribais e 100 mil indivíduos (Melatti, 1993). Estima-se que durante esse período, aproximadamente $85 \%$ das línguas indígenas tenham desaparecido (ISA, 2001). Para a década de 1950, Ribeiro (1957) estimou em 143 o número de grupos tribais: 87 a menos em meio século. No final do século XX, havia 216 nações identificadas, com uma população de 350 mil indivíduos, vivendo em 561 áreas reconhecidas, mas, em sua grande maioria, não demarcadas (ISA, 2001). No recenseamento da população brasileira, realizado em 2000 pelo Instituto Brasileiro de Geografia e Estatística (IBGE), 734 mil pessoas identificaram-se como índios (Pereira, neste volume).

Alguns povos indígenas têm crescido, em média, de 3 a $5 \%$ ao ano, nos últimos decênios, entre estes, destacam-se: Nambiquara (Price, 1994); Krahô (Melatti, 1999); Bakairi (Picchi, 1994); Canela (Greene G Crocker, 1994); Xavánte de Pimentel Barbosa (Flowers, 1994, Coimbra Jr. et al., 2004); Xavánte de Sangradouro-Volta Grande (Souza G Santos, 2001); Tenetehara (Gomes, 2002); Panará (Baruzzi et al., 1994); Juruna (Pagliaro et al., 2003); Kamaiurá (Pagliaro et al., 2004); Txikão (Maia et al., 2004), assim como o conjunto dos povos do Parque Indígena do Xingu (Rodrigues, 1999).

Entre os fatores arrolados para explicar o crescimento demográfico observado destacam-se: o aumento da capacidade de resistência dessas populações às agressões de agentes infecciosos, com a menor ocorrência de epidemias; a contribuição de ações de saúde voltadas para as populações em áreas de contato antigo; e a organização dos povos indígenas em instituições que agem em sua 
própria defesa (Gomes, 1991; Melatti, 1999). Contudo, é provável que estes não tenham sido os únicos fatores responsáveis pelo crescimento verificado no final do século XX. Os altos níveis de natalidade encontrados nos últimos decênios, que entre alguns povos indígenas superaram os 50 nascimentos por mil habitantes (Pagliaro et al., 2002 e 2003), poderiam representar a recuperação de padrões reprodutivos ancestrais, existindo evidências de que nessas populações tais padrões são compatíveis com os seus anseios e necessidades estratégicas de poder e ocupação de território. Neste sentido, os povos indígenas tenderiam a ter domínio sobre o tamanho de família e de população que desejam, para atender às necessidades inerentes ao funcionamento de seus diferentes e complexos sistemas de organização sociocultural (Junqueira 6 Camargo, neste volume).

Tal constatação reforçaria a idéia de que os povos indígenas organizados podem ser soberanos quanto ao tamanho de suas populações. Muitos povos detêm práticas de restrição voluntária dos nascimentos, como ervas anticoncepcionais de efeito temporário ou definitivo, práticas abortivas naturais e mecânicas, além de prescrição do infanticídio em contingências específicas, o que lhes permitiria limitar a prole ao número desejado, como afirmam Camargo $G$ Junqueira, neste volume.

Os Kaiabi

Até meados do século XX, os Kaiabi, índios de filiação lingüística Tupi, ocupavam a região do Alto Teles Pires, desde a confluência do rio Verde até alguns quilômetros acima da barra do rio Peixoto de Azevedo, e parte da bacia do rio dos Peixes, afluente da margem direita do rio Arinos, no estado do Mato Grosso.

As primeiras notícias sobre os Kaiabi, muitas vezes confundidos com índios de outras etnias, datam do século XIX, quando expedições de mapeamento dos rios e etnográficas percorrem a região e encontram seus vestígios ou relatam referências feitas por seus inimigos tradicionais, como os Munduruku e os Bakairi (Grünberg, s/d; Travassos, 1984; Senra, 1999; Pagliaro, 2002).

Os contatos com a sociedade envolvente se intensificam no final do século XIX, quando a exploração da borracha na região do rio Tapajós se estende ao Mato Grosso, atinge as nascentes dos rios Arinos e do Paranatinga, envolvendo os índios Bakairi. Os Kaiabi do rio Verde e Alto Teles Pires começam a ser pressionados a abandonar suas terras pelos interessados na exploração dos seringais. Os conflitos, cada vez mais violentos, geram comentários de que os Kaiabi constituiriam um novo flagelo na região, como haviam sido os Bororo à época das explorações auríferas.

Os Kaiabi resistem por muito tempo e, a partir da década de 1940, por ocasião do terceiro boom da borracha e do enfraquecimento do Serviço de Proteção aos Índios (SPI), os seringais do Alto Teles Pires avançam rapidamente sobre o seu território, obrigando-os a mudar as aldeias para o médio curso deste rio. O saldo 
dessa convivência foi o deslocamento contínuo das aldeias, o fracionamento do grupo, o contágio por doenças e a depopulação.

Conforme Meliá (1993), em 1950 os Kaiabi estavam distribuídos geograficamente em três áreas: o grupo do Teles Pires, localizado entre a confluência do rio Verde e o rio Peixoto de Azevedo; o grupo da bacia do rio dos Peixes (Tatuy), afluente do Arinos; e o grupo do Sul do Pará, morador do Posto Indígena Caiabi, na região dos rios São Benedito e Cururuzinho, afluentes do Baixo Teles Pires.

A partir de 1952 uma família Kaiabi se desloca rumo ao Xingu. A decisão da mudança começou a ser cogitada a partir do encontro com os irmãos Villas Bôas, à frente da Expedição Roncador-Xingu, no rio Teles Pires, em 1949. A facilidade com que se adaptaram ao novo habitat do Xingu contribuiu para atrair outras famílias, ainda moradoras do antigo território e dos seringais, que paulatinamente foram se incorporando ao grupo inicial. Entre 1952 e 1966, registram-se migrações sucessivas de diversas famílias dos grupos do Teles Pires e do rio dos Peixes. O processo migratório² durou até 1973, quando chegam ao Parque algumas famílias que viviam no rio Cururuzinho (PA).

O Parque Indígena do Xingu (PIX) se estende da região dos formadores do rio Xingu, ao sul, e ao longo do curso deste rio até a Cachoeira de Von Martius, ao norte, nas proximidades da divisa com o Pará, compreendendo uma área de $32 \mathrm{mil} \mathrm{km} \mathrm{km}^{2}$. Com o apoio de intelectuais e políticos de expressão nacional, os irmãos Villas Bôas participaram da luta que levou à criação do Parque, em 1961, para preservar os povos da região da especulação de terras que estava ocorrendo em Mato Grosso desde o declínio do terceiro ciclo da borracha.

Além dos Kaiabi, já citados, os Juruna alcançaram a região no início da década de 1920, os Txicão (Ikpeng) em 1967, os Beiço-de-Pau (Tapayuna) em 1970 e os Kren-Akrore (Panará) em 1975. Com estes movimentos migratórios, o Parque passou a contar com 17 tribos, pertencentes a quatro maiores troncos lingüísticos: Aruak (Meinako, Waurá, Yaualapiti), Karib (Kalapalo, Kuikuro, Matipu, Nafuká e Txikão), Gê (Kren-Akrore, Metuktire, Suyá e Tapayuna) e Tupi (Aweti, Kamaiurá, Juruna e Kaiabi) e os Trumai, de língua isolada.

A partir de 1965, a então Escola Paulista de Medicina (EPM), atual Universidade Federal de São Paulo (Unifesp), passou a desenvolver um programa de saúde no PIX, com o envio de equipes médicas periódicas que procediam à vacinação e atendiam às ocorrências clínicas. Este programa assegurou uma atenção privilegiada à saúde dos índios do Xingu em relação às populações de outras áreas indígenas (Baruzzi et al., 1978). Em 1999, com a criação de 34 Distritos Sanitários Especiais Indígenas (DSEI), pela Fundação Nacional de Saúde (Funasa), a Unifesp/ EPM assumiu a coordenação do DSEI Xingu, que hoje abriga uma população próxima de 4 mil índios. 
As informações geradas durante o longo período de atuação do programa de saúde da Unifesp/EPM no Xingu possibilitaram a avaliação do comportamento demográfico dos Kaiabi para o período 1970-99, apresentada a seguir.

\section{Fontes de dados e métodos de análise}

As fontes das informações utilizadas são os livros de registro e os prontuários médicos do arquivo da Unidade de Saúde e Meio Ambiente (Usma) da Unifesp/EPM, que contêm dados demográficos e de saúde dos povos que habitam o PIX, desde a implantação do programa de saúde. O arquivo, iniciado em 1966 e alimentado até o presente momento, constitui-se num sistema de informações contínuas, inédito no país, e que até 1999 incluiu 16 povos indígenas moradores do PIX, com a saída dos Panará em 1996.

A alimentação contínua deste sistema de informações assegurou o acompanhamento efetivo da população Kaiabi durante 30 anos, permitindo, além da análise transversal da mortalidade, natalidade e migrações, o acompanhamento de coortes de mulheres em idade reprodutiva, que se configura numa análise longitudinal retrospectiva da fecundidade.

\section{Comportamento demográfico dos Kaiabi do Xingu}

Os Kaiabi organizam-se em grupos locais formados por famílias extensas, definidas como famílias nucleares, geralmente ampliadas pelo casamento dos filhos. Por ocasião da visita do etnólogo George Grünberg (s/d) ao Xingu, em 1966, os 135 Kaiabi moradores da região estavam distribuídos em sete grupos locais, e alguns moravam com os Juruna. Em 1970, havia 204 Kaiabi no PIX, vivendo em oito grupos locais e nos Postos Indígenas Diauarum e Leonardo Villas Bôas. Em 1999, somavam 758 indivíduos, distribuídos em 12 grupos locais, nos Postos de Vigilância Tuiuiu e Rio Preto e no Posto Indígena Diauarum. Integrados aos Juruna, Suyá, Txikão, Trumai e Txucarramãe, havia, neste ano, 14 homens e 2 mulheres, que, com seus filhos, totalizavam 95 indivíduos. Estes últimos estão excluídos da presente análise, em razão de sua incorporação a outras culturas.

O crescimento médio anual da população no período $1970-99$ foi de 4,5\% ao ảno. A migração foi irrelevante ao longo desses trinta anos, quando os movimentos de entradas e saídas do Parque e entre as aldeias Kaiabi e as de outros povos moradores do PIX foram constantes, mas insignificantes numericamente.

A Tabela 1 apresenta o movimento da população Kaiabi, segundo a ocorrência de eventos demográficos durante esse período. Os nascimentos (640) e os óbitos (98) registrados entre 1970 e 1999 resultaram num saldo vegetativo absoluto de 542 pessoas, responsável por $96,3 \%$ do crescimento absoluto da 
população (563). O número de imigrantes (40) superou o de emigrantes $(-19)$, tendo o saldo migratório positivo de 21 pessoas contribuído com apenas $3,7 \%$ do crescimento populacional.

Tabela 1 - Movimento da população Kaiabi do PIX, segundo eventos demográficos, 1970-1999

\begin{tabular}{|c|c|c|c|c|c|c|c|}
\hline \multicolumn{8}{|c|}{ Movimento da População Kaiabi do PIX, Segundo Eventos Demográficos, 1970-1999 } \\
\hline $\begin{array}{c}\text { Eventos } \\
\text { demográficos }\end{array}$ & $1970-74$ & $1975-79$ & $1980-84$ & $1985-89$ & $1990-94$ & 1995-99 & Total \\
\hline $\begin{array}{c}\text { População no } \\
\text { início do período }\end{array}$ & $195^{*}$ & 235 & 282 & 348 & 451 & 579 & - \\
\hline Nascimentos (+) & 43 & 68 & 82 & 109 & 141 & 197 & 640 \\
\hline Óbitos (-) & 14 & 19 & 15 & 20 & 18 & 12 & 98 \\
\hline Saldo Vegetativo & 29 & 49 & 67 & 89 & 123 & 185 & 542 \\
\hline Imigrantes $(+)$ & 13 & 0 & 0 & 15 & 9 & 3 & 40 \\
\hline Emigrantes (-) & -2 & -2 & -1 & -1 & -4 & -9 & -19 \\
\hline Saldo Migratório & 11 & -2 & -1 & 14 & 5 & -6 & 21 \\
\hline $\begin{array}{l}\text { Crescimento } \\
\text { Absoluto }\end{array}$ & $40^{\circ}$ & 47 & 66 & 103 & 128 & 179 & 563 \\
\hline $\begin{array}{l}\text { População no final } \\
\text { do período }\end{array}$ & 235 & 282 & 348 & 451 & 579 & 758 & - \\
\hline
\end{tabular}

*excluídos os nascimentos de 1970.

Fonte de dados brutos: Usma - DMP/Unifesp/EPM.

Tabela 2 - População Kaiabi do PIX e taxas médias de crescimento anual (\%)

\begin{tabular}{|c|c|c|c|c|}
\hline \multicolumn{5}{|c|}{ Populaçăo Kaiabi do PIX e taxas médias de crescimento anual (\%) } \\
\hline \multirow{2}{*}{ Anos } & \multirow{2}{*}{ Populaçăo } & \multicolumn{3}{|c|}{ Taxas Médias de Crescimento (\%) } \\
\hline & & 5 anos & 10 anos & 30 anos \\
\hline 1970 & 204 & & & \\
\hline & & 2.87 & & \\
\hline 1974 & 235 & & 3.29 & \\
\hline & & 3,71 & & \\
\hline 1979 & 282 & & & \\
\hline & & 4,30 & & \\
\hline 1984 & 348 & & 4,81 & 4,47 \\
\hline . & & 5,32 & & \\
\hline 1989 & 451 & & & \\
\hline & & 5.12 & & \\
\hline 1994 & 579 & & 5,33 & \\
\hline & & 5,54 & & \\
\hline 1999 & 758 & & & \\
\hline
\end{tabular}

Fonte de dados brutos: Usma - DMP/Unifesp/EPM. 
A Tabela 2 mostra a população Kaiabi entre 1970 e 1999 e as taxas de crescimento médio anual por períodos de cinco, dez e trinta anos. Estes dados apontam para um crescimento populacional progressivo, superando a média de $5 \%$ ao ano a partir de 1984 .

\section{Composição por idade e sexo}

As pirâmides etárias construídas para os anos de 1970 e 1999, em porcentagens, estão presentes nas Figuras 1 e 2. A estrutura da população em 1970 reflete uma situação de excepcionalidade, retratando as gerações que sobreviveram aos contatos travados com as frentes de expansão e se deslocaram para o Xingu. $\mathrm{O}$ contorno destas pirâmides ilustra o processo de transição de um regime demográfico em que altos níveis de natalidade compensam a alta mortalidade, provocando o descenso ou crescimento estável da população, para um estágio em que a mortalidade declina e a natalidade aumenta mais e se mantém elevada, configurando uma etapa de elevado crescimento e de rejuvenescimento da população.

Figura 1 - Pirâmide etária dos Kaiabi do Xingu, 1970

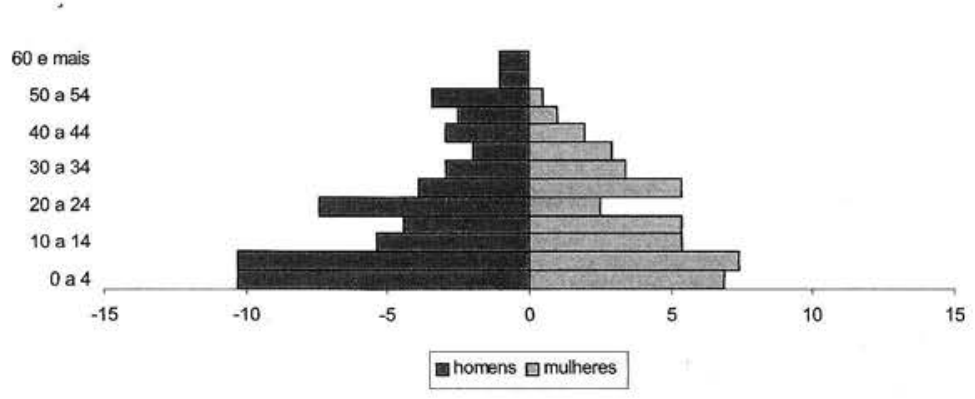

Figura 2 - Pirâmide etária dos Kaiabi do Xingu, 1999

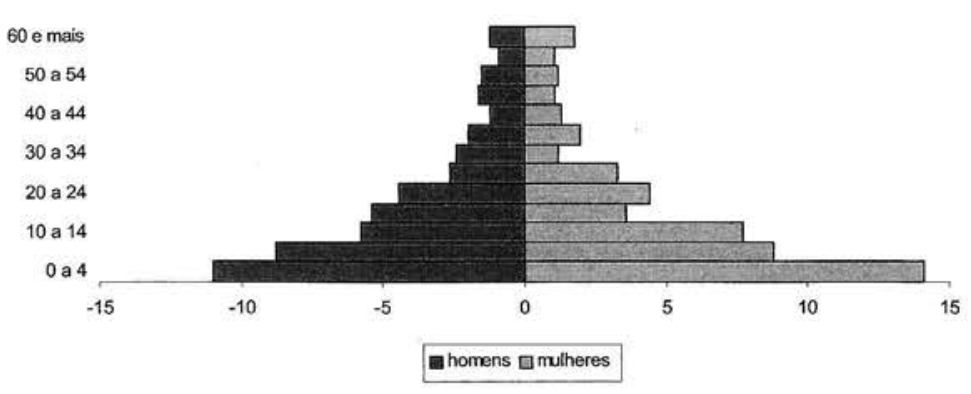


O resultado desse conjunto de fatores formou uma estrutura díspar com grandes lacunas em alguns grupos etários, embora não se deva perder de vista o fato de ser uma população pequena, na qual o impacto das pequenas mudanças absolutas pode acarretar importantes alterações relativas.

Os efeitos desse novo padrão demográfico refletem na distribuição proporcional da população por grandes grupos etários, que aponta para o aumento do peso relativo da população de 0 a 14 anos, de 45,6\% para 56,2\%, entre 1970 e 1999.

As médias de idade e as medianas estimadas para essa população, também confirmam o seu rejuvenescimento entre 1970-99. Neste período, a média de idade dos homens diminuiu de 2,6 anos, variando de 21,5 anos para 18,9 anos, e a das mulheres declinou em 1,8 ano, passando de 19,1 para 17,3 anos. Localizadas aos 17,5 anos para os homens e aos 15,5 anos para as mulheres, em 1970, as idades medianas diminuíram para 13 e 11 anos, respectivamente, em 1999, confirmando a tendência apontada pelas médias de idade no período.

Estudos demográficos sobre populações indígenas realizados nos últimos anos têm apontado para o rejuvenescimento das estruturas etárias de povos que, após um período de depopulação, retomaram altos níveis de fecundidade e estão em fase de recuperação populacional. Para tomar alguns exemplos, citam-se os Mucajai Yanomama (Early G Peters, 1990), Xavánte de Pimentel Barbosa e de Sangradouro-Volta Grande (Flowers, 1994; Souza G Santos, 2001; Coimbra Jr. et al., 2002), os Kren Akrore (Baruzzi et al., 1994), os Waurá (Pagliaro et al., 2001), os Tenetehara do Maranhão (Gomes, 2002), os Juruna (Pagliaro et al., 2003), os Kamaiurá (Pagliaro et al., 2004), e os Txikão (Maia et al., 2004).

A avaliação da composição por sexo dessa população oferece elementos importantes para a compreensão de seu processo de reprodução, sobretudo no que tange ao potencial de população disponível para garantir a reposição populacional, a formação de uniões conjugais e o desempenho de papéis e funções por gênero na sua organização social e de produção.

Tabela 3 - População Kaiabi do PIX segundo sexo, grandes grupos etários e razões de sexos, 1970-1999

\begin{tabular}{|c|c|c|c|c|c|c|c|c|c|c|c|c|}
\hline \multirow{2}{*}{$\begin{array}{l}\text { Grupos } \\
\text { Etários }\end{array}$} & \multicolumn{3}{|c|}{1970} & \multicolumn{3}{|c|}{1979} & \multicolumn{3}{|c|}{1989} & \multicolumn{3}{|c|}{1999} \\
\hline & M & F & RS & M & F & RS & M & F & RS & $M$ & F & RS \\
\hline 0 a 14 & 53 & 40 & 132,5 & 76 & 60 & 126.7 & 122 & 117 & 104,3 & 194 & 232 & 83,6 \\
\hline 15 a 49 & 53 & 46 & 115,2 & 65 & 66 & 98,5 & 97 & 84 & 115,5 & 148 & 127 & 116,5 \\
\hline $50 e+$ & 11 & 1 & 1100,0 & 12 & 3 & 400,0 & 15 & 16 & 93,8 & 27 & 30 & 90,0 \\
\hline Total & 117 & 87 & 134,5 & 153 & 129 & 118,6 & 234 & 217 & 107.8 & 369 & 389 & 94,9 \\
\hline
\end{tabular}

Fonte de dados brutos: Usma - DMP/Unifesp/EPM. 
A razão de sexos dos Kaiabi, no ano de 1970, indicava haver, em média, 134,5 homens a cada cem mulheres, no conjunto da população (Tabela 3). A superioridade numérica da população masculina se confirma em todos os grupos etários e se mantém até o final da década de 1980, mesmo que em declínio progressivo. Em 1999, já havia mais mulheres do que homens no conjunto da população, sendo a razão de sexos 94,9 . Este comportamento estaria associado ao maior número de nascimentos do sexo feminino nos últimos decênios e não à redução da mortalidade feminina ou aumento da masculina, conforme apontado na análise dos diferenciais por sexo da mortalidade descrita em Pagliaro (2002). Nas idades entre 15 a 49 anos, quando o equilíbrio numérico de homens e mulheres na população pode influenciar os padrões das uniões conjugais e da procriação, a razão de sexos ainda é favorável aos homens $(116,5)$.

\section{Mortalidade}

Para conhecer o significado da morte entre os Tupi é nẹcessário, como afirma Laraia (1986:167), "conhecer a sua concepção do mundo sobrenatural". A morte significa para esses índios "a passagem da sociedade visível dos vivos à sociedade invisível dos ancestrais", e o ingresso nesta nova sociedade dependeria do esforço dos parentes vivos, que com alguns procedimentos estariam zelando pela passagem do morto para o plano dos espíritos (Hertz, 1970, citado em Laraia, 1986:168).

Quando morre um Kaiabi, seu corpo é pintado com urucum e amarrado com os braços cruzados sobre o peito, sendo deitado em sua rede e enterrado numa cova dentro de sua casa com seus adornos e objetos, conforme descrito em Grünberg (s/d). Ainda segundo este autor, se o morto for casado (a), a viúva (o) também se pinta com urucum, corta os cabelos e, por diversos dias chora e entoa canções, na companhia dos parentes para lamentar a morte. Os Kaiabi acreditam que parte da alma da pessoa que faleceu fica ligada aos parentes vivos, que se sentem física e mentalmente ligados a ela por longo período após a morte. Recolhendo-se às suas próprias casas, os familiares falam somente o necessário e em tom baixo. À noite, as mulheres choram e entoam canções no local em que o corpo foi enterrado (Oakdale, 1996).

As taxas de mortalidade geral observadas entre os Kaiabi oscilaram entre 9,3 e 14,6 óbitos por mil habitantes, de 1970 até 1989. A partir de 1990, os níveis de mortalidade geral definem uma tendência de declínio, diminuindo para 3,5 óbitos por mil habitantes entre 1995-1999. Para neutralizar o efeito das mudanças na estrutura da população, padronizaram-se estas taxas, usando-se como padrão a estrutura populacional do período 1995-99. As taxas padronizadas assumiram valores muito próximos aos das taxas observadas, confirmando a tendência de queda. 
O declínio dos níveis de mortalidade geral dos Kaiabi estaria relacionado à maior atuação do programa de saúde da Unifesp/EPM no Xingu nesta década, em decorrência da crise vivida pela Fundação Nacional do Índio (Funai), à intensificação da formação de agentes de saúde indígena e ao programa de imunização desenvolvido desde a implantação desse programa médico.

Para os Yanomama do rio Mucajai, Early G Peters (1990) observaram uma variação dos níveis de mortalidade geral de 36,3, para 26 por mil, no período 1955-1985. Para os autores, o declínio da mortalidade entre os Yanomama poderia ser explicado pela imunidade adquirida, esforços clínicos e preventivos do programa médico levado a efeito por missionários, intensificação das campanhas de vacinação e diminuição dos contatos com a sociedade nacional.

Apenas 21 óbitos de crianças Kaiabi menores de 12 meses foram registrados dentre os 640 nascimentos ocorridos durante os trinta anos de que trata esta investigação, resultando numa taxa média de mortalidade infantil (TMI) de 32,8 por mil nascimentos vivos entre 1970 e 1999 (Tabela 4). Entre 1975 e 1984, os níveis de mortalidade infantil foram elevados, tendo as taxas oscilado entre 73,5 a 85,4 óbitos por mil nascimentos vivos. A partir de 1985, a tendência de declínio começa a se esboçar, sendo nítida até o período de 1995-99, quando a TMI é de 15,2 óbitos a cada mil nascimentos vivos, nível que pode ser considerado baixo, se comparado ao de outras populações indígenas no Brasil.

No ano de 1999, a TMI do conjunto da população do PIX foi de 29,6 por mil nascimentos vivos (Rodrigues, 1999), e a dos Waurá, também moradores do Parque, foi de 18,3 por mil (Pagliaro et al., 2001). Outras populações indígenas, como os Xavánte de Sangradouro-Volta Grande, apresentaram TMI de 87,1 por mil nascidos vivos no período 1993-1997, o que estaria associado a condições de saúde precárias (Souza G Santos, 2001).

Tabela 4 - Óbitos infantis, nascimentos e taxas de mortalidade infantil dos Kaiabi do PIX, 1970-1999

\begin{tabular}{cccc}
\hline Períodos & Óbitos Infantis & Nascimentos & TMI por mil \\
\hline $1970 / 74$ & 0 & 43 & - \\
$1975 / 79$ & 5 & 68 & 73,5 \\
$\therefore \quad 1980 / 84$ & 7 & 82 & 85,4 \\
$1985 / 89$ & 3 & 109 & 27,5 \\
$1990 / 94$ & 3 & 141 & 21,3 \\
$1995 / 98$ & 3 & 197 & 15,2 \\
\hline Total & 21 & 640 & 32,8 \\
\hline
\end{tabular}

Fonte de dados brutos: Usma - DMP/Unifesp/EPM. 
Na hipótese de que o registro de óbitos do programa de saúde da Unifesp ainda não estivesse satisfatoriamente implantado nos anos setenta e de que os óbitos infantis desta década estivessem subenumerados, seria provável que nos primeiros quinze anos do período estudado a mortalidade infantil fosse mais elevada do que o estimado e que o seu declínio tivesse sido ainda maior do que o observado.

Não se conhecem as TMI dos Kaiabi para o período de contato com as frentes expansionistas; porém, é válido supor que tenham sido muito altas. Os registros de óbitos e de nascimentos dos postos do Serviço de Proteção aos Índios (SPI) destinados aos Kaiabi são muito irregulares, não permitindo arriscar nenhuma estimativa para os quase trinta anos em que eles estiveram sob tutela do Serviço. Depoimentos de alguns Kaiabi do Xingu a respeito do período em que permaneceram nesses postos mencionam o grande número de mortes por epidemias de sarampo e de gripe, infecções respiratórias e tuberculose, enfatizando as mortes de crianças recém-nascidas.

Considerando-se o nível e a estrutura da mortalidade por idades, calculados por Pagliaro (2002), para os Kaiabi do Xingu, nos seis qüinqüênios do período 1970-1999, estimaram-se as esperanças de vida ao nascer desta população, por intermédio do Modelo Evadan (Campanário, neste volume).

Tabela 5 - Evolução da esperança de vida ao nascer dos Kaiabi do PIX, 1970-1999

\begin{tabular}{cc}
\hline Períodos & Esperança de vida (e0) \\
\hline $1970-1974$ & 48,5 \\
$1975-1979$ & 54,4 \\
$1980-1984$ & 55,1 \\
$1985-1989$ & 58,7 \\
$1990-1994$ & 63,3 \\
$1995-1999$ & 66,4 \\
\hline
\end{tabular}

Fonte de dados brutos: Usma - DMP/Unifesp/EPM.

Dos dados da Tabela 5 se depreende que o declínio dos níveis de mortalidade observado no período 1970-1999 propiciou um ganho estimado de, apŕoximadamente, 18 anos no tempo médio de vida dessa população, tendo a esperança de vida ao nascer aumentado de 48,5 anos (1970-1975) para 66,4 anos (1995-1999). 


\section{Natalidade}

Durante o período 1970 e 1999 nasceram 640 crianças vivas nas aldeias Kaiabi, sendo 312 do sexo masculino e 328 do feminino. Para o conjunto do período, a taxa bruta média de natalidade foi de 53,1 nascimentos a cada mil habitantes (Tabela 6).

Tabela 6 - Nascimentos, população e taxas brutas de natalidade (TBN) dos Kaiabi do PIX, 1970-1999

\begin{tabular}{cccc}
\hline Períodos & Nascimentos & $\begin{array}{c}\text { População } \\
\text { acumulada }\end{array}$ & TBN por mil \\
\hline $1970-1974$ & 43 & 1095 & 39,3 \\
$1975-1979$ & 68 & 1304 & 52,1 \\
$1980-1984$ & 82 & 1612 & 50,9 \\
$1985-1989$ & 109 & 2002 & 54,4 \\
$1990-1994$ & 141 & 2602 & 54,2 \\
$1995-1999$ & 197 & 3441 & 57,3 \\
\hline
\end{tabular}

Fonte de dados brutos: Usma - DMP/Unifesp/EPM.

As taxas de natalidade encontradas entre os Kaiabi do Xingu são similares às das populações indígenas que voltaram a crescer após longos contatos com nãoíndios. Entre os Xavánte de Pimentel Barbosa, Flowers (1994) encontrou uma taxa bruta média de natalidade de 51,4 nascimentos vivos por mil habitantes para o período 1977 - 1990. Entre os Xavánte de Sangradouro-Volta Grande, a TBN estimada por Santos G Souza (2001) foi de 57,7 por mil para o período 1993-1997.

Tabela 7 - Nascimentos por sexo e razões de sexo ao nascer dos Kaiabi do PIX, 1970-1999

\begin{tabular}{cccc}
\hline \multirow{2}{*}{ Períodos } & \multicolumn{2}{c}{ Sexo } & \multirow{2}{*}{ Razāo de Sexo } \\
\cline { 2 - 3 } & Masculino & Feminino & 0,9 \\
\hline $1970 / 74$ & 21 & 22 & 1,2 \\
$1975 / 79$ & 37 & 31 & 1,2 \\
$1980 / 84$ & 45 & 37 & 0,9 \\
$1985 / 89$ & 50 & 59 & 1,0 \\
$1990 / 94$ & 71 & 70 & 0,8 \\
$1995 / 99$ & 88 & 109 & 0,9 \\
\hline Total & 312 & 328 & \\
\hline
\end{tabular}

Fonte de dados brutos: Usma - DMP/Unifesp/EPM. 
As razões de sexo ao nascimento entre os Kaiabi são tão irregulares quanto as razões de muitas outras populações indígenas, podendo resultar do número excessivamente restrito da população (Tabela 7). Outro fator a ser considerado seria o infanticídio preferencial por sexo, como ocorre entre os Yanomama do rio Mucajai (Early G Peters, 1990). Os Tapirapé, quando estudados por Wagley, em 1951, possuíam famílias pequenas, de no máximo 3 filhos, sendo apenas 2 do mesmo sexo. Para manter este padrão o infanticídio é sancionado (Wagley, 1951). Para os Juruna, que durante algum tempo praticaram o infanticídio preferencial por sexo, Oliveira (1970) levanta a hipótese de que a regra de residência matrilocal - definida pela mudança do homem para a casa dos pais da esposa por ocasião do casamento - e, por conseqüência, o receio de perder homens, que saíam para casar com mulheres de outras tribos, pode ter suscitado a supervalorização do nascimento de meninas, quando estes índios manifestaram o desejo de crescer. Todavia, entre os Kaiabi do Xingu, que no passado sacrificavam gêmeos e bebês com deficiências físicas, assim como procediam os Tenetehara (Wagley, 1951) e os Nambiquara (Price, 1994), a prática de infanticídio preferencial por sexo não foi observada.

A Figura 3 mostra o comportamento das taxas de natalidade conjugado ao das taxas de mortalidade no período 1970-1999, proporcionando a visualização da importância da redução da mortalidade e do aumento da natalidade e sua manutenção em níveis altos para o processo de recuperação por que vem passando essa população.

Figura 3 - Taxas brutas de natalidade e de mortalidade dos Kaiabi do PIX, 1970-1999

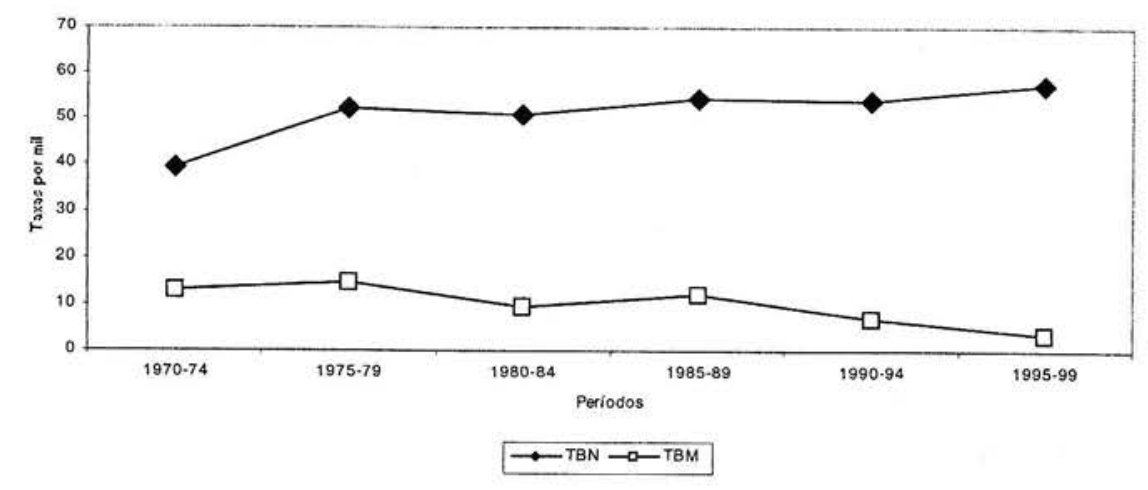

\section{Padrões culturais, fecundidade e nupcialidade}

Por volta dos doze ou treze anos de idade, os adolescentes Kaiabi passam, geralmente, por ritos de iniciação - a reclusão pubertária ou ayopot, em sua língua. 
Grünberg (s/d) observou entre os Kaiabi do rio dos Peixes que, durante este período, os rapazes permaneciam deitados em suas redes no interior de uma maloca, alimentando-se somente de chicha de milho preto (awatsi'un) e água, sendo proibidos de falar. Depois de um período, que variava de 3 a 7 dias, eram tatuados por seus pais e outros homens mais velhos numa cerimônia dirigida pelo pajé e só permitida para homens, na qual se cantava e tocava flauta. Na ocasião recebiam novos nomes. A prática do rito pubertário entre os rapazes sempre esteve ligada à tradição guerreira dos Kaiabi e, com o fim das guerras, parece ter entrado em decadência, sendo pouco freqüente no Xingu (Travassos, 1984)

Essa prática, no entanto, mantém-se para as meninas, ocorrendo após o aparecimento da primeira menstruação, quando as moças permanecem deitadas no interior da maloca, sem poder mexer em fogo, tecer algodão e conversar. Elas são banhadas pelas mães no interior da casa, obedecem a restrições alimentares e, ao final desse rito, ganham novos nomes (Travassos, 1984). Já sendo consideradas adultas, podem ter relações sexuais e assumir os compromissos do casamento, que, em geral, já estão combinados por sua família em obediência ao sistema de classificação de parentes.

Os casamentos são regidos por um sistema de parentesco conhecido na literatura antropológica como 'Iroquês' ou 'bifurca e mescla' (Junqueira, 1991; Grünberg, 1970). Este sistema distingue 'primos cruzados' e 'primos paralelos', aqueles considerados parentes 'classificatórios' e estes 'consangüíneos'. Em nível da geração de uma determinada pessoa, que é chamada de 'ego', 'primos cruzados' são os filhos das irmãs de seu pai e dos irmãos de sua mãe, que recebem o tratamento de tio e tia. 'Primos paralelos', por sua vez, são os filhos dos irmãos de seu pai e das irmãs de sua mãe, a quem 'ego' trata como a seus pais. Os parceiros conjugais preferidos são os primos cruzados ou os primos cruzados bilaterais, ou seja, os são filhos da irmã do pai e do irmão da mãe. Isto significa que o sistema mescla os irmãos do mesmo sexo dos pais de 'ego' e bifurca os irmãos de sexo diferente de seus pais (Junqueira, 1991; Gomes, 2002).

O 'levirato' ou o casamento entre tios e sobrinhas maternas era recomendado, ocorrendo, em geral, entre homens de grande prestígio, como destaca Grünberg (s/d). Entre as gerações mais velhas moradoras do PIX, verificaram-se alguns casamentos deste tipo. A 'poliginia sororal' ou o casamento de um homem com duas ou mais irmãs, também é prescrita, sendo observados diversos casamentos deste tipo entre os Kaiabi do Xingu, mesmo recentemente, mais freqüentes entre os homens de prestígio político ou religioso.

As relações sexuais entre os Kaiabi são em geral livres. Quando um rapaz tem intenção de se casar, dirige-se à mãe da parceira escolhida ou preferencial, que informa sua filha. Durante o período de 'namoro' deve presentear a sogra com caça, pesca e outros alimentos, além de objetos artesanais, como cestos e colares 
de tucum e inajá. O casamento não é precedido de nenhuma cerimônia, o rapaz se muda para a casa da esposa, onde ao novo casal é destinado um local para pendurar suas redes e seus utensílios e fazer seu fogo, configurando-se, assim, a regra de residência conhecida como matrilocal, que tem sua exceção entre os filhos de chefes de famílias extensas, que trazem as esposas para a casa do pai. O casal passa por um 'período de adaptação' antes que venham os filhos, podendo, na ocasião, mudar de nome (Grünberg, s/d).

A idade de início das uniões conjugais nas sociedades indígenas, assim como outrora se apresentava nas sociedades rurais, é, usualmente, muito jovem. Quando as regras sociais são cumpridas, as mulheres Kaiabi têm seus filhos, geralmente, aos 15 anos de idade. Mas há casos em que as mulheres iniciam a vida reprodutiva antes de completar esta idade. Como iniciam muito cedo a prática das relações sexuais e da procriação, o período reprodutivo dessas mulheres dura cerca de trinta anos, nascendo o último filho por volta dos 45 anos.

Segundo Oakdale (1996), entre os Kaiabi a concepção está relacionada ao calor e à energia do sol, sendo o pajé intermediário no encontro entre a mãe e o bebê, pois é ele quem introduz a alma da criança em sua mãe, através de seus sonhos. As crianças podem escolher entre quais casais querem nascer, e o pajé pode trabalhar para influenciar suas escolhas. A influência deste pode ser notada, também, na escolha do nome da criança; contudo, as novas gerações acreditam ser o pai que faz a alma da criança, sendo a mãe sua receptora.

A sociedade Kaiabi utiliza diferentes práticas contraceptivas, como ervas anticoncepcionais de efeito temporário ou definitivo, apesar de seu uso não ser livre e indiscriminado. Iefuká, auxiliar de enfermagem e cacique da aldeia Capivara, no Xingu, relatou que para evitar a gravidez os Kaiabi usam uma beberagem preparada com raízes de plantas, que é ingerida pela mulher durante vários dias, após as relações sexuais. Para suspender o seu efeito ingerem outra beberagem preparada com outros tipos de plantas, recuperando, desse modo, a capacidade de procriação. A anticoncepção definitiva é obtida por meio da ingestão de uma infusão de outras espécies de ervas. Para obter essas ervas, a interessada é levada pelo pajé, acompanhada por sua mãe, ao local onde nascem, o que institucionaliza o ato de anticoncepção (Iefuká Kaiabi, comunicação pessoal). Uma outra versão da anticoncepção definitiva é relatada por Oakdale (1996). Da mesma maneira como o sol nascente está relacionado à concepção, o poente liga-se à anticoncepção. Para nã́o conceber mais, o pajé prepara um banho de folhas aromáticas que é espalhado sobre o corpo da mulher, estando esta voltada para o sol poente. O aroma das folhas penetra o seu corpo, mudando o seu sangue.

Durante a gravidez, como em algumas outras situações, os pais ainda hoje obedecem a restrições alimentares, nutrindo-se de vegetais e de algumas espécies de aves, peixes e animais silvestres. A relação sexual é proibida, mas, em 
geral, cessa somente nos últimos meses da gravidez e se reinicia tão logo o filho comece a andar. A mulher continua cuidando de seus afazeres, sendo poupada do transporte de cargas pesadas.

Segundo Grünberg (s/d), entre os Kaiabi do rio dos Peixes, o nascimento da criança se dava no mato ou em uma maloca com o auxílio de mulheres mais velhas. Ao nascer, a criança era lavada com água; o cordão umbilical era cortado com um pedaço de uma espécie de taquara, que diziam auxiliar no estancamento do sangue; o umbigo era atado com uma fibra de embira, sendo untado com a seiva de uma espécie vegetal em caso de sangramento. Depois de seco, o cordão umbilical era pendurado no pescoço da criança para protegê-la, sendo, mais tarde, enterrado. Os lóbulos da criança eram perfurados com um espinho de tucum e no orifício que resulta desta operação era passado um fio de algodão (Grünberg, s/d).

Ainda segundo este autor, o pai da criança se mantinha afastado ou deitado em sua rede, na qual recebia visitas e confeccionava um pequeno arco, se a criança fosse do sexo masculino, e um boneco ou um cesto, se fosse do sexo feminino, depositando os presentes na rede destinada ao bebê. $\mathrm{O}$ pai e seu irmão, ou a mãe e sua irmã, ou o chefe da família extensa e o pajé davam nome à criança. Ao passar da infância para a adolescência ela recebia outro nome, assim como ocorria em outras fases de sua vida (Grünberg, s/d).

Segundo dados levantados durante trabalho de campo realizado no Xingu, em 2000, algumas mães amamentam as crianças até que andem com desenvoltura, e, às vezes, por mais tempo. O desmame é gradual e durante este período a criança nunca é impedida de mamar, mas sim desestimulada. Aliás, como outros povos indígenas, os Kaiabi respeitam a vontade das crianças, educando-as com independência, liberdade e respeito, interferindo somente em situações de perigo.

Entre os Kaiabi do rio dos Peixes, o infanticídio era praticado em caso de nascimento de gêmeos, sendo a primeira criança a nascer preservada e as demais sacrificadas por serem consideradas filhas de outros pais. Os recém-nascidos com deficiências físicas eram igualmente sacrificados (Grünberg, s/d). Entre os Kaiabi do Xingu observaram-se gêmeos sobreviventes, sendo alguns já adultos (Pagliaro, 2002). Quanto a deficientes físicos, não são mais sacrificados, podendo o infanticídio ocorrer, ainda, em caso de adultério ou de violência sexual.

\section{Comportamento da fecundidade no tempo}

A análise transversal ou de momento da fecundidade contemplou três períodos de dez anos: 1970-79, 1980-89 e 1990-99. O critério adotado para definir as idades do período reprodutivo buscou contemplar as exceções à regra, definindo-se 12 anos para o início do período e 49 anos para o seu término. 
As taxas de fecundidade total (TFT) estimadas apontam para o aumento progressivo da fecundidade das mulheres Kaiabi, tendo a média de filhos nascidos vivos variado de 5,7 (1970-1979), para 8,4 (1980-1989) e para 9,5 filhos (19901999), como mostra a Tabela 8.

As taxas de fecundidade por idades $\left(f_{x}\right)$ das três décadas observadas refletem a tendência de aumento, apontando para as mudanças de níveis em cada grupo etário e as modificações do padrão etário da fecundidade nesses três períodos de tempo.

Tabela 8 - Taxas de fecundidade total (TFT) e específicas por idades das mulheres Kaiabi do PIX, por períodos decenais

\begin{tabular}{cccc}
\hline $\begin{array}{c}\text { Grupos de } \\
\text { Idades }\end{array}$ & $1970-79$ & $1980-89$ & $1990-99$ \\
\cline { 2 - 4 } & $\mathrm{fx}$ & $\mathrm{fx}$ & $\mathrm{fx}$ \\
\hline 12 a $14^{*}$ & 0,1622 & 0,0619 & 0,0674 \\
15 a 19 & 0,2768 & 0,2761 & 0,3309 \\
20 a 24 & 0,2828 & 0,3248 & 0,3691 \\
25 a 29 & 0,2414 & 0,3761 & 0,3728 \\
30 a 34 & 0,0957 & 0,2921 & 0,3306 \\
35 a 39 & 0,1304 & 0,2533 & 0,2650 \\
40 a 44 & 0,0169 & 0,1059 & 0,1341 \\
45 a 49 & 0,0000 & 0,0417 & 0,0541 \\
\hline TFT* & 5,7 & 8,4 & 9,5 \\
\hline
\end{tabular}

* as estimativas consideraram o intervalo de 3 anos do grupo 12-14 anos. Fonte de dados brutos: Usma - DMP/Unifesp/EPM.

Tabela 9 - Distribuição das taxas de fecundidade por idades das mulheres Kaiabi do PIX, 1970-1999 (\%)

\begin{tabular}{cccccccccc}
\hline \multirow{2}{*}{ Períodos } & Total & & \multicolumn{8}{c}{ Grupos etários } \\
& & 12 a 14 & 15 a 19 & 20 a 24 & 25 a 29 & 30 a 34 & 35 a 39 & 40 a 44 & 45 a 49 \\
\hline $1970-1979$ & 100,0 & 13,5 & 23,0 & 23,5 & 20,0 & 7,9 & 10,8 & 1,3 & \\
$1980-1989$ & 100,0 & 3,6 & 15,9 & 18,8 & 21,7 & 16,9 & 14,6 & 6,1 & 2,4 \\
$1990-1999$ & 100,0 & 3,5 & 17,2 & 19,2 & 19,4 & 17,2 & 13,7 & 7,0 & 2,8 \\
\hline
\end{tabular}

Fonte de dados brutos: Usma - DMP/Unifesp/EPM.

O comportamento irregular dessas taxas na década de 1970 pode ser atribuído à variação dos pequenos números e a possíveis erros na estimativa das idades das mulheres nascidas antes da implantação do registro do programa de 
saúde. Nesta década, a fecundidade foi mais relevante no grupo etário de 20 a 24 anos; o nível de fecundidade das mulheres muito jovens (12 a 14 anos) foi mais elevado do que o das décadas posteriores, e o das mulheres maiores de 20 anos foi mais baixo. Para as décadas de 1980 e 1990, observaram-se mudanças no padrão de fecundidade, sendo as mulheres com idades entre 25 e 29 anos as que têm o mais elevado nível de fecundidade. A fecundidade mais concentrada nas idades jovens, observada na década de 1970, dá lugar a uma maior participação das mulheres mais velhas. Na década de 1970, as mulheres com idades até 29 anos já haviam contribuído com $80 \%$ da fecundidade total. Nas décadas de 1980 e de 1990 , as mulheres destas idades contribuíram com $60 \%$ e 59,3\%, respectivamente, verificando-se um prolongamento do período reprodutivo (Tabela 9).

\section{Comportamento da fecundidade através das gerações}

Com as informações sobre data de nascimento das mulheres e de seus filhos foi possível acompanhar, desde o início do período reprodutivo, uma coorte de mulheres com fecundidade completa e cinco coortes de mulheres que ainda não tinham completado o período reprodutivo. A Tabela 10 resume algumas características dessas coortes.

Tabela 10 - Descrição da vida reprodutiva das mulheres Kaiabi por coortes de nascimento

\begin{tabular}{|c|c|c|c|c|c|c|}
\hline Variáveis investigadas & Coorte 1 & Coorte 2 & Coorte 3 & Coorte 4 & Coorte 5 & Coorte 6 \\
\hline $\begin{array}{l}\text { Ano de nascimento } \\
\text { das mulheres }\end{array}$ & $1950-1954$ & $1955-1959$ & $1960-1964$ & $1965-1969$ & $1970-1974$ & $1975-1979$ \\
\hline Número de mulheres & 12 & 9 & 16 & 11 & 23 & 31 \\
\hline $\begin{array}{l}\text { Número de mulheres } \\
\text { que tiveram filhos }\end{array}$ & 12 & 9 & 16 & 11 & 23 & 31 \\
\hline $\begin{array}{l}\text { Ano de nascimento } \\
\text { do } 1^{\circ} \text { filho vivo }\end{array}$ & 1964 & 1970 & 1972 & 1980 & 1982 & 1989 \\
\hline $\begin{array}{l}\text { Ano de nascimento } \\
\text { do último filho }\end{array}$ & 1998 & 1998 & 1999 & 1999 & 1999 & 1999 \\
\hline $\begin{array}{l}\text { Número de filhos } \\
\text { nascidos vivos }\end{array}$ & 84 & 78 & 137 & 58 & 105 & 92 \\
\hline $\begin{array}{l}\text { Idade da măe ao nascimento } \\
\text { do último filho vivo (anos) }\end{array}$ & 44 & 44 & 39 & 34 & 29 & 24 \\
\hline $\begin{array}{l}\text { Média de filhos tidos nascidos } \\
\text { vivos até idade } \mathrm{x}\end{array}$ & 7,0 & 8,7 & 8,6 & 5.7 & 4,5 & 3,0 \\
\hline $\begin{array}{l}\text { Média de idade ao } \\
\text { nascimento do } 1^{\circ} \text { filho } \\
\text { vivo (anos) }\end{array}$ & 18.7 & 16.8 & 15,4 & 17.5 & 17.0 & 16,0 \\
\hline $\begin{array}{l}\text { Intervalo médio entre os } \\
\text { nascimentos (anos) }\end{array}$ & 2.9 & 2,8 & 2,6 & 3,1 & 2,4 & 2,5 \\
\hline
\end{tabular}

Fonte de dados brutos: Usma - DMP/Unifesp/EPM. 
A média de idade ao nascimento do primeiro filho das diferentes coortes flutuou muito, apresentando tendência de declínio progressivo a partir da coorte 4 (17,5 anos) com mulheres nascidas entre 1965-69, atingindo 16 anos na coorte 6 (a mais jovem) e apontando para o rejuvenescimento do padrão etário da fecundidade das mulheres das gerações mais jovens. Os intervalos entre os nascimentos variam entre 2,4 e 3,1 anos.

As estimativas da descendência final da coorte 1 e da coorte 2 , se considerarmos que as mulheres desta última coorte, também, já encerraram o período reprodutivo, indicam elevados níveis de fecundidade até os $40-44$ anos: 7,0 e 8,7 , em média, respectivamente (Tabela 11).

Tabela 11 - Parturições médias e acumuladas das coortes de mulheres Kaiabi do PIX, por grupos de idades

\begin{tabular}{|c|c|c|c|c|c|c|c|c|c|c|c|c|}
\hline \multirow{2}{*}{$\begin{array}{l}\text { Grupos de } \\
\text { Idades }\end{array}$} & \multicolumn{2}{|c|}{ Coorte 1} & \multicolumn{2}{|c|}{ Coorte 2} & \multicolumn{2}{|c|}{ Coorte 3} & \multicolumn{2}{|c|}{ Coorte 4} & \multicolumn{2}{|c|}{ Coorte 5} & \multicolumn{2}{|c|}{ Coorte 6} \\
\hline & $\mathrm{Fx}$ & $\begin{array}{c}\mathrm{Fx} \\
\text { acumulada }\end{array}$ & $\mathrm{Fx}$ & $\begin{array}{c}\mathrm{Fx} \\
\text { acumulada }\end{array}$ & $\mathrm{Fx}$ & $\begin{array}{c}\mathrm{Fx} \\
\text { acumulada }\end{array}$ & Fx & $\begin{array}{c}\mathrm{Fx} \\
\text { acumulada }\end{array}$ & Fx & $\begin{array}{c}\mathrm{Fx} \\
\text { acumulada }\end{array}$ & Fx & $\begin{array}{c}\mathrm{Fx} \\
\text { acumulada }\end{array}$ \\
\hline 12 a 14 & 0,167 & 0,167 & 0,222 & 0,222 & 0.438 & 0,438 & 0,091 & 0,091 & 0,217 & 0,217 & 0,129 & 0,129 \\
\hline 15 a 19 & 0.833 & 1,000 & 1.444 & 1,666 & 1,625 & 2,063 & 1,182 & 1,273 & 1,391 & 1,608 & 1,677 & 1,806 \\
\hline 20 a 24 & 1.583 & 2,583 & 1,889 & 3,555 & 1.938 & 4,001 & 1,364 & 2,637 & 1,87 & 3,478 & 1,161 & 2.967 \\
\hline 25 a 29 & 1,750 & 4,333 & 1,889 & 5,444 & 2,063 & 6,064 & 1,546 & 4,183 & 1,044 & 4,522 & & \\
\hline 30 a 34 & 1,167 & 5,500 & 1,333 & 6,777 & 1,563 & 7.627 & 1,091 & 5,274 & & & & \\
\hline 35 a 39 & 1.083 & 6.583 & 1,222 & 7.999 & 0,938 & 8,565 & & & & & & \\
\hline 40 a 44 & 0,417 & 7.000 & 0.667 & 8.666 & & & & & & & & \\
\hline 45 a 49 & 0.000 & & & & & & & & & & & \\
\hline Total & 7.000 & & 8,666 & & & & & & & & & \\
\hline
\end{tabular}

Fonte de dados brutos: Usma - DMP/Unifesp/EPM.

As parturições médias das gerações de mulheres que ainda não completaram o período reprodutivo, integrantes das coortes 3, 4, 5 e 6, indicam uma tendência de elevação da fecundidade para níveis ainda mais altos. Na coorte 3 , por exemplo, até o grupo etário 30-39 anos, a parturição média acumulada era de 8,6 filhos nascidos vivos, sendo, portanto, mais elevada do que a das coortes 1 e 2 neste mesmo grupo etário.

Assim como observado na análise da fecundidade por períodos de tempo (transversal), a avaliação das parturições médias das coortes de mulheres, até a 
idade em que puderam ser acompanhadas (longitudinal), também aponta para o aumento da fecundidade. No entanto, diferentemente do indicado no primeiro modelo de análise desenvolvido, a observação por coortes captou mudanças no calendário da fecundidade, ocorridas no sentido de rejuvenescimento de seu padrão etário, especialmente, entre as coortes que puderam ser acompanhadas por um período de tempo mais prolongado (1, 2 e 3 ) e nas primeiras idades do período reprodutivo, ao passo que a análise transversal apontou para modificações no sentido do envelhecimento.

A melhoria das condições de saúde e de sobrevivência da população proporcionada pela garantia de posse de suas terras são fatores que influenciaram a elevação da fecundidade entre os Kaiabi, que atingiu nível semelhante ao da fecundidade natural das mulheres Hutterites da América do Norte (Leridon, 1977). Os maiores aumentos se deram entre as mulheres de 15 a 24 anos, revelando uma tendência de rejuvenescimento do padrão reprodutivo. Entretanto, o impacto da melhoria das condições de saúde verificou-se, também, entre as mulheres com mais de 30 anos que, igualmente, tiveram seus níveis de fecundidade aumentados. Neste sentido, a atenção à saúde da mulher, sobretudo no período pré-natal, contribuiu para aumentar as possibilidades destas mulheres levarem as gravidezes a termo.

Outros efeitos indiretos da queda da mortalidade sobre o aumento da fecundidade podem ser mencionados, como a maior estabilidade das uniões conjugais antes interrompidas com freqüência, em razão da morte de um dos cônjuges. A aquisição do equilíbrio entre os sexos propiciou aos que se separaram ou enviuvaram maior facilidade para encontrar novos parceiros conjugais e dar continuidade à sua vida reprodutiva. O crescimento populacional em seu conjunto proporcionou um maior número de opções de casamentos prescritos pelo sistema de classificação de parentes dos Kaiabi, favorecendo as uniões antes dificultadas pela escassa oferta de parceiros.

O elevado nível de fecundidade observado entre os Kaiabi estaria associado a padrões reprodutivos caracterizados por curtos intervalos de tempo entre os nascimentos e pelo início precoce da procriação. Esta relação foi encontrada em outras sociedades indígenas como os Yanomama do rio Mucajai (Early G Peters, 1990), os Xavánte de Pimentel Barbosa (Flowers, 1994; Coimbra Jr. et al., 2002) e de Sangradouro-Volta Grande (Souza G Santos, 2001).

\section{Nupcialidade}

Com a perda populacional ocorrida durante o período de contato com as frentes de expansão, os Kaiabi ficaram com poucas opções de uniões conjugais prescritas, sendo obrigados a aceitar tipos de uniões recomendadas, mas pouco 
usuais, como as de tios e sobrinhas (levirato), ou ainda, para não descumprir as regras do sistema de parentesco, a procurar cônjuges entre os povos vizinhos. Isso ocorreu nos primeiros anos após a chegada da tribo ao PIX, quando foram registrados diversos casamentos de Kaiabi com os Juruna, Suyá, Trumai e Txikão. Tais uniões exogâmicas foram absorvidas pelo grupo, para que a reposição populacional não fosse ameaçada, mostrando como um problema demográfico pode modificar temporariamente arranjos familiares e culturais. As regras de casamento voltaram a ser operacionalizadas pelos Kaiabi, que, após um período de crescimento populacional, agora possuem diversas opções de união dentro das categorias prescritas, embora, atualmente, nem todos os casamentos obedeçam às regras tradicionais.

As informações sobre o estado conjugal analisadas a seguir referem-se ao ano de 1999 e apenas à população de 15 ou mais anos moradora das aldeias Kaiabi do PIX. As categorias de análise consideradas são: solteiros, casados por tipos de união, separados e viúvos que permaneceram sós. A Tabela 12 resume estas informações.

Entre os Kaiabi, como em outras sociedades indígenas, o celibato deliberado é raro. Em 1999, ainda permaneciam solteiros 45 homens e 20 mulheres Kaiabi, sendo a maioria com idades inferiores a 20 anos. Quanto à viuvez, quando ocorre, geralmente a viúva ou viúvo se casam novamente. Neste ano, havia 1 homem e 6 mulheres viúvas, todos com mais de 50 anos, e nenhuma pessoa separada.

Entre as 128 uniões conjugais identificadas por intermédio das genealogias, $118(92,2 \%)$ eram monogâmicas e 10 (7,8\%) poligínicas. Todos estes casamentos poligínicos envolviam um homem casado com duas irmãs, configurando-se como poliginia sororal. Cabe destacar que, entre as 138 mulheres casadas, 8 tinham menos de 15 anos; uma delas vivia em união poligínica.

Tabela 12 - Estado conjugal dos Kaiabi do PIX de 15 ou mais anos de idade, por sexo, 1999

\begin{tabular}{lccc}
\hline Estado Conjugal & Masculino & Feminino & Total \\
\hline Solteiros & 45 & 20 & 65 \\
Casados & 128 & 138 & 266 \\
Uniōes monogâmicas & 118 & 118 & 236 \\
Uniōes poligínicas & 10 & 20 & 30 \\
Viúvos & 1 & 5 & 6 \\
\hline Total & 174 & 163 & 337 \\
\hline
\end{tabular}

Fonte de dados brutos: Usma - DMP/Unifesp/EPM. 
Dentre as dez uniões caracterizadas como poligínicas, três se constituíram no início da década de 1970, duas na segunda metade da década de 1980 e cinco durante a década de 1990. Apesar de representarem somente $7,8 \%$ do total das uniões e envolverem $14,5 \%$ das mulheres casadas, a persistência desse tipo de união conjugal estaria indicando que os Kaiabi têm preferido manter seus padrões tradicionais de casamento, evitando as uniões exogâmicas.

\section{Considerações finais}

A história recente dos Kaiabi relata que a expansão da exploração seringalista para a região que ocupavam ao norte do Mato Grosso, a partir do final do século XIX, provocou o deslocamento de suas aldeias e a integração aos seringais, culminando com a mudança de uma parte do grupo para o Xingu, a partir de 1952. A mudança fracionou mais o grupo, acarretando a perda de acesso a recursos vegetais e animais que não são encontrados na região do Xingu. No entanto, a saga dos Kaiabi não impediu que sobrevivessem, por mais que tenham perdido, na mudança, práticas culturais e força política, depois recuperadas com o crescimento populacional e a posição de destaque que ocupam, hoje, na região do Diauarum, no PIX.

Em franco processo de recuperação populacional, os Kaiabi do PIX tiveram sua população aumentada de 204 para 758 indivíduos entre 1970 e 1999, correspondendo a um crescimento médio da ordem de 4,5\% ao ano. Contribuíram para este elevado crescimento populacional o desejo e a decisão de crescer, associados a diversas circunstâncias favoráveis, como a cessação de conflitos com as frentes expansionistas da sociedade nacional, a menor exposição às epidemias e a garantia do território. A assistência médica foi fundamental para a melhoria das condições de saúde, com a adoção de medidas curativas e preventivas.

Para tanto, a conjugação de fatores favoráveis ao cumprimento da fase de recuperação populacional dos Kaiabi com sucesso está colocada: o elevado número de homens e mulheres em idade reprodutiva, resultado do efeito inercial da alta natalidade e da mortalidade decrescente, favorecerá, ainda por um período de tempo, a manutenção do ritmo de crescimento da população; condições de saúde favoráveis; garantia do território e da manutenção de sua subsistência. O desafio no presente - a preservação da identidade cultural - está nas mãos dos jovens e das lideranças.

Agradecimentos

A autora agradece aos Kaiabi pela colaboração prestada durante os quatro anos em que esteve envolvida com esta investigação. 
1 Extraído da tese de doutorado homônima, defendida na Faculdade de Saúde Pública da Universidade de São Paulo, em 2002, cujo título faz referência à denominação de Adolphe Landry (Landry, 1984) para o processo de transição demográfica.

2 Uma descrição mais detalhada do processo migratório dos Kaiabi para o Xingu pode ser encontrada em Pagliaro (2005).

Referências Bibliográficas

BARUZZI, R. G.; MARCOPITO, L. F. G IUNES, M. Programa Médico Preventivo da Escola Paulista de Medicina no Parque Nacional do Xingu. Revista de Antropologia, 21:155170, 1978.

BARUZZI, R. G. et al. Os índios Panará: a busca pela sobrevivência. Anais do Encontro Nacional de Estudos Populacionais, 2:225-243, 1994.

COIMBRA Jr. et al. The Xavante in Transition: health, ecology, and bioanthropology in Central Brazil. Michigan: University of Michigan Press, 2002.

EARLY, J. D. G PETERS, J. F. The Population Dynamics of the Macujaí Yanomama. New York: Academic Press, 1990.

FLOWERS, N. M. Crise e recuperação demográfica: os Xavánte de Pimentel Barbosa, Mato Grosso. In: SANTOS, R. V. G COIMBRA Jr., C. E. A. (Orgs.) Saúde dos Povos Indígenas. Rio de Janeiro: Ed. Fiocruz, 1994. p.213-242.

GOMES, M. P. Os Índios e o Brasil: ensaio sobre um holocausto e sobre uma nova possibilidade de convivência. 2.ed. Petrópolis: Vozes, 1991.

GOMES, M. P. O Índio na História: o povo Tenetehara em busca da liberdade. Petrópolis: Vozes, 2002.

GREENE, M. E. G CROCKER, W. H. Some demographic aspects of the Canela indians of Brazil. South American Indian Studies, 4:47-62, 1994.

GRÜNBERG, F. Tentativas de análisis del sistema de parentesco de los Kayabí (Brasil Central). Separata del Suplemento Antropológico, 5:277-287, 1970.

GRÜNBERG, G. Contribuições para a Etnografia dos Kayabi do Brasil Central, s/d. Tese de Doutorado, Viena: Faculdade de Filosofia, Universidade de Viena (tradução de E. G. Wenzel G J. E. Dornstauder). São Paulo: Centro Ecumênico de Documentação e Informação.

ISA (INSTITUTO SOCIOAMBIENTAL). Povos Indígenas do Brasil. São Paulo: ISA, 2001.

JUNQUEIRA, C. Antropologia Indígena: uma introdução. São Paulo: Educ, 1991. (Série Trilhas) 
LANDRY, A. La Révolution Démographique. Etudes et Essais sur les Problèmes de la Population. Paris: Ined. (reedição da publicação de 1934), 1982.

LARAIA, R. B. Tupi: índios do Brasil atual. São Paulo: Ed. da Universidade de São Paulo, 1986.

LERIDON, H. Human Fertility: the basic components. Chicago: Chicago University Press, 1977.

MAIA, S. F. et al. Recuperação populacional dos Txicão (Ikpeng), Parque Indígena do Xingu, Mato Grosso, Brasil. In: XIV ENCONTRO NACIONAL DE ESTUDOS POPULACIONAIS (CD-ROM). Caxambu: Associação Brasileira de Estudos Populacionais - Abep, 2004.

MELATTI, J. C. Índios do Brasil. 7.ed. São Paulo/Brasília: Hucitec/Ed. da UnB, 1993.

MELATTI, J. C. Crescimento populacional. Brasil Indígena (Fundação Nacional do Índio), Ano 1, 1:24-25, 1999.

MELIÁ, B. Os Caiabi não-xinguanos. In: COELHO, V. P. (Org.) Karl von den Steinen: um século de antropologia no Xingu. São Paulo: Edusp, 1993. p.485-509.

OAKDALE, S. The Power of Experience: agency and identity in kayabi healing and political process in the Xingu Indigenous Park, 1996. Tese de Doutorado, Chicago: Chicago University.

OLIVEIRA, A. E. Os Índios Juruna do Alto Xingu. Dédalo, ano VI, jun/dez. 11-12:1-285, 1970.

PAGLIARo, H. A Revolução Demográfica dos Povos Indígenas: a experiência dos Kaiabi do Parque Indígena do Xingu, Mato Grosso (1970-1999), 2002. Tese de Doutorado, São Paulo: Faculdade de Saúde Pública, Universidade de São Paulo.

PAGLIARO, H. A mudança dos Kaiabi para o Parque Indígena do Xingu: uma história de sucesso demográfico. In: BARUZZI, R. G. G JUNQUEIRA, C. (Orgs.) História, Saúde e Cultura. Parque Indígena do Xingu. (no prelo), 2005.

PAGLIARO, $\mathrm{H}$. et al. Health Indicators and demographic behaviors of the Waurá (Aruak Indians) from 1970 to 1999. Central Brazil. In: Proceedings of the XXIV ${ }^{\text {th }}$ Iussp General Population Conference, p.42, Salvador, 2001.

PAGLIARO, H. et al. Índios Juruna (Yudjá): Comportamento demográfico e condiçōes de saúde. Parque Indígena do Xingu (1970-1999). In: VII CONGRESSO BRASILEIRO DE SAÚDE COLETIVA, Resumos, p.620. Brasília: Associação Brasileira de Saúde Coletiva - Abrasco, 2003.

PAGLIARO, H. et al. Comportamento demográfico dos Índios Kamaiurá, Parque Indígena do Xingu, Mato Grosso, Brasil. In: XIV ENCONTRO NACIONAL DE ESTUDOS POPULACIONAIS (CD-ROM). Caxambu: Associação Brasileira de Estudos Populacionais - Abep, 2004.

PICCHI, D. Observations about a Central Brazilian indigenous population: the Bakairi. South American Indian Studies, 4:37-46, 1994.

PRICE, D. Notes on Nambiquara demography. South American Indian Studies, 4:63-76, 1994. 
RIBEIRO, D. Prefácio. In: GOMES, M. P. Índios do Brasil: ensaio sobre um holocausto e uma nova possibilidade de convivência. 2.ed. Petrópolis: Vozes, 1991. p.9-13.

RODRIGUES, D. Relatório de Atividades. Distrito Sanitário Especial Indígena do Xingu. São Paulo: Departamento de Medicina Preventiva/ Unidade de Saúde e Meio Ambiente/ Universidade Federal Paulista - Escola Paulista de Medicina, 1999.

SENRA, K. Kaiabi. Disponível em http://www.socioambiental. org/website/epi/kaiabi. Htm. Consulta em 6 de julho de 2000, 1999.

SOUZA, L. G. G SANTOS, R. V. Perfil demográfico da população indígena Xavánte de Sangradouro - Volta Grande, Mato Grosso (1993-1997), Brasil. Cadernos de Saúde Pública, 17:355-366, 2001.

TRAVASSOS, E. Xamanismo e Música entre os Kayabi, 1984 Dissertação de Mestrado, Rio de Janeiro: Faculdade de Filosofia, Universidade Federal do Rio de Janeiro.

WAGLEY, C. Cultural influences on population: a comparison of two Tupi tribes. Revista do Museu Paulista, 5:95-104, 1951. 


\section{Estimativas de Fecundidade e de Mortalidade de Populações de Pequena Escala Através de um Modelo Demográfico}

\section{Introdução}

Objetiva-se, aqui, explicar o funcionamento de um modelo demográfico para estimar a fecundidade e a mortalidade de populações de pequena escala, o Modelo Evadan (Campanário, 2002), usando como exemplo de sua explicação, uma população indígena - os Kaiabi do Parque Indígena do Xingu - e verificar a possibilidade de sua aplicação a outras populações indígenas, também de pequeno volume populacional (Campanário, 2004). O modelo trabalha com a população por sexo e idades e os três componentes demográficos básicos - fecundidade, mortalidade e migração - e é uma variante do Método dos Componentes Demográficos, amplamente empregado pelos demógrafos, com diferentes fins.

A fonte de informação é a base de dados epidemiológicos e demográficos desse povo, construída, sistematizada e analisada por Pagliaro (2002, neste volume), para o período 1970-1999, por meio dos prontuários médicos individuais, preenchidos por ocasião dos exames médicos realizados periodicamente pelas equipes do programa de saúde da Universidade Federal de São Paulo/Escola Paulista de Medicina (Unifesp/EPM), sem interrupções desde 1965 (Baruzzi et al., 1978).

Essa autora estima taxas dos eventos populacionais de forma direta, com os dados brutos, sem ajustes ou alterações, que resultam em grandes oscilações, que podem ser explicadas pelo fenômeno estatístico dos pequenos números, mas que, apesar da grande confiabilidade dos dados utilizados, suscitam dúvidas com respeito à qualidade de seus resultados. Por outro lado, os Kaiabi, acuados, em vias de extinção e obrigados a emigrar de sua terra originária, longe da atual, provavelmente definiram estratégias específicas de sobrevivência e de recuperação populacional, muitas delas apenas intuídas pelos pesquisadores. Estes dois fatores provocaram dúvidas acerca da qualidade das taxas, como por exemplo, se seriam reais as taxas totais de fecundidade, crescentes entre 1970 e 1999 e extremamente altas no final do período, em torno de dez filhos por mulher. Caberia ainda questionar se tais taxas seriam o resultado de uma estratégia exitosa de sobrevivência dos 
Kaiabi ou se tudo não passaria de uma miragem derivada dos pequenos números. Como contraponto aos resultados de Pagliaro (2002), aplica-se neste trabalho uma técnica indireta: um modelo demográfico que gera populações teóricas e compara os dois resultados.

\section{Descrição do modelo demográfico}

Um modelo, no sentido aqui utilizado, é

uma das espécies fundamentais de conceitos científicos, mais precisamente o que consiste na especificação de uma teoria científica para descrever uma zona restrita e específica do campo coberto pela própria teoria. O modelo não é necessariamente de natureza mecânica (ainda que os modelos mecânicos tenham parecido indispensáveis para a ciência do século XIX) e tampouco tem por necessidade o caráter de visualização que às vezes foi exigido. A ciência moderna generalizou a noção de modelo precisamente para subtrair estas limitações e fazê-la servir para finalidades maiores. (Abbagnano, 1966:813)

O mapa de transportes de uma cidade, por exemplo, é um modelo, pois, para desenhá-lo, foi necessária a existência de uma teoria explicativa (implícita ou explícita) sobre o funcionamento desta cidade em um de seus aspectos restritos ou específicos, qual seja, o transporte. O mapa 'descreve visualmente' o funcionamento dos transportes dessa cidade. Inúmeros outros modelos podem ser construídos para esta mesma cidade, especificando seus mais variados aspectos. $\mathrm{O}$ modelo demográfico aqui empregado descreve matematicamente uma população qualquer no tempo, ou seja, sua dinâmica, utilizando, em seu bojo, outros submodelos - os de fecundidade, mortalidade e migrações.

\section{O Método dos Componentes Demográficos para projetar e analisar populações}

Há uma estreita relação entre os 'modelos demográficos' - como o Evadan -, o Método dos Componentes Demográficos e as projeções populacionais.

Para projetar populações, a técnica mais cômoda e rápida é o ajuste de fuṇções matemáticas, geométricas ou similares às tendências passadas de crescimento da população. No entanto, esse tipo de técnica não leva em conta que a dinâmica demográfica se explica, especialmente, por intermédio de três componentes demográficos fundamentais - mortalidade, natalidade e migrações -, além de outras, como as razões de sexo ao nascimento. Tais variáveis demográficas possuem uma relativa autonomia entre si, uma vez que dependem de diferentes fatores socioeconômicos, culturais, biológicos e, conseqüentemente, apresentam 
tendências muitas vezes conflitantes. Por esse motivo, o Método dos Componentes Demográficos, que projeta separadamente estas variáveis e as combina num todo coerente valendo-se de uma população-base, é mais confiável e robusto que as funções matemáticas, nas quais esses componentes se escondem como numa 'caixa preta'. Mas tal método exige, a fim de ser operacionalizado, dados sobre população, mortes e saldos migratórios, por sexo e grupos etários, e taxas de fecundidade por idade das mães, informações nem sempre disponíveis ou com a qualidade desejada, o que torna sua utilização relativamente complexa.

O Modelo Evadan, mesmo quando analisa populações no pretérito, funciona como se estivesse elaborando uma projeção demográfica. Através de relações matemáticas bem estabelecidas entre o comportamento da mortalidade, fecundidade, migração e a população, cria-se um todo coerente; em suma, um modelo. Neste, uma simples alteração, em qualquer uma das variáveis, provoca mudanças no total populacional e em sua composição por sexo e grupos etários e, por conseguinte, nas taxas que medem os níveis das outras variáveis. Existem, portanto, relações precisas e mensuráveis entre essas variáveis e o contingente e a estrutura por sexo e idades das populações. Qualquer modelo que tenha origem em componentes demográficos, apesar de suas especificidades, fundamenta-se nessas relações mútuas formais.

Para entender tais relações de forma sucinta, pode-se recorrer ao conceito de coorte ou geração, que mostra intuitivamente como a estrutura etária específica para cada população se associa a tais componentes. Ao dividir a população em três segmentos, o dos filhos ou crianças e adolescentes, equivalente ao grupo etário 0-14 anos, o dos pais, do grupo 15-64 anos e o dos avós, grupos de 65 e mais anos, é fácil mostrar que a estrutura das populações em que existem mais filhos que pais e mais pais que avós, tem forma de pirâmide, e isso porque os pais têm mais filhos que seu próprio número e os avós, que no passado tiveram também filhos, o fizeram com o mesmo comportamento reprodutivo. Logo, ao examinar a distribuição de uma população por idades, pode-se inferir qual a fecundidade das mulheres, se a mesma está ou não diminuindo e inclusive quais os níveis aproximados de mortalidade e de fluxos migratórios, visto que todos esses componentes determinam, em última instância, a distribuição etária da população. Em resumo: a um dado conjunto de taxas de mortalidade, de fecundidade e de saldos migratórios por grupos etários, corresponde uma única e específica estrutura etária de população.

Déssa forma, ao introduzir uma estrutura populacional por sexo e idades no Modelo Evadan, este pode estimar as taxas dessa população - ainda que não existam dados disponíveis sobre mortalidade, migrações ou número de filhos. $\mathrm{O}$ inverso é também verdadeiro, isto é, ao introduzir no modelo determinadas taxas associadas à determinada população, geram-se populações com estruturas etárias delas derivadas. Deve-se assinalar que a dinâmica da população e das variáveis 
demográficas depende, como já se afirmou anteriormente, de fatores extrademográficos cuja análise é imprescindível para entendê-las e projetar suas tendências futuras, apesar de tais fatores, aqui, não serem objeto de estudo.

Para que se compreenda de maneira mais precisa como funciona o modelo, deve-se ter em conta que ele utiliza populações com anos terminados em zero e cinco, como por exemplo, 1970, 1975 e 1980, e as taxas qüinqüenais desses períodos, 1970-1975, 1975-1980. Suponha-se agora um período, para exemplificar, o de 1970-1975, e uma situação ideal em que os dados do registro civil sejam de boa qualidade, completos, e a população grande. Ao embutir no modelo a população de 1970, por sexo e grupos etários, as taxas de fecundidade por grupos etários das mães, as de saldos migratórios e as probabilidades de sobrevivência, ambas por sexo e grupos etários, todas referentes ao período 1970-1975, o modelo é capaz de gerar, com base nessa população, uma população teórica de 1975, idêntica à real deste mesmo ano. Isso porque, como se afirmou antes, o modelo funciona como se estivesse projetando uma população com o Método dos Componentes Demográficos.

\section{Como funciona o modelo com dados completos}

Veja-se, agora, como o modelo se vale de cada uma dessas variáveis, começando com a mortalidade. Nos casos ideais, chega-se às probabilidades de sobrevivência, por sexo, do período em análise, valendo-se das taxas específicas de mortalidade por sexo, que são obtidas, por sua vez, pelos dados de mortes do registro civil e da população dos censos demográficos. Para entender o significado exato dessas probabilidades, assim como o de Esperança de Vida ao Nascer $\left(e_{0}\right)$, é necessário entender o conceito de 'tábua de vida'. No entanto, como este tema escapa aos objetivos do estudo, aqui se vai apenas exemplificar o que interessa para um melhor entendimento do modelo demográfico.

Assim, a população entre 10 e 15 anos numa data específica, 30 de junho de 1970, será, cinco anos depois, no dia 30 de junho de 1974, a população entre 15 e 20 anos, menos as pessoas que morreram neste período, supondo-se por ora um saldo migratório nulo. A variável que nos interessa, numa tábua de vida, para projetar cada grupo etário é, como se afirmou, a relação de sobrevivência, definida como a probabilidade de sobreviver das pessoas de determinado grupo etário, por exemplo, o de 10-14 anos, nos próximos cinco anos, e se simboliza com ' $\mathrm{S}_{50-15}$ ' e varia, como qualquer probabilidade, entre 0 e 1 . Suponha-se agora que o grupo 10-14 seja constituído por 100 mil adolescentes no dia 30 de junho de 1970 e a probabilidade de sobrevivência do mesmo seja de $98 \%$, ou ${ }_{5} \mathrm{~S}_{10-15}=0,98$. Isto quer dizer que multiplicar esta probabilidade por esta geração de adolescentes resulta na população de 15-19 anos cinco anos adiante, ou seja, no dia 30 de junho de 1974: 
$1970 / 74$

$$
{ }_{5} \mathrm{P}_{10-15}=100.000 * 0,98=98.000
$$

No caso do último grupo etário, que é aberto, ou seja, tem a forma, por exemplo, de 75 e mais anos, o cálculo é feito de forma diferente, com uma fórmula específica. Algo similar ocorre com o grupo 0-4 anos em 30 de junho de 1974, pois para projetá-lo se necessita do número de nascimentos ocorridos durante o período 1970-1974, visto que estas crianças foram nascendo no decorrer deste período e ainda não podiam, claro está, existir em 30 de junho de 1970, o que vai ser examinado adiante.

As 'esperanças de vida ao nascer' $\left(\mathrm{e}_{0}\right)$ e as 'probabilidades de sobrevivência' são os produtos finais das tábuas de vida e, em termos práticos, os dados de mortalidade mais importantes de que o modelo necessita. Como o ponto de partida empírico das tábuas de vida é sempre as taxas de mortalidade por idades e sexo, elas são em realidade uma transformação adequada dessas taxas numa medida sintética que tem a qualidade de não estar afetada pela estrutura etária populacional e de serem úteis para projetar um a um os grupos populacionais por sexo e idades. Como é possível obter estas probabilidades para todos os grupos etários, a partir das tábuas de vida, basta multiplicar as mesmas pela população dos grupos etários correspondentes da população de partida e teremos a população projetada cinco anos adiante e assim sucessivamente.

Para estimar os nascimentos, entra em cena, agora, a fecundidade. Primeiramente, como já se tem a população feminina em 1970 e em 1974, calculase, por interpolação, a população feminina de cada grupo fértil qüinqüenal (15-19, $20-24, \ldots, 45-49$ ) do dia 30/06/1972, a saber, na metade do período 1970-1974. O número de mulheres (PF) nesta data e de determinado grupo de idade, digamos, 15-19 anos, multiplicado pela Taxa Específica de Fecundidade média deste grupo, $\mathrm{f}_{(\mathrm{x}-5)^{\prime}}$, resulta no número médio anual de nascimentos projetados deste grupo, de crianças de ambos os sexos. Se multiplicarmos este número por cinco, obteremos o número total de filhos tidos nascidos vivos desse grupo de mulheres no período 1970-1974. Em síntese, para projetar o número de nascimentos totais do período (simbolizado universalmente por B), basta calcular a somatória das taxas específicas multiplicadas pelas respectivas populações femininas médias e multiplicar o resultado por cinco:

$$
\left.\left.\mathrm{B}_{(\mathrm{H}+\mathrm{M})}^{70-74}=5^{*} \quad \sum_{\mathrm{x}=15}^{45} \mathrm{f}_{(\mathrm{x}-5)}^{31 / 12 / 72}{ }^{30 / 6 / 70} \mathrm{PF}_{(\mathrm{x}-5)}^{30 / 6 / 74}+\mathrm{PF}_{(\mathrm{x}-5)}\right) / 2\right\}
$$


Para o cálculo dos nascimentos masculinos e femininos separadamente, basta multiplicar B pela razão de sexo, ou seja, a proporção de homens que nascem com respeito a mulheres, geralmente um pouco maior para o sexo masculino. Em termos percentuais, adota-se o valor de $51 \%$ quando não há à disposição dados empíricos confiáveis.

Para obter a população entre 0 e 5 anos no dia 30/6/1974, basta multiplicar a relação de sobrevivência dos nascidos entre 30/06/1970 e 30/06/ 1974 até o grupo 0-4 em $1974\left({ }_{5} S_{b}\right)$ pelos nascimentos do período (no caso, para ambos os sexos):

${ }_{5}^{30 / 6 / 74} \mathrm{P}_{0}={ }_{5}^{70-74} \mathrm{~S}_{\mathrm{b}} \cdot \begin{gathered}{ }^{70-74} \\ \mathrm{~B}\end{gathered}$

Para 'projetar' por mais anos, toma-se a população em 1975 como base e se continua o processo.

Os movimentos migratórios não são registrados oficialmente, nem no Brasil nem na maior parte dos países, como ocorre com nascimentos e mortes. Podem ser obtidos de forma indireta, por diferença entre nascimentos, mortes e as populações dos períodos estudados ou por intermédio de dados censitários ou pesquisas amostrais, em que se indaga a origem das pessoas de determinado município, há quanto tempo vivem nele etc. O modelo, contudo, calcula-os na forma de saldos absolutos por grupos etários e sexo, com base nas diferenças entre nascimentos, mortes e população existente nas duas pontas de um período qüinqüenal. Estes totais são submetidos às mesmas relações de sobrevivência por idades da população em estudo.

\section{Como funciona o modelo com dados incompletos}

Caso não se disponha de dados confiáveis de mortalidade, fecundidade e migrações por sexo e grupos etários, ou eles sejam oscilantes como ocorre com os dados de populações indígenas, ou seja, caso a situação não seja ideal como a analisada no ponto anterior, o modelo pode trabalhar com outros modelos mais específicos dessas variáveis, segundo o caso e a necessidade, para estimar esses dados detalhados.

Com a mortalidade, por exemplo, há tábuas-modelo desenvolvidas pela Organização das Nações Unidas (United Nations, 1955) ou por demógrafos como Coale e Demeny (1985), entre outros, e o conhecido 'Modelo Brasil' (IBGE, 1981), adaptado ao nosso país, desenvolvido pelo Instituto Brasileiro de Geografia e Estatística (IBGE), que parte de uma série de dados de mortalidade de várias cidades e regiões que apresentavam dados fidedignos na data em que foram criados (1981). 
Ele apresenta, depois de múltiplos procedimentos de padronização com funções matemáticas, uma série de 25 tábuas de mortalidade para cada um dos sexos, que vão de níveis altos - em torno de 20 anos de esperança de vida - até níveis baixos, chegando a quase 80 anos no caso das mulheres. Mais recentemente foi desenvolvida outra série de tábuas-modelo pela Fundação Seade (Fundação Sistema Estadual de Análise de Dados), para o Ministério da Saúde (Campanário G Borlina, 2004), e que leva em conta, sobretudo, a diminuição muito acentuada da mortalidade infantil ocorrida no país a partir da década de 1980 e o aumento da mortalidade em idades jovens adultas, mormente a masculina. O presente modelo se vale destas duas últimas séries de tábuas porque elas são adaptadas às condições demográficas e epidemiológicas do Brasil.

As tábuas-modelo podem ser empregadas de diferentes maneiras. Dos Kaiabi, por exemplo, sabe-se, com exatidão, quantos morreram, com que idade e em qual ano, entre 1970 e 2000; porém, em virtude das poucas mortes, as taxas, calculadas diretamente por grupos etários, imprescindíveis, em princípio, para o cálculo da mortalidade infantil ou da $e_{0}$, oscilam muito. Este inconveniente pode ser superado pelo cálculo de taxas brutas de mortalidade, que dividem o número total de mortos num determinado período pela população média do mesmo período e, quanto maior o período, melhor a estimativa, pois haverá mais mortos no numerador e menos oscilações. Introduz-se em seguida, no modelo, relações de sobrevivência do modelo de mortalidade do IBGE, quando o período está entre 1970 e 1980 e o da Fundação Seade, quando está de 1980 para frente. Estas probabilidades estão associadas a determinado nível de $\mathrm{e}_{0^{\prime}}$ inicialmente arbitrário. Como resultado, o modelo vai calcular qual a Taxa Bruta de Mortalidade (TBM) que corresponde a tal nível escolhido de $e_{0}$. Esta TBM não vai ser igual, necessariamente, à calculada empiricamente, entretanto, mediante tentativas de erros e acertos, chega-se finalmente a um nível de $e_{0}$ que corresponde à TBM calculada empiricamente. Dessa forma, parte-se das TBM e chega-se a relações de sobrevivência compatíveis com os dados de mortalidade disponíveis dos Kaiabi.

Com respeito à fecundidade, o modelo tem em seu bojo estruturas associadas com níveis de Taxa de Fecundidade Total (TFT) (Campanário G Godinho, 1997), mas, por causa da especificidade da parturição das mulheres Kaiabi, particularmente pelo seu elevado nível de fecundidade, foi aplicada aqui uma estrutura média do período 1970-2000, obtida com base nas apresentadas por Pagliaro (2002), para os períodos 1970-1980, 1980-1990 e 1990-2000, com o objetivo de evitar, de novo, as oscilações nas taxas.

Os saldos migratórios, neste caso, só podem ser obtidos por diferença entre nascimentos, mortes e populações por sexo e idades entre diferentes períodos, com tentativas de erros e acertos. 
Já se afirmou anteriormente que, numa situação ideal, em que os dados do registro civil sejam de boa qualidade e a população grande, a projeção do modelo para determinado ano deve ser idêntica à real. Com populações oscilantes como a dos Kaiabi, isso não ocorre nunca, pois o modelo suaviza as taxas e as populações. Nesse caso então o objetivo é o de 'projetar' uma população que seja a mais próxima possível da real, mas sem o inconveniente das oscilações. A proximidade ou não da estrutura etária da população projetada com respeito à real é medida matematicamente com a técnica de mínimos quadrados. No entanto, o total populacional obtido indicado pelo modelo deve ser o mais próximo possível do total empírico, uma vez que esse número é bastante confiável.

Há casos em que as populações, além de pequenas, não têm dados sobre mortalidade, fecundidade ou migrações. Nessa situação se necessita como mínimo da população por sexo e idades e não cabe outra opção, senão a de introduzir no modelo taxas de fecundidade, relações de sobrevivência e saldos migratórios totalmente arbitrários, valendo-se de algum modelo escolhido, e, por tentativas de erros e acertos, aproximar-se o máximo possível dessa população.

\section{Resultados para anos anteriores a 1970}

O objetivo aqui é o de aplicar o modelo à população Kaiabi, em 1970, com uma única informação, a de sua população por sexo e idades neste ano, na suposição de que não exista nenhum outro dado disponível. Dessa forma tenta-se obter, de maneira aproximada, taxas anteriores a 1970. Essa forma de utilização do modelo pode ser útil no caso de outras etnias com pequenas populações e carentes de registro contínuo de eventos vitais.

Fundamentando-se em um ponto remoto no passado (1920) e introduzindo taxas de fecundidade, de mortalidade e de saldos migratórios a partir deste ano e até 1970, chega-se, por intermédio de tentativas de erros e acertos, a uma população teórica a mais próxima possível da recenseada para 1970, cujos efetivos são bastante confiáveis. Neste momento, o modelo já indica os níveis aproximados de fecundidade, mortalidade e migrações em anos próximos anteriores a 1970. Esta informação é relativamente grosseira; contudo, seu objetivo é o de ter uma idéia aproximada da dinâmica demográfica anterior ao período de estudo (1970-1999), totalmente desconhecida até o momento. Na Tabela 1, podem ser examinadas algumas características da população Kaiabi no período 1965-1970: 7,5 filhos por mulher de TFT, esperança de vida ao nascer de aproximadamente 42 anos, razão de sexo ao nascer, adotada arbitrariamente, de 0,512 (105 nascimentos masculinos para 100 femininos), natalidade de 49 por mil, mortalidade de 21 por mil e saldo migratório negativo de $-1,8$ por mil. Chama a atenção a pequena proporção de mulheres na população em 1970 (44\%). Para que se estabeleçam as cifras e taxas 
anteriores, condizentes com a população de 1970 e sua estrutura etária e por sexo, o modelo teve de assumir que a migração foi essencialmente negativa no passado e quase que exclusivamente feminina (88\%). Pode-se comparar a população do modelo com a censitária em 1970 na Figura 1. Cumpre aqui observar que as oscilações na população Kaiabi recenseada são grandes e tais dados são apenas uma aproximação da realidade, já que até o momento temos somente um ponto de observação (1970). Deve-se ressaltar que no período anterior a 1970 o povo Kaiabi estava sofrendo um processo de extinção que só pôde ser debelado graças à mudança de uma parte do grupo para o PIX, na década de 1950. Muito do que ocorreu antes de 1970 ainda não pôde ser desvendado e talvez nunca venha a sê-lo.

Figura 1 - Comparação entre a população gerada pelo modelo e a censitária na etnia Kaiabi, 1970

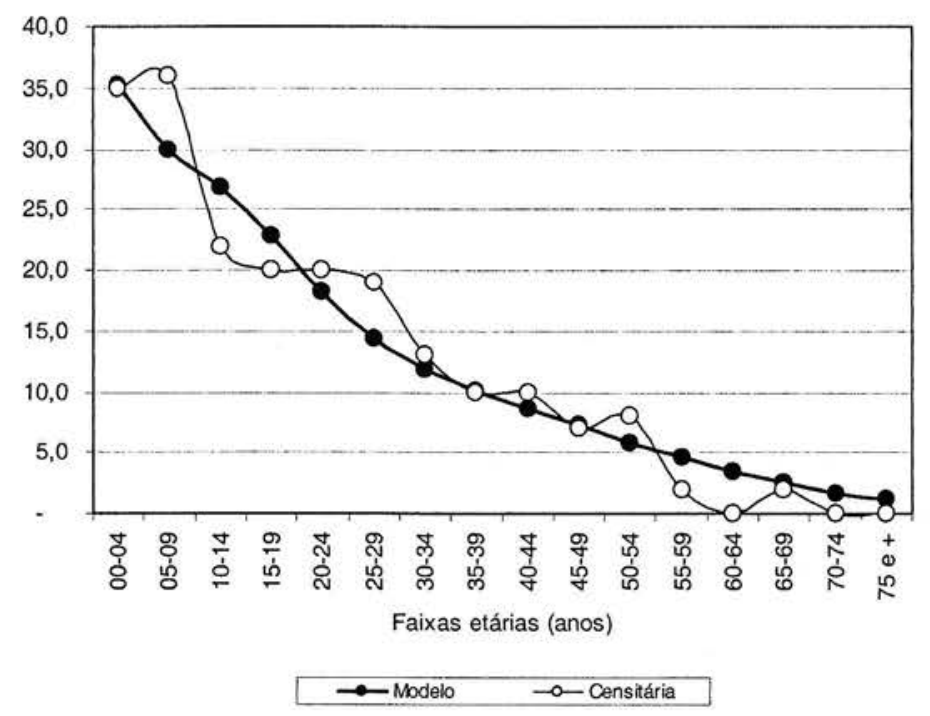

Fonte: Usma - DMP/Unifesp - EPM e Modelo Evadan.

\section{Resultados para o período 1970-2000}

O primeiro passo para a análise do período que mais interessa (19702000) é a introdução, no modelo, da população Kaiabi recenseada, por grupos qüinqüenais de idades, nos diferentes anos terminados em zero e cinco (1970, 1975, ... 2000), e esta última, não disponível, foi obtida pela projeção geracional, com base nas populações por sexo e grupos etários simples de 1995, 96, 97, 98 e 99. Estas são as principais informações que o modelo exige, como se sabe. 
Pelas tentativas de erros e acertos, vão-se introduzindo taxas de mortalidade, fecundidade e de saldos migratórios, no período 1970-1975, de tal forma a se chegar a uma população paulatinamente próxima à de 1975 . No momento em que essas duas populações passam a ser idênticas, pode-se afirmar que os valores de fecundidade, mortalidade e de saldos migratórios são possivelmente até mais 'reais' que os calculados de forma direta, pois nesta última estão intervindo as oscilações dos pequenos números, problema não existente no modelo. Este tem a vantagem adicional de que todos os dados por ele gerados são, por definição, coerentes entre si e detalhados por idades. A esperança de vida ao nascer também pode ser obtida, tarefa impossível no caso da medição direta, por causa, uma vez mais, dos pequenos números envolvidos.

As taxas obtidas indiretamente pelo modelo se aproximam bastante das calculadas por Pagliaro (2002) de forma direta, e as tendências observadas vão no mesmo sentido (aumento da fecundidade no período analisado, diminuição da mortalidade, diminuição da diferença de porcentagem entre homens e mulheres etc.), fato que reforça a robustez dos dados diretos utilizados por Pagliaro e do modelo aqui exposto (Tabelas 1, 2, 3 e 4; Figuras 2, 3 e 4). A esperança de vida ao nascer, na Figura 4, só existe em seu cálculo indireto via modelo porque o pequeno número de mortes impede seu cálculo por métodos diretos.

Tabela 1 - Características demográficas aproximadas da população da etnia Kaiabi no período 1965-1970, inferidas pelo modelo tendo como base a população de 1970

\begin{tabular}{lc}
\hline Taxa de Fecundidade Total & 7,50 \\
\hline Esperança de vida ao nascer & 42,46 \\
Razão de Sexo adotada $(\mathrm{h} /(\mathrm{h}+\mathrm{m}))$ & 0,512 \\
Natalidade (*1000) & 48,83 \\
Mortalidade (*1000) & 20,73 \\
Migrações (*1000) & $-1,83$ \\
Crescimento (*1000) & 26,27 \\
Mulheres na população (\%) (1970) & 43,6 \\
\hline
\end{tabular}

Foṇte: Usma - DMP/Unifesp - EPM e Modelo Evadan. 
Figura 2 - Taxas brutas anuais de natalidade, mortalidade e saldos migratórios na etnia Kaiabi, 1970-2000

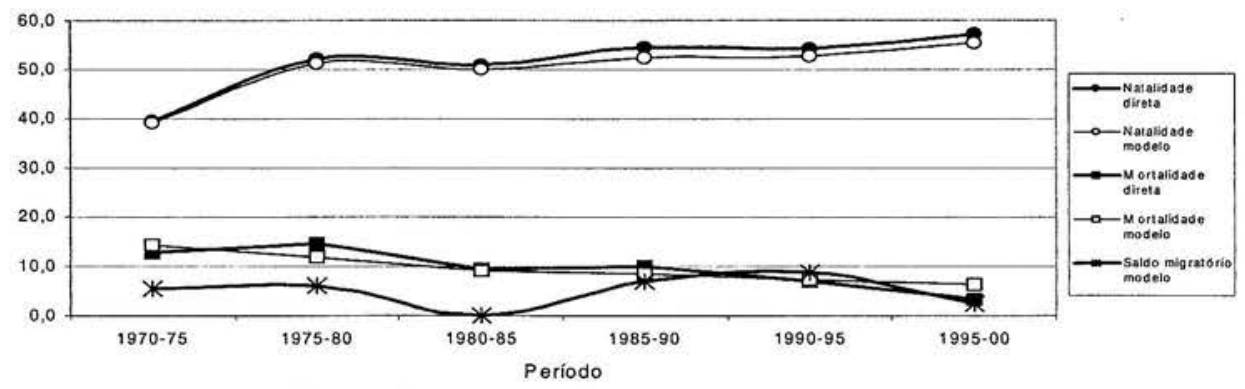

Fonte: Usma - DMP/Unifesp - EPM e Modelo Evadan

Figura 3 - Taxas de fecundidade totais na etnia Kaiabi, 1970-2000

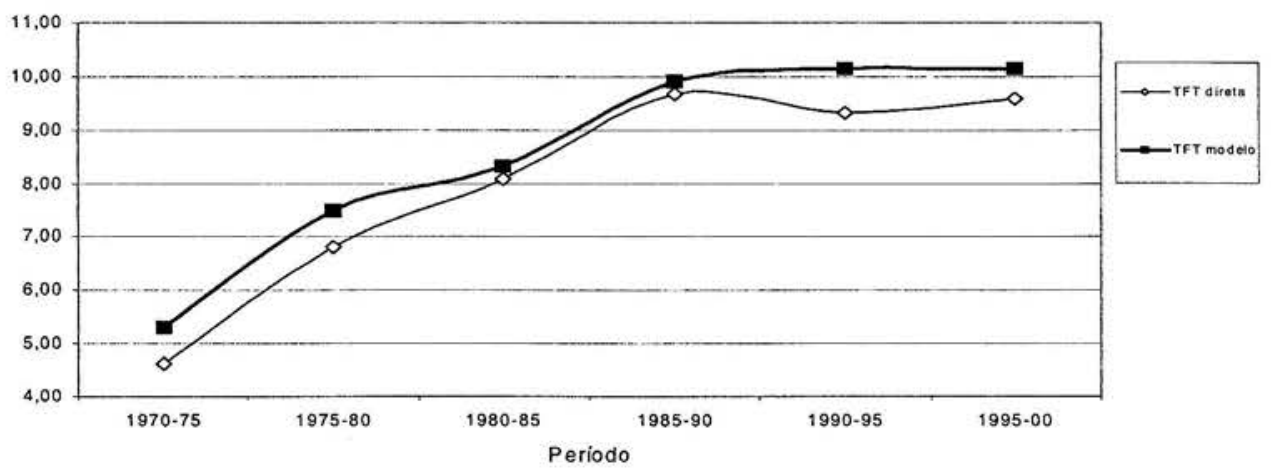

Fonte: Usma - DMP/Unifesp - EPM e Modelo Evadan

Figura 4 - Esperança de vida ao nascer na etnia Kaiabi, 1970-2000

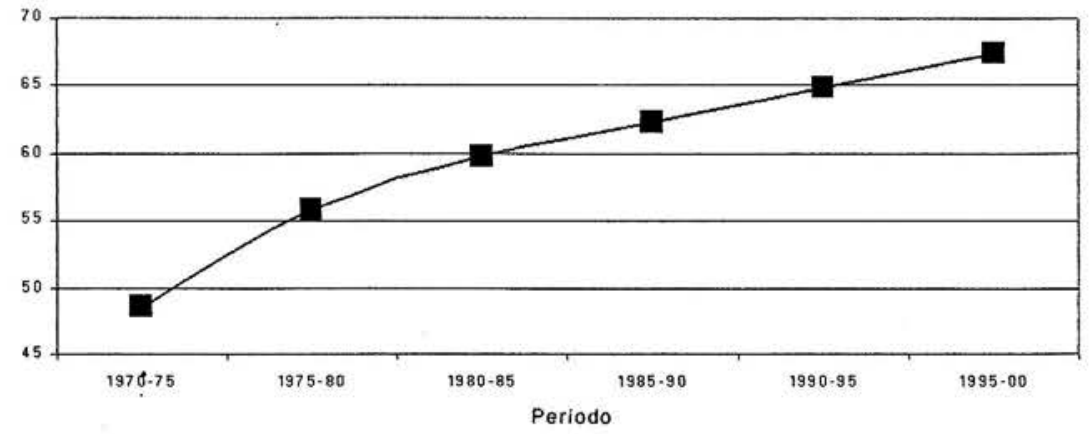

Fonte: Usma - DMP/Unifesp - EPM e. Modelo Evadan.

Mais especificamente, as taxas de fecundidade total são ligeiramente mais elevadas no modelo. A explicação talvez se encontre na estrutura populacional por sexo e idades dos Kaiabi e, particularmente a feminina, que não tem uma 
forma 'suave', apresentando bruscos aumentos, seguidos de rápidas diminuições quando são observados os grupos etários numa seqüência crescente. A estrutura das taxas de fecundidade também varia muito por causa do pequeno número de nascimentos e das oscilações da população feminina. É interessante assinalar, igualmente, que existem anos nos quais o número de meninos que nascem suplanta enormemente o de meninas e vice-versa. Estes fatores provocam taxas altamente sensíveis, no modelo, a diferentes estruturas de fecundidade. A solução encontrada aqui foi, como já se disse, a de utilizar uma estrutura média do período 19702000. De todas maneiras, a tendência mostrada pelo modelo e pelos cálculos de Pagliaro é a mesma: aumento sustentado da TFT até a década de 1990, quando chega a aproximadamente 10 filhos por mulher, um valor extremamente elevado, que se aproxima ao da fecundidade natural ou biológica (acima desse patamar existe a fecundidade das mulheres da seita protestante ortodoxa Huterite, de agricultores de origem alemã, que habitam hoje regiões do Canadá e EUA, e que gira em torno de 12 ou 13 filhos, nível considerado o limite biológico de fecundidade da espécie humana). As diferenças entre as taxas brutas de mortalidade são maiores, dado que os números envolvidos são realmente pequenos.

Tabela 2 - Taxas brutas anuais de natalidade, mortalidade, saldos migratórios e crescimento (*1.000 habitantes); cálculos diretos e através do modelo, na etnia Kaiabi, 1970-2000

\begin{tabular}{ccccccc}
\hline Período & $1970-1975$ & $1975-1980$ & $1980-1985$ & $1985-1990$ & $1990-1995$ & $1995-2000$ \\
\hline Natalidade direta & 39,3 & 52,1 & 50,9 & 54,4 & 54,2 & 57,3 \\
Natalidade modelo & 39,0 & 51,1 & 49,8 & 52,4 & 52,6 & 55,5 \\
Mortalidade direta & 12,8 & 14,6 & 9,3 & 10,0 & 6,9 & 3,5 \\
Mortalidade modelo & 14,3 & 11,8 & 9,2 & 8,5 & 7,3 & 6,3 \\
$\begin{array}{c}\text { Saldo migratório } \\
\text { modelo }\end{array}$ & 5,5 & 6,2 & 0,1 & 7,1 & 9,0 & 2,4 \\
\hline
\end{tabular}

Fonte: Usma - DMP/Unifesp - EPM e Modelo Evadan. 
Tabela 3 - Taxas de fecundidade totais e esperanças de vida ao nascer calculadas diretamente e através do modelo, na etnia Kaiabi, 1970-2000

\begin{tabular}{ccccccc}
\hline Período & $1970-1975$ & $1975-1980$ & $1980-1985$ & $1985-1990$ & $1990-1995$ & $1995-2000$ \\
\hline TFT direta & 4,62 & 6,81 & 8,07 & 9,67 & 9,33 & 9,58 \\
TFT modelo & 5,30 & 7,50 & 8,30 & 9,90 & 10,15 & 10,15 \\
Esperança de Vida & 48,54 & 55,83 & 59,70 & 62,29 & 64,88 & 67,46 \\
\hline
\end{tabular}

Fonte: Usma - DMP/Unifesp - EPM e Modelo Evadan.

Tabela 4 - Porcentagem de homens com respeito a mulheres calculadas diretamente e através do modelo, na etnia Kaiabi, 1970-2000

\begin{tabular}{cccccccc}
\hline Ano & 1970 & 1975 & 1980 & 1985 & 1990 & 1995 & 2000 \\
\hline \% homens do censo & 0,574 & 0,570 & 0,540 & 0,553 & 0,515 & 0,511 & 0,487 \\
\% homens do modelo & 0,574 & 0,559 & 0,546 & 0,535 & 0,519 & 0,506 & 0,503 \\
\hline
\end{tabular}

Fonte: Usma - DMP/Unifesp - EPM e Modelo Evadan.

\section{Discussão}

Apesar das limitações do presente exercício, o objetivo foi, em primeiro lugar, o de aplicar o modelo, na população Kaiabi, num único ano, com um único dado: o de sua população por sexo e idades em 1970. O resultado mostrou que o modelo pode 'reconstruir', de maneira aproximada, eventos vitais não disponíveis, e pode eventualmente ser aplicado às populações de pequena escala de outras etnias que não possuem registro contínuo de eventos vitais (Tabela 1 e Figura 1). 0 segundo objetivo foi o de testar a robustez do modelo apresentado, comparando os resultados obtidos por intermédio deste e daquele, derivados da técnica direta. As tabelas que comparam os resultados das taxas indiretas com as diretas mostram que tal objetivo foi alcançado (Tabela 2 e Figura 2 em diante).

Cơm exceção da análise do período anterior a 1970, no presente exercício foi adotada a estratégia de inserir no modelo, uma população exatamente igual à recenseada em 1970 e, por meio da colocação de diferentes taxas de fecundidade, mortalidade e migrações, chegar em 1975 a uma população teórica exatamente igual à recenseada, e assim por períodos qüinqüenais sucessivos até 2000. Como conseqüência, as populações do modelc são idênticas às recenseadas, variando 
apenas as taxas dos períodos qüinqüenais entre 1970 e 2000. Um interessante exercício seria tentar introduzir no modelo não a população recenseada e sim uma suavizada, com base nas médias das populações de dois anos anteriores e dois posteriores aos anos terminados em zero e cinco (1970, 75, ... 2000). Neste caso, as oscilações populacionais possivelmente diminuiriam, o que talvez tivesse resultado em taxas com tendências mais consistentes.

\section{Considerações finais}

Neste capítulo foi explicado o funcionamento do Modelo Evadan e testada a sua robustez pela comparação com os dados estimados por Pagliaro (2002), por meio de técnica direta.

Por intermédio deste exercício, verificou-se a factibilidade de sua aplicação para outras populações indígenas de pequena escala, sobre as quais existem apenas simples contagens do número de habitantes para um determinado ano ou período de tempo, sem registro de eventos demográficos, tais como mortes, nascimentos e migrações. Seu emprego seria de grande interesse social, médico, sanitário e antropológico, contribuindo para o planejamento de ações das próprias comunidades e, também, de ações governamentais.

\section{Referências Bibliográficas}

AbBagnano, N. Diccionario de Filosofía. Ciudad del México: Fondo de Cultura Econômica, 1966.

BARUZZI, R. G.; MARCOPITO, L. F. G IUNES, M. Programa Médico Preventivo da Escola Paulista de Medicina no Parque Nacional do Xingu. Revista de Antropologia, 21:155170, 1978.

CAMPANÁRIO, P. A População do Município de Guarulhos. Tendências entre 1980 e 2000 e Projeção até 2020. Guarulhos: Prefeitura Municipal, 2002.

CAMPANÁRIO, P. A estimativa da mortalidade e da fecundidade do povo Kaiabi do Parque . Indígena do Xingu, através de modelo demográfico (1970-2000). In: XIV Encontro Nacional de Estudos Populacionais (CD-ROM). Caxambu: Associação Brasileira de Estudos Populacionais, 2004.

CAMPANÁRIO, P. G BORLINA, P. Metodologia de correção e ajuste da mortalidade com tábuas modelo de vida atualizadas para o Brasil. Informe Epidemiológico do SUS, 2004. 
CAMPANÁRIO, P. G GODINHO, R. Projeção da fecundidade: Modelo relacional entre nível e estrutura. In: X ENCONTRO NACIONAL DE ESTUDOS POPULACIONAIS, Livro de Resumos p.1415-1438. Caxambu: Associação Brasileira de Estudos Populacionais - Abep, 1997.

COALE, A. J. G DEMENY, P. Regional Model Life Tables and Stable Populations. New York: Academic Press, 1985.

IBGE (INSTITUTO BRASILEIRO de GEOGRAFIA e ESTATÍsTICA). Tábuas-Modelo de Mortalidade e Populações Estáveis. Rio de Janeiro: IBGE, 1981.

PAGLIARO, H. A Revolução Demográfica dos Povos Indígenas: a experiência dos Kaiabi do Parque Indígena do Xingu, Mato Grosso (1970-1999), 2002. Tese de Doutorado, São Paulo: Faculdade de Saúde Pública, Universidade de São Paulo.

UNITED NATIONS. Model Life Tables for Under-Developed Countries. New York: United Nations, 1955. 



\section{Reflexões Acerca do Mundo Cultural e do Comportamento Reprodutivo dos Kamaiurá Ontem e Hoje}

\section{Preâmbulo}

Em 1971, Camargo e Junqueira escreveram um texto intitulado 'Análise da Fecundidade Kamaiurá' que não chegou a ser publicado na íntegra, ainda que muitos de seus resultados e discussões tenham sido recuperados no livro 'Os Índios do Ipavu' (Junqueira, 1978). Cândido Procópio Ferreira de Camargo foi sociólogo e demógrafo de grande expressão, tendo integrado o Centro de Estudos de Dinâmica Populacional da Universidade de São Paulo (Cedip) e posteriormente o Centro Brasileiro de Análise e Planejamento (Cebrap). Falecido em 1987, sua colaboração com Junqueira foi uma incursão pioneira no campo da demografia indígena no Brasil, sobretudo pela reflexão acerca das variáveis intermediárias que influenciam a fecundidade propostas por Davis e Blake.

Este capítulo encontra-se estruturado em duas partes. Na primeira está reproduzido o texto original de Camargo e Junqueira. Optou-se por mantê-lo na forma concebida à época em que foi escrito, inclusive no tocante à bibliografia utilizada. Na segunda parte, são apresentadas por Junqueira e Pagliaro breves análises com base em dados coletados em uma viagem recente (2003). Menos do que produzir uma análise detalhada, o intuito dessa revisita aos Kamaiurá foi o de fornecer um retrato recente, três décadas depois, de algumas mudanças culturais e demográficas.

\section{PARTE I}

\section{Análise da fecundidade Kamaiurá}

O inédito crescimento populacional contemporâneo ocasionou a recente expansão dos estudos demográficos. Análises de censos e estudos empíricos por amostragem multiplicaram-se nos últimos 30 anos. Ambiciosos projetos de planificação familiar procuraram afastar o espectro das previsões malthusianas. 
A atual expansão populacional, fundamentalmente devida ao crescimento demográfico dos países subdesenvolvidos, coloca de modo agudo problemas de caráter econômico, social e político.

A pressão do aumento populacional traz conseqüências políticas internas em vários países e redefine a distribuição de etnias e culturas em perspectiva internacional. Implica, igualmente, problemas econômicos, interpretados de forma catastrófica pelos economistas de orientação neo-malthusiana (Singer, 1970).

Os trabalhos de campo em demografia, as interpretações teóricas e as análises versando sobre o relacionamento entre as variáveis populacionais e as de natureza econômica e social estão geralmente baseadas em uma concepção teórica que se convencionou chamar de transição demográfica. Grande número de trabalhos científicos recorre a esta teoria de modo explícito. Constitui-se no arcabouço explicativo mais genérico para a compreensão da dinâmica das populações modernas. Mesmo quando não haja explicitação formal, os pressupostos da teoria da transição demográfica inspiram a seleção de dados e o delineamento da maioria das pesquisas demográficas contemporâneas.

Seria impróprio esboçar no presente artigo uma crítica epistemológica da teoria da transição demográfica, que apresenta, inegavelmente, algumas vantagens operacionais. Queremos apenas, ao descrever a dinâmica populacional dos Kamaiurá, especialmente seu comportamento reprodutivo, pôr em questão certos abusos de generalização, bem como mostrar a irrelevância, no caso concreto, de categorias dicotômicas do tipo tradicional versus moderno, incluídas nos fundamentos da teoria da transição demográfica.

De forma bastante sucinta, o esquema da teoria da transição demográfica descreve a passagem de altos níveis de natalidade e de mortalidade, para níveis baixos e controlados, num período transitório em que o declínio da mortalidade antecede o da natalidade, gerando rápido crescimento populacional nas sociedades pré-industriais quando se industrializam (Coale $G$ Hoover, 1958).

A ampla utilização, por vezes implícita, da teoria da transição demográfica, com a finalidade de descrever e interpretar tendências populacionais contemporâneas, tem envolvido generalizações nem sempre consubstanciadas em fatos. O exemplo da pequena população Kamaiurá é bastante ilustrativo (sobretudo se o comparamos com os padrões predominantes de fecundidade nas populações caboclas circunvizinhas).

Visando a facilitar o confronto entre a perspectiva teórica da teoria da transição demográfica e os fatos populacionais observados no grupo Kamaiurá, assume-se a proposta de ressaltar alguns aspectos particularmente contrastantes. Neste sentido, pode-se dizer que a teoria da transição demográfica supõe que: $1^{\circ}$ ) os povos pré-industriais têm alta fecundidade, que é regulada somente por normas sociais que afetam - de modo não intencional - as chamadas variáveis intermediárias 
de Davis e Blake (Freedman, 1963); $2^{\circ}$ ) os povos pré-industriais não definem de maneira expressa e intencional o número de filhos desejados, tendendo a perceber como uma fatalidade o tamanho normalmente alcançado por suas famílias; $3^{\circ}$ ) as culturas dos povos pré-industriais não explicitam valores racionais, colocados como fins ou como meios, na justificativa do número de filhos considerados ideais (tamanho ideal da família).

\section{O grupo estudado}

Na região dos formadores do rio Xingu vivem os índios Kamaiurá, de filiação lingüística Tupi, em profunda interação com outros grupos tribais, mas resguardados de contato regular com a sociedade brasileira. Os fatores que mais favoreceram tal isolamento parecem ter sido as barreiras naturais que circundam a região, a presença de tribos indígenas agressivas e o relativo desinteresse econômico da sociedade nacional por aquelas terras. Embora, no momento, os elementos que garantem o isolamento estejam ameaçados de perto tanto pela abertura de rodovias, como pela 'neutralização' de tribos hostis e pelo vivo interesse por terras indígenas, vivem ainda os Kamaiurá como um grupo que se distingue da chamada 'civilização ocidental'.

A história de seu contato com representantes dessa civilização remonta a 1884, com a expedição de Karl von den Steinen. Daí por diante, várias expedições penetraram na região e estabeleceram contatos intermitentes e de curta duração com o índio alto-xinguano.

Um canal de contato mais regular, se bem que indireto, estabeleceu-se ainda em 1884, com a aproximação dos índios Bakairi, dos rios Novo e Paranatinga, aos do rio Batovi. Esse encontro, que mais tarde provocou o deslocamento dos Bakairi dos formadores do Xingu para o Paranatinga, propiciou a entrada de objetos da civilização, bem como de doenças na região. Porém, somente na década de 1940 é que os alto-xinguanos estabeleceriam contato mais estreito com a sociedade nacional.

Em 1942, com a criação do órgão federal Fundação Brasil Central, iniciase a abertura de estradas e o estabelecimento de acampamentos na área. A coluna de homens responsáveis por essa penetração, cognominada Expedição RoncadorXingu, alcanç̧a em 1946, a zona dos formadores do Xingu e funda, num de seus tributários, o ribeirão Jacaré, um posto com o mesmo nome. Permanecem nesse posto e noutro - Diawarum - localizado mais ao norte, os irmãos Villas Bôas, procurando proteger os índios de maneira mais efetiva. Os resultados das experiências do Serviço de Proteção aos Índios, em algumas dezenas de anos de atividade indigenista, mostravam claramente que não bastava a instalação 
de postos assistenciais para garantir a sobrevivência do índio. O processo de expansão da sociedade brasileira e o avanço violento de suas frentes pioneiras, quando não exterminavam sumariamente o índio, colocavam-no frente a uma situação de contato a cujo impacto não podia resistir por carência de recursos biológicos e culturais.

A primeira etapa da tarefa, a ser realizada pelos irmãos Villas Bôas, era garantir ao alto-xinguano, de maneira efetiva, a posse da terra, não permitindo que o território sofresse redução capaz de colocar em perigo o funcionamento de sua economia tradicional. E não há dúvida de que se não fossem adotadas medidas severas a esse respeito, de pouco valeria a instalação de postos na região. Prova disso foi dada poucos anos após a penetração da Expedição Roncador-Xingu, na área que, apesar de economicamente marginal, ganhou destaque no cenário brasileiro. Não tardou que a nova região desbravada viesse a ser alvo de interesses imobiliários. Sob as vistas da Fundação Brasil Central, a terra passou a ser retalhada e vendida a particulares. Somente a reação enérgica dos líderes da extinta expedição e do Serviço de Proteção aos Índios conseguiu sustar a comercialização das terras indígenas. Finalmente, em 1961, é que se logrou alcançar uma proteção mais definitiva desse território, com a criação do Parque Nacional do Xingu.

Contando com uma área de $22.000 \mathrm{~km}^{2}$, o Parque Nacional do Xingu objetiva assegurar a sobrevivência dos grupos indígenas da área e preservar os recursos de flora e fauna que constituíam reservas destinadas a estudos científicos.

Em linhas gerais, duas preocupações básicas orientam hoje, como na época de sua fundação, as atividades do Parque. De um lado, procura ele garantir a sobrevivência das populações indígenas mediante a adoção de medidas médicopreventivas e curativas. Nesse sentido, interfere, de forma planejada, inclusive na esfera nativa de produção de alimentos, visando ao enriquecimento da dieta tradicional. Exerce ainda controle sobre os contatos entre índios e civilizados, tendo em mira impedir a entrada de doenças contagiosas nas aldeias. A longo prazo, empenha-se em preparar o índio para que se mantenha autônomo como povo, quando, num futuro não determinado, entrar em contato mais direto com a sociedade brasileira. Inovações são, para esse fim, introduzidas lentamente ao mesmo tempo em que se procura preservar a coesão social de cada um dos grupos nativos.

Dentro dessa linha de pensamento, o Parque estimula a realização das principais cerimônias nativas e prestigia os líderes das aldeias que detêm controle efetivo sobre o comportamento dos índios. Os dirigentes do Parque, concomitantemente ao encaminhamento das atividades em direção aos objetivos previamente estabelecidos, estão também conscientes do perigo que uma mudança provocada pode acarretar, vale dizer, a desorganização e a perda da identidade cultural dos grupos. 
A realização dessas tarefas exige por parte dos dirigentes do Parque um controle muito grande de todas as situações que envolvam não só a introdução de novos artigos na área, mas também das relações entre civilizados e índios. O sucesso desse tipo novo de empreendimento reside na identificação e intervenção rápidas de todo processo que possa vir a desencadear mudanças desorganizatórias nas aldeias. Quanto menores as interferências na vida do índio que escapam ao controle do Parque, maiores serão as garantias da obtenção dos resultados objetivados.

Os contatos entre índios e civilizados ocorrem dentro do próprio Parque, uma vez que este existe como verdadeira 'reserva' onde é controlada a entrada e a saída das pessoas. Ainda que seja difícil um total controle sobre o comportamento dos índios, e possam ocorrer saídas irregulares, que aliás são raras, o isolamento da região desestimula as transgressões. Ao lado disso, o Parque, como único fornecedor regular de bens vindos da 'civilização', está em condições de persuadir o índio a permanecer dentro de seus limites geográficos.

Dentro do Parque, o índio tem contatos ocasionais com visitantes ou pesquisadores e contatos mais freqüentes com o pessoal da Base Aérea da Força Aérea Brasileira, localizada dentro dos limites do Parque. Por força dessa situação de contato controlado, a cultura dos grupos tribais da região, e entre eles a dos Kamaiurá, mantém-se relativamente inalterada, operando com determinantes basicamente tradicionais e, portanto, tribais.

Os dados apresentados aqui foram retirados de pesquisa mais ampla realizada na área, desde 1968. Nessa pesquisa procurou-se explicar e analisar o projeto de vida Kamaiurá. Numa análise preliminar do material, defrontou-se com elementos que mostravam ser diferente o comportamento fértil do grupo em relação ao comportamento de outras comunidades tribais do Brasil e de grupos vizinhos civilizados, constituídos em sua maioria por frente cabocla. E mais ainda, seu comportamento fértil exibia alguns pontos de contato com o das sociedades modernas industrializadas. $\mathrm{O}$ fato mereceu grande atenção por ser o comportamento fértil Kamaiurá derivado de elaboração cultural interna e não influência da sociedade brasileira.

\section{Dados demográficos}

Os dados de natureza demográfica foram coligidos na aldeia Kamaiurá mediante entrevistas, obtendo-se informações relativas ao número e à composição por sexo e idade da população. A especificação da idade foi aproximada, não havendo meios seguros para determinar com precisão o ano de nascimento dos indivíduos, especialmente dos de mais de 30 anos. Optou-se pela inclusão dos indivíduos em faixas de idade a fim de minimizar as possibilidades de erro. 
As pirâmides de idade apresentadas nas Figuras 1 e 2 revelam as drásticas alterações da situação de vida da população em 1949 em comparação com sua situação em 1971, ocasião da pesquisa de campo. A Figura 1, de Galvão (1949), revela uma composição populacional caracterizada por pequena porcentagem de pessoas com menos de 14 anos em razão dos altos índices de mortalidade infantil e de mortalidade de jovens, refletindo a fase final de um longo e doloroso processo de depopulação. Iniciando-se em 1946 uma política mais racional e humana, sob a liderança dos irmãos Villas Bôas, em relação a vários grupos indígenas na região do Xingu, inclusive os Kamaiurá, verifica-se o crescimento populacional e a natural ampliação das faixas etárias mais jovens na população. Nota-se, também, os efeitos, sobre a população de 15 a 29 anos, de uma epidemia de sarampo que acometeu cerca de 600 índios do Alto Xingu, em 1954, matando 15 kamaiurá (Motta, 1954).

Figura 1 - Pirâmide etária dos Kamaiurá, 1949

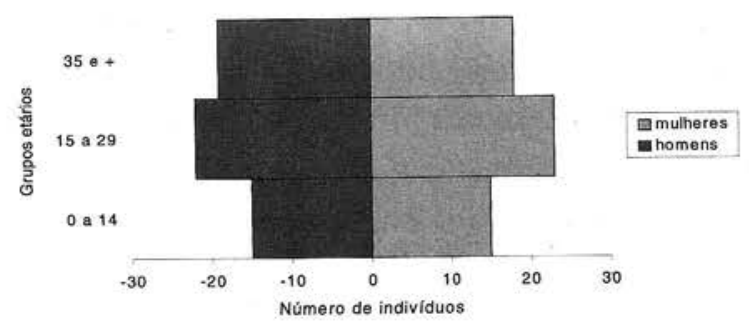

Figura 2 - Pirâmide etária dos Kamaiurá, 1971

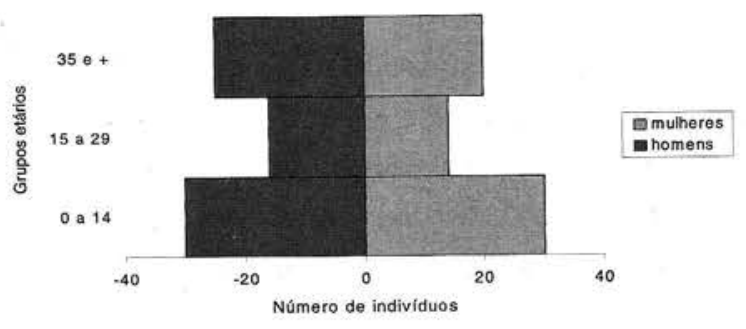

A comparação dessas pirâmides evidencia mudanças acentuadas nas condiçōes de vida do grupo nos últimos vinte anos. Realmente, o Parque Nacional do Xingu veio criar condições que impediram o impacto mais agressivo da sociedade brasileira. Persistindo muitos dos valores da cultura grupal, desenvolveu-se também o crescimento da população em virtude da adoção de medidas sanitárias que vieram a reduzir consideravelmente a mortalidade infantil.

A Tabela 1 apresenta o número de mulheres não-solteiras da aldeia e a média de filhos tidos, vivos e mortos até 1971. A média de filhos vivos por mulher, em grande maioria ainda em período reprodutivo, é de 2,4. Considerando-se todos 
os nascimentos vivos, a média é de 3,7 filhos por mulher, tendo a fecundidade acumulada até o final do período reprodutivo variado entre 3,5 e 7 filhos para as seis mulheres com 40 anos ou mais. A média de filhos mortos de todas as mulheres é de 1,3 e a das mulheres de 40 ou mais anos variou entre 1,5 e 4 filhos.

Esses dados revelam um padrão de fecundidade certamente muito inferior às possibilidades biológicas de reprodução do grupo Kamaiurá. Evidentemente, os baixos níveis de fecundidade, inferiores aos das populações caboclas brasileiras, indicam a presença de normas sociais que afetam as chamadas variáveis intermediárias de Davis e Blake, que influenciam a fecundidade (Freedman, 1963).

Tabela 1 - Mulheres kamaiurá maiores de 15 anos de idade e médias de filhos tidos, vivos e mortos, até 1971

\begin{tabular}{ccccc}
\hline $\begin{array}{c}\text { Grupos de idades } \\
\text { aproximadas }\end{array}$ & Mulheres não-solteiras & Média de filhos vivos & Média de filhos mortos & Média de filhos tidos* \\
\hline 15 a 19 & 1 & - & - & - \\
20 a 24 & 5 & 1,8 & 0,2 & 2,0 \\
25 a 29 & 5 & 1,8 & 0,6 & 2,4 \\
30 a 34 & 3 & 3,7 & 1,0 & 4,7 \\
35 a 39 & 9 & 3,2 & 1,7 & 4,9 \\
40 a 44 & 1 & 3,0 & 4,0 & 7,0 \\
45 a 49 & 2 & 2,0 & 1,5 & 3,5 \\
50 a 54 & 3 & 1,7 & 3,0 & 4,7 \\
\hline Total & 29 & 2,4 & 1,3 & 3,7 \\
\hline
\end{tabular}

*Excluídos os sacrificados por infanticídio.

Fonte: Pesquisa de campo, 1971.

As variáveis intermediárias são aquelas que afetam diretamente a fecundidade de uma população. As normas e valores sociais afetam a fecundidade necessariamente, por meio da atuação das variáveis intermediárias. Davis e Blake classificaram os seguintes fatores como constitutivos das variáveis intermediárias: fatores relativos à formação e à dissolução de uniões; fatores relativos à relação sexual na união; fatores relativos à exposição à concepção; fatores relativos à gestação e ao parto.

Não é particularmente significativo no estudo do comportamento reprodutivo da população Kamaiurá apenas a análise de normas e valores que afetam as variáveis intermediárias e determinam de maneira não intencional um certo padrão de fecundidade. Mais relevante é a existência de valores precisos quanto ao número ideal de filhos e a disposição - com os recursos técnicos disponíveis de limitar a prole ao número desejado. 
Para fins da presente análise, faz-se a distinção entre as normas e valores que afetam a fecundidade de modo não intencional e os valores conscientes sobre o tamanho da família e o número ideal de filhos.

\section{Normas e valores que afetam de modo não intencional a fecundidade}

\section{Fatores relativos à formação da união}

Há na cultura Kamaiurá uma expectativa generalizada de que todas as pessoas devem se casar. O casamento, além das funções de procriação e as de natureza sexual, torna-se igualmente necessário por razões econômicas, decorrentes da divisão social do trabalho. Salvo uma jovem recém-saída da reclusão e uma separada, em 1971 não havia nenhuma mulher, em idade fértil, não casada na aldeia.

O casamento se efetua, para as mulheres, logo após o início de seu período reprodutivo, e o tempo de reclusão após a primeira menstruação prolonga-se até o máximo de um ano. Cessando a reclusão, ocorrem imediatamente os casamentos, em geral anteriormente combinados.

A ruptura da união, conseqüente da separação do casal, não impede a contratação imediata de um novo casamento. A morte de um cônjuge, entretanto, obriga o sobrevivente a um período considerado de 'luto', cuja duração é variada, em que não pode se casar novamente.

De modo geral, pode-se considerar que as normas relativas à formação da união tenderiam a favorecer uma alta fecundidade, quer pelo início precoce do matrimônio, quer pela facilidade na contratação de novo casamento. Em relação às normas de casamento há de se ter em conta também a liberdade de relações extraconjugais, que representa uma modalidade restrita, mas relativamente difundida de relacionamento sexual. Normalmente, formam-se casais de namorados, parceiros temporariamente estáveis, cujo grau de legitimação é muito inferior ao do casamento. Esse tipo de união é muito menos fecunda do que o casamento formal, como se verá a seguir.

\section{Fatores relativos à relação sexual}

Existem restrições que limitam as relações sexuais em certas ocasiões: quanto aos homens, ocorrem restrições ao relacionamento sexual dos pajés durante seu período de iniciação e dos lutadores durante o período das competições festivas; no tocante às mulheres, prevê-se um período de abstinência sexual que, idealmente, deveria perdurar durante um ano após o parto; interessante observar que a cultura 
Kamaiurá não considera a relação sexual como uma obrigação estrita ligada aos papéis de mulher casada. Supõe-se a anuência voluntária da mulher, não havendo expectativa de formas de constrangimento que a obriguem a uma relação momentaneamente não desejada.

\section{Fatores que afetam a concepção}

Como as crianças são amamentadas por período variado de tempo, no entanto, geralmente bastante longo, chegando até três anos, a fecundabilidade das mulheres diminui consideravelmente nesse espaço de tempo.

\section{Normas e valores que afetam de modo intencional a fecundidade}

Habitualmente as decisões relativas às conseqüências reprodutivas do ato sexual e à continuidade das gestações decorrem de intenções conscientes a respeito do tamanho da família e do desejo de ter ou não um filho. Os Kamaiurá afirmam ter o conhecimento de ervas capazes de evitar a concepção e que seriam propriamente anticoncepcionais. As análises farmacológicas realizadas até o momento não foram suficientes para comprovar a veracidade dessa alegação.

Observa-se que acreditam igualmente na propriedade que têm algumas ervas de facilitar a fecundação.

Quanto às variáveis relativas ao desenvolvimento da gestação, afirmam os Kamaiurá possuir remédios capazes de provocar o abortamento. Quer por intermédio de processos mecânicos, quer por meio de ervas, cuja eficácia farmacológica não é controlada, as mulheres praticam efetivamente o abortamento.

Em algumas situações sociais a cultura Kamaiurá legitima o abortamento. Usualmente, o status da mulher constitui o fundamento para a decisão de abortar. As mulheres sem marido ou cujo marido tenha estado ausente por um período longo de tempo recorrem a práticas abortivas. O padrão de liberdade sexual extraconjugal pode ocasionar concepção indesejável, que é igualmente interrompida.

Observe-se que o infanticídio como forma eticamente aceita de impedir a sobrevivêncịa do recém-nascido justifica-se no caso do nascimento de gêmeos, de crianças defeituosas e, eventualmente, nas situações de status análogas às que levam ao abortamento provocado. Importante considerar que as práticas abortivas são também utilizadas como uma maneira deliberada de planejar o tamanho da família e evitar um nascimento indesejado. 
A Tabela 2 revela o número ideal de filhos por sexo e idade dos entrevistados. As perguntas formuladas foram: "Quantos filhos é bonito ter?" e "Quantos filhos gostaria de ter?", ou indagações semelhantes que visavam esclarecer ao entrevistado o sentido da questão.

Inicialmente, a pesquisa permitiu verificar que a idéia de um tamanho 'bonito' e conveniente de família não era estranha ao universo cultural do grupo estudado. $\mathrm{O}$ tamanho ideal apresentado estava longe das potencialidades biológicas e indicava uma dimensão não muito grande de família.

Entre as gerações, as diferenças relativas ao tamanho ideal de família seriam devidas, provavelmente, à acentuada diminuição da mortalidade infantil e da mortalidade entre os jovens, levando as mulheres das gerações que iniciam seu período reprodutivo a redefinirem o número desejado de filhos de modo a manterem a mesma família relativamente pequena da tradição Kamaiurá.

Tabela 2 - Número de mulheres e homens entrevistados, médias de filhos vivos, mortos e idealizados

\begin{tabular}{|c|c|c|c|c|c|c|c|c|}
\hline $\begin{array}{l}\text { Grupos de } \\
\text { idades } \\
\text { aproximadas }\end{array}$ & $\begin{array}{c}\text { N. de } \\
\text { mulheres } \\
\text { entrevistadas }\end{array}$ & $\begin{array}{l}\text { Média de } \\
\text { filhos vivos }\end{array}$ & $\begin{array}{l}\text { Média de filhos } \\
\text { mortos }\end{array}$ & $\begin{array}{l}\text { Média de } \\
\text { filhos } \\
\text { idealizados }\end{array}$ & $\begin{array}{l}\text { N. de homens } \\
\text { entrevistados }\end{array}$ & $\begin{array}{l}\text { Média de } \\
\text { filhos vivos }\end{array}$ & $\begin{array}{l}\text { Média de } \\
\text { filhos mortos }\end{array}$ & $\begin{array}{l}\text { Média de } \\
\text { filhos } \\
\text { idealizados }\end{array}$ \\
\hline 15 a 19 & 2 & - & - & 2,0 & - & - & - & - \\
\hline 25 a 29 & 2 & 2,5 & 1,0 & 2,8 & 1 & 2.0 & - & 2,5 \\
\hline 30 a 34 & 1 & 6.0 & 1.0 & 10,0 & 2 & 2,0 & 1.0 & 3,3 \\
\hline 35 a 39 & 4 & 2,5 & 1,0 & 6.4 & 1 & 2.0 & 2.0 & 2,0 \\
\hline 45 a 49 & - & - & - & - & 1 & 4,0 & 2.0 & 7,5 \\
\hline 50 a 54 & 3 & 1,7 & 3,0 & 5,3 & - & - & - & - \\
\hline Total & 12 & 2,2 & 1.3 & 5.1 & 5 & 2.4 & 1,0 & 3.7 \\
\hline
\end{tabular}

Fonte: Pesquisa de campo, 1971.

A Tabela 3, construída por Ribeiro (1970) com dados de 1954, mostra para os Kuikuro, população culturalmente análoga à Kamaiurá, índices de fecundidade semelhantes aos das gerações mais velhas do grupo estudado. A diferença evidente entre esta Tabela e a Tabela 2 diz respeito aos níveis de mortalidade. A taxa de mortalidade Kamaiurá decresceu rapidamente nas últimas duas décadas. Presume-se que provavelmente esta alteração da dinâmica populacional veio ocasionar uma diminuição no número de filhos necessários para conseguir na sociedade Kamaiurá o mesmo padrão de família que é funcional ao seu modo de produção e à sua cultura. 
Tabela 3 - Número de mulheres, partos, nascimentos vivos, filhos mortos e sobreviventes

\begin{tabular}{ccccc}
\hline Partos & Mães & Nascimentos & Mortes & Sobreviventes \\
\hline 1 & 6 & 6 & 2 & 4 \\
2 & 2 & 4 & 2 & 2 \\
3 & 5 & 15 & 7 & 8 \\
4 & 3 & 12 & 5 & 7 \\
5 & 4 & 20 & 12 & 8 \\
6 & 1 & 6 & 5 & 1 \\
7 & 4 & 28 & 20 & 8 \\
8 & - & - & - & - \\
9 & 2 & 18 & 10 & 8 \\
\hline Totais & 27 & 109 & 63 & 46 \\
\hline
\end{tabular}

Fonte: Ribeiro, 1970.

$\mathrm{Na}$ interpretação do tamanho ideal de família, convém observar que as respostas fornecidas pelos informantes parecem indicar níveis diferentes de concreção.

O nível mais genérico e afastado da situação pessoal do entrevistado é aquele no qual se considerava bom e conveniente um número relativamente grande de filhos (entre 5 e 10); o outro, mais específico, é o nível que implicava a definição de intenções pessoais do entrevistado, no qual o número de filhos desejado girava entre 2 e 4.

O aspecto particularmente significativo da dinâmica populacional Kamaiurá é concernente ao nível de plena racionalidade com que se entende o processo reprodutivo. Esta racionalidade, que a teoria da transição demográfica supõe emergir após um processo histórico determinado, encontra-se realizada sem outras interferências culturais na tradição Kamaiurá.

A análise das motivações acerca do tamanho da família e dos motivos que justificariam sua ampliação ou diminuição, deixa transparecer um estilo de controle racional que nos surpreende por sua 'modernidade'. Assim, o desejável aumento da família liga-se, especialmente em relação aos homens com funções de liderança, à idéia de que a expansão demográfica Kamaiurá é condição de sobrevivência do grupo e de realização mais completa de suas aspirações culturais. A família grande é igualmente justificada em termos dos papéis de proteção e segurança que os filhos poderiam representar em relação aos pais. 
Por outro lado, racionalidade paralela encontra-se nas justificativas referentes a um ideal de família bastante reduzida. "Os filhos gastam muita comida" e "dão muito trabalho" constituem o centro da argumentação de natureza econômica que fundamenta, aos olhos da cultura Kamaiurá, a opção por uma família pequena.

Encontramo-nos, pois, perante uma atitude racional e 'moderna' que escapa inteiramente ao evolver histórico previsto na teoria da transição demográfica. Na visão Kamaiurá da família não ocorre uma concepção fatalista ou a inércia do peso de uma tradição estática, mas um projeto perfeitamente consciente de que o tamanho da família constitui uma esfera de decisão livre e racional. Nem a frente cabocla brasileira, nem os contatos ocorridos no Parque explicariam as atitudes e valores dos Kamaiurá sobre o comportamento reprodutivo. Seria interessante comparar as concepções dos setores rurais brasileiros, determinadas por suas funções na divisão social do trabalho da nação com a visão do mundo Kamaiurá, muito mais livre, e que define seus objetivos tomando por base uma visão globalizante de seus próprios interesses e do patrimônio cultural que lhe cabe usufruir e preservar.

PARTE II

\section{Revisitando os Kamaiurá}

Cerca de trinta anos depois da pesquisa de Candido Procópio Ferreira de Camargo e Carmen Junqueira, que serviu de base para o artigo 'Análise da fecundidade Kamaiurá', revisitou-se a aldeia de Ipavu a fim de estudar as mudanças ocorridas na relação que os índios mantinham com o modo de vida tradicional e avaliar alguns aspectos do seu padrão reprodutivo. Partiu-se do pressuposto de que nessas três décadas deveria ter ocorrido a reelaboração de aspectos da sua tradição, que permitisse melhor enfrentar as novas condições criadas pela expansão da agropecuária no Centro-Oeste brasileiro, inclusive o surgimento de cidades nas adjacências do Parque Indígena do Xingu.

As informações que aqui são apresentadas resultaram da viagem realizada à área, entre os dias 8 e 21 de julho de 2003. O tempo relativamente curto da observação de campo permitiu o registro e a análise preliminar de inovações introduzidas na vida da aldeia e o levantamento de algumas informações demográficas, completadas com dados do arquivo do programa de saúde da Universidade Federal de São Paulo (Unifesp), permitindo traçar em linhas gerais o sentido de alguns processos em curso. 
Do ponto de vista cultural, embora o ritmo de vida pouco tenha se alterado, inovações recentes foram incorporadas ao dia-a-dia da aldeia. É o caso, por exemplo, do conjunto de poço, caixa d'água e bomba movida a energia solar, que leva água a torneiras instaladas no fundo das casas, facilitando tarefas domésticas e melhorando as condições de saúde de modo geral. O uso regular de caminhão, trator, gerador, motores de popa, aparelhos de televisão e rádio transmissor acarretou maior mobilidade, redução do tempo de trabalho e maior familiaridade com a vida urbana, seja pelas viagens mais constantes até cidades vizinhas, seja pelas imagens fornecidas pela televisão. A manutenção desses equipamentos é um dos desafios que os Kamaiurá enfrentam, pois a necessidade de moeda ganhou espaço. Sabem que sem dinheiro não é possível comprar gasolina, pagar o conserto dos motores e adquirir uma série de outros artigos que já fazem parte do rol das novas necessidades.

Quem garante o pagamento das despesas da comunidade é a Associação Mavutsinin, cujos recursos vêm principalmente da venda de artesanato e doações eventuais. Mas os propósitos da Associação são bem mais amplos, estendendo-se à elaboração e execução de projetos na área social e cultural. Na época da pesquisa, a Associação coordenava e executava três projetos, dentre eles o da Escola Mawaiaka.

Os objetivos da escola são: preservar e resgatar a cultura Kamaiurá e capacitar jovens e crianças no uso dos conhecimentos não índios. Deve-se aos velhos a idéia de criar uma escola que atendesse diretamente aos interesses dos índios. Os alunos têm aulas de mitologia Kamaiurá, luta huka huka, música tradicional, pintura corporal, artesanato e língua Kamaiurá (escrita e leitura). Mesmo as disciplinas básicas do Ensino Fundamental - português, matemática, geografia e história - são introduzidas de modo diferenciado, apoiadas no conhecimento dos velhos e nas atividades cotidianas. Desse modo, a geografia parte da descrição e classificação dos espaços indígenas; a história, dos deslocamentos da aldeia no decorrer dos tempos; o ensino do português volta-se, num primeiro momento, à compreensão da língua falada; e a matemática, à habilidade de contar e usar dinheiro. O projeto acumula resultados positivos na dinamização de conteúdos culturais previstos na programação curricular. Aumentou também a compreensão da língua portuguesa, e vários jovens já estão alfabetizados. O desafio agora é progredir nạ leitura e escrita Kamaiurá, que vêm sendo retomadas após terem sido definidas as regras para a escrita.

De modo geral, a continuidade cultural que as gerações mais velhas querem assegurar acaba sendo mantida ao longo de sucessivas metamorfoses e agregações. Ilustra bem essa afirmação o que se observou e registrou no diário de campo: 
Olhando a aldeia como um todo as coisas parecem embaralhadas, principalmente a partir do entardecer quando diferentes comportamentos se cruzam: alguns jovens estacionam suas bicicletas em frente à casa das flautas e trajando tênis e bermudões conversam animadamente; no pátio central garotos e rapazes jogam animados uma partida de futebol; atrás da casa das flautas, um outro time formado por moças disputa uma outra partida. Em algumas tardes é possível ainda ver um time mirim de meninos e meninas nos espaços que restam. Quando a noite chega, é a vez do grupo de crianças se reunir no pátio para ensaiar cantigas tradicionais que aprendem na escola, enquanto uns poucos meninos treinam a luta huka huka. Quando tudo escurece, pode ter início numa das casas uma sessão de vídeo de uma festa do kuarup, exibido quase todas as noites e, em seguida, ouve-se um $C D$ com músicas cerimoniais Kamaiurá e cantos em língua Jê. $O$ som se propaga pelas casas vizinhas e se mistura com as melodias de Kelly Key, Rouge e conjuntos americanos modernos, rodadas num conjunto de som poderoso. Se algum aparelho de televisão estiver funcionando, chega a hora da novela. No dia seguinte, um conjunto de flautas uruá vai de casa em casa, enchendo a aldeia da atmosfera de outros tempos. Tudo parece indicar que novidades modernas chegam e se acomodam ao lado dos costumes antigos, como se sempre tivesse sido assim.

Do ponto de vista demográfico, observou-se um vigoroso aumento populacional nesses 32 anos. Em 1971, a população total kamaiurá era de 131 habitantes (Junqueira, 1978). Em 2003, viviam em duas aldeias, em razão de uma cisão do grupo em meados da década de 80 , perfazendo um total de 378 indivíduos. Nesse período, o crescimento médio anual da população foi de $3 \%$ ao ano, e estaria acompanhando a tendência observada em outras populações indígenas do PIX, como os Waurá, também moradores do Alto Xingu, que cresceram 4,8\% entre 1970 e 1999.

As pirâmides etárias de 1971 e 2003, apresentadas em números absolutos, nas Figuras 3 e 4, demonstram significativas mudanças na estrutura populacional, sendo notória a aquisição de uma maior regularidade no contorno da pirâmide de 2003, a ampliação do número de crianças, jovens e indivíduos maiores de 55 anos, indicando aumento da sobrevivência da população em geral.

A Tabela 4 mostra o número de mulheres não solteiras, com idades entre 15 e 54 anos, seus filhos vivos e mortos em 2003 e indicadores da fecundidade acumulada dessas mulheres. Mudanças no tamanho de família podem ser observadas mediante tais dados, tendo o número médio de filhos vivos das mulheres não solteiras aumentado de 2,4 para 4,0. Considerando-se os filhos tidos, não computados os sacrificados por infanticídio, a média de filhos por mulher variou de 3,7 para 4,3, tendo a média de filhos mortos diminuído de 1,3 para 0,3 por mulher. 
Figura 3 - Pirâmide etária dos Kamaiurá, em grupos qüinqüenais de idade, 1971

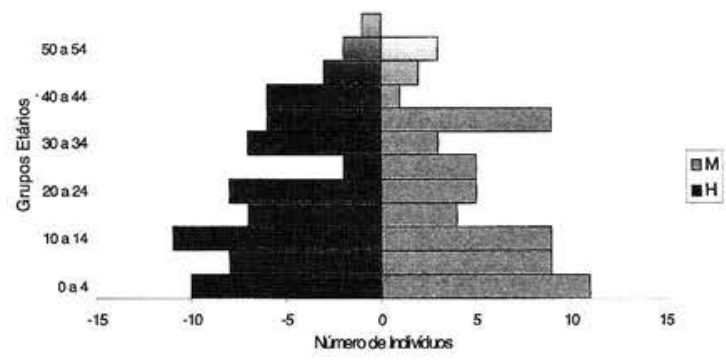

Figura 4 - Pirâmide etária dos Kamaiurá, em grupos qüinqüenais de idade, 2003

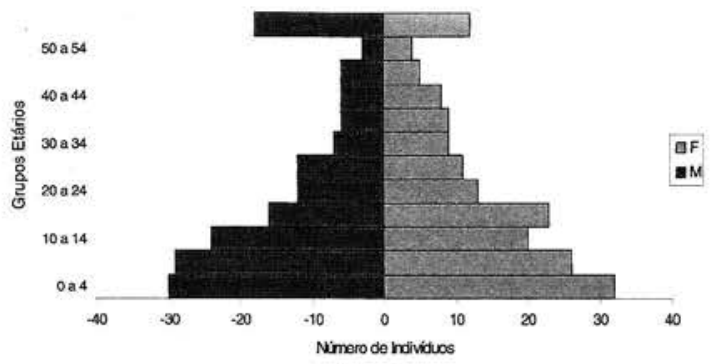

Tabela 4 - Indicadores de fecundidade acumulada das mulheres Kamaiurá, em 1971 e 2003

\begin{tabular}{cccccccc}
\hline Anos & $\begin{array}{c}\text { N. de mulheres } \\
\text { năo-solteiras de } \\
15 \text { a } 54 \text { anos }\end{array}$ & $\begin{array}{c}\text { N. de filhos } \\
\text { tidos* }^{*}\end{array}$ & $\begin{array}{c}\text { N. de filhos } \\
\text { sobreviventes }\end{array}$ & $\begin{array}{c}\text { N. de filhos } \\
\text { mortos }\end{array}$ & $\begin{array}{c}\text { Média de filhos } \\
\text { tidos* }\end{array}$ & $\begin{array}{c}\text { Média de filhos } \\
\text { sobreviventes }\end{array}$ & $\begin{array}{c}\text { Média de filhos } \\
\text { mortos }\end{array}$ \\
\hline 1971 & 29 & 108 & 70 & 38 & 3,7 & 2,4 & 1,3 \\
2003 & 65 & 284 & 263 & 21 & 4,3 & 4,0 & 0.3 \\
\hline
\end{tabular}

*exceto os sacrificados por infanticídio.

Fontes: Pesquisas de campo, 1971 e 2003 e arquivos da Usma/Unifesp/EPM.

O inquérito realizado em 1971 já apontava para a intenção dos Kamaiurá em ampliar o tamanho de suas famílias, expressa no número de filhos desejado das pessoas-entrevistadas, de 3,7 e 5,1 filhos, em média, para homens e mulheres, respectivamente. $\mathrm{O}$ aumento da média de filhos por mulher, resultante dessa redefinição intencional do tamanho ideal de família, estaria contribuindo para a expansão das novas gerações. Além disso, o novo padrão de família estaria refletindo, também, a melhoria das condições de saúde e o conseqüente aumento da sobrevivência da população, decorrente das ações médico-sanitárias levadas a efeito nos últimos 35 anos, o que teria garantido a sobrevivência de recém-nascidos e de crianças na primeira infância. 
Essa constatação remete à discussão sobre a complexa relação entre padrões socioculturais e demográficos das sociedades indígenas, que entre os Kamaiurá configura-se claramente na intenção de expandir seu volume populacional e ampliar seu destaque no cenário político do Alto Xingu.

As mudanças culturais e demográficas registradas sugerem que os Kamaiurá se preparam para escolher novos caminhos, resguardando as imagens do passado, mas estabelecendo ligações fortes com o presente e reformulando alguns padrões tradicionais. Sabe-se que a cultura de um povo pode ter larga permanência desde que não perca sua plasticidade e capacidade de orientar o diálogo com os novos tempos e disso extrair um sentido.

Agradecimentos

Aos Kamaiurá pela colaboração com este trabalho.

A pesquisa realizada na aldeia do Ipavu, em 2003, é parte integrante do projeto multidisciplinar Nutrição, Diabetes e Determinantes Socioculturais em Índios Kamaiurá, fruto de convênio entre a Universidade Federal de São Paulo/ Escola Paulista de Medicina (Unifesp/EPM) e a Pontifícia Universidade Católica de São Paulo (PUC-SP), com apoio financeiro da Fundação Nacional de Saúde (Funasa) e da Organização das Nações Unidas para a Educação, a Ciência e a Cultura (Unesco).

Referências Bibliográficas

COALE, A. J. G HOOVER, E. M. Population Growth and Economic Development in LowIncome Countries. Princeton: Princeton University Press, 1958.

FREEDMAN, R. The Sociology of Human Fertility. England: Basil Blackwell, 1963.

GALVÃO, E. Apontamentos sobre os índios Kamaiurá. In: CARVALHO, J. C. M.; LIMA, P. E. G GALVÃO, E. (Orgs.) Observações Zoológicas e Antropológicas na Região dos Formadores do Xingu. Rio de Janeiro: Imprensa Nacional, 1949. p.31-48.

JUNQUEIRA, C. Os Índios do Ipavu: um estudo sobre a vida do grupo Kamaiurá. 2.ed. São Paulo: Ática, 1978.

MOTTA, J. L. A Epidemia de Sarampo no Xingu. Relatório apresentado à direção do Serviço de Proteção aos Índios, 1954. (Mimeo.)

RIBEIRO, D. Os Índios e a Civilização. Rio de Janeiro: Civilização Brasileira, 1970.

SINGER, P. Dinâmica Populacional e Desenvolvimento. São Paulo: Centro Brasileiro de Análise e Planejamento - Cebrap, 1970. 


\section{Estudo Demográfico dos Sateré-Mawé: um exemplo de censo participativo}

\section{Introdução}

O Diagnóstico Sócio-Demográfico Participativo da População Sateré-Mawé nasceu, por volta de fevereiro de 2002, da convergência de interesses de um grupo de instituições e organizações indígenas e não indígenas, governamentais e não governamentais, objetivando conhecer as condições de vida e de sustentabilidade dos povos indígenas da Amazônia Brasileira e, em especial, do Estado do Amazonas. Naquela ocasião, o Governo do Estado do Amazonas, por meio da Fundação Estadual de Política Indigenista (Fepi), propôs um programa de sustentabilidade econômica voltado às comunidades sateré-mawé. ${ }^{1} \mathrm{O}$ programa previa como uma das principais atividades a identificação das condições sociais e econômicas dessas comunidades.

A articulação institucional para conceber o projeto, conduzida pela Fepi, resultou na consolidação de um conjunto de entidades parceiras, reunindo a Universidade Federal do Amazonas (Ufam), a Fundação Joaquim Nabuco, a Coordenação das Organizações Indígenas das Amazônia Brasileira (Coiab), a Fepi e a Secretaria de Educação do Estado do Amazonas, representada pela sua Gerência de Educação Escolar Indígena, e, sobretudo, com o apoio financeiro e técnico do Fundo das Nações Unidas para a Infância (Unicef).

O projeto passou a contar também com o apoio das organizações indígenas sateré-mawé, da Fundação Nacional de Saúde (Funasa), da Fundação Nacional do Índio (Funai), das prefeituras municipais dos municípios abrangidos e do Fundo de População das Nações Unidas (Fnuap).

A proposta foi aceita pelas instituições envolvidas nas discussões preliminares e o Instituto de Estudos sobre a Amazônia da Fundação Joaquim Nabuco assumiu a responsabilidade de elaborar um projeto para viabilizá-la. Posteriormente, tendo a Fundação Joaquim Nabuco encerrado suas atividades de pesquisa na Região Norte, a coordenação técnica do Projeto ficou sob a responsabilidade da Universidade Federal do Amazonas.

No transcorrer da fase de articulação institucional para conceber o projeto emergiu o consenso de que o diagnóstico deveria contemplar um forte componente 
participativo das comunidades sateré-mawé, a exemplo do Censo Indígena Autônomo do Rio Negro, levado a efeito em 1992 pela Federação das Organizações Indígenas do Rio Negro (Foirn) (ver Azevedo, neste volume). O presente diagnóstico foi, portanto, pensado e implementado respeitando e promovendo a participação das comunidades locais, tornando-se uma experiência inovadora e pioneira no que diz respeito à ampla articulação institucional e participação da população alvo, sendo virtualmente uma experiência em condições de ser replicada no contexto de atividades da mesma natureza que possam ser realizadas na região amazônica, num futuro próximo.

\section{Objetivos e metodologia}

Os objetivos do diagnóstico foram: estudar as características demográficas (estrutura por sexo e idade, fecundidade, mortalidade, distribuição espacial, comportamento migratório) da população residente na área indígena em questão; analisar a ocupação dos moradores, incluindo tipos de atividade produtiva, meios técnicos de produção, formas de remuneração, destino da produção, salários, local de trabalho etc.; identificar a situação educacional das crianças, jovens e adultos; verificar as condições de saúde da população, com ênfase para a morbidade e a mortalidade, a saúde da mãe e da criança, o acesso aos serviços de saúde e a qualidade do atendimento prestado, a medicina tradicional etc.; examinar as condições de vida das coortes mais vulneráveis, como crianças e idosos; identificar as práticas religiosas na comunidade e suas relações com outros fatores sociodemográfico-culturais locais; verificar o domínio e a extensão de uso da língua sateré-mawé.

No levantamento das informações necessárias ao conhecimento da realidade sociodemográfica e ocupacional e das condições de vida da população sateré-mawé, residente nas terras indígenas e nas cidades, foi desenvolvido e aplicado um instrumento de coleta (questionário). Por solicitação das lideranças sateré-mawé, que desejavam a obtenção de números definitivos sobre o volume populacional, e para garantir a existência de informações no âmbito de cada comunidade, o levantamento teve caráter censitário, isto é, com cobertura de todos os residentes, tanto nas terras indígenas como nas cidades.

: Nas áreas indígenas, não obstante a ausência de algumas famílias, o aspecto censitário do levantamento não foi comprometido, pois, mesmo em caso de ausência, o mínimo de informações (pelo menos o sexo e a idade dos ausentes) poderia ser obtido com o. tuxaua (chefe de um grupo local ou aldeia), o agente indígena de saúde ou outros moradores. Isso significa que dificilmente um morador das terras indígenas tenha deixado de ser entrevistado ou contabilizado. Já nas cidades não ocorreu o mesmo, pois se fazia necessário localizar, um por um, todos 
os moradores sateré-mawé, cuja condição de residentes era informada por parentes indígenas ou, mesmo, por moradores não indígenas. Freqüentemente, uma pessoa, ao ser entrevistada, poderia indicar outra pessoa ou família conhecida que ainda não tinha sido contatada para entrevista. Apesar desse esforço para a localização de todo morador sateré-mawé das cidades, é provável que algum morador ou mesmo alguma família tenha ficado de fora do levantamento.

Considerou-se como morador sateré-mawé aquele que tem residência fixa e declarada nas terras indígenas, ou nas cidades percorridas, e é reconhecido pelas comunidades sateré-mawé como pertencente a suas famílias e que se autoidentifica (ou identifica seus filhos ou outras crianças da casa) como sateré-mawé. Os moradores identificados pelos entrevistadores como não indígenas que, por qualquer motivo, declararam-se sateré-mawé, não foram entrevistados ou tiveram sua entrevista cancelada pela coordenação do levantamento.

Conforme constante no próprio título, este diagnóstico sociodemográfico tem caráter participativo, à medida que: no levantamento, as lideranças saterémawé tiveram papel importante, tal como ocorreu durante o processo de discussão e elaboração do questionário da pesquisa e da operacionalização do levantamento dos dados; o tuxaua-geral de cada área (representante de todos os tuxauas da área) integraram a equipe de campo, orientando-a e facilitando o contato com as comunidades; os professores indígenas e os agentes indígenas de saúde assessoraram a coordenação técnica do diagnóstico, no planejamento de atividades e na operacionalização do trabalho de campo; todas as entrevistas foram realizadas pelos professores, agentes de saúde e alunos sateré-mawé; a disseminação e a popularização dos resultados junto às comunidades será organizada e executada pelos professores indígenas.

\section{Levantamento nas cidades}

Em cada uma das cidades abrangidas, foram realizadas, nos dias que precederam os levantamentos, atividades preparatórias com participação da população indígena residente, de suas lideranças e de autoridades e técnicos de órgãos municipais, estaduais e federais, além de representantes de organizações não-governamentais (ONGs) e da Diocese de Parintins. De um modo geral, tais atividades compreenderam: informe e discussão sobre o levantamento censitário na cidade, o planejamento e as principais providências a serem adotadas para sua realização, tais como a seleção e treinamento dos entrevistadores, estratégia para o levantamento de campo etc.; seleção dos entrevistadores (estudantes saterémawé do ensino fundamental ou do médio) indicados pelas lideranças indígenas locais; localização e mapeamento preliminar da população sateré-mawé residente 
na cidade, com apoio das lideranças indígenas e de instituições como Funai, Funasa, Prefeituras Municipais.

\section{Levantamento nas comunidades indígenas}

A estratégia de cobertura nas terras indígenas foi elaborada com base nas informações e nas sugestões fornecidas pelos professores, agentes da saúde e lideranças que participaram das atividades de coleta dos dados.

Dadas as características geográficas das terras habitadas pelos SateréMawé, o levantamento das informações foi feito, ali, exclusivamente por transporte fluvial. Nos rios Andirá e Marau, a equipe de campo (coordenação, entrevistadores e o tuxaua-geral de cada área) permaneceu todo o tempo alojada em barco com motor de centro. No Uaicurapá e no Koatá-Laranjal, por causa do tamanho reduzido da equipe de campo, utilizaram-se como transporte as 'voadeiras' (lanchas de pequeno porte, que consistem em canoas de alumínio equipadas com motores de popa).

Os membros da coordenação da pesquisa foram responsáveis pela organização das atividades nas comunidades e pela crítica dos questionários preenchidos. Na chegada em cada comunidade, o tuxaua-geral, ou, na ausência deste, um professor ou agente da saúde da equipe (este último, no caso do Rio Andirá), apresentava ao tuxaua da comunidade os principais aspectos da pesquisa, salientando sua importância para a população sateré-mawé e solicitando autorização para o levantamento local. Após ser concedida a autorização, um membro da coordenação técnica procurava o agente indígena de saúde para solicitar a relação dos moradores registrados no censo da Funasa, a localização das moradias de cada família e a condição de presença ou ausência dos responsáveis pelos domicílios. ${ }^{2}$ $\mathrm{Na}$ ausência dos agentes da saúde, as informações eram solicitadas ao próprio tuxaua ou a outro morador bem informado. De posse de tais informações, o coordenador da pesquisa na comunidade organizava a distribuição dos entrevistadores pelas residências. Após o preenchimento, os questionários eram entregues aos membros da equipe técnica, para serem criticados. Conforme o caso, os erros de preenchimento eram discutidos e, se necessário, o entrevistador voltava à residência para providenciar as correções.

Participaram do levantamento da área indígena do Marau/Urupadi, além do grupo de coordenação técnica da pesquisa, 16 professores e dois alunos saterémawé residentes na área, o presidente da Associação dos Tuxauas Sateré-Mawé dos Rios Marau e Urupadi (Tumupe) e o tuxaua-geral da referida área. No Andirá, a equipe contou com 13 professores sateré-mawé, dois agentes indígenas da saúde, dois professores da área do Uaicurapá e o tuxaua-geral do Andirá. No Uaicurapá 
participaram dois professores e um elemento da coordenação e, no Koatá-Laranjal, um membro da coordenação e um professor residente no Andirá.

Para o levantamento das áreas do Andirá e do Marau, os prefeitos dos municípios onde elas se situam (respectivamente, Barreirinha e Maués) solicitaram a inclusão, na pesquisa, de perguntas sobre a posse da documentação pessoal pelos moradores. Assim, os dados levantados nessas áreas incluem, também, a situação de os moradores terem ou não CPF, RG, Título Eleitoral e Carteira Profissional.

\section{Abrangência geográfica}

A investigação foi realizada nas sedes dos municípios de Maués, Parintins, Barreirinha e Nova Olinda do Norte (novembro de 2002 a janeiro de 2003) e nas Terras Indígenas do Andirá-Marau e Koatá-Laranjal (junho a outubro de 2003). Não foi coberta a população sateré-mawé residente em Manaus (AM), nem a população das áreas rurais não-indígenas dos municípios citados.

No total, foram levantados exatamente 8.500 residentes que se autodenominaram Sateré-Mawé (ou que assim foram denominados por pais ou responsáveis), correspondentes a um total de 1.759 domicílios. Desses domicílios, 228 (com 998 moradores) situam-se nas áreas urbanas e 1.531 (com 7.502 moradores) nas terras indígenas. Segue-se a Tabela 1 com a distribuição dos entrevistados por local de residência.

Tabela 1 - Números de domicílios levantados e de moradores entrevistados segundo os locais de residência

\begin{tabular}{lcc}
\hline Local de residência & Domicílios & Moradores \\
\hline Terras indígenas & 1531 & 7502 \\
Marau & 779 & 3288 \\
Andirá & 662 & 3795 \\
Uaicurapá & 59 & 292 \\
Koatá-Laranjal & 31 & 127 \\
\hline Áreas urbanas (municípios) & 228 & 998 \\
Maués & 48 & 200 \\
Parintins & 115 & 512 \\
Barreirinha & 50 & 276 \\
Nova Olinda do Norte & 3 & 10 \\
\hline Total & 1747 & 8500 \\
\hline
\end{tabular}

Fonte: Diagnóstico Sócio-Demográfico Participativo da População Sateré-Mawé. 
É importante esclarecer que, em razão do esforço de conferir caráter censitário à pesquisa, a população contabilizada corresponde à totalidade dos residentes nos locais mencionados. Na área indígena, todavia, apesar de terem sido contabilizados, não foram entrevistados os que não se encontravam presentes no momento da pesquisa e os moradores ausentes há mais tempo. Vale esclarecer ainda que, nas cidades, é provável que não tenham sido incluídos na pesquisa os residentes sateré-mawé desconhecidos dos que foram entrevistados e que, portanto, não foram localizados para efeito de entrevista.

\section{Disseminação dos resultados}

Em uma primeira instância, a disseminação das informações entre a população sateré-mawé estará se realizando por meio de seminários e reuniões nas sedes dos municípios e nas áreas indígenas. Para tanto, uma versão do Relatório Técnico na língua sateré-mawé, em formato simplificado, será elaborada de forma a facilitar a discussão dos resultados entre as lideranças e viabilizar a divulgação e a discussão nas comunidades. Assim, as informações levantadas retornarão para a população em um formato mais elaborado e de entendimento mais fácil. Participarão desses seminários as lideranças indígenas, os professores, os agentes de saúde e outros indígenas, como também pessoas e instituições ligadas ao movimento e às questões indígenas.

As escolas indígenas deverão ser um local privilegiado de divulgação das informações junto aos estudantes. A esse propósito, é importante ressaltar o papel reservado aos professores na disseminação dos resultados da pesquisa, uma vez que eles serão multiplicadores junto às crianças, aos adolescentes e aos jovens indígenas. Serão os professores, portanto, que irão proporcionar aos alunos o acesso às informações sobre as condições de vida de seu povo.

Evidentemente, o principal beneficiário do diagnóstico participativo será o próprio povo Sareré-Mawé, que passa a contar com ampla e valiosa base de dados a ser utilizada segundo seus próprios critérios e interesses. Essa apropriação dos resultados do diagnóstico pelos próprios índios colocará a seu dispor um importante instrumento de apoio para a elaboração de programas de desenvolvimento em distintas áreas, tais como: meio ambiente, habitação, educação, saúde, produção econômica entre outras. Os dados contidos no diagnóstico poderão ainda ser utilizados na produção e no acompanhamento de projetos de desenvolvimento sustentável e outros correlacionados (produção de guaraná, apicultura, piscicultura, coleta de lixo etc.), desenvolvidos pelas próprias organizações sateré-mawé. 
Em especial, em razão do significativo peso que têm na pesquisa as informações sobre saúde e educação das crianças e dos adolescentes, o diagnóstico participativo deverá constituir-se em base importante para a elaboração de programas de intervenção objetivando a melhoria da atual situação da infância e da adolescência sateré-mawé.

Participando do diagnóstico na dupla condição de moradores e entrevistadores de suas próprias comunidades, envolvendo-se no desenvolvimento dos trabalhos em quase todas as suas etapas (elaboração dos instrumentos de coleta, divulgação do Projeto nas comunidades, contato com as lideranças das comunidades, seleção dos entrevistadores, divulgação dos resultados e, evidentemente, realização das entrevistas), os Sateré-Mawé vêm vivenciando uma experiênciạ quase única no Brasil de auto-avaliação das condições de vida de um povo indígena.

\section{Antecedentes históricos}

Os Sateré-Mawé habitam a Terra Indígena Andirá-Marau, localizada na região do médio rio Amazonas, entre os estados do Amazonas e Pará. Ocupam também uma pequena área dentro da Terra indígena Koatá-Laranjal em coabitação com o povo Munduruku.

Esta população indígena é conhecida regionalmente como 'Mawés'; porém, autodenomina-se Sateré-Mawé. Sateré ${ }^{3}$ é o clã mais importante dessa sociedade indígena, do qual se indica, tradicionalmente, a linha sucessória dos tui'sas - tuxaua ou principal (Lorenz, 1992; Batista, 2001). E a língua é o mawé, do tronco lingüístico Tupi.

Este povo é originário de uma vasta área entre os rios Tapajós e Madeira, delimitado ao norte pelas Ilhas Tupinambaranas (no rio Amazonas) e ao sul pelas cabeceiras do rio Tapajós. Seu local de origem, segundo Batista (2001:2), é "à margem esquerda do rio Tapajós, numa região sagrada para nossa gente, de densa floresta e cheio de pedras, e, como dizem os velhos, 'nesse lugar as pedras falam' ".

O primeiro registro histórico do contato desse povo com os 'brancos' data de 1669, com a fundação de missão jesuíta na Ilha Tupinambarana, atual Parintins. Por causa das guerras com os Munduruku e Parintintim e o contato com os portugueses, : os Sateré-Mawé perderam grande parte de seu território original (Lorenz, 1992).

Posteriormente, em 1835, lutando ao lado dos Munduruku e dos Mura, como também de outras tribos indígenas do rio Negro, os Sateré aderiram ao movimento cabano até que, em 1839, o conflito foi debelado. Em razão das epidemias, das lutas e das perseguições aos povos indígenas que combatiam ao 
lado dos cabanos, enormes áreas da Amazônia foram devastadas, fato que provocou os deslocamentos desses grupos populacionais de seus territórios ancestrais e um processo de depopulação (Lorenz, 1992).

Segundo relatos de viajantes, desde o século XVIII o território dos Sateré vem sendo paulatinamente reduzido. Essa redução se deu a partir da chegada das tropas de resgate que penetraram grandes áreas da Amazônia; da implantação de missões jesuítas e carmelitas ao longo dos principais rios amazônicos; da busca desenfreada pelas chamadas drogas do sertão; com a exploração da borracha durante o século XIX e início do XX; e, por fim, da "expansão econômica das cidades de Maués, Barreirinha, Parintins e Itaituba para o interior dos municípios, alocando fazendas, extraindo pau-rosa, abrindo garimpos, dominando a economia indígena através de regatões" (Lorenz, 1992:18). As cidades de Maués, Parintins e Itaituba, inclusive, foram fundadas sobre restos de malocas dos Sateré-Mawé.

\section{Aspectos contemporâneos da territorialidade Sateré-Mawé}

Atualmente, o território dos Sateré-Mawé (a Terra Indígena Andirá-Marau) localiza-se numa área na divisa dos estados do Amazonas e Pará. O processo de demarcação foi iniciado em 1978, quando foi realizada a delimitação da área por técnicos da Funai, sob orientação dos índios. No entanto, durante dois anos os trabalhos foram interrompidos, período em que os Sateré-Mawé sofreram várias ameaças de invasão do seu território. Dentre essas invasões podemos citar o projeto de construção da estrada Maués/Itaituba, que tinha por objetivo ligar Maués ao sul do país e que cortaria a Terra Indígena ao meio, impossibilitando, assim, a demarcação de acordo com o traçado exigido pelos índios. Após a constatação de uma série de irregularidades, esse projeto foi embargado. Outras invasões importantes foram as realizadas pela empresa francesa de petróleo Elf-Aquitaine durante os anos de 1981 e 1982. Interessada na exploração desse mineral, a empresa realizou estudos sismológicos que causaram grandes prejuízos à flora e à fauna da área. Além disso, provocaram a morte de alguns Sateré-Mawé com a detonação de cargas de dinamite enterradas naquela área.

Além dessas invasões, ocorreram também penetrações de garimpeiros provenientes da região do rio Tapajós e de posseiros moradores nas proximidades dós limites fronteiriços da Terra Indígena.

\section{Demarcação das terras Sateré-Mawé}

No início de 1981, o processo de demarcação foi retomado por conta das cobranças constantes dos Sateré-Mawé junto à Funai, intensificadas após as invasões 
da Elf-Aquitaine, de forma que em 06/05/1982 foi publicada a Portaria de demarcação e sua homologação ocorreu em 06/08/1986. Assim, a Terra Indígena do Andirá-Marau compreende atualmente uma área de 788.528 ha e perímetro de 477,7 km. No estado do Amazonas está distribuída pelos municípios de Maués (148.622 ha), Parintins (30.994 ha) e Barreirinha (143.044 ha), e no estado do Pará pelos municípios de Itaituba (350.615 ha) e Aveiro (115.253 ha).

Os principais rios da área são o Marau, o Miriti, o Urupadi, o Manjuru, o Andirá e o Uaicurapá, compreendendo, apenas, uma pequena extensão do território tradicional. Todavia, segundo o ponto de vista dos Sateré-Mawé, o que conseguiram preservar constitui uma área privilegiada do território ancestral. Por se caracterizarem como índios da floresta, do centro, até início do século XX escolhiam para estabelecer suas aldeias as regiões mais centrais da mata, próximas às nascentes dos rios. A abundância de caça, de guaraná (Paullinia sorbilis), de palmeiras como o açaí, tucumã, pupunha e bacaba, importantes para a alimentação, e outros vegetais, é muito maior nessas áreas (Lorenz, 1992:22-24).

\section{Expansão de aldeias}

As antigas aldeias Araticum Velho e Terra Preta, nas cabeceiras do rio Andirá, foram os pólos que deram origem às aldeias que surgiram ao longo das margens desse rio nos últimos oitenta anos. Da mesma forma, a aldeia Marau Velho foi o pólo difusor das aldeias criadas ao longo dos rios Marau, Manjuru, Urupadi e Miriti. Hoje aquelas aldeias originais não existem mais, elas desapareceram em torno da década de 1920. De acordo com observações dos próprios índios, as aldeias que ficam nas proximidades das antigas aldeias Araticum Velho, Terra Preta e Marau Velho guardam melhor as tradições milenares do povo sateré-mawé, quando comparadas com as aldeias mais próximas das cidades (Batista, 2001:2-3).

Nos últimos oitenta anos, uma série de fatores vem provocando a multiplicação e estabelecimento das comunidades/aldeias nas margens dos rios Andirá e Marau, em localidades mais próximas das cidades, provocando mudanças significativas na localização tradicional das mesmas e, conseqüentemente, no modo de vida do povo sateré-mawé. Dentre esses fatores podemos mencionar a interferência das missões religiosas (tanto católicas, quanto evangélicas), do órgão oficial encarregado de garantir a preservação das Terras Indígenas (inicialmente o Serviço de Proteção aos Índios - SPI e posteriormente a sua sucessora, a Funai), dos regatões e das epidemias. 


\section{Sateré-Mawé em território Munduruku: Terra Indígena Koatá-Laranjal}

Os Sateré-Mawé, além da Terra Indígena Andirá-Marau, também ocupam parte da Terra Indígena Koatá-Laranjal. Os grupos ali estabelecidos são oriundos da região do rio Andirá, mais especificamente da comunidade Ponta Alegre. Após conflito ocorrido nessa aldeia em 1965, um grupo de índios saiu dessa área e dirigiu-se à Terra Indígena dos Waimiri-Atroari, no rio Camanaú, afluente do rio Negro. Ali estabeleceram uma comunidade sateré-mawé; contudo, em virtude de uma série de dificuldades, especialmente a hostilidade do povo Waimiri-Atroari, tiveram que deixar a área. Ao saírem dali, instalaram nova comunidade no rio Mari-Mari, na Terra indígena Koatá-Laranjal, desta vez com a concordância do povo indígena que ali residia, os Munduruku. Essa mudança ocorreu no ano de 1980 e, desde então, os Sateré-Mawé foram aos poucos se adaptando ao novo local, criando o seu próprio hábitat, construindo suas casas, plantando suas roças, caçando, pescando, erigindo, enfim, a nova comunidade que denominaram de Vila Batista II, pois todas as famílias que para ali se deslocaram são da mesma família (Batista).

No entanto, após alguns anos de moradia, quando a comunidade já estava razoavelmente estruturada, alguns Sateré-Mawé retornaram à Terra Indígena AndiráMarau, estabelecendo-se em área diferente daquela onde moravam originariamente. Foram para o rio Uaicurapá, no município de Parintins, onde ergueram nova aldeia com o mesmo nome (Vila Batista). Esta nova mudança ocorreu no início da década de 90 e existem, atualmente, na área do Uaicurapá, quatro aldeias.

\section{Aldeias no território Sateré-Mawé}

No presente, na Terra indígena Andirá-Marau, existem 91 aldeias distribuídas ao longo dos principais rios e igarapés que cortam essa área. Residem aproximadamente 1.600 famílias com população de 7,5 mil habitantes. A região mais populosa localiza-se ao longo do rio Andirá e seus principais tributários, no município de Barreirinha, onde existem 50 aldeias com população em torno de 3,8 mil pessoas, com média de cinco pessoas por domicílio. A outra área com população expressiva localiza-se na região do rio Marau, município de Maués, com 37 aldeias, 3,3 mil pessoas e 4,9 pessoas por domicílio.

A região do rio Uaicurapá, no município de Parintins, é a que apresenta a maior média de pessoas por domicílio $(5,3)$ dentro da Terra Indígena Andirá-Marau. Conta, porém, com menor número de comunidades, ou seja, apenas quatro. Nesta região encontramos aproximadamente 300 pessoas. 
O presente trabalho pretende mostrar algumas características demográficas dos Sateré-Mawé, com base nos dados obtidos no referido levantamento. Muitas das informações aqui contidas constam do correspondente Relatório Técnico (Universidade Federal do Amazonas et al., 2004) e se referem ao volume dos efetivos populacionais sateré-mawé, sua distribuição espacial, o quadro urbano-rural dessa população, a repartição etária e por sexo. Todas essas informações são tratadas analiticamente como forma de contribuir para a compreensão da complexa realidade desse povo indígena. Com o intuito de procurar entender um dos componentes da dinâmica demográfica dos Sateré-Mawé, a natalidade e a fecundidade são tratadas do ponto de vista comparativo entre as diferentes áreas habitadas pelos SateréMawé, inclusive entre as terras indígenas e as áreas urbanas.

\section{Distribuição espacial da população}

Na Tabela 2, é mostrada a população das terras indígenas habitadas pelos Sateré-Mawé, com suas áreas correspondentes, assim como a das cidades em que foi realizado o levantamento sociodemográfico.

Tabela 2 - População Sateré-Mawé segundo o quadro de residência e sexo, 2002-2003

\begin{tabular}{lccc}
\hline & Homens & Mulheres & Total \\
\hline Áreas urbanas & 477 & 521 & 998 \\
Parintins & 247 & 265 & 512 \\
Barreirinha & 139 & 137 & 276 \\
Maués & 87 & 113 & 200 \\
Nova Olinda do Norte & 4 & 6 & 10 \\
\hline Terras Indígenas & 3.811 & 3.691 & 7.502 \\
Andirá & 1.925 & 1.867 & 3.795 \\
Marau & 1.663 & 1.625 & 3.288 \\
Uaicurapá & 155 & 137 & 292 \\
Koatá-Laranjal & 68 & 59 & 127 \\
\hline Total & 4.288 & 4.212 & 8.500 \\
\hline
\end{tabular}

Fonte: Diagnóstico Sócio-Demográfico Participativo da População Sateré-Mawé.

No Rio Andirá estão localizados 49 aldeias, habitadas por 3.795 índios. Nesta região, as maiores aldeias são: Ponta Alegre (397 hab.), Simão I (287 hab), Molongotuba (281 hab.), Vila Nova (270 hab.), Castanhal (185 hab.), Conceição 
(144 hab.), Araticum Novo (148 hab.), Fortaleza (121 hab.), Umirituba (136 hab.) e Nova América (105 hab.). As outras 39 comunidades da região são habitadas por menos de 100 indivíduos cada uma, chegando algumas a ter menos de 20 habitantes, como Ponto Alto, São Miguel, Boa Vista, Itaubal, São João, Jatuatuba I, Limoal, São Gabriel, São Marcos, São Sebastião do Arco, Tigre e Ipiranga.

No Rio Marau vivem 3.288 Sateré-Mawé, distribuídos em 37 comunidades. As maiores aldeias são Santa Maria (335 hab.), Vila Nova II (316hab.), Campo do Miriti (233 hab.), Nossa Senhora de Nazaré (192 hab.), Boas Novas (144 hab.), Nova Aldeia (106 hab.), Marau Novo (121 hab.), Kuruatuba (115 hab.) e Menino Deus (101 hab.). As 28 comunidades restantes possuem menos de 100 habitantes cada, mas nenhuma delas tem, como o Rio Andirá, aldeias com população inferior a 20 moradores.

Ainda na Terra Indígena Andirá-Marau, a região do Rio Uaicurapá possui quatro comunidades Sateré-Mawé, habitadas por 292 pessoas - Vila Batista I (109 hab.), São Francisco (65 hab.), Nova Alegria (59 hab.) e Vila da Paz (59 hab.).

Existe apenas uma aldeia sateré-mawé na Terra Indígena do KoatáLaranjal, a Vila Batista II, com 127 habitantes. As demais comunidades dessa terra indígena são habitadas pela etnia Munduruku.

\section{Composição por sexo e idade}

O padrão demográfico dos Sateré-Mawé é típico de povos indígenas em processo de recuperação populacional, caracterizando-se por níveis de natalidade elevados e por níveis de mortalidade comparáveis aos do país como um todo.

Como reflexo da elevada natalidade, a população das terras indígenas Andirá-Marau e Koatá-Laranjal, e das quatro regiões em que se subdividem, apresentam estruturas populacionais muito jovens, com os menores de 15 anos representando $52,7 \%$ da população (Tabela 3). Por outro lado, os moradores de 50 ou mais anos de idade constituem $9,4 \%$ da população total, proporção bastante superior aos 4,1\% encontrados nas áreas rurais do estado do Amazonas (IBGE, 2000). É provável que haja uma sobreenumeração da população idosa sateré-mawé, decorrente da entrada precoce de parte desse contingente no conjunto da população aposentada.

Estudos demográficos recentes indicam a característica jovem das populações indígenas da Região Amazônica que retomaram altos níveis de fecundidade e se encontram em processo de recuperação populacional. Os Xavánte de Pimentel Barbosa e os de Sangradouro Volta-Grande apresentam proporções de população com menos de 15 anos de idade que variam de $48 \%$ a $57 \%$ (Flowers, 1994; Souza G Santos, 2001). Entre os povos moradores do Parque Indígena do 
Xingu, como os Kaiabi, Juruna e Waurá, Pagliaro (2002) e Pagliaro et al. (2001 e 2003) encontraram estruturas etárias com proporções de menores de 15 anos situadas entre $49 \%$ a $58 \%$.

Ainda na Tabela 3, notam-se pequenos diferenciais na participação da população menor de 15 anos entre as áreas indígenas e entre as cidades. Entretanto, devido ao número relativamente reduzido de moradores em algumas dessas áreas, não se deve, de imediato, levantar hipóteses de explicação dos diferenciais. Vale apenas ressaltar, nas terras indígenas, as proporções maiores de jovens nas áreas do Koatá-Laranjal e do Uaicurapá. Apesar de não serem marcantes essas diferenças, elas poderiam estar relacionadas com o fato de que as duas áreas apresentam população reduzida (Tabela 2), são de povoamento recente e se encontram relativamente distantes dos núcleos mais antigos dos povoados do Andirá e do Marau.

Tabela 3 - Distribuição da população por grandes grupos etários nas Terras Indígenas Andirá-Marau e Koatá-Laranjal, 2002-2003

\begin{tabular}{lcccc}
\hline & \multicolumn{4}{c}{ Idade } \\
\cline { 2 - 5 } & 0 a 14 anos & 15 a 49 anos & 50 anos e mais & Total \\
\hline Terras Indígenas & 52,7 & 37,9 & 9,4 & 100,0 \\
Marau & 53,2 & 38,2 & 8,6 & 100,0 \\
Andirá & 51,9 & 38,1 & 10,1 & 100,0 \\
Uaicurapá & 55,8 & 34,9 & 9,3 & 100,0 \\
Koatá-Laranjal & 56,9 & 34,7 & 8,7 & 100,0 \\
\hline Áreas urbanas & 45,1 & 45,2 & 9,8 & 100,0 \\
Parintins & 47,2 & 43.6 & 9,2 & 100,0 \\
Barreirinha & 44,1 & 54,0 & 9,9 & 100,0 \\
Maués & 41,0 & 48,5 & 10,5 & 100,0 \\
Nova Olinda do Norte & 50,0 & 40,0 & 10,0 & 100,0 \\
\hline Total & 51,8 & 38,8 & 9,4 & 100,0 \\
\hline
\end{tabular}

Fonte: Diagnóstico Sócio-Demográfico Participativo da População Sateré-Mawé.

O detalhamento das estruturas por idade e sexo dos Sateré-Mawé residentes nas terras indígenas e nas cidades está representado em forma de pirâmides etárias nas Figuras 1 e 2 .

A primeira pirâmide, referente aos moradores das terras indígenas, apresenta contorno semelhante e desenho compatível com o de estruturas populacionais jovens, caracterizadas por altos níveis de natalidade e de mortalidade, ou seja, possui uma base larga e seus retângulos se estreitam à medida que 
aumentam as idades. Destaca-se a irregularidade dessa pirâmide nas idades superiores a 45 anos, característica própria de populações indígenas que sofreram elevadas perdas populacionais por contato com a sociedade envolvente em anos relativamente recentes (até meados da década de 1960). A proporção relativamente elevada de idosos entre 60 e 70 anos poderia estar relacionada à aposentadoria precoce de parte importante da população idosa sateré-mawé, conforme visto anteriormente. Muitos desses moradores somente adquirem a Certidão de Nascimento no momento em que se faz necessária para a obtenção da aposentadoria.

Figura 1 - Repartição da população por sexo e idade nas Terras Indígenas

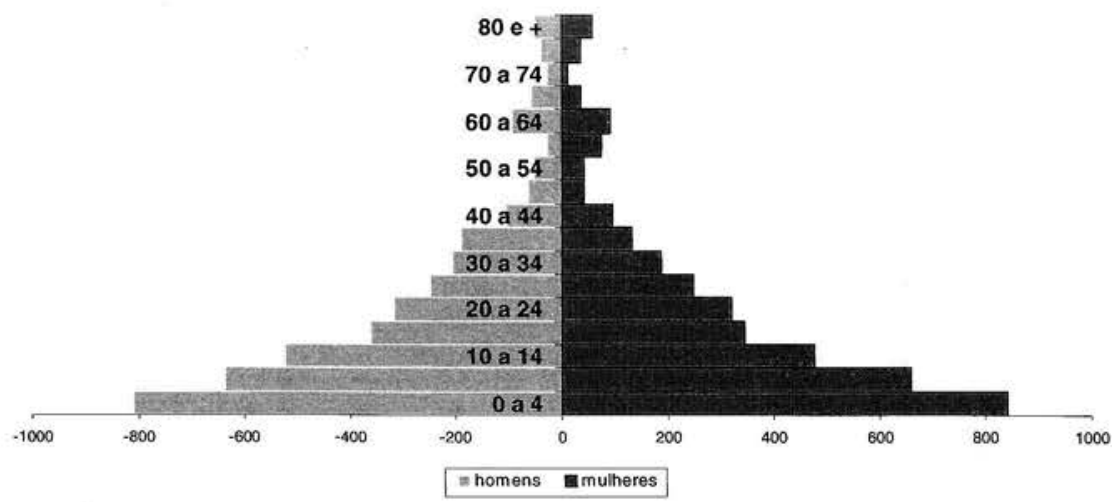

Fonte: Diagnóstico Sócio-Demográfico Participativo da População Sateré-Mawé.

Figura 2 - Repartição da população por sexo e idade na área urbana

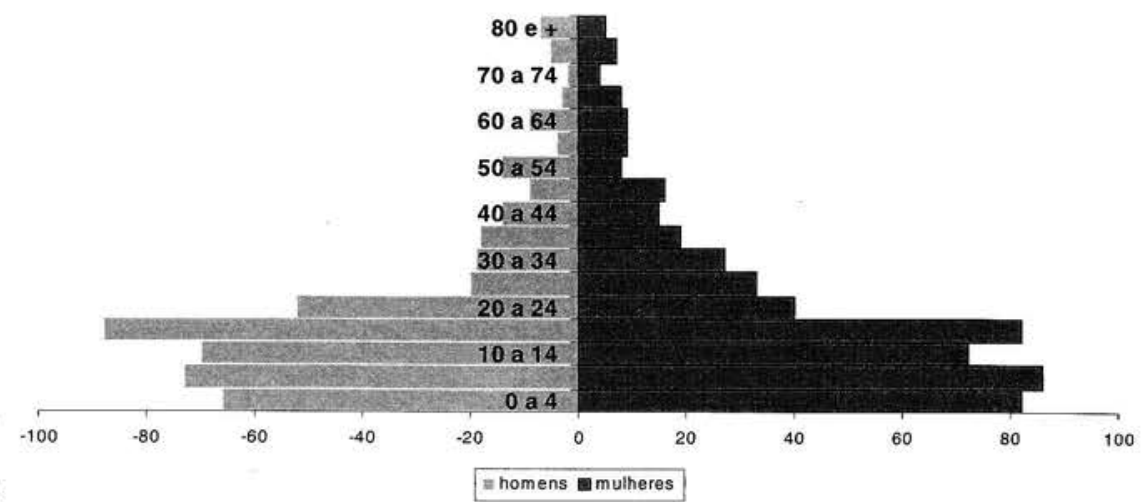

Fonte: Diagnóstico Sócio-Demográfico Participativo da População Sateré-Mawé.

Nas áreas urbanas (Figura 2), a pirâmide etária apresenta um padrão mais característico das populações com movimento migratório intenso, especialmente entre os 10 e 25 anos de idade. Na realidade são justamente os adolescentes e jovens, com predominância das mulheres, que vão completar seus estudos nas cidades. 
Convém salientar os diferenciais de gênero observados nas Figuras 1 e 2 , com vantagem para as mulheres com idade entre 15 e 24 anos.

$\mathrm{Na}$ Tabela 4, observa-se que, contrariamente ao que ocorre nas terras indígenas, a quantidade de mulheres sateré-mawé nas cidades é superior à de homens. A razão de sexo nas áreas indígenas é de 103,3 homens para cada 100 mulheres, bastante superior ao índice de 90,5 verificado nas cidades. Tais valores parecem estar indicando uma migração feminina superior à masculina com destino às cidades.

Outra questão importante quanto à distribuição por sexo é a superioridade de homens dos grupos de idade de 15 a 49 anos nas áreas indígenas. Esses grupos são justamente os que estão ligados aos padrões de reprodução da população. Como enfatiza Pagliaro (2002), é nessas faixas etárias que o equilíbrio entre os sexos é fundamental para determinar os padrões das uniões conjugais e da procriação. A exceção ocorre apenas nas áreas urbanas, como já foi mencionado anteriormente.

Tabela 4 - Distribuição da população por grandes grupos etários nas Terras Indígenas e na área urbana, 2003

\begin{tabular}{lccc}
\hline \multicolumn{1}{c}{ Regiões } & Homens & Mulheres & Razão de sexos \\
\hline Terras Indígenas & 3.747 & 3.628 & 103,3 \\
Marau & 1.635 & 1.597 & 102,4 \\
Andirá & 1.889 & 1.835 & 102,9 \\
Uaicurapá & 155 & 137 & 113,1 \\
Koatá-Laranjal & 68 & 59 & 115,3 \\
\hline Área Urbana & 478 & 525 & 91,0 \\
\hline Total & 4.225 & 4.153 & 101,7 \\
\hline
\end{tabular}

Fonte: Diagnóstico Sócio-Demográfico Participativo da População Sateré-Mawé.

\section{Fecundidade e reprodução}

Considerando-se estudos recentes sobre a fecundidade indígena no Brasil (Flowers, 1994; Souza G Santos, 2001, Pagliaro et al., 2001, Pagliaro, 2002, entre outros), os níveis de natalidade da população sateré-mawé apresentam-se próximos aos de outras etnias em processo de crescimento demográfico nas últimas décadas, após um longo período de tempo de redução populacional.

No ano que antecedeu o início da pesquisa em área urbana nasceram vivos 28 Sateré-Mawé, nas cidades de Barreirinha, Nova Olinda do Norte, Maués e 
Parintins (Tabela 5). Nas áreas indígenas, mais populosas, ocorreu um número bem maior de nascimentos vivos, 385 .

As discrepâncias entre o número de nascimentos ocorridos nas áreas urbanas e nas terras indígenas dão conta da diferença entre a fecundidade das mulheres que vivem nessas regiões. Com efeito, a Taxa Bruta de Natalidade das terras indígenas chega a 51,3, contra apenas 28,1 nas áreas urbanas. Mesmo tendo-se em conta a flutuação aleatória nos pequenos números referentes às cidades, fica evidente a diferença na natalidade entre esses dois espaços de observação.

Nas terras indígenas existem também diferenças entre os níveis de natalidade das duas áreas mais populosas (Marau e Andirá), que podem ser observadas na próxima tabela. Os valores respectivos de 54,1 e 47,7 nascimentos vivos para cada mil habitantes daquelas duas regiões revelam a possibilidade de distintos comportamentos reprodutivos de seus habitantes, o que, de certa forma, não deveria ser esperado, dada a semelhança das características sociais, econômicas e culturais nas duas áreas, além da relativa proximidade geográfica entre elas e da relativa facilidade de comunicação entre seus habitantes.

Tabela 5 - Nascidos vivos, taxa bruta de natalidade, taxa de fecundidade total e idade média à fecundidade nas Terras Indígenas AndiráMarau e Koatá-Laranjal e na área urbana, 2002-2003

\begin{tabular}{lcccc}
\hline \multicolumn{1}{c}{ Regiôes } & Nascidos vivos & $\begin{array}{c}\text { Taxa Bruta de Natalidade } \\
\text { (por mil hab.) }\end{array}$ & $\begin{array}{c}\text { Taxa de } \\
\text { Fecundidade Total }\end{array}$ & $\begin{array}{c}\text { Idade média à } \\
\text { fecundidade }\end{array}$ \\
\hline Terras Indígenas & 385 & 51,31 & 8,1 & 29,1 \\
Marau & 178 & 54,14 & 8,5 & 28,8 \\
Andirá & 181 & 47,69 & 7,9 & 29,9 \\
\hline Área Urbana & 28 & 28,06 & - & 31,4 \\
\hline Total & 413 & - & - & - \\
\hline
\end{tabular}

Nota: Não foram consideradas as áreas do Uaicurapá e do Koatá-Laranjal por causa do pequeno número de nascimentos ali registrados. No entanto, os nascimentos dessas áreas foram computados no cálculo das taxas da área indígena.

Fonte: Diagnóstico Sócio-Demográfico Participativo da População Sateré-Mawé.

Os níveis de fecundidade da população sateré-mawé são elevados, na casa de oito filhos por mulher (Tabela 5) e não apresentam paralelos com o que acontece na população não-indígena de qualquer parte do Brasil e da maioria dos demais países. No interior de algumas nações africanas, como os países de língua portuguesa (especialmente Angola e Moçambique, os mais populosos), ainda se encontram níveis de fecundidade como os verificados entre os Sateré-Mawé e em um expressivo número de povos indígenas no Brasil. Esse nível de fecundidade 
encontrado para a população feminina sateré-mawé é compatível com os níveis estimados para outros povos indígenas como os Kaiabi, na região do Xingu (Pagliaro, 2002), os Xavánte (Flowers, 1994; Souza G Santos, 2001) e outros.

Da mesma forma que se observou para a natalidade dos Sateré-Mawé, os níveis de fecundidade dessa população variam muito quando se comparam resultados das terras indígenas com os da área urbana e têm pequena variação no interior das terras indígenas. Os dados obtidos permitiram estimar a Taxa de Fecundidade Total para as áreas do Andirá e do Marau, indicando uma reduzida diferença entre elas. Assim, ainda de acordo com a Tabela 5, vê-se que a fecundidade das mulheres do Marau (8,5 filhos) é pouco superior às do Andirá (7,9 filhos), sugerindo a possível existência de fatores, não detectáveis em levantamentos do tipo do que foi realizado, que poderiam estar influindo no comportamento reprodutivo e no nível de fecundidade de cada uma delas.

Já no caso dos diferenciais entre terras indígenas e áreas urbanas, o reduzido número (28) de nascimentos declarados pelas mulheres em idade reprodutiva daquelas últimas não permite proceder às estimativas das taxas de fecundidade para efeito de comparação. Pode-se, no entanto, utilizar um indicador auxiliar nesses casos de pequenos números na estimativa da fecundidade. Trata-se do número de filhos por mulher, dado pelo quociente entre o número total de nascidos vivos no ano e o total de mulheres em idade fértil. Esse indicador tem o valor de 29,3 filhos por mulher para o Marau e de 25,0 para o Andirá, mostrando coerência com as taxas de fecundidade total de cada uma dessas áreas, vistas anteriormente. Contudo, seu valor para o total das terras indígenas (27,5 filhos por mulher) distancia-se significativamente do encontrado nas cidades (12,2 filhos por mulher), podendo significar prováveis diferenças entre o comportamento reprodutivo nas terras indígenas e na área urbana.

Assim, os resultados anteriores parecem indicar que a população saterémawé residente nas áreas urbanas próximas às terras indígenas, apesar do relativamente reduzido tempo de moradia nessas cidades, já esteja começando a adquirir hábitos reprodutivos da população brasileira não-indígena, situação que pode estar ocorrendo particularmente com as gerações mais novas. Essas hipóteses necessitam de ser investigadas com maior profundidade, tendo inicialmente como fonte de informações a base de dados do levantamento ora estudado. A utilização dessa base de dados, composta também por informações sobre educação, aspectos culturais, trabalho e ocupação, saúde reprodutiva e outras, seria, desse modo, um primeiro campo de buscas de explicações para esses outros contrastes verificados entre os Sateré-Mawé residentes nas terras indígenas e os moradores nas cidades próximas.

Na população feminina sateré-mawé, a idade em que as mulheres, em média, têm o maior número de filhos é aos 29,2 anos. Entretanto, foram encontradas 
meninas de 13 anos que já tiveram filhos e mulheres com idade acima de 49 anos que ainda continuam tendo filhos. Essa idade média à reprodução nas cidades está 2,3 anos acima da referente à área indígena.

A fecundidade da população sateré-mawé também pode ser observada com base nas taxas específicas de fecundidade por idade, que mostram o comportamento reprodutivo das mulheres por grupos etários qüinqüenais (Figura 3). De acordo com as informações levantadas, as taxas de fecundidade das mulheres sateré-mawé são mais elevadas nas idades mais jovens, com pico no grupo etário 20-24. Isto faz com que o padrão reprodutivo dessas mulheres tenha uma configuração 'rejuvenescida' e, não obstante a significativa diferença nos níveis, apresente alguma semelhança com o atual padrão das mulheres das áreas rurais do Estado do Amazonas. Ressalte-se ainda a comparação entre esse padrão saterémawé e o da população rural do Brasil na década de 1960, cuja curva sugere um nível de fecundidade bastante próximo (como, de fato, o é, conforme Carvalho, 1978). A fecundidade atual dos Sateré-Mawé é mais elevada que a do Brasil nos dois primeiros grupos etários e mais reduzida nos demais (com exceção do último). Nessas primeiras idades ocorrem 27\% dos partos no Brasil de 1960/1970 e 38\% nas terras sateré-mawé de 2003. E, nas duas populações, a fecundidade continua relativamente elevada nos grupos etários subseqüentes.

Figura 3 - Diferenciais de fecundidade por idade nas área indígena do Andirá-Marau, Brasil e no estado do Amazonas, 1960/70, 2000 e 2003

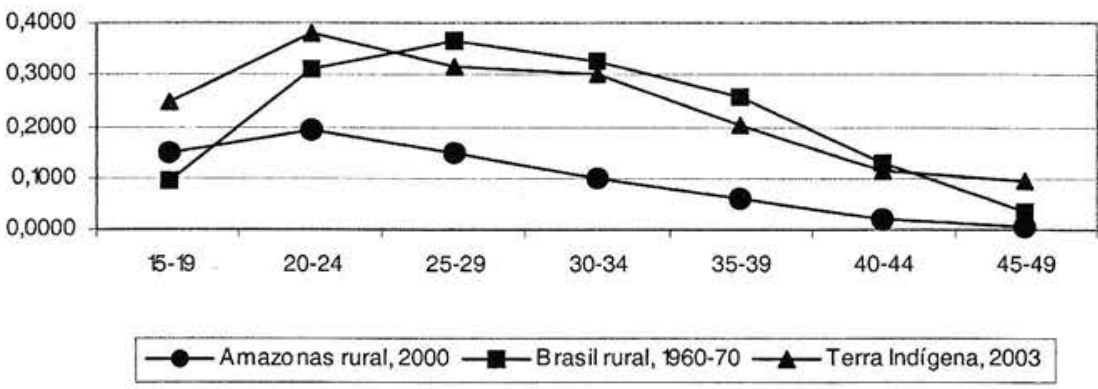

Fontes: Dados brutos - Diagnóstico Sócio-Demográfico Participativo da População Sateré-Mawé (2003); população rural do Amazonas: IBGE, 2000; níveis de fecundidade em:1960/1970: Carvalho, 1978.

Lamentavelmente, não se dispõe de informações históricas sobre a fecundidade dos Sateré-Mawé, com as quais se pudesse avaliar a evolução dos padrões anteriores e verificar o caráter dos elevados valores atuais para as idades jovens. A utilização dos dados censitários de 2000 poderia ser útil na compreensão 
do fenômeno, à medida que as estimativas resultantes possam permitir a comparação dos padrões atuais de fecundidade com os de outros povos indígenas da Região Amazônica. De qualquer forma, ficam dados, assim, os primeiros passos para a discussão sobre os atuais níveis e padrões de fecundidade do povo SateréMawé, tais como estimados a partir do levantamento realizado em 2003.

Notas

1 Os etnônimos são grafados em minúscula quando usados como adjetivos e com letras maiúsculas quando substantivos. Segundo convenção da Associação Brasileira de Antropologia de 1954, os etnônimos não devem sofrer flexão de gênero ou número.

2 Para a área do Andirá a equipe contava com uma lista de moradores fornecida pela Funai. Ali, o coordenador técnico para a comunidade apenas apresentava a referida lista ao agente de saúde ou ao tuxaua, solicitando a confirmação, ou não, da condição de moradores entre os relacionados, e, se fosse o caso, a identificação de novos moradores ou de moradores ausentes da relação da Funai.

3 Sateré significa 'lagarta de fogo' e Mawé pode ser traduzido como 'papagaio falante'.

Referências Bibliográficas

BATISTA, M. P. O movimento indígena Sateré-Mawé do Rio Andirá. Manaus, 2001. (Mimeo.)

CARVALHO, J. A. M. Fecundidade e Mortalidade no Brasil - 1960/70. Relatório de Pesquisa. Belo Horizonte: Centro de Desenvolvimento e Planejamento Regional da Universidade Federal de Minas Gerais - Cedeplar, 1978.

FLOWERS, N. M. Crise e recuperação demográfica: os Xavánte de Pimentel Barbosa, Mato Grosso. In: SANTOS, R. V. G COIMBRA Jr., C. E. A. (Orgs.) Saúde dos Povos Indígenas. Rio de Janeiro: Ed. Fiocruz, 1994. p.213-242.

IBGE (INSTITUTO BRASILEIRO de GEOGRAFIA e ESTATÍSTICA). Censo Demográfico de 2000. Rio de Janeiro: IBGE, 2000.

LORENZ, S. S. Sateré-Mawé: os filhos do guaraná. São Paulo: Centro de Trabalho Indigenista, 1992.

PAgliaro, H. A Revolução Demográfica dos Povos Indígenas: a experiência dos Kaiabi do Parque Indígena do Xingu, Mato Grosso (1970-1999), 2002. Tese de Doutorado, São Paulo: Faculdade de Saúde Pública, Universidade de São Paulo. 
PAGLIARO, $\mathrm{H}$. et al. Comportamento demográfico dos índios Waurá no final do século XX. Proceedings of the XXIV General Population Conference, International Union for the Scientific Study of Population, p.1583-1594. Salvador, 2001.

PAGLIARO, H. et al. Índios Juruna (Yudjá): Comportamento Demográfico e Condições de Saúde. Parque Indígena do Xingu (1970-1999). In: VII CONGRESSO BRASILEIRO DE SAÚDE COLETIVA, Livro de Resumos, p.620, Brasília: Associação Brasileira de Pós-Graduação em Saúde Coletiva, 2003.

SOUZA, L. G. G SANTOS, R. V. Perfil demográfico da população indígena Xavánte de Sangradouro - Volta Grande, Mato Grosso (1993-1997), Brasil. Cadernos de Saúde Pública, 17:355-366, 2001.

UNIVERSIDADE FEDERAL DO AMAZONAS/ FUNDAÇÃO JOAQUIM NABUCO/FUNDAÇÃO ESTADUAL DE POLÍTICA INDIGENISTA DO AMAZONAS/ SECRETARIA DE EDUCAÇÃO DO ESTADO DO AMAZONAS. Relatório Técnico do Diagnóstico SócioDemográfico Participativo da População Sateré-Mawé das Áreas Indígenas AndiráMarau (Municípios de Barreirinha, Parintins e Maués) e Koatá-Laranjal (Município de Borba). Manaus: Universidade Federal do Amazonas/ Fundação Joaquim Nabuco/ Fundação Estadual de Política Indigenista/Secretaria de Educação do Estado do Amazonas, 2004. 
Perfil Demográfico e Socioeconômico das Pessoas que se Autodeclararam 'Indígenas' nos Censos Demográficos de 1991 e 2000

\section{Introdução}

Há uma notável carência de dados demográficos sobre as populações indígenas no Brasil. Em face da diversidade histórica, social e cultural dos povos indígenas, que somam mais de 200 etnias, falantes de 180 línguas diferentes, é praticamente nulo o que se conhece não somente acerca de sua estrutura populacional, como também dos níveis e padrões de fecundidade, mortalidade e migração, dentre outros aspectos da dinâmica demográfica (Silva, 1994; Ricardo, 1996; Azevedo, 2000; Santos G Coimbra Jr., 2003; Pagliaro et al., neste volume). Se os dados são escassos para os indígenas residentes em terras oficialmente reconhecidas pelo Estado brasileiro, são ainda menos conhecidas as características demográficas dos que vivem em áreas urbanas.

Nos últimos anos, nota-se a consolidação de diversas iniciativas voltadas para reverter o quadro de carência de dados demográficos sobre os povos indígenas no Brasil (ver Pagliaro et al., neste volume). Como exemplos podem ser citados o aumento no número de pesquisas em comunidades específicas e a consolidação de redes de pesquisadores voltados para o estudo da demografia indígena (como o Comitê de Demografia dos Povos Indígenas da Associação Brasileira de Estudos Populacionais - Abep). Outra iniciativa de grande relevância foi a inclusão da opção 'indígena' no quesito cor ou raça dos censos decenais a partir de 1991.

A metodologia para classificação da população indígena utilizada nos Censos Demográficos de 1991 e 2000 foi a autodeclaração, aplicando-se tanto aos indivíduos que nos anos dos censos habitavam as Terras Indígenas, quanto aos que viviam fora dessas áreas (IBGE, 1991, 2000, 2003).

O objetivo deste capítulo é apresentar um perfil demográfico e socioeconômico das pessoas que se declararam 'indígenas ${ }^{11}$ nos Censos de 1991 e 2000. De antemão, é importante frisar que, para fins deste trabalho, a categoria 'indígena' do IBGE (Instituto Brasileiro de Geografia e Estatística) não é tomada 
como sinônimo ou substituta de 'povos indígenas', de 'grupos indígenas' ou de 'população indígena', nos moldes que predomina na literatura antropológica especializada. Isso porque, por meio de seu sistema de coleta de informações, os censos vêm captando diferentes categorias sociológicas, duas das quais são as seguintes: povos indígenas enquanto totalidades sociológicas distintas, definidos pela convenção 169 da OIT (Organização Internacional do Trabalho), ou seja, povos que se diferenciam da coletividade nacional por seus usos, costumes e tradições; e, por outro lado, conjuntos de pessoas que se reconhecem como descendentes de índios (ou índio-descendente), mas que não sabem a que povo ou etnia pertenciam seus ancestrais indígenas. Ao traçar um perfil dos que se autodeclararam 'indígenas' nos censos, o intuito é contribuir para sistematizar e divulgar o que se constitui em uma importante base de dados pertinente a essa população, até agora muito pouco conhecida do ponto de vista demográfico, com objetivo de inclusive aprimorar a formulação do quesito cor/raça/etnia nos próximos censos e em outros levantamentos demográficos.

\section{Características demográficas}

Em 1991, 294 mil pessoas se declararam 'indígenas' (0,2\% da população total do país), enquanto que em 2000 o montante foi de $734 \mathrm{mil}(0,4 \%$ da população total). Portanto, um aspecto de grande relevância que emerge da comparação dos dois censos é o crescimento expressivo no número de indivíduos que se autodeclararam como 'indígenas'.

Houve não somente um aumento substancial no período, como também uma alteração na proporção dos 'indígenas' segundo tipo de situação de domicílio. Segundo o Censo de 1991, 24,1\% viviam em áreas urbanas e 75,9\% em área rural. Já em 2000 a distribuição foi de 52,2\% em área urbana e 47,8\% em área rural.

Tanto para o Censo Demográfico de 1991 quanto para o de 2000, há diferenças significativas na estrutura por sexo e idade dos 'indígenas' segundo situação do domicílio (Figuras 1, 2 e 3). Os residentes em áreas urbanas acompanham o padrão da composição por sexo e idade da população brasileira, que apresentou como característica baixa fecundidade e mortalidade, bem como uma razão de dependência baixa e idade mediana alta (Figura 2). Já para os 'indígenas' residentes na área rural, o comportamento piramidal é representativo de regimes populacionais com alta natalidade e mortalidade (Figura 3), que são também os padrões geralmente observados em estudos demográficos de povos indígenas específicos conduzidos por antropólogos e demógrafos (Early G Peters, 1990; Azevedo, 2000; Souza G Santos, 2001; Coimbra Jr. et al., 2002; Pagliaro, 2002; ver também Pagliaro, Santos et al., Azevedo, Teixeira e Brasil, neste volume). 
Figura 1 - Composição da população residente que se autodeclarou indigena wral pus sexo e idade. Brasil - 1991/2000

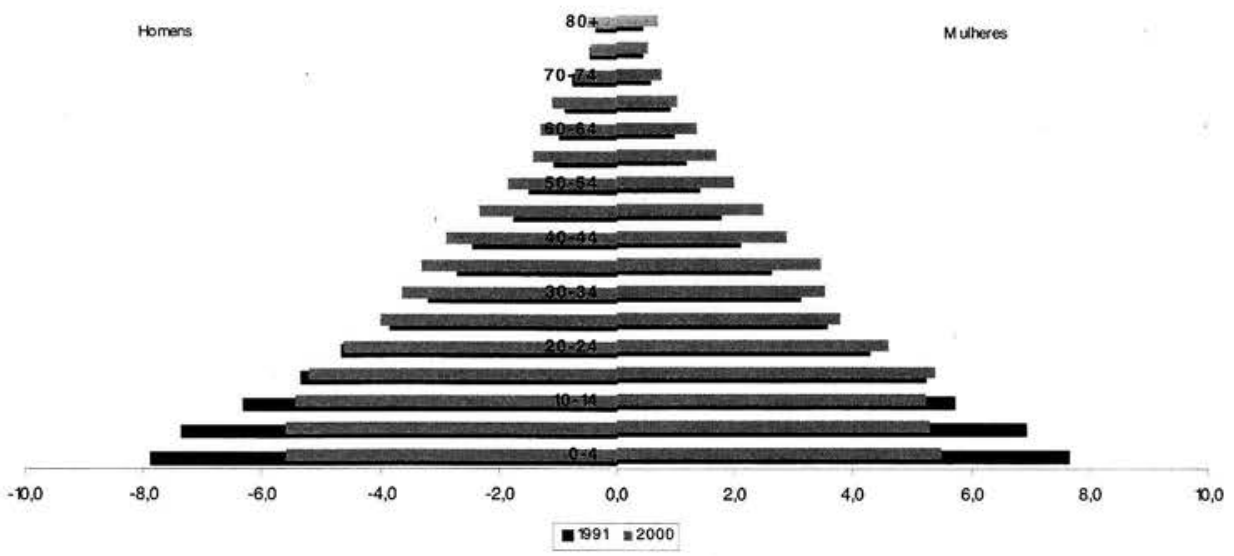

Figura 2 - Composição da população residente que se autodeclarou indígena urbana, por sexo e idade. Brasil - 1991/2000

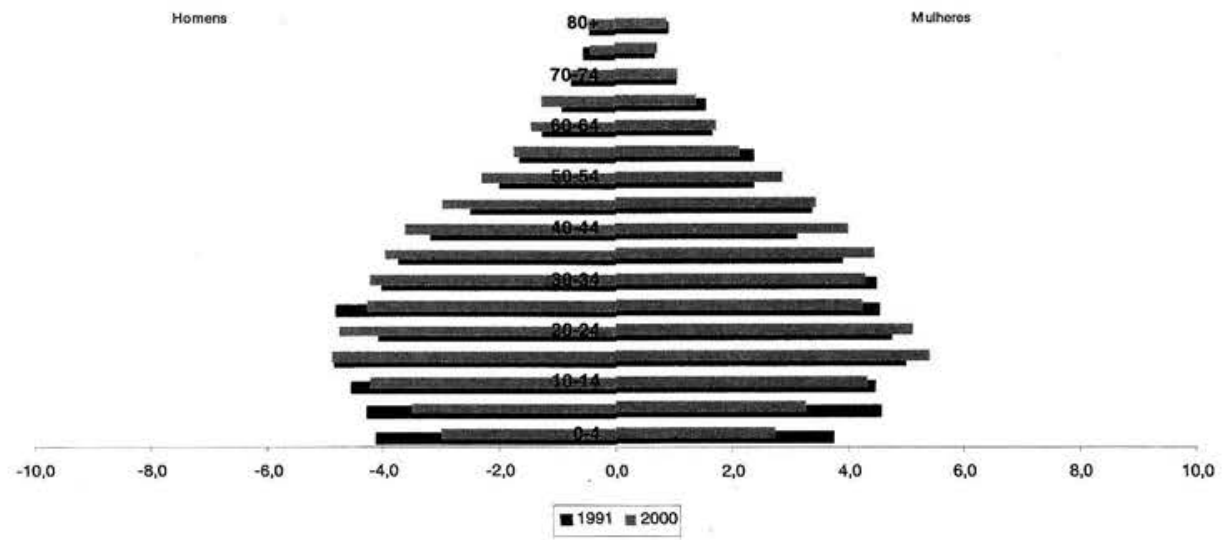

Figura 3 - Composição da população residente que se autodeclarou indígena rural, por sexo e idade. Brasil - 1991/2000

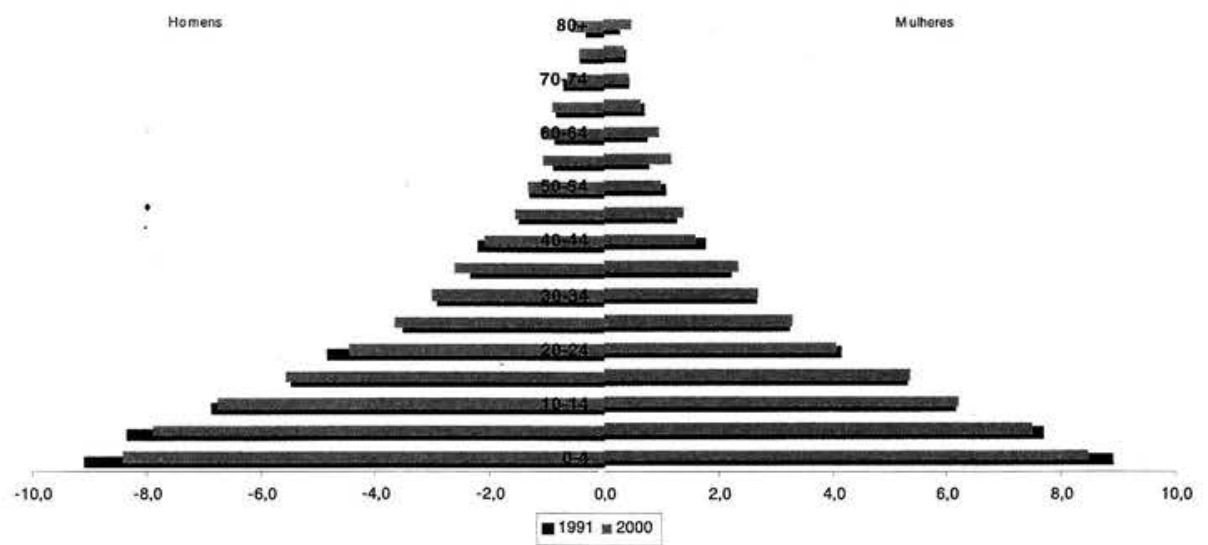


A idade mediana dos 'indígenas' revelada pelo Censo Demográfico 2000 foi 23,2 anos (22,9 anos para homens e 23,5 anos para mulheres), valor superior ao detectado pelo Censo Demográfico de 1991, que foi de 18,4 anos (18,2 anos para homens e 18,6 anos para mulheres). É particularmente expressiva a diferença das medianas de idade entre 'indígenas' rurais e urbanos tanto em 1991 (16,2 vs. 28,2 anos) como em 2000 (16,8 vs. 30,1 anos).

Segundo o Censo Demográfico de 1991, para os 'indígenas', as proporções de indivíduos de 0 a 14 anos de idade e de adultos ( 15 a 64 anos de idade) eram semelhantes ( $41,8 \%$ e $53,4 \%$, respectivamente). Já os idosos (65 anos ou mais) representavam somente $4,7 \%$ da população total. Em 2000, a participação relativa do contingente de crianças e adolescentes declinou e a contribuição dos adultos cresceu (Figura 4). Assim, as proporções de crianças e adolescentes ( 0 a 14 anos de idade) e de adultos (15 a 64 anos de idade) passaram a ser de $32,6 \%$ e $61,6 \%$, respectivamente. Considerando situação de moradia, a proporção de crianças e adolescentes na área rural $(45,2 \%)$ foi duas vezes maior que na área urbana $(21,1 \%)$. Para os com 65 anos ou mais, o padrão mostrou-se o inverso, com uma maior proporção $(7,0 \%)$ na área urbana, com a rural apresentando somente 4,4\%.

Figura 4 - Proporção da população que se autodeclarou indígena por situação do domicílio, segundo os grupos de idade. Brasil - 2000

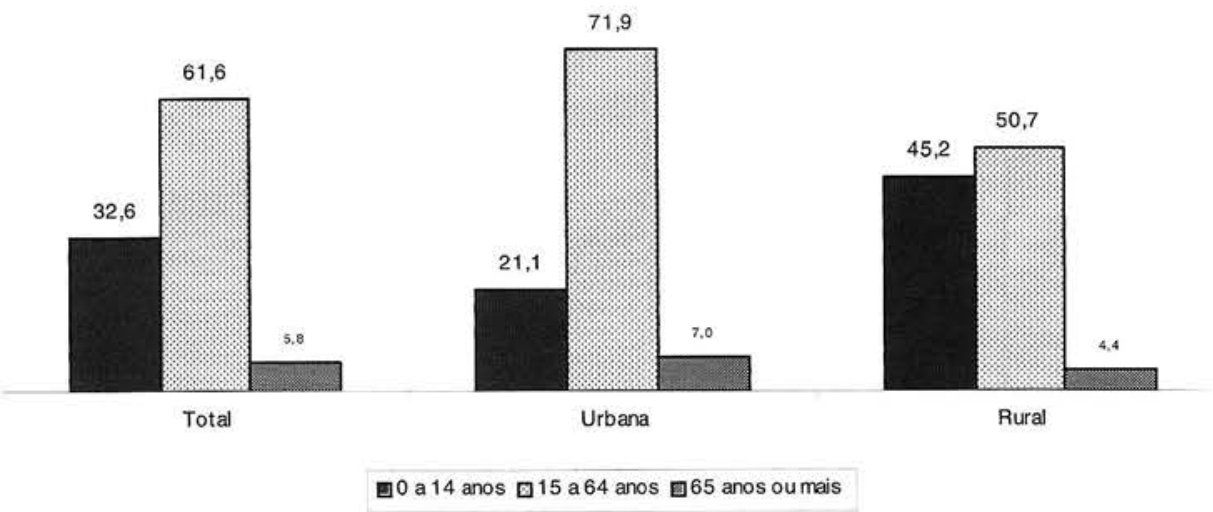

Mesmo que tenha decrescido o número de jovens segundo o Censo Demográfico 2000 se comparado ao de 1991, um aspecto que permaneceu foi que os 'indígenas' conformam uma população bastante jovem. Assim, segundo os resultados de 2000 , mais da metade (52\%) tinha até 24 anos de idade (41\% na área urbana e $65 \%$ na área rural).

Segundo os dados do Censo Demográfico 2000, a proporção de 'indígenas' com até 24 anos tende a ser menor nas regiões Sul e Sudeste, e de certo modo 
também na Nordeste. As regiões Centro-Oeste e Norte concentram um contingente indígena comparativamente mais jovem.

Essas diferenças marcantes entre o perfil etário da população 'indígena' rural e urbana provavelmente se devem justamente à diferença entre os perfis demográficos dos povos indígenas residentes nas Terras Indígenas (considerados pelos censos como rurais) e os índios descendentes das áreas urbanas, já com um perfil demográfico mais próximo da população brasileira em geral.

No Brasil, a tendência histórica quanto às razões de sexo é de predominância feminina para a população total. Quanto à situação de domicílio, esse padrão se verifica também para a área urbana, com uma inversão no contexto rural, no qual há mais homens do que mulheres. Para os 'indígenas', o Censo Demográfico 2000 revelou um equilíbrio entre homens e mulheres (Figura 5). No tocante à área urbana e rural, observa-se um quadro semelhante àquele da população brasileira como um todo.

Figura 5 - Razão de sexo da população que se autodeclarou 'indígena', segundo a situação do domicílio. Brasil - 1991-2000
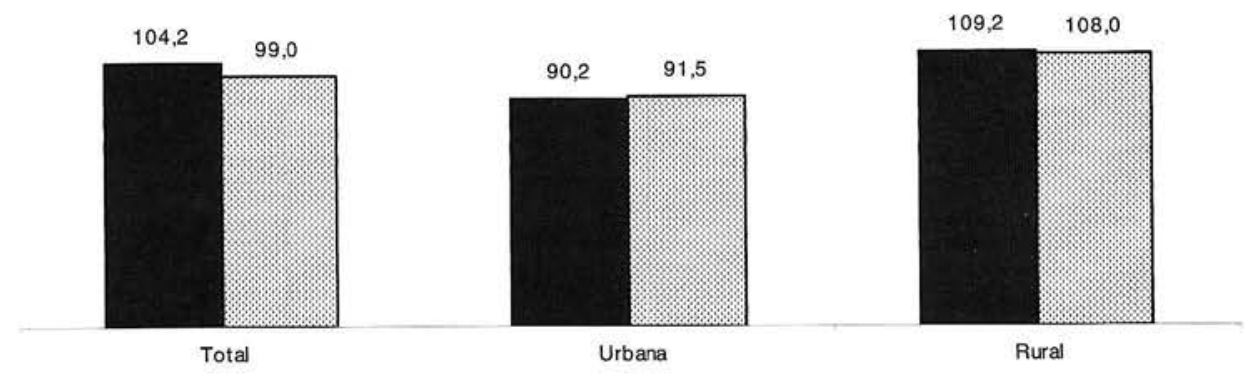

घ1991 뭄 2000

Conforme já referido, os resultados do Censo Demográfico 2000 revelaram que o contingente 'indígena' apresentou um crescimento significativo em relação ao Censo Demográfico de 1991, da ordem de 10,8\% ao ano. O aumento foi mais significativo na área urbana (20,8\% ao ano) que na rural (5,2\% ao ano) (Figura 6). A região geográfica que apresentou o maior crescimento foi a Sudeste $(20,5 \%$ ao ano); o menor ficou com a Norte ( $6,2 \%$ ao ano). Isto talvez ocorra graças ao aumento de autodeclaração de índio-descendentes nas áreas urbanas das regiões Sudeste, Centro-Oeste e Nordeste, principalmente. Nas áreas rurais, os autodeclarados 'indígenas' são pertencentes aos povos; logo, não deve ter havido um grande aumento na autodeclaração, mas sim um aumento populacional por causa do crescimento vegetativo destes povos. Não há diferenciais acentuados nas taxas médias 
geométricas de crescimento anual de homens e mulheres, com ambos os sexos acompanhando a tendência da população 'indígena' total.

Figura 6 - Taxa média geométrica de crescimento anual da população residente que se autodeclarou indígena por situação do domicílio, segundo as Grandes Regiões. Brasil - 1991-2000

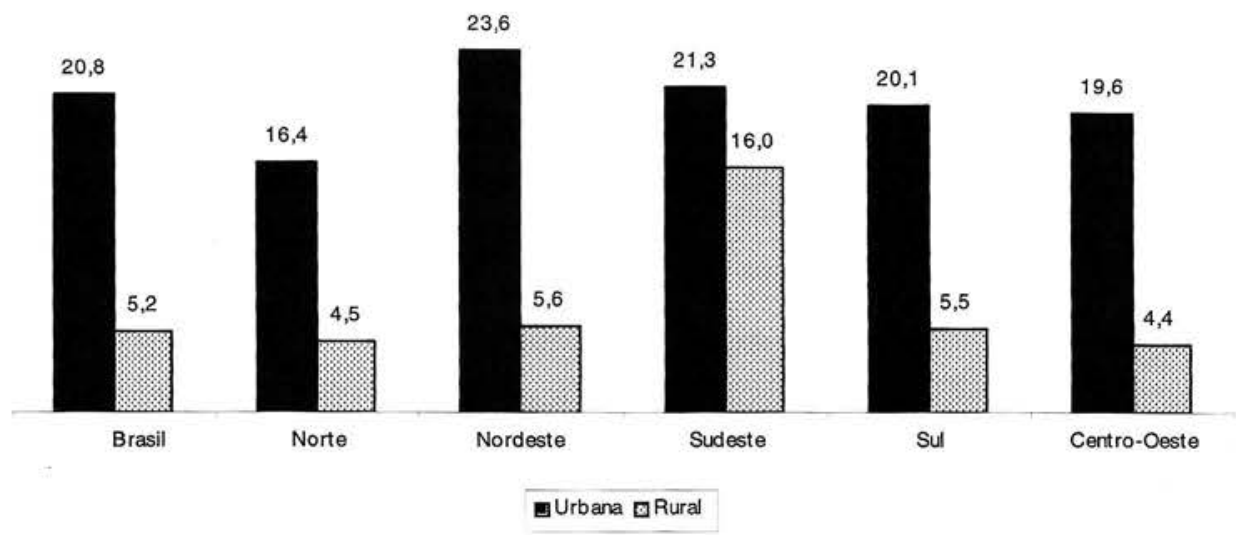

Componentes da dinâmica demográfica

As informações provenientes do Censo Demográfico de 1991 não possibilitaram boas estimativas do nível de fecundidade das mulheres que se autodeclararam como 'indígenas'. Já para o Censo Demográfico 2000, as informações foram mais robustas, o que tornou possível calcular a taxa de fecundidade total das 'indígenas' de 15 a 49 anos, que foi de 3,9 filhos por mulher (2,7 filhos por mulher para a área urbana e 6,0 filhos por mulher para a área rural).

Quanto a outros parâmetros relativos ao comportamento reprodutivo das mulheres, calculados com as informações relativas a 2000, a taxa bruta de natalidade dos 'indígenas' foi de 32,7 por mil, com diferenças importantes entre as áreas urbanas e rurais (25,4 e 41, 9 por mil, respectivamente). A taxa geral de fecundidade em 2000 era de 12,5, com o valor para a área rural $(20,2)$ mais que o dobro daquele da área urbana $(8,2)$.

Quanto aos resultados relativos à migração, em 2000 foram recenseadas 103.483 'indígenas' residentes em Unidades da Federação diferentes daquelas onde nasceram. Foi no Sudeste, região na qual houve o maior incremento de 'indígenas', que se verificou também o mais elevado fluxo migratório, sobretudo para Rio de Janeiro e para São Paulo (Figura 7). Tal observação levanta a possibilidade de que o aumento das pessoas que se autodeclararam 'indígenas' nesses e em outros estados, 
de 1991 para 2000, pode estar associado a eventos migratórios, fato que requer melhor investigação.

Figura 7 - Saldo migratório da população que se autodeclarou indígena, utilizando a informação de lugar de nascimento, segundo as Unidades da Federação. Brasil - 2000

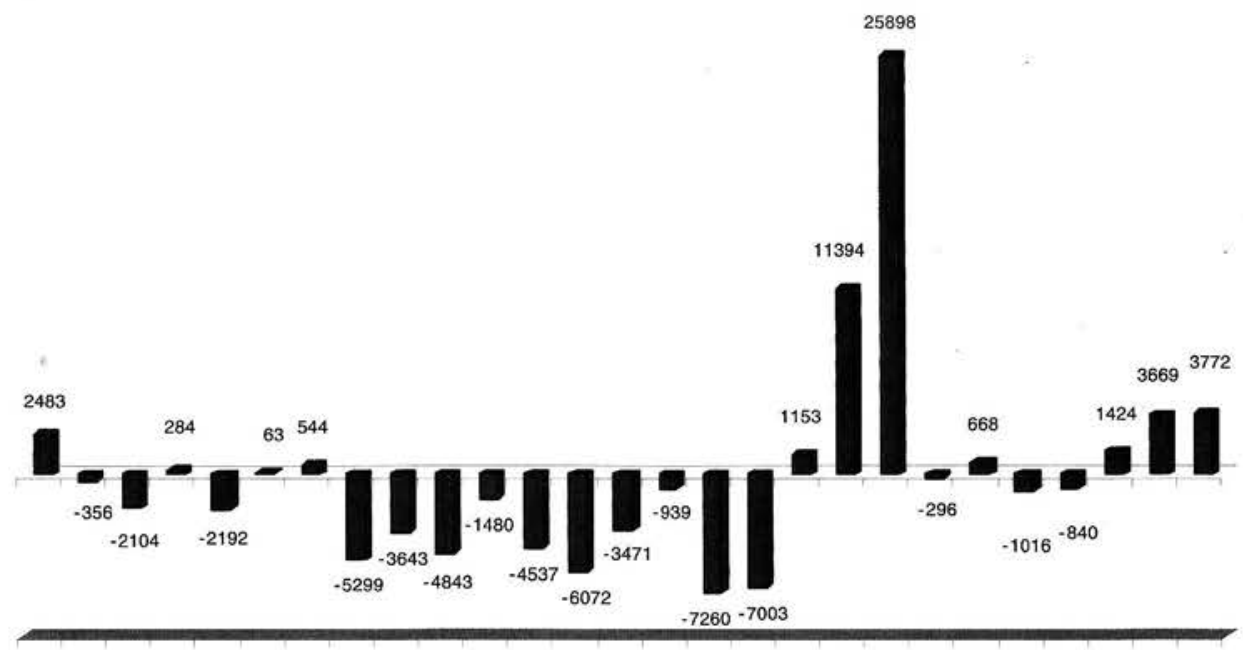

RO AC AM RR PA AP TO MA PI CE RN PB PE AL SE BA MG ES RJ SP PR SC RS MS MT GO DF

\section{Características sociais e econômicas}

O contingente de 'indígenas' apresentou mudanças em termos educacionais na última década. A taxa de alfabetização ${ }^{2}$ dos 'indígenas' era de 49,2\% segundo o Censo Demográfico de 1991 (75,2\% na área urbana e 37,6\% na área rural), aumentando para 73,9\% segundo o Censo Demográfico de 2000 (86,2\% na área urbana e 54,5\% na área rural). Por conseguinte, a taxa de analfabetismo permanece alta nas áreas rurais, embora tenha diminuído no período. Porém, isso não reflete uma melhora ou piora das condições de vida, uma vez que, como já foi mencionado anteriormente, a população 'indígena' rural pertence aos povos habitantes das Terras Indígenas, è seria necessária uma análise antropológica para considerar a escolarização como um indicador de melhoria das condições de vida desta população.

A taxa de escolarização ${ }^{3}$ dos 'indígenas' de 5 a 24 anos de idade revelada pelo Censo Demográfico de 2000 foi $43,8 \%$, com um crescimento significativo em relação a $1991(29,6 \%)$. Para as crianças de cinco a nove anos de idade, a taxa alcançou $60,4 \%$ (83,6\% para a área urbana e de apenas $49,2 \%$ para a área rural) (Figuras 8 e 9). Para este subgrupo, a taxa de escolarização em 2000 dobrou em 
relação a 1991. Com relação ao grupo de 10 a 14 anos de idade, observou-se que os 'indígenas' atingiram proporções superiores a $80 \%$.

Figura 8 - Taxa de escolarização das pessoas que se autodeclaram indígenas de 5 a 24 anos de idade, segundo os grupos de idade. Brasil 1991-2000

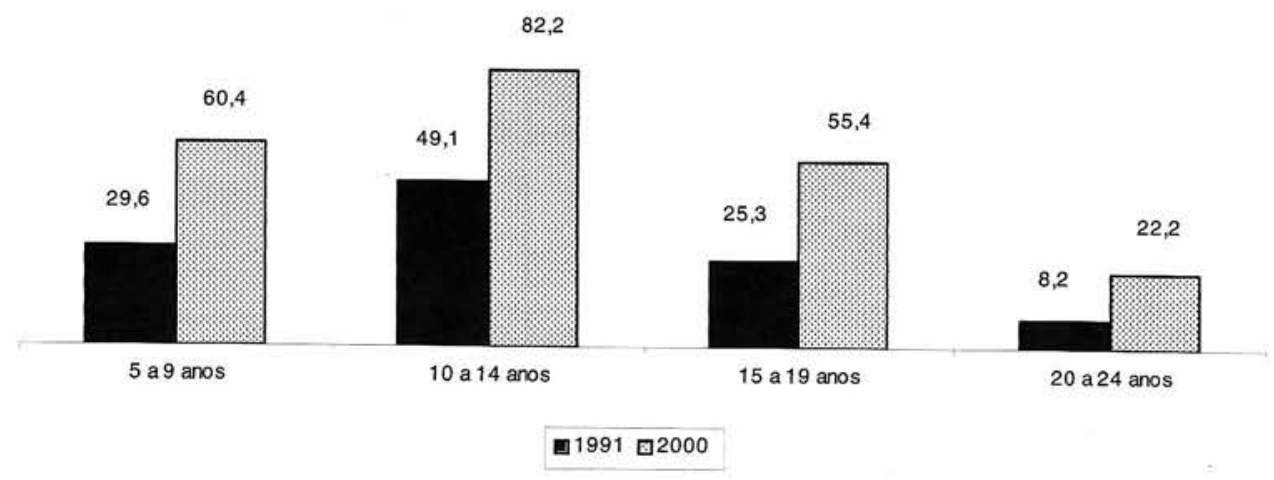

Figura 9 - Taxa de escolarização das pessoas que se autodeclaram indígenas de 5 a 24 anos de idade por situação do domicílio, segundo os grupos de idade. Brasil - 2000
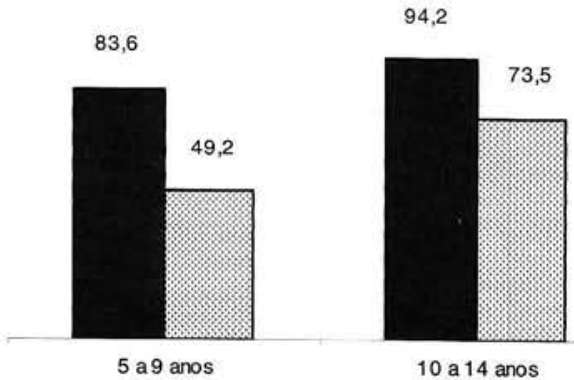

10 a 14 anos

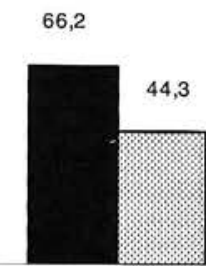

15 a 19 anos

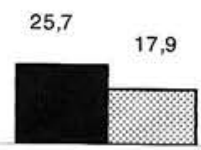

20 a 24 anos

巴Urbana 回Rural

Os avanços na média de escolaridade dos 'indígenas' foram significativos na última década, com um incremento de 95,8\%. Em 1991, os 'indígenas' de 10 anos ou mais de idade detinham uma média de 2,0 anos de estudo, passando para 3,9 anos em 2000. No período 1991-2000, a área urbana aumentou de 4,0 para 5,0 anos de estudo em média, tendo o maior aumento ocorrido na área rural (de 1,2 para 2,0 anos de estudo) (Figura 10). 
Figura 10 - Média de anos de estudo das pessoas que se autodeclaram indígenas de 10 anos ou mais de idade por situação do domicílio, segundo os grupos de idade. Brasil -2000

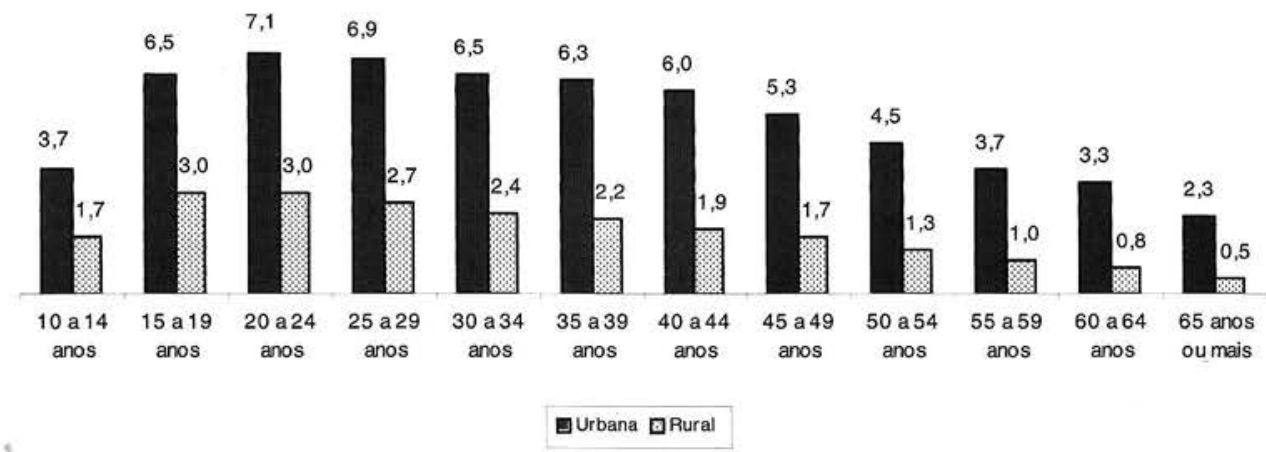

Considerações no âmbito geográfico

As características demográficas, sociais e econômicas dos 'indígenas' são distintas quando analisadas pela localização geográfica. Em 2000, a região Norte detinha o maior percentual, com 1,6\% de 'indígenas' em relação à população total da região. Os estados de Roraima e Amazonas contabilizaram 8,7\% e 4,0\%, respectivamente, que correspondem às proporções mais elevadas de 'indígenas' dentre os estados brasileiros. A região Sudeste detinha a menor proporção.

Figura 11 - Taxa de urbanização da população total e taxa de analfabetismo das pessoas que se autodeclaram indígenas de 15 anos ou mais de idade, segundo as Unidades da Federação. Brasil - 2000

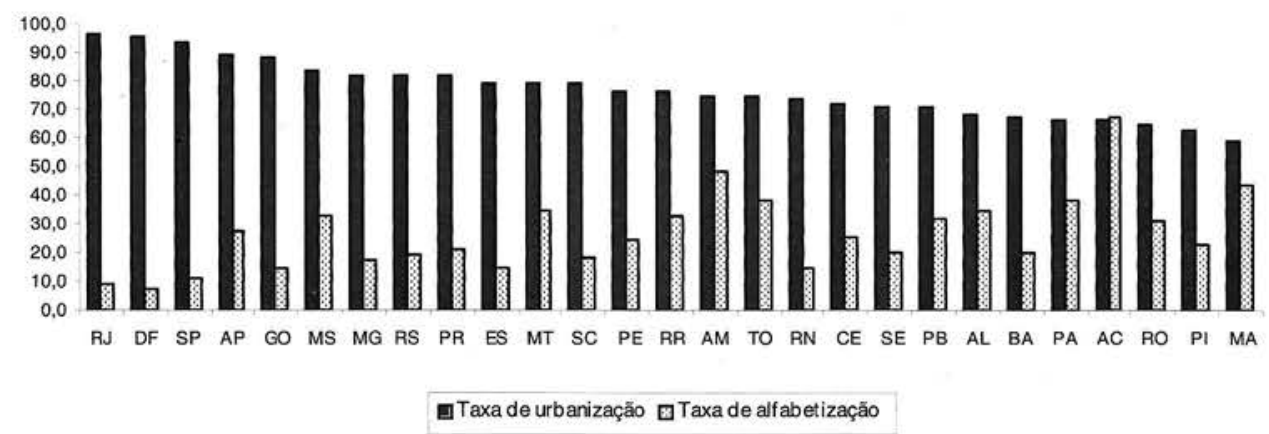


Quanto ao nível educacional, 43,2\% dos 'indígenas' de 15 anos ou mais são analfabetos segundo o Censo Demográfico de 2000 (Figura 11). O Acre apresenta a maior proporção $(66,9 \%)$ dentre todos os estados. Os níveis de analfabetismo de um modo geral são bem elevados, independentemente de localização geográfica, com raras exceções, como Distrito Federal $(7,0 \%)$ e Rio de Janeiro $(9,4 \%)$. Esses são os estados com a maior proporção de população urbana do país. No Brasil, verificase que, quanto maior é a proporção de população urbana, menor a taxa de analfabetismo, o que aponta para uma correlação entre alfabetização e urbanização.

\section{Considerações finais}

A comparação entre os Censos Demográficos de 1991 e 2000 impõe desafios interpretativos de grande magnitude no tocante aos indivíduos que se autodeclararam 'indígenas'. Como vimos nesse trabalho, os totais de 'indígenas' foram de, respectivamente, 294 e 734 mil, vale dizer, um crescimento de mais de $100 \%$ em menos de uma década. As razões que explicam o notável incremento são desconhecidas e demandarão um intenso esforço de análise nos próximos anos. Azevedo G Ricardo (2002) sugerem várias possibilidades como, por exemplo, crescimento demográfico real dos povos indígenas, aumento da proporção de índios urbanizados que optaram pela identificação 'indígena' e que se classificaram como 'pardos' em censos anteriores e ampliação do contingente de pessoas que se classificaram genericamente como 'indígenas', ainda que não se identificando com etnias específicas.

A despeito das dificuldades interpretativas relativas à comparação entre os censos, mediante as informações do Censo Demográfico 2000 surgem caracterizações relevantes sobre os 'indígenas'. Assim, apresentam um perfil demográfico que os diferenciam da população brasileira em geral, como, por exemplo, no que se relaciona à distribuição rural-urbano, composição etária, padrões de fecundidade e escolarização. Além disso, há marcantes diferenças entre os 'indígenas' quanto à situação do domicílio, com aqueles residentes em áreas rurais apresentando características como composição etária predominantemente jovem, elevados níveis de fecundidade e características socioeconômicas diversas (baixos níveis de escolaridade) mais próximas daquele perfil delineado em pesquisas realizadas em comunidades indígenas específicas (Early G Peters, 1990; Azevedo, 2000; Souza G Santos, 2001; Coimbra Jr. et al., 2002; Pagliaro, 2002; ver também Pagliaro, Santos et al., Teixeira e Azevedo, neste volume).

A opinião de muitos especialistas é que a formulação do quesito sobre raça ou cor em censos futuros a serem realizados no Brasil precisa de ser aperfeiçoada. Em alguns países da América Latina, além da autodeclaração, outros critérios são utilizados para a classificação, tais como o idioma ou língua falada e a localização 
geográfica (ver McSweeney $G$ Arps, 2005). Nos censos brasileiros, predomina um conceito de 'índio genérico', haja vista que não são colocadas à disposição informações sobre grupos étnicos específicos (Xavánte, Kayapó, Yanomami etc.). Há pelo menos duas possibilidades a serem implementadas no futuro. Uma primeira seria o refinamento do quesito cor ou raça nos censos nacionais no que tange aos 'indígenas', incorporando critérios como aqueles que têm sido utilizados em outros países. Uma segunda seria a realização de levantamento de população, em escala nacional, estritamente voltado para os povos indígenas, por intermédio do qual informações com um maior grau de detalhamento poderiam ser coletadas.

\section{Agradecimentos}

A técnica Luciana Martins Gomes participou da geração das informações, utilizando o software Redatam.

1 A palavra 'indígena' neste trabalho identifica as pessoas que se autodeclararam como tal nos censos demográficos, independentemente de serem pertencentes a um povo específico ou não.

2 Por taxa de alfabetização entende-se a porcentagem de pessoas alfabetizadas de um ğrupo etário em relação ao total de pessoas do mesmo grupo etário. Para fins do Censo Demográfico, "pessoa alfabetizada" é aquela capaz de ler e escrever pelo menos um bilhete simples.

3 Por taxa de escolarização entende-se a porcentagem de pessoas de uma determinada faixa etária que freqüenta escola em relação ao total de pessoas da mesma faixa etária.

Referências Bibliográficas

AZEVEDO, M. Censos demográficos e "os índios": dificuldades para reconhecer e contar. In: RICARDO, C. A. (Org.) Povos Indígenas no Brasil 1996/2000. São Paulo: Instituto Socioambiental, 2000. p.79-83.

AZEVEDO, M. M. G RICARDO, F. Censo 2000 do IBGE Revela Contingente "Indígena" Pouco Conhecido. http://www.socioambiental.org, acessado em 14 de abril de 2005. 
COIMBRA Jr., C. E. A. et al. The Xavánte in Transition: health, ecology and bioanthropology in Central Brazil. Ann Arbor: University of Michigan Press, 2002.

EARLY, J. D. G PETERS, J. F. The Population Dynamics of the Mucajai Yanomama. New York: Academic Press, 1990.

IBGE (INSTITUTO BRASILEIRO DE GEOGRAFIA E ESTATÍSTICA) Censo Demográfico 1991: Manual do Recenseador (CD-ROM - 1.09). Rio de Janeiro: IBGE, 1991.

IBGE (INSTITUTO BRASILEIRO DE GEOGRAFIA E ESTATÍsTICA) Censo Demográfico 2000: Manual do Recenseador (CD-ROM - 1.09). Rio de Janeiro: IBGE, 2000.

IBGE (INSTITUTO BRASILEIRO DE GEOGRAFIA E ESTATÍsTICA) Censo Demográfico 2000: Metodologia do Censo Demográfico 2000. Série Relatórios Metodológicos, vol. 25. Rio de Janeiro: IBGE, 2003.

McSWEENEY, K. G ARPS, S. A "demographic turnaround": the rapid growth of indigenous populations in lowland Latin America. Latin American Research Review, 40:3-29, 2005.

PAGLIARO, H. A Revolução Demográfica dos Povos Indígenas: a experiência dos Kaiabi do Parque Indígena do Xingu, Mato Grosso (1970-1999), 2002. Tese de Doutorado, São Paulo: Faculdade de Saúde Pública, Universidade de São Paulo.

RICARDO, C. A. A sociodiversidade nativa contemporânea no Brasil. In: RICARDO, C. A. (Org.) Povos Indígenas no Brasil 1991/1995. São Paulo: Instituto Socioambiental, 1996. p.i-xii.

SANTOS, R. V. G COIMBRA Jr., C. E. A. Cenários e tendências da saúde e da epidemiologia dos povos indígenas no Brasil. In: COIMBRA Jr., C. E. A., SANTOS, R. V. G ESCOBAR, A. L. (Orgs.) Epidemiologia e Saúde dos Povos Indígenas no Brasil . Rio de Janeiro: Ed. Fiocruz/Associação Brasileira de Saúde Coletiva - Abrasco, 2003. p.13-47.

SILVA, M. F. A demografia e os povos indígenas no Brasil. Revista Brasileira de Estudos de População, 11:261-264, 1994.

SOUZA, L. G. G SANTOS, R. V. Perfil demográfico da população indígena Xavánte de Sangradouro - Volta Grande, Mato Grosso (1993-1997), Brasil. Cadernos de Saúde Pública, 17:355-366, 2001. 


\section{A Dinâmica Demográfica dos Mucajaí Yanomami: uma entrevista com John Early}

\section{Apresentação}

Durante o seminário 'Demografia dos Povos Indígenas no Brasil', realizado na Universidade Federal de São Paulo em novembro de 2003, promovido pelo Comitê de Demografia dos Povos Indígenas, da Associação Brasileira de Estudos Populacionais (Abep), contou-se com a presença do Dr. John D. Early, antropólogo e demógrafo, professor aposentado do Departamento de Antropologia da Florida Atlantic University, Flórida, Estados Unidos.

Juntamente com John Peters, John Early é autor de dois importantes livros sobre a demografia dos Yanomami, a saber: The Population Dynamics of the Mucajai Yanomama (Academic Press, 1990) e The Xilixana Yanomami of the Amazon (University Press of Florida, 2000). Esses livros, publicados nos Estados Unidos, infelizmente não foram traduzidos para o português. Além dessas duas obras, John Early escreveu trabalhos em que analisou variados aspectos da demografia de povos nativos na Guatemala e nas Filipinas.

No seminário em São Paulo, John Early apresentou um panorama geral de seus estudos demográficos sobre os Yanomami. Tais investigações estão seguramente entre as mais detalhadas e sofisticadas - para não mencionar o período de tempo abrangido - análises existentes sobre a demografia de povos indígenas no Brasil.

Ao receber alguns meses depois o trabalho de Early, tomou-se a iniciativa de consultá-lo quanto à possibilidade de transformar seu texto em uma entrevista. A motivação não foi somente o tom pessoal que John imprimiu em vários trechos, mas também a tentativa de recuperar a atmosfera de intenso e instigante diálogo intelectual que os participantes mantiveram com Early durante os dias do seminário. A sugestão foi acolhida com entusiasmo pelo antropólogo. Passou-se, então, à tarefa de rearranjar o texto original de Early em uma estrutura de pergunta-resposta.

Espera-se que os leitores aproveitem tanto quanto os participantes, que tiveram a oportunidade de interagir com John Early durante o seminário, o conteúdo da entrevista desse importante pesquisador no campo da demografia dos povos indígenas no Brasil. 


\section{Como surgiu a idéia de desenvolver a pesquisa sobre a demografia dos Yanomami?}

John Peters e eu começamos a trabalhar juntos em 1983 por meio de uma troca de cartas. Inicialmente, John era missionário. Em 1957, ele subiu o rio Mucajaí e estabeleceu o primeiro contato permanente com os Yanomami que então viviam na porção média desse rio. No ano seguinte, ele ajudou a estabelecer um posto missionário no local, sendo acompanhado pela noiva, Lorraine, que tinha formação em enfermagem. Com os quatro filhos, eles viveram entre os Yanomami durante nove anos, de 1959 a 1967, quando voltaram para o Canadá. John obteve o doutorado (Ph.D.) em antropologia nos Estados Unidos e começou a lecionar sociologia na Universidade Wilfrid Laurier, no Canadá. Nos anos posteriores, ele fez seguidas viagens aos Yanomami para renovar velhos laços de amizade.

Eu fiz minha tese de doutorado entre os Maia do México, como membro do projeto de pesquisa Harvard-Chiapas. Depois trabalhei muitos anos entre os Maia da Guatemala, seja como pesquisador ou como agente de desenvolvimento comunitário, em programas de alfabetização, saúde pública, crédito e cooperativas agrícolas. Em 1982, publiquei um livro sobre a dinâmica populacional dos Maia guatemaltecos (Early, 1982, 2000). Eu pretendia retornar à Guatemala para dar continuidade à pesquisa, mas não pude fazê-lo por causa de impedimentos de ordem civil e eclesiástica. Foi nessa época que teve início minha colaboração com Peters. Começamos a elaborar um banco de dados demográficos e etnográficos com base nas informaçôes coletadas por Peters junto aos Yanomami.

Pela sua experiência, como você percebe as potenciais contribuiçôes entre antropólogos e demógrafos em estudos sobre os povos indígenas?

A tendência tem sido antropólogos e demógrafos trabalharem isoladamente. Em casos extremos, alguns antropólogos discutiram dinâmica populacional de forma especulativa, sem um tratamento demográfico mínimo que pudesse eliminar o caráter especulativo da análise. A discussão sobre o infanticídio Yanomami na literatura antropológica é um bom exemplo disso. Já pelo lado da demografia, os casos extremos resultaram em demógrafos apresentando índices quantitativos, mas incapazes de fornecer explicações convincentes para esses números. Por exemplo, sem a compreensão do sistema de parentesco Yanomami de primos cruzados, torna-se impossível entender os padrôes de casamento e a migração entre aldeias. Os problemas intelectuais exigem os 
conhecimentos das duas disciplinas e o melhor trabalho é realizado quando a mesma pessoa, ou um grupo trabalhando em estreita proximidade, detém os conhecimentos de ambas.

\section{E sobre a participação de missionários?}

Uma parte crucial de nosso estudo foi o fato de termos trabalhado com missionários. Eles possuíam duas características essenciais para o sucesso da pesquisa: estavam permanentemente com os Yanomami e falavam a língua deles. Cientistas sociais, em geral, trabalham em instituições acadêmicas ou na burocracia governamental, e muitas vezes só têm condições de realizar pesquisas de campo relativamente curtas. No caso dos povos indígenas, e em muitas outras situaçōes, análises demográficas substanciais em geral requerem dados coletados ao longo de um maior período de tempo, como vários anos. Conseqüentemente, as condições de trabalho dos cientistas sociais geralmente não são favoráveis à coleta de dados demográficos de alta qualidade. Apesar disso, os cientistas sociais costumam ser céticos quanto ao trabalho em cooperação com missionários. Mas há vários tipos de missionários. Eles se distribuem num espectro que vai desde o fanatismo religioso até o humanismo calcado na religião. Nos três grupos em que fiz pesquisa, estive envolvido com instituiçôes religiosas que tinham presença constante em campo (entre os Maia, por exemplo); ou trabalhei diretamente com missionários, a saber, John Peters e aqueles que o sucederam (entre os Yanomami) e Thomas Headland (entre os Agta, nas Filipinas). Para o bem da pesquisa, é preciso superar alguns preconceitos profissionais e religiosos.

Fale-nos sobre a base de dados que você e Peters geraram.

Fizemos um registro demográfico para cada indivíduo que viveu no Mucajaí no período de tempo abrangido pela pesquisa. A ficha de cada um desses indivíduos contém as seguintes informações: a) nascimento: ano, mês, dia e local de nascimento, nome do pai ou de cada homem considerado pai (no caso de haver mais de um) e nome da mãe; b) morte: ano, mês, dia, local e causa da morte; c) imigração: ano, motivo da imigração, local de origem e de destino (em que aldeia fixou residência); d) emigração: ano, motivo da emigração, local de origem e de destino. Registramos também informaçōes sobre abortos provocados e morte fetal. Para os dados não quantificáveis foram criados alguns códigos. Toda essa massa de informação foi então compilada em uma base de dados computadorizada. A dificuldade de construir um banco desse tipo está justamente na obtenção de informações detalhadas sobre cada indivíduo. Os 
missionários forneceram esses dados, coletados desde 1968 até o final de 1995. Peters verificou as informaçōes voltando sete vezes a campo.

\section{Especificamente, como foi estruturada a base?}

A base de dados foi construída, como disse, utilizando registros individuais dos Yanomami. Embora seja uma tarefa demorada, compilar a história demográfica de cada indivíduo permite muito mais possibilidades de análise do que teríamos caso utilizássemos dados previamente agrupados. Há muito material coletado por organizações governamentais ou privadas, com finalidades administrativas, por exemplo. Os censos nacionais são o maior exemplo. No entanto, mesmo se os dados do censo fossem compilados em registros individuais - e muitos não o são -, eles são sempre sintetizados para fins de publicação. A Comissão de População das Nações Unidas sugeriu alguns formatos para esses resumos, mas em muitos deles há distorçōes subjacentes. Por exemplo, eles tomam por base a estrutura das sociedades industriais, que não é necessariamente apropriada para lidar com sociedades não industriais e com setores não industriais - rurais e indígenas - das sociedades industriais (Early, 1982:170-180; 2000:205-215). Também podem ocorrer problemas de comparabilidade dos dados, quando as diferentes agências adotam formatos sugeridos, porém, distintos. Já quando uma base de dados é montada valendose da história demográfica de cada indivíduo, é possível arranjar os dados de quase todas as maneiras indicadas pelas informações históricas e etnográficas ou pelas teorias demográficas.

\section{O que você apontaria como a maior dificuldade metodológica enfrentada no estudo?}

O problema mais difícil da pesquisa foi obter as datas para compor a história demográfica de cada um dos indivíduos. Utilizar como parâmetro a contagem de anos e a idade que os indivíduos tinham quando passaram por determinado evento demográfico é uma necessidade de qualquer análise demográfica mais profunda. Sem isso, é impossível avançar para além de uma análise elementar, baseada em taxas brutas. É um problema sério determinar a idade das pessoas em populações indígenas. Geralmente não são letradas, possuem um sistema de contagem básico e não consideram a precisão de datas e idades como algo relevante. Para nós, a data de nascimento é a mais importante, pois sem ela não se pode determinar a idade em que outros eventos demográficos acontecem. Em nossa pesquisa, isso era um problema sempre que se tratava de todas as pessoas que nasceram, morreram ou migraram durante o período pré-contato. 
Era um problema inclusive quando se tratava de mortes, imigrações ou emigrações que ocorreram após o contato, mas de pessoas que nasceram antes dele.

\section{Como vocês resolveram esse problema?}

Nós elaboramos histórias de vida reprodutiva de cada mulher. Os dados iniciais para construirmos tais histórias foram obtidos pela genealogia dos nascimentos até 1959, e pelos registros de nascimento posteriores a 1958. Isso nos deu, para cada mulher prolífica, uma lista preliminar de seus filhos por ordem de nascimento. A esse material, acrescentamos todas as datas de nascimento conhecidas, assim como as idades das mães à época dos nascimentos (posteriores a 1958). Tais dados serviram de base. Informações adicionais foram deduzidas dos padrões presentes nos 'relógios' biológico e cultural que regulam início, duração e término do período reprodutivo. A estratégia principal foi desenvolver critérios que se valessem daqueles dados das histórias de vida reprodutiva que sabíamos ser confiáveis. Então, nós os utilizamos para reconstruir a população de antes do contato. $O$ uso de histórias de vida reprodutiva para esse fim pressupóe que a estrutura de fecundidade tenha permanecido relativamente constante ao longo de todo o período considerado para a derivação e aplicação dos critérios. Isso foi verificado mediante investigação etnográfica; foi verificado, também, pela constatação da grande proximidade entre os índices de fecundidade gerados pela análise da coorte passada (ou retrospectiva) e da coorte atual de mulheres (Early $G$ Peters, 1990:51).

\section{$E$ as datas de nascimento, como foram calculadas?}

As datas de nascimento de que não dispúnhamos e que, portanto, precisavam de ser estimadas, foram derivadas da seguinte forma: tomamos uma data de nascimento conhecida na mesma história (isto é, de uma mesma mulher) e fizemos um cálculo levando em conta a extensão/duração média do intervalo entre os nascimentos. Usamos três variações do mesmo método para determinar daţas de nascimento do período anterior ao contato. De uma história de vida reprodutiva cuja data de nascimento de pelo menos um sibling (irmão ou irmâ) conhecíamos, subtraiu-se essa data do tempo médio de intervalo entre os nascimentos para obtermos a data de nascimento estimada do sibling imediatamente anterior. Esse procedimento foi repetido para calcular o nascimento do próximo sibling mais velho, e reiteradamente até chegarmos ao primeiro sibling. Peters e eu descrevemos em um de nossos livros como os 
padrôes biológicos e culturais de reprodução Yanomami criam um certo ritmo nos nascimentos das crianças (Early 6 Peters, 1990:37-51). O tempo médio de intervalo entre eles expressa esse ritmo.

No cálculo da extensão média dos intervalos, só entraram os nascimentos cujas datas eram exatas. Tínhamos códigos de qualidade relativos ao número de elementos conhecidos nas duas datas de nascimento que definiam o intervalo. Fundamentado neles, foi criado um código adicional para a qualidade do intervalo em si. Esse código de qualidade indicava se, em um dado intervalo, as duas datas de nascimento que o definiam eram exatas ou eram parcialmente estimadas no que diz respeito a ano, mês ou dia. Somente os intervalos definidos por duas datas exatas (ou pelo menos contendo ano e mês, para as datas posteriores a 1957) foram utilizados para calcular a média. A média foi então aplicada de modo encadeado até a última data de nascimento conhecida em determinada história reprodutiva, como mencionei anteriormente.

As características específicas dos intervalos foram também levadas em conta nas estimações?

Sim, foram. Para ter mais precisão, calculamos diversas médias para a extensão dos intervalos, dependendo do tipo de intervalo. A extensão de um intervalo pode variar em razão da presença ou ausência de mortalidade fetal ou infantil dentro de sua abrangência. Um intervalo que não contenha mortalidade fetal ou infantil entre o período de dois nascimentos nele definidos é chamado de intervalo regular. Morte fetal (abortos provocados ou espontâneos) pode prolongar a extensão de um intervalo entre dois nascimentos vivos, evidentemente, por causa do tempo de gestação. Nesse tipo de intervalo pode haver outras variaçóes sistemáticas dependendo do tipo de morte fetal. Abortos deliberados geralmente ocorrem no segundo mês de gravidez (Early $G$ Peters, 1990:76-77), ao passo que abortos espontâneos normalmente acontecem mais tarde, podendo ocorrer inclusive ao se completar a gravidez, como é o caso de natimortos. Mas eu dizia que se a morte fetal pode aumentar o intervalo, a morte de bebês (incluindo infanticídio) e de crianças pequenas de até dois anos e meio pode ter o efeito contrário. Essas mortes encurtam o intervalo, pois eliminam o processo de aleitamento, que tem efeitos contraceptivos. Isso abre a possibilidade de ocorrer uma nova gravidez mais rapidamente do que ocorreria caso a mulher tivesse continuado a amamentar a criança por dois ou três anos. $O$ resultado é um intervalo mais curto que o intervalo regular. 
Pode-se falar, entâo, de uma certa tipologia de intervalos?

De fato. Em nosso trabalho, os intervalos definidos por intermédio de datas exatas (mês e ano) foram classificados em uma ordem de extensão decrescente: 1) intervalos contendo um aborto espontâneo (ou natimorto); 2) intervalos contendo um aborto provocado; 3) intervalos regulares, não contendo mortalidade fetal ou infantil; 3 ) intervalos em que o sibling precedente morreu entre o segundo mês e os dois anos e meio de vida; 5) intervalos em que o sibling precedente morreu no primeiro mês de vida.

Todos os intervalos classificados desse modo foram então listados junto aos os nomes das crianças e das mães. Examinamos os casos de intervalos incomuns, verificando se havia como explicá-los. Em geral, intervalos extremamente curtos indicam um erro dos dados. Esses intervalos foram retirados da amostra, até que pudéssemos verificá-los ou corrigi-los. Já os intervalos muito longos indicam geralmente uma lacuna nos nascimentos, demandando uma verificação em campo. As razões para intervalos mais longos que o normal podem ser determinadas. Incluem, por exemplo, viuvez, ausência de um parceiro ou esposo por períodos extensos, e assim por diante. Tais casos também foram retirados da amostra e colocados em uma categoria à parte, denominada 'intervalos estendidos'.

Assim, a extensão média dos intervalos entre nascimentos foi calculada com base nos casos que continuaram na amostra. A média do intervalo em que ocorreu morte do bebê no primeiro mês de vida ficou em 1,9 ano. Para o intervalo em que houve morte do bebê entre o segundo e o vigésimo sétimo mês de vida, a média ficou em 2,1 anos. A média do intervalo regular foi de 3,2 anos. A média do intervalo em que aconteceu aborto foi de 3,8 anos e a de intervalo em que houve caso de natimorto ficou em 4,1 anos (Early $G$ Peters, 1990:46). Logo, a média apropriada foi aplicada à última data de nascimento conhecida dentro da história reprodutiva e, por conseguinte, de modo encadeado conforme já comentei, estimamos as datas que não tínhamos, referentes ao período pré contato.

Possivelmente as dificuldades maiores foram para o 'período pré-contato', não?

Sem dúvida. Havia histórias reprodutivas em que todos os nascimentos ocorreram antes de 1959, sem que conhecessemos. Contudo, algumas dessas histórias apresentavam uma criança do sexo feminino que posteriormente 
tornou-se, ela própria, mãe em uma história reprodutiva mais recente. Se a data de nascimento do primeiro filho dessa mulher for conhecida, podemos estimar a idade dela com base na média de idade das mulheres no primeiro parto. Desse modo, a idade dessa mulher vai constar, por estimativa, na história de vida reprodutiva em que ela aparece como criança, junto com seus siblings. Isso nos dá a primeira data na lista desse grupo de irmãos. Adicionando ou subtraindo a correta duração média dos intervalos entre os nascimentos da referida mulher e de seus irmãos mais velhos ou mais novos, todas as outras datas de nascimento são estimadas. Em nossos dados existiam pouquíssimas histórias sem pelo menos uma data de nascimento conhecida e sem que pelo menos uma das crianças do sexo feminino tivesse se tornado mãe. Nesses poucos casos, procedemos da seguinte forma: a idade de uma das crianças foi estimada pela idade relativa de uma pessoa em outra história, cuja data de nascimento era conhecida ou estimada. De um conjunto de siblings, selecionávamos um indivíduo mediante apresentação de dados de melhor qualidade para comparação com aquela pessoa. E, novamente, utilizando o cálculo em cadeia para siblings mais velhos e mais novos do indíviduo de referência, cuja idade então acabara de ser estimada, podíamos determinar todas as outras datas. É bom esclarecer que todas as datas estimadas foram confirmadas depois por intermédio de uma listagem em ordem cronológica, cuja seqüência foi verificada por diferentes Yanomami que entrevistamos. Esse procedimento de verificação permitiu que fizéssemos ainda alguns pequenos ajustes.

\section{E quanto a outros eventos demográficos, como óbitos e migração?}

Casos de morte e migração ocorridos antes de 1959 foram estimados pelas informações conhecidas sobre nascimentos imediatamente anteriores ou posteriores ao óbito em questão. Tendo determinado previamente as datas de nascimento, o método permite estimar as datas de óbito. Isso se chama método da idade relativa.

Fizemos um esforço concentrado para enumerar os casos de infanticídio durante o período pré-contato. É possível que alguns tenham escapado. Entretanto, acreditamos que a listagem é de alta qualidade. As informações foram obtidas junto a muitas mulheres Yanomami e verificadas, na medida do possível, com alguns outros Yanomami. Um dos nossos assistentes indígena na pesquisa era uma senhora Yanomami que começou a ter filhos em 1939, época em que a população feminina em idade reprodutiva era relativamente pequena, de modo que casos de gravidez e partos eram muitos bem conhecidos e conversados entre as mulheres. Além disso, conhecendo os dados sobre espaçamento 
puerperal do período, havia pouca chance de omissões de casos de infanticídio. $E$ os poucos intervalos possíveis foram cuidadosamente investigados.

As datas dos eventos demográficos nos últimos sessenta e seis anos foram divididas em quatro períodos não uniformes, determinados pela variação das condiçôes históricas, socioeconômicas e de saúde, do seguinte modo: a) 'período pré-contato', de 1930 a 1956; b) 'primeiros contatos', de 1957 a 1960; c) 'período de ligação', de 1961 a 1981; e d) 'período brasileiro', de 1982 ao final de 1995.

\section{Fale-nos sobre os dois livros publicados. Como se complementam?}

Em 1990, publicamos o primeiro volume com o resultado de nossas pesquisas (Early G Peters, 1990). O livro examina a dinâmica populacional dos Yanomami do rio Mucajaí, que, para fins das análises, foram entendidos de 1958 a 1987 como a composição de uma única população. Lançamos mão de dados etnográficos para descrever os costumes e a estrutura social relacionados a quatro variáveis demográficas básicas: fecundidade, mortalidade, imigração e emigração.

Em 2000, publicamos o segundo volume da pesquisa (Early G Peters, 2000) em que alargamos o escopo temporal da análise, adicionando a reconstrução do 'período pré-contato' (1930 a 1956) e atualizando os resultados com novos dados referentes ao período que ia desde 1988, época em que preparamos o primeiro volume, até 1995. Nesse segundo volume consideramos o grupo do Mucajaí como formado por oito populações definidas por cada uma das oito aldeias. Isso nos permitiu contemplar a variação da dinâmica populacional dentro desse grupo total. Também sintetizamos o material para o grupo inteiro.

É importante observar que esses dois livros devem ser compreendidos como um único trabalho. Inicialmente não pretendíamos publicar dois volumes; todavia, foi assim que aconteceu. Algumas pessoas, sem lerem o primeiro livro, têm a impressão errônea de que o segundo the é superior. No segundo, nós não repetimos tópicos já tratados no primeiro e que não precisavam de ser revistos. Isso vale particularmente no caso da etnografia Yanomami e na descrição de sua estrutura social. Os dois livros, no entanto, devem ser vistos como uma unidade, contendo referências recíprocas que levam de um a outro e vice-versa. Isso não foi explicado claramente no segundo volume, causando certa confusão. Idealmente, os dois livros precisariam de ser reescritos e 
publicados em um único volume em que o material fosse apresentado de maneira mais integrada.

\section{Como estão estruturados os dois livros?}

O material pode ser dividido em alguns tópicos principais. O primeiro volume e a primeira parte do segundo tratam da dinâmica populacional interna dos Mucajaí Yanomami. O segundo volume contém algumas seções adicionais. Discutindo sobre meus livros anteriores com diferentes profissionais, vi que alguns deles não entenderam certos índices demográficos. Assim sendo, no segundo livro, acrescentamos um capítulo explicando princípios básicos de demografia para que o leitor não-demógrafo pudesse melhor compreender as partes subseqüentes. Existe um outro capítulo em que fazemos uma crítica ao trabalho etnográfico de alguns antropólogos. Em uma seção adicional procuramos situar o estudo do Mucajaí num contexto mais amplo, especialmente para o entendimento do que chamamos 'período brasileiro'. Como se fossem círculos concêntricos que se expandem, abordamos outros grupos Yanomami de Roraima, mas cuja situação só poderia ser entendida em referência ao contexto nacional brasileiro que, por sua vez, tem de ser considerada no âmbito de uma perspectiva internacional. Eu não tenho a pretensão de ser especialista em todas essas áreas. Isso talvez explique algumas lacunas no texto, sobretudo a falta de referência a trabalhos brasileiros, já que para mim é difícil ler em português.

\section{Qual é o quadro geral que se apreende pelo estudo que vocês conduziram?}

Nós examinamos a dinâmica populacional dos Mucajaí Yanomami desde 1930, ano em que a população somava noventa e seis pessoas, até o início de 1996, quando eles já somavam trezentos e sessenta e uma pessoas (Figura 1). No início do século XXI, esse número já passa de quatrocentos. A Figura 2 mostra as mudanças radicais na distribuição sexo-idade sofridas pelo grupo nos últimos sessenta e seis anos, indicando alterações na estrutura populacional. Lançando mão de dados históricos, etnográficos e biológicos, esses sessenta e seis anos foram divididos em quatro períodos, como falei anteriormente, a fim de que pudéssemos analisar dinâmicas demográficas distintas. A Tabela 1 mostra, em cada período (pré-contato, primeiros contatos, ligação e brasileiro), os números absolutos e as taxas brutas das variáveis demográficas básicas, bem como a razão entre os sexos (sex-ratio) e as estratificações segundo sexo e idade. 
Figura 1 - Crescimento da população dos Mucajai Yanomami no período 1930-1996

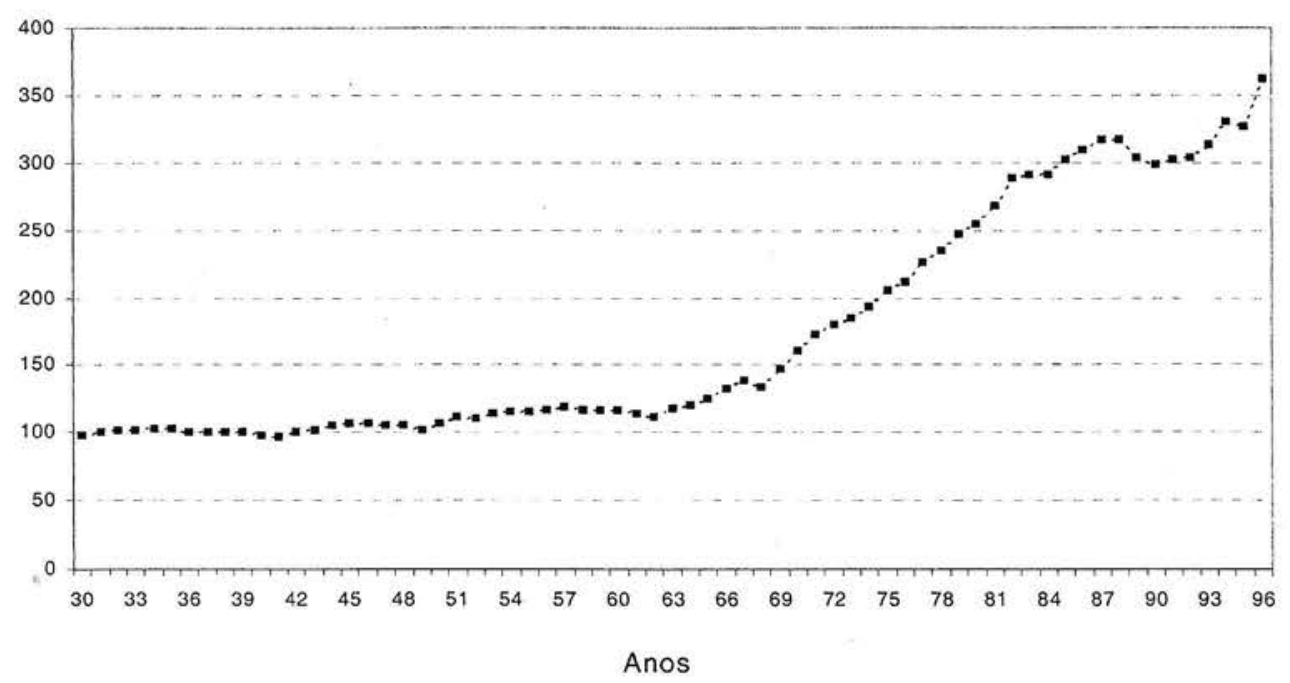

Figura 2 - Composição da população segundo sexo e idade dos Mucajaí Yanomami no período 1930-1996

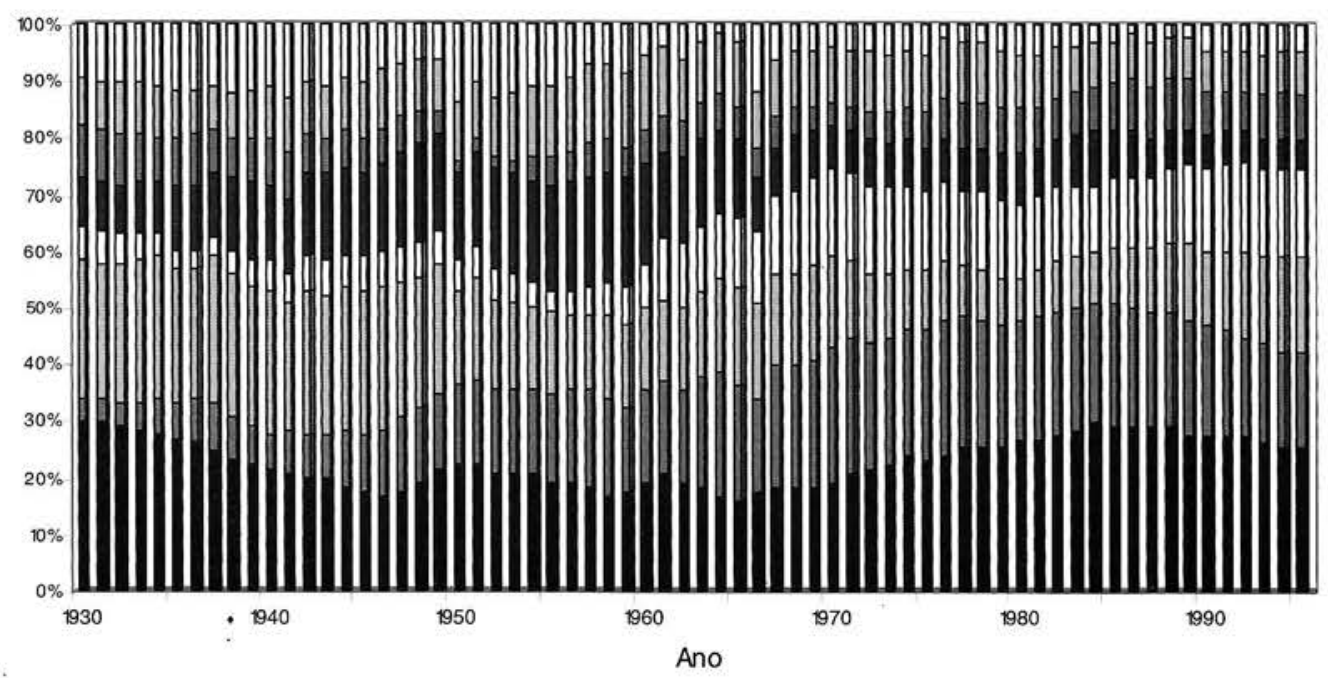

Mas. 0-15 anos $\square$ Fem. 0-15 anos $\square$ Mas. 15-30 anos $\square$ Fem. 15-30 anos

口Mas. 30-45 anos $\square$ Fem. 30-45 anos $\square$ Mas. 45+ anos $\square$ Fem. 45+ anos 
Tabela 1 - Perfil demográfico dos Mucajaí Yanomami segundo os diversos períodos entre 1930-1996

\begin{tabular}{|c|c|c|c|c|c|c|c|c|c|c|c|c|c|}
\hline & 1930 & \multicolumn{2}{|c|}{ Pré-contato } & \multirow{2}{*}{$\begin{array}{l}1957 \\
120\end{array}$} & \multicolumn{2}{|c|}{ Contato } & \multirow{2}{*}{$\frac{1961}{114}$} & \multicolumn{2}{|c|}{ Ligação } & \multirow{2}{*}{$\frac{1982}{295}$} & \multicolumn{2}{|c|}{ Brasileiro } & \multirow{2}{*}{$\frac{1996}{361}$} \\
\hline $\begin{array}{l}\text { Tamanho da } \\
\text { população }\end{array}$ & 96 & & & & & & & & & & & & \\
\hline Incremento & & & 24 & & & -6 & & & 181 & & & 66 & \\
\hline Crescimento natural & & & 16 & & & -12 & & & 135 & & & 87 & \\
\hline Nascimentos & & 79 & & & 14 & & & 201 & & & 210 & & \\
\hline Óbitos & & 63 & & & 26 & & & 66 & & & 123 & & \\
\hline Migração líquida & & & 8 & & & 6 & & & 46 & & & -21 & \\
\hline Imigrantes & & 8 & & & 6 & & & 49 & & & 21 & & \\
\hline Emigrantes & & 0 & & & 0 & & & 3 & & & 42 & & \\
\hline \multicolumn{14}{|c|}{ Taxas brutas } \\
\hline Incremento & & & 8,4 & & & $-12,8$ & & & 47.1 & & & 14,9 & \\
\hline Crescimento natural & & & 5.6 & & & $-25,6$ & & & 35.1 & & & 19,7 & \\
\hline $\begin{array}{l}\text { Taxa bruta de } \\
\text { natalidade }\end{array}$ & & 27,8 & & & 29,9 & & & 52,3 & & & 47,5 & & \\
\hline $\begin{array}{l}\text { Taxa bruta de } \\
\text { mortalidade }\end{array}$ & & 22,2 & & & 55,6 & & & 17,2 & & & 27.8 & & \\
\hline Migração líquida & & & 2,8 & & & 12,8 & & & 12.0 & & & $-4,8$ & \\
\hline Imigrantes & & 2,8 & & & 12,8 & & & 12,7 & & & 4,8 & & \\
\hline Emigrantes & & 0,0 & & & 0,0 & & & 0,0 & & & 9,5 & & \\
\hline \multicolumn{14}{|c|}{ Composição da populaçăo por sexo e idade } \\
\hline População & 96 & & & 120 & & & 114 & & & 295 & & & 361 \\
\hline Masculino & 69 & & & 78 & & & 71 & & & 159 & & & 202 \\
\hline Feminino & 27 & & & 42 & & & 43 & & & 136 & & & 159 \\
\hline$\%$ feminino & 28.1 & & & 35,0 & & & 37,7 & & & 46,1 & & & 44,0 \\
\hline$\%$ por idade e sexo & & $\% \mathrm{M}$ & $\% \mathrm{~F}$ & & $\% \mathrm{M}$ & $\% \mathrm{~F}$ & & $\% \mathrm{M}$ & $\% \mathrm{~F}$ & & $\% \mathrm{M}$ & $\% \mathrm{~F}$ & \\
\hline $0-14,9$ & & 22,6 & 9,9 & & 18,3 & 15.8 & & 22,6 & 21,7 & & 27,9 & 19,5 & \\
\hline $15-29,9$ & & 22,2 & 5,0 & & 14,4 & 6,6 & & 11.9 & 13,5 & & 13,1 & 13,6 & \\
\hline $30-44.0$ & & 14,5 & 6,2 & & 18,7 & 4,9 & & 9,6 & 4,7 & & 6.9 & 7.9 & \\
\hline $45+$ & & 9,7 & 10,0 & & 12,9 & 8.2 & & 10,2 & 4,9 & $=$ & 7,2 & 4,0 & \\
\hline Total & & 68,9 & 31,1 & & 64,4 & 35,6 & & 54,3 & 45,7 & & 55.1 & 44,9 & \\
\hline
\end{tabular}

Fale-nos sobre o 'período pré-contato'.

O que chamamos de 'pré-contato' vai de 1930 a 1956. No início de 1930, como disse, a população era de noventa e seis pessoas. Ao fim de 1957, havia passado para cento e vinte, o que corresponde a um aumento de apenas vinte e quatro indivíduos em um período de vinte e sete anos, isto é, uma taxa de crescimento 
de $0,8 \%$. A principal razão para um crescimento tão vagaroso era a taxa bruta de natalidade (27,8 por mil), baixa para uma população que não fazia uso de contraceptivos. No entanto, a taxa de fecundidade total era de 7,1, número próximo à média esperada $(8,0)$ para esse tipo de população. Isso significa que as mulheres em idade reprodutiva vinham gerando filhos dentro do padrão de normalidade. A baixa natalidade devia-se justamente ao pequeno número de mulheres em idade reprodutiva na população (apenas 11\%), à medida que numa situação de razões de sexo mais equilibrada, a porcentagem de mulheres em idade reprodutiva fica em torno de $20 \%$. Não sabemos a causa para essa baixa proporção de mulheres em idade reprodutiva. Há hipóteses sugerindo que isso se devia à preferência pelo infanticídio feminino. Sem dúvida é um fator, mas duvido que seja a causa principal.

É possível apontar para algumas das conseqüências demográficas da prática do infanticídio feminino preferencial, particularmente seus reflexos sobre os padróes de nupcialidade?

O desequilíbrio na razão entre os sexos (sex ratio) causou um problema matrimonial: poucas mulheres para muitos homens. $O$ resultado foi um aumento das uniões poliândricas, como demonstramos no primeiro livro (Early 6 Peters, 1990:103-108). Quase a metade (48\%) de todas as uniōes matrimoniais ocorridas durante a década 1950 foram de tipo poliândrico. Na maioria dos casos, irmãos desposavam a mesma mulher, isto é, poliandria fraterna. À proporção que a população restaurou o equilíbrio entre os sexos, a poliandria decresceu fortemente, dando lugar a uniões monogâmicas.

O problema tornava-se mais complicado por causa do sistema de parentesco Yanomami, com suas prescrições de casamento entre primos cruzados. Como se sabe, o casamento entre primos paralelos é proibido; o cônjuge preferencial é um primo cruzado. Numa população pequena, isso pode acabar excluindo do universo dos parceiros matrimoniais possíveis um número significativo - $e$ em muitos casos, a maioria - das pessoas do sexo oposto. É um fator cultural que pode atrasar os casamentos, gerando impacto sobre a taxa de fecundidade.

\section{Pode-se falar da manutenção de um padrão reprodutivo entre os Yanomami ao longo do tempo?}

Certamente. Mostramos no primeiro livro (Early G Peters 1990:37-51) que o padrão reprodutivo permaneceu constante ao longo dos últimos sessenta e seis anos, com mínimas exceções. 
Pensando no ciclo feminino: a primeira menstruação ocorre entre os doze, treze anos; a primeira coabitação por volta dos quatorze. A mulher tem seu primeiro parto com a idade média de 16,8 anos, caso não tenha havido anteriormente abortos ou morte fetal. A extensão média do intervalo entre os nascimentos é de 3,2 anos, desde que, novamente, não tenha havido aborto, morte fetal ou morte infantil neste intervalo. A menopausa acontece em torno dos quarenta anos. A mortalidade é moderada, apresentando taxa bruta de 16 óbitos por mil habitantes. Esse número poderia ser mais alto se houvesse maior equilíbrio na razão entre os sexos. $O$ número pequeno de mulheres prolíficas significa que há, relativamente, menos bebês na população, grupos de idade que apresentam, em geral, mortalidade alta.

\section{E quanto ao período seguinte, o chamado 'primeiros contatos'?}

De acordo com o que mencionei há pouco, chamamos de 'primeiros contatos' o período que vai de 1957 a 1960. Devo frisar que no segundo livro revisamos em parte a análise desse período publicada no volume de 1990. Foi necessário fazer uma ligeira modificação nos anos que definem o período, à medida que os dados demográficos nos levaram a aprofundar a história do grupo. No início do período, a população era de cento e vinte pessoas, caindo para cento e catorze ao fim de 1960. Uma queda de seis pessoas em quatro anos, a saber, um declínio de 1,3\%.

O principal motivo do declínio populacional foi a alta mortalidade, com uma taxa bruta de 55,6 por mil. As doenças infectocontagiosas foram a causa principal do alto nível de mortalidade. Estas últimas, por sua vez, resultaràm dos primeiros contatos que o grupo do Mucajaí manteve com outros grupos Yanomami e com os brasileiros. Não sabemos exatamente quais foram as vias de entrada das doenças, sequer se houve uma única via. $O$ fato é que, tendo começado sua busca por ferramentas de aço e bens industrializados em 1957, o grupo do Mucajaí passou a fazer diversas viagens por ano, descendo o rio para visitar fazendas de regionais brasileiros. Nessa época, também estabeleceram contato com outros grupos Yanomami vizinhos, de quem estavam afastados por quase vinte anos. Algumas dessas comunidades Yanomami já mantinham contato freqüente com os brasileiros: recebiam a visita de garimpeiros e de alguns militares. É possível que as moléstias tenham sido adquiridas por intermédio de contatos com outro grupo Yanomami que habitava um tributário do alto rio Mucajaí e mantinha contatos esporádicos com os brasileiros por uma rota de comércio ao longo do rio Catrimani. 
Outras razões influenciaram o decréscimo populacional durante esse período?

Sim, pois nesse período manteve-se baixo o número de mulheres em idade reprodutiva, o que é uma outra causa para o declínio. O nível de natalidade, cuja taxa bruta era de 30 por mil, e a taxa de imigração, da ordem de 13 por mil, foram insuficientes para compensar a alta mortalidade. Porém, a imigração consistia especialmente de mulheres em idade reprodutiva, oriundas de outras comunidades Yanomami, que vinham para se casar com homens do Mucajaí. Isso começou a reduzir o desequilíbrio entre os sexos, fato que acabaria por ter um impacto na fecundidade dos períodos posteriores.

\section{E quanto ao período seguinte, o chamado 'período de ligação'?}

O período seguinte foi de 1961 a 1981. Esses anos foram marcados por contatos intermitentes com a sociedade nacional e por contatos mais freqüentes com outros grupos Yanomami. As visitas rio abaixo aos fazendeiros ribeirinhos se intensificaram, já que alguns Mucajaí Yanomami começaram a trabalhar temporariamente nas fazendas. Ali foram familiarizando-se com a sociedade brasileira. Eventualmente, alguns deles acompanhavam os fazendeiros até a cidade de Boa Vista, e, dessa maneira, iam alargando seu horizonte e seus conhecimentos.

Durante esses vinte e um anos, a população cresceu, passando de cento e quatorze para duzentos e noventa e cinco pessoas. Uma taxa de crescimento rápida, derivada da queda na mortalidade, que passou de 55,6 (no período anterior de primeiros contatos) para 17,2 por mil. Entretanto, um fator tão importante quanto esse foi o crescimento na taxa bruta de natalidade, que passou de 28 e 29 (nos períodos anteriores, respectivamente) para 52 por mil nesta fase 'de ligação'.

O que causou a redução da mortalidade nesse período?

Foram vários os fatores. Após a devastação inicial promovida por epidemias, o grupo do Mucajaí começou a adquirir imunidade contra algumas doenças infectocontagiosas. Além disso, eles foram assistidos pelos programas de saúde dos missionários. Embora o programa consistisse apenas na manutenção de uma farmácia razoavelmente suprida, foi o suficiente para resolver várias situações médicas, muitas no estágio inicial, antes que o problema se tornasse 
grave. A farmácia era mantida por uma enfermeira treinada e possuía um equipamento de rádio capaz de contactar a cidade de Boa Vista, em caso de necessidade de atendimento. Essa enfermeira estava em contato diário com os Yanomami, não apenas na farmácia, mas interagia com eles e os visitava em suas yanos (casas). Quer dizer, essa enfermeira também estava fazendo um serviço de saúde pública, todo tempo procurando educar os Mucajaí Yanomami a respeito das doenças mais comuns e do que fazer para evitá-las e delas tratar. Outro fator importante foi o relativo isolamento do Mucajaí em relação à população brasileira de uma maneira geral. À época, os brasileiros eram possivelmente as principais fontes de contágio para os índios, mesmo que, algumas vezes, as doenças não lhes causassem tantos danos como causam aos índios. Assim, nesse período, é provável que a maioria das doenças no Mucajaí tenha sido contraída de outros grupos Yanomami que, por sua vez, estavam em contato mais próximo com a população nacional.

\section{Que fatores estiveram associados ao aumento da natalidade?}

Ele resultou tanto do aumento absoluto quanto do aumento relativo de mulheres em idade reprodutiva. Isso, por seu turno, originou-se de um equilíbrio aproximado na razão de sexo dos nascimentos ocorridos nos anos anteriores, bem como - é fundamental observar - da imigração de mulheres oriundas de outras aldeias Yanomami.

\section{$E$ a fase seguinte que vocês denominaram de 'período brasileiro'?}

Esse período vai de 1982 a 1995. Chamamos esses anos de 'período brasileiro' porque o contato com a sociedade nacional cresceu a ponto de causar um impacto significativo na demografia do Mucajaí. As temporadas fora da comunidade, quando as pessoas iam trabalhar nas fazendas e na cidade de Boa Vista, intensificaram-se bastante. Algumas dessas estadias tornaram-se permanentes, passando a contar como emigração para áreas não-indígenas. $A$ explosão do garimpo teve um sério impacto sobre o grupo, uma vez que o rio Mucajaí transformou-se uma importante hidrovia, transportando suprimentos para os tributários localizados na porção mais alta do rio. As lideranças Mucajaí começaram a participar de um movimento indígena mais amplo, regional e nacional, em defesa de seus direitos e da proteçâo de suas terras. Por volta dessa época, a Fundação Nacional do Índio (Funai) criou um posto no baixo Mucajaí para onde algumas aldeias foram realocadas. Os Mucajaí já haviam mantido contatos esporádicos com a população nacional nos períodos que chamamos de 'primeiros contatos' e 'de ligação', contudo, agora a vida nacional 
tornara-se realmente parte de suas vidas. Durante o 'período brasileiro' a população passou de duzentos e noventa e cinco para trezentos e sessenta e uma pessoas, um aumento de apenas sessenta e seis pessoas em quatorze anos, o que representa uma taxa bruta de crescimento de 14,9 por mil ou $1,5 \%$. Essa taxa é significativamente menor do que a que verificamos no período anterior, que foi de 47,1 por mil ou $4,7 \%$.

\section{Que fatores estiveram associados ao baixo crescimento nesse período?}

A principal razão foi o aumento da mortalidade gerado pelo maior contato com a sociedade nacional. As doenças continuaram a ser um problema, principalmente a malária, adquirida, sobretudo, dos garimpeiros, e a tuberculose, adquirida de outros grupos Yanomami em contato mais próximo com os brasileiros. A emigração foi outro fator que contribuiu para o declínio populacional. Nesse período, quarenta e duas pessoas deixaram a comunidade em caráter permanente. Essa foi uma alteração importante, visto que no período anterior foram apenas três pessoas. Pela primeira vez houve emigração de mulheres Mucajai para se casarem em outras aldeias. O total de casos de emigração foi grande o bastante para ultrapassar a lenta imigração, de modo que, pela primeira vez desde que começamos a pesquisa, aconteceu migração negativa. Um fator adicional para o decréscimo foi uma pequena queda na fecundidade. A queda pode ser uma variação estatística, pois os números são pequenos. A idade de coabitação parece estar aumentando, por razões que ainda não sabemos bem quais são. Talvez isso se deva ao maior tempo de permanência fora da área indígena, para fins de trabalho.

Seria possível resumir as principais características demográficas de cada um dos períodos?

No 'período pré-contato', o crescimento populacional foi pequeno particularmente em virtude da falta de mulheres em idade reprodutiva, com um agravante, qual seja, o sistema de casamento de primos cruzados. Isso representou um risco para a sobrevivência demográfica do grupo, que era rełativamente pequeno.

A população decresceu no 'período dos primeiros contatos' em função da alta mortalidade gerada pelas doenças infectocontagiosas, para as quais o grupo, por muito tempo isolado, não tinha imunidade. Esse é um padrão comum em 
situação de contato inicial. A baixa fecundidade e a imigração foram insuficientes para contrabalançar a alta mortalidade.

No 'período de ligação', houve um rápido crescimento populacional em razão da interação de todas as variáveis demográficas. Ocorreu uma queda significativa da mortalidade, um crescimento igualmente significativo da natalidade, acompanhado de uma taxa moderada de imigração e de emigração mínima.

Finalmente, no 'período brasileiro' também aconteceu um aumento populacional; porém, muito mais lento do que no período precedente. Houve um aumento considerável da mortalidade e da emigração. Esses fatores, juntamente com uma ligeira queda na fecundidade e com uma diminuição da taxa de imigração, redundaram numa desaceleração do crescimento em relação ao período anterior.

Um tópico importante na literatura sobre demografia dos povos indígenas diz respeito ao infanticídio. Qual a contribuição das pesquisas de vocês para esse tópico?

É verdade. Falamos sobre a taxa de mortalidade dos períodos anteriores, sem que eu aprofundasse a questão do infanticídio. Vários antropólogos, sobretudo os norte-americanos, escreveram sobre a ocorrência de infanticídio entre os Yanomami. Nenhuma dessas descrições tem fundamento em dados demográficos confiáveis.

Pois bem, nossa pesquisa traz uma série de dados sobre infanticídio. De fato, o infanticídio existe. Os Yanomami consideram-no um aborto terminal e não um homicídio. Duas questões aparecem na discussão do infanticídio: suas causas e seu impacto sobre a taxa de mortalidade infantil e sobre a mortalidade de maneira geral. A Tabela 2 mostra a ocorrência de infanticídio e suas diversas causas durante os quatro períodos históricos que pesquisamos. São ocasiões, grande parte das vezes, em que há rejeição do bebê, independente do sexo. 
Tabela 2 - Freqüências e porcentagens de infanticído por período, sexo e razão

\begin{tabular}{|c|c|c|c|c|c|c|c|c|c|c|c|c|c|c|c|}
\hline & \multicolumn{3}{|c|}{$\begin{array}{l}\text { Pré-contato } \\
(1930-1956)\end{array}$} & \multicolumn{3}{|c|}{$\begin{array}{c}\text { Contato } \\
(1957-1960)\end{array}$} & \multicolumn{3}{|c|}{$\begin{array}{c}\text { Ligação } \\
(1961-1981)\end{array}$} & \multicolumn{3}{|c|}{$\begin{array}{c}\text { Brasileiro } \\
(1982-1995)\end{array}$} & \multicolumn{3}{|c|}{ Total } \\
\hline & $\mathrm{T}$ & $\mathrm{M}$ & $\mathrm{F}$ & $\mathrm{T}$ & M & $\mathrm{F}$ & $\mathrm{T}$ & $\mathrm{M}$ & $\mathrm{F}$ & $\mathrm{T}$ & $\mathrm{M}$ & $\mathrm{F}$ & $\mathrm{T}$ & $\mathrm{M}$ & $\mathrm{F}$ \\
\hline $\begin{array}{l}\text { N. de } \\
\text { infanticídios }\end{array}$ & 13 & 2 & 11 & 1 & - & 1 & 13 & 4 & 9 & 17 & 7 & 10 & 44 & 13 & 31 \\
\hline \multicolumn{16}{|c|}{ Razão (M e F) } \\
\hline Intervalo & - & - & - & - & - & - & 2 & - & 2 & - & - & - & 2 & - & 2 \\
\hline Deformidade & - & - & - & - & - & - & 1 & - & 1 & 5 & 3 & 2 & 6 & 3 & 3 \\
\hline $\begin{array}{l}\text { Falta de } \\
\text { suporte }\end{array}$ & 4 & 1 & 3 & - & - & - & 6 & 3 & 3 & 3 & 1 & 2 & 13 & 5 & 8 \\
\hline Desconhecida & 2 & 1 & 1 & - & - & - & 2 & 1 & 1 & 5 & 3 & 2 & 9 & 5 & 4 \\
\hline \multicolumn{16}{|c|}{ Razão - somente F } \\
\hline $\begin{array}{l}\text { Este } \\
\text { nascimento }\end{array}$ & 3 & - & 3 & 1 & - & 1 & 2 & - & 2 & 4 & - & 4 & 10 & - & 10 \\
\hline $\begin{array}{l}\text { Qualquer } \\
\text { nascimento }\end{array}$ & 4 & - & 4 & - & - & - & - & - & - & - & - & - & 4 & - & 4 \\
\hline \multicolumn{16}{|c|}{ Porcentagens } \\
\hline Infanticídios & 100 & 16 & 84 & 100 & - & 100 & 100 & 31 & 69 & 100 & 41 & 59 & 100 & 30 & 70 \\
\hline $\begin{array}{l}\text { Todas as } \\
\text { razōes }\end{array}$ & 100 & 100 & 100 & 100 & - & 100 & 100 & 100 & 100 & 100 & 100 & 100 & 100 & 100 & 100 \\
\hline \multicolumn{16}{|c|}{$\mathrm{M}$ ou $\mathrm{F}$} \\
\hline Intervalo & - & - & - & - & - & - & 15 & - & 22 & - & - & - & 5 & - & 6 \\
\hline Deformidade & - & - & - & - & - & - & 8 & - & 11 & 29 & 43 & 20 & 14 & 23 & 10 \\
\hline $\begin{array}{l}\text { Falta de } \\
\text { suporte }\end{array}$ & 31 & 50 & 27 & - & - & - & 46 & 75 & 33 & 18 & 14 & 20 & 30 & 38 & 26 \\
\hline Desconhecida & 15 & 50 & 16 & - & - & - & 15 & 25 & 11 & 29 & 43 & 20 & 20 & 38 & 13 \\
\hline \multicolumn{16}{|c|}{ Somente F } \\
\hline $\begin{array}{l}\text { Para este } \\
\text { nascimento }\end{array}$ & 23 & - & 18 & - & - & - & 15 & - & 22 & 24 & - & 40 & 23 & - & 32 \\
\hline $\begin{array}{l}\text { Qualquer } \\
\text { nascimento F }\end{array}$ & 31 & - & 36 & - & - & - & - & - & - & - & - & - & 9 & - & 13 \\
\hline
\end{tabular}

\section{O que explicaria tais rejeições?}

O espaçamento, vale dizer, o tempo entre o nascimento de um filho e outro, pode ser um problema para os Yanomami por causa da necessidade de amamentação. A fonte básica de alimento de um bebê Yanomami é o leite materno. Isso faz com que uma criança careça de ser amamentada até seus dois anos, pelo menos. Por conseguinte, como muitos outros povos indígenas, os:Yanomami entendem que o leite materno é limitado, ou seja, uma mulher só pode amamentar adequadamente um filho por vez. Portanto, é claro que, ocorrendo um novo processo de gravidez e parto pouco tempo depois do nascimento da criança lactente, o novo bebê estaria competindo com o primeiro pelo leite da mãe. Nesses casos, sobre os quais escrevemos no primeiro livro (Early G Peters, 1990:77), é comum que a gravidez seja interrompida no segundo 
mês. Mas, se por qualquer motivo o aborto não acontece nessa etapa, a atitude adotada imediatamente após o parto será o infanticídio. No caso de gêmeos, pela mesma razão, um dos bebês será rejeitado. Em geral, a măe fica com o bebê do sexo masculino ou com o que the parecer mais forte e saudável.

Problemas relacionados ao sustento da criança também são fatores importantes. Uma criança rejeitada caso uma mulher imagine que não pode contar com um homem para sustentá-la. Isso se aplica a diversas situaçōes. Por exemplo, se a continuação do casamento for incerta, um novo bebê - ou recém-nascido nāo será desejado. Mulheres viúvas que engravidam também podem vir a cometer infanticídio. Quando o pai reconhecido do bebê não é o marido da mãe ou quando um casal se separa antes do nascimento da criança, também pode levar ao infanticídio. Além disso, qualquer deformidade física resulta em infanticídio, inclusive aquelas que considerariamos insignificantes, como membranas interdigitais, por exemplo. A deformidade é vista como maldição e a criança é rejeitada.

E quanto ao infanticídio preferencialmente direcionado para as crianças do sexo feminino?

Normalmente, isso acontece quando o casal já tem muitas filhas e deseja um menino. Se a próxima criança a nascer for uma menina, pode ser rejeitada para que a mãe possa engravidar rapidamente de novo, na expectativa de um menino. Temos uma história de vida reprodutiva que ilustra bem essa estratégia. $E$ a de uma família com três casos de infanticídio feminino. A seqüência de nascimento dos filhos ( $M$ indica um menino, $F$ uma menina e $I$ um infanticídio) foi a seguinte: $F, M, M, F, F, F, F-I, M, F-I, M, F-I, F$. Algumas famílias desejam que o primeiro filho seja do sexo masculino e rejeitam as meninas em todo esse estágio, até que venha o menino. Enfim, essas são as situaçôes mais comuns de infanticídio preferencial feminino entre os Yanomami. Năo há uma rejeição sistemática a todos os bebês do sexo feminino. No conjunto de dados que obtivemos, só aparecem duas familias que rejeitavam todas as meninas, em face de um desejo de fortalecer suas condições de subsistência.

\section{Foi possível estimar o impacto do infanticídio preferencial de meninas na mortalidade geral?}

Sim, procuramos avaliar esse impacto na mortalidade geral. A questão envolve diversos níveis de classificação de mortalidade, alguns que utilizamos pouco 
por falta de dados. De forma preliminar, fizemos uma decomposição da mortalidade geral e infantil em algumas categorias. Com isso, podemos analisar a contribuição do infanticídio para a estrutura de mortalidade global. Consideremos o Diagrama 1. Começando pela esquerda (com a mortalidade total) e prosseguindo pelo ramo superior, a Tabela 3 formula questões cada vez mais especificas sobre a mortalidade. $O$ ramo inferior traz as categorias residuais que esclarecem a respeito do que se excluiu do ramo superior. Complementando, a Tabela 3 mostra o impacto do infanticídio sobre diversos números e taxas de mortalidade: óbitos infantis, óbitos totais, taxa bruta de mortalidade e taxa de mortalidade infantil. Os missionários relataram somente quatro casos em que sua intervenção evitou o infanticídio. Isto é, a presença missionária não teve nenhuma influência importante nesses números.

Diagrama 1 - Esquema de análise dos óbitos por infanticídio no conjunto geral dos óbitos

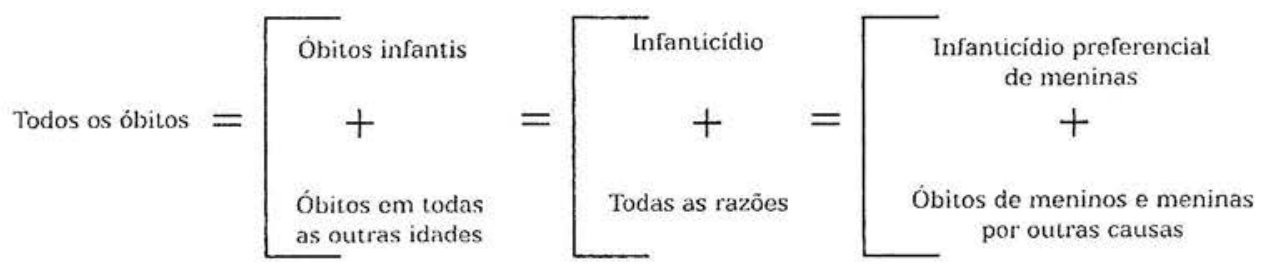

Fale-nos sobre a distribuição espacial das comunidades.

No decorrer dos sessenta e seis anos cobertos pela pesquisa, existiram oito aldeias Mucajaí Yanomami. Nós analisamos a dinâmica populacional de cada aldeia, procurando entender a diferenciação demográfica interna ao grupo como um todo. Os resultados foram publicados em nosso segundo livro (Early $G$ Peters, 2000:101-190). É importante levar em consideração as dimensôes diferenciais de população de cada aldeia em particular, por causa de seu impacto sobre o perfil demográfico geral do grupo, como discutimos há pouco. Quanto maior o tamanho populacional de uma aldeia em relação às outras, maior será seu impacto. A Tabela 4 mostra as dimensões populacionais das oito aldeias e a contribuição porcentual de cada uma para o conjunto populacional tomado em bloco. 
Tabela 3 - Infanticídio entre os Mucajaí em vários períodos e sua relação com outros parâmetros demográficos

\begin{tabular}{|c|c|c|c|c|c|}
\hline & $\begin{array}{l}\text { Pré-contato } \\
(1930-1956)\end{array}$ & $\begin{array}{c}\text { Contato } \\
(1957-1960)\end{array}$ & $\begin{array}{c}\text { Ligação } \\
(1961-1981)\end{array}$ & $\begin{array}{c}\text { Brasileiro } \\
(1982-1995)\end{array}$ & Total \\
\hline \multicolumn{6}{|c|}{ I. Números absolutos } \\
\hline 1. Todos os óbitos & 63 & 26 & 66 & 123 & 278 \\
\hline 2. Óbitos infantis & 14 & 2 & 26 & 42 & 84 \\
\hline 3. Casos de infanticídio & 13 & 1 & 13 & 17 & 44 \\
\hline $\begin{array}{l}\text { 4. Infanticídio preferencial } \\
\text { feminino (IPF) }\end{array}$ & 7 & 1 & 2 & 4 & 14 \\
\hline 5. Nascidos vivos & 79 & 14 & 201 & 210 & 504 \\
\hline 6. Pessoa-ano & 2843 & 468 & 3844 & 4420 & 11574 \\
\hline \multicolumn{6}{|c|}{ II. Composição porcentual dos infanticídios } \\
\hline 7. $\operatorname{IPF}(4 / 3)^{*}$ & 53.8 & 100 & 15,4 & 23,5 & 31,8 \\
\hline 8. Outros $(100 \%-7)$ & 46,2 & - & 84,6 & 76,5 & 68,2 \\
\hline \multicolumn{6}{|c|}{ III. Composição porcentual dos óbitos em crianças } \\
\hline 9. Infanticídio $(3 / 2)$ & 92.9 & 50,0 & 50.0 & 40.5 & 52,4 \\
\hline 10. IPF $(4 / 2)$ & 50,0 & 50.0 & 7.7 & 9,5 & 16.7 \\
\hline \multicolumn{6}{|c|}{ IV. Composição porcentual do total de óbitos } \\
\hline 11. Óbitos de crianças (2/1) & 22,2 & 7.7 & 39,4 & 34.1 & 30,2 \\
\hline 12. Infanticídio $(3 / 1)$ & 20,5 & 0,8 & 19.7 & 13.8 & 15,8 \\
\hline 13. IPF $(4 / 1)$ & 11.1 & 3,8 & 3.0 & 3,3 & 5,0 \\
\hline \multicolumn{6}{|c|}{ V. Alguns componentes da taxa bruta de mortal. (TBM) } \\
\hline 14. Taxa bruta de mortalidade $(1 / 6)$ & 22.2 & 55.6 & 17.2 & 27.8 & 24,0 \\
\hline 15. Devido a óbitos em crianças (2/6) & 4,9 & 4,3 & 6,8 & 9,5 & 7,3 \\
\hline 16. Devido a infanticídio $(3 / 6)$ & 4,6 & 2,1 & 3.4 & 3,8 & 3,8 \\
\hline 17. Devido a IPF (4/6) & 2.5 & 2,1 & 0.5 & 0.9 & 1,2 \\
\hline $\begin{array}{l}\text { 18. Porcentagem da TBM devido a IPF } \\
(17 / 14)\end{array}$ & 11,1 & 3,8 & 3.0 & 3,3 & 5,0 \\
\hline \multicolumn{6}{|c|}{ VI. Alguns componentes da taxa de mortalidade infantil } \\
\hline 19. Taxa de mortalidade infantil $(2 / 5)$ & 177,2 & 142,9 & 129,4 & 200,0 & 166,7 \\
\hline 20. Devido a infanticídio $(3 / 5)$ & 164.6 & 71.4 & 64,7 & 81,0 & 87.3 \\
\hline 21. Devido a IPF $(4 / 5)$ & 88,6 & 71,4 & 10,0 & 19.0 & 27,8 \\
\hline \multicolumn{6}{|c|}{ VII. Razões de sexo hipotéticas } \\
\hline $\begin{array}{l}\text { 22. Razão de sexo no nascimento } \\
\text { (RSN) }\end{array}$ & 48,1 & 50,0 & 48,3 & 44,8 & 46,3 \\
\hline 23. RSN, removendo infanticídio $(5-3)$ & 40.9 & 46.2 & 46.8 & 45.9 & 45,6 \\
\hline 24. RSN, removendo IPF $(5-4)$ & 43,1 & 46,2 & 47,7 & 43,7 & 45,3 \\
\hline
\end{tabular}

Obs.: Os números entre parênteses indicam as linhas nas quais estão localizadas os valores utilizados nos cálculos. Por exemplo, os valores da linha 7 foram obtidos pelo quociente dos valores da linha 4 pela linha 3. 
Tabela 4 - População total (P) e pessoas-ano (PA) das aldeias Xilixana em diferentes períodos

\begin{tabular}{|c|c|c|c|c|c|c|c|c|c|c|}
\hline \multicolumn{11}{|c|}{ População (P) e pessoas-ano (PA) } \\
\hline & & 1930 & Pré-contato & 1957 & Contato & 1961 & Ligação & 1982 & Brasileiro & 1996 \\
\hline Grupo & $P$ & 96 & & 120 & & 114 & & 295 & & 361 \\
\hline aldeias & $\mathrm{PA}$ & & 2843 & & 468 & & 3844 & & 4420 & \\
\hline \multirow[t]{2}{*}{ A } & $P$ & 11 & & 17 & & - & & - & & - \\
\hline & $\mathrm{PA}$ & & 398 & & 9 & & - & & - & \\
\hline \multirow[t]{2}{*}{ B } & $\mathrm{P}$ & 33 & & 21 & & 28 & & 65 & & 37 \\
\hline & $\mathrm{PA}$ & & 758 & & 118 & & 923 & & 663 & \\
\hline \multirow[t]{2}{*}{ C } & $P$ & 52 & & 82 & & 38 & & 107 & & 47 \\
\hline & $\mathrm{PA}$ & & 1687 & & 316 & & 1300 & & 774 & \\
\hline \multirow[t]{2}{*}{ D } & $P$ & - & & - & & 48 & & 73 & & 57 \\
\hline & $\mathrm{PA}$ & & - & & 26 & & 1076 & & 929 & \\
\hline \multirow[t]{2}{*}{$\mathrm{E}$} & $\mathbf{P}$ & - & & - & & - & & 50 & & 71 \\
\hline & $\mathrm{PA}$ & & - & & - & & 545 & & 865 & \\
\hline \multirow[t]{2}{*}{$\mathrm{F}$} & $P$ & - & & - & & - & & - & & - \\
\hline & $\mathrm{PA}$ & & - & & - & & - & & 87 & \\
\hline \multirow[t]{2}{*}{ G } & $\mathrm{P}$ & - & & - & & - & & - & & 94 \\
\hline & PA & & - & & - & & - & & 729 & \\
\hline \multirow[t]{2}{*}{$\mathrm{H}$} & $P$ & - & & - & & - & & - & & 55 \\
\hline & $\mathrm{PA}$ & & - & & - & & - & & 374 & \\
\hline \multicolumn{11}{|c|}{ Tamanho da população e pessoas-ano como \% da população do grupo de aldeias } \\
\hline Grupo & $\mathrm{P}$ & $100 \%$ & & $100 \%$ & & $100 \%$ & & $100 \%$ & & $100 \%$ \\
\hline aldeias & $\mathrm{PA}$ & & $100 \%$ & & $100 \%$ & & $100 \%$ & & $100 \%$ & \\
\hline \multirow[t]{2}{*}{ A } & $\mathbf{P}$ & $11,5 \%$ & & $14,2 \%$ & & - & & - & & - \\
\hline & PA & & $14,0 \%$ & & $1,9 \%$ & & - & & - & \\
\hline \multirow[t]{2}{*}{ B } & $P$ & $34,4 \%$ & & $17,5 \%$ & & $24,6 \%$ & & $22.0 \%$ & & $10,2 \%$ \\
\hline & PA & & $26.7 \%$ & & $25.4 \%$ & & $24,0 \%$ & & $15,0 \%$ & \\
\hline \multirow[t]{2}{*}{ C } & $\mathrm{P}$ & $54,2 \%$ & & $68.3 \%$ & & $33,3 \%$ & & $36,3 \%$ & & $13,0 \%$ \\
\hline & $\mathrm{PA}$ & & $59,3 \%$ & & $67.5 \%$ & & $33,8 \%$ & & $17,5 \%$ & \\
\hline \multirow[t]{2}{*}{ D } & $P$ & - & & - & & $42,1 \%$ & & $24,7 \%$ & & $15,8 \%$ \\
\hline & $\mathrm{PA}$ & & - & & $5.6 \%$ & & $28,0 \%$ & & $21,0 \%$ & \\
\hline \multirow[t]{2}{*}{$E$} & $\mathbf{P}$ & - & & - & & - & & $16.9 \%$ & & $19.7 \%$ \\
\hline & $\mathrm{PA}$ & & - & & - & & $14.0 \%$ & & $19,6 \%$ & \\
\hline \multirow[t]{2}{*}{$\mathrm{F}$} & $\dot{\mathrm{P}}$ & - & & - & & - & & - & & - \\
\hline & $\mathrm{PA}$ & & - & & - & & - & & $2.0 \%$ & \\
\hline \multirow[t]{2}{*}{ G } & $P$ & - & & - & & - & & - & & $26,0 \%$ \\
\hline & $\mathrm{PA}$ & & - & & - & & - & & $16,5 \%$ & \\
\hline \multirow[t]{2}{*}{$\mathrm{H}$} & $\mathrm{P}$ & - & & - & & - & & - & & $15,2 \%$ \\
\hline & $\mathrm{PA}$ & & - & & - & & - & & $8.5 \%$ & \\
\hline
\end{tabular}


Como variaram essas comunidades ao longo das várias fases, incluindo as relações entre elas?

Nos períodos 'pré-contato' e 'primeiros contatos', a aldeia $C$ exercia um claro domínio sobre as duas outras que compunham o grupo. A aldeia $A$ teve um período de mortalidade alta após uma viagem durante a qual seus habitantes desceram o rio, no ano de 1957. A taxa bruta foi de 227 por mil nesse período. De saída, já era uma aldeia pequena. E com a alta mortalidade, o resultado foi a dispersão e posterior fusão com a aldeia B. Após cerca de um ano, a aldeia $B$ também sofreu uma alta de mortalidade, com uma taxa bruta de 114 por mil. Nessa mesma época, a aldeia C tinha uma taxa bruta de apenas 28 por mil, equivale dizer que nāo sofreu alta de mortalidade. Por contribuir com uma porcentagem muito maior do total da população, os baixos níveis de mortalidade de $C$ em relação aos das outras duas aldeias puxaram para baixo a taxa de mortalidade do grupo como um todo. Logo, a análise global da população, somando as três aldeias, mascara a grave crise demográfica que acometia individualmente as aldeias $A$ e $B$. O mistério é saber por que não houve tantas baixas na aldeia $C$. Enfim, este é um exemplo de como a análise de cada aldeia individualmente é capaz de iluminar as dinâmicas diferenciais de população dentro do grupo.

Depois de tantos anos trabalhando na demografia dos Yanomami, como você avalia seu próprio trabalho e como vê o futuro dessa sociedade?

A pesquisa com os Mucajaí Yanomami foi única em muitos aspectos. Conseguimos compilar dados para análise de um período de sessenta e seis anos, incluindo vinte e oito anos que antecederam ao primeiro contato do grupo com o mundo exterior. Além disso, mesmo tendo trabalhado com um grupo não-letrado, cujo sistema de contagem é elementar, conseguimos determinar a idade em que ocorreram os eventos demográficos na vida de cada indivíduo da amostra. Sabendo que a idade é uma variável fundamental para a análise demográfica, isso nos abriu o caminho para o entendimento da dinâmica populacional.

Os Mucajaí Yanomami, que eram noventa e seis pessoas em 1930, passaram a trezentos e sessenta e uma ao final de 1995. Vale dizer, um crescimento de 265 pessoas em sessenta e seis anos, o que corresponde a uma taxa bruta de 2,6\%. No alvorecer do século XXI eles já somam mais de quatrocentos. Os Mucajaí Yanomami são um exemplo histórico das teses de Gomes sobre "a virada demográfica" (Gomes, 2000), fenômeno que se contrapõe à visão pessimista 
de Darcy Ribeiro (1967:86-87) sobre o resultado do contato indígena com a sociedade nacional. Do ponto de vista metodológico, nosso trabalho mostrou que a combinação de dados históricos, etnográficos e demográficos resulta em uma análise mais fina e profunda.

Quanto ao futuro dos Yanomami, particularmente do grupo que denominamos Mucajaí (apesar de algumas aldeias não estarem mais situadas nesse rio), penso que é preciso fazer uma distinção. Tomando os indicativos de crescimento populacional, acredito que eles irão sobreviver. No entanto, avalio que a questão mais importante é saber sob que condições eles irão sobreviver. Serão capazes de manter suas terras e seus direitos, ou os interesses de empresas mineradoras internacionais irão conseguir usurpar suas áreas, condenando os Yanomami a uma situação de campesinato empobrecido e péssimas condições de saúde? Os direitos humanos dos Yanomami serão respeitados?

Considerando as lições aprendidas do passado, eu diria que o prognóstico é sombrio. Se os Yanomami perderem suas terras, sua base econômica e sua autonomia, estarão fadados a perder também uma parte significativa de sua cultura.

Agradecimentos

John Early gostaria de expressar seu agradecimento à Associação Brasileira de Estudos Populacionais (Abep) e ao Fundo para Populações das Nações Unidas (Fnuap), por terem possibilitado a participação no seminário 'Demografia dos Povos Indígenas no Brasil', realizado em São Paulo em novembro de 2003. Também à Heloísa Pagliaro, que cuidou de todo o planejamento relativo à sua viagem ao Brasil. Os organizadores agradecem a Cesar Gordon, que preparou a tradução do inglês para o português.

Referências Bibliográficas

EARLY, J. D. The Demographic Structure and Evolution of a Peasant System: the Guatemalan Population. Gainesville: University Press of Florida, 1982.

EARLY, J. D. La Estructura y Evolución Demográfica de un Sistema Campesino: La Población de Guatemala con un prólogo por Ricardo Falla. (Serie Monográfica,11) South Woodstock: Plumsock Mesoamerican Studies/ CIRMA, 2000. 
EARLY, J. D. G HEADLAND, T. N. Population Dynamics of a Philippine Rain Forest People. Gainesville: University Press of Florida, 1998.

EARLY, J. D. G PETERS, J. F. The Population Dynamics of the Mucajai Yanomama. San Diego: Academic Press, 1990.

EARLY, J. D. G PETERS, J. F. The Xilixana Yanomami of the Amazon. Gainesville: University Press of Florida, 2000.

GOMES, M. P., 2000. The Indians and Brazil. Gainesville: University Press of Florida.

RIBEIRO, D., 1967. Indigenous cultures and languages of Brazil. In: HOPPER, J. (Trad. e Org.) Indians of Brazil in the Twentieth Century. Publication N. 2. Washington, D.C.: Institute for Cultural Research Studies. p.77-165. 
Formato: $21 \times 26 \mathrm{~cm}$

Tipologia: Egyptian 505 BT/Baker Signet BT

Papel: Print Max $90 \mathrm{~g} / \mathrm{m}^{2}$ (miolo)

Cartão Supremo $250 \mathrm{~g} / \mathrm{m}^{2}$ (capa)

Fotolitos: Laser vegetal (miolo)

Ace Digital Ltda. (capa)

Impressão e acabamento: Armazém das Letras Gráfica e Editora Ltda. Rio de Janeiro, julho de 2005.

Não encontrando nossos títulos em livrarias, contactar a EDITORA FIOCRUZ:

Av. Brasil, 4036 - 1 andar - sala 112 - Manguinhos

2.1040-361 - Rio de Janeiro - RJ

Tel.: (21) 3882-9039 e 3882-9041

Telefax: (21) 3882-9006

e-mail: editora@fiocruz.br

http://www.fiocruz.br/editora 